Florida International University FIU Digital Commons

FIU Electronic Theses and Dissertations

University Graduate School

3-23-2018

\title{
Drivers and Mechanisms of Peat Collapse in Coastal Wetlands
}

Benjamin J. Wilson

Florida International University, bwils034@fiu.edu

DOI: $10.25148 /$ etd.FIDC004082

Follow this and additional works at: https://digitalcommons.fiu.edu/etd

Part of the Biology Commons, Ecology and Evolutionary Biology Commons, Marine Biology Commons, and the Plant Biology Commons

\section{Recommended Citation}

Wilson, Benjamin J., "Drivers and Mechanisms of Peat Collapse in Coastal Wetlands" (2018). FIU Electronic Theses and Dissertations. 3718.

https://digitalcommons.fiu.edu/etd/3718

This work is brought to you for free and open access by the University Graduate School at FIU Digital Commons. It has been accepted for inclusion in FIU Electronic Theses and Dissertations by an authorized administrator of FIU Digital Commons. For more information, please contact dcc@fiu.edu. 


\title{
FLORIDA INTERNATIONAL UNIVERSITY
}

Miami, Florida

\section{DRIVERS AND MECHANISMS OF PEAT COLLAPSE IN COASTAL WETLANDS}

\author{
A dissertation submitted in partial fulfillment of \\ the requirements for the degree of \\ DOCTOR OF PHILOSOPHY \\ in \\ BIOLOGY \\ by
}

Benjamin J. Wilson

2018 
To: Dean Michael R. Heithaus

College of Arts, Sciences and Education

This dissertation, written by Benjamin J. Wilson, and entitled Drivers and Mechanisms of Peat Collapse in Coastal Wetlands, having been approved in respect to style and intellectual content, is referred to you for judgment.

We have read this dissertation and recommend that it be approved.

John Kominoski

Steven Oberbauer

Leonard Scinto

Jennifer Richards, Co-Major Professor

Tiffany Troxler, Co-Major Professor

Date of Defense: March 23, 2018

The dissertation of Benjamin J. Wilson is approved.

Dean Michael R. Heithaus

College of Arts, Sciences and Education

Andrés G. Gil

Vice President for Research and Economic Development and Dean of the University Graduate School

Florida International University, 2018 
C Copyright 2018 by Benjamin J. Wilson All rights reserved. 


\section{ACKNOWLEDGMENTS}

It's been a long journey, and there are many people to thank who helped me get to this point. I would like to first and foremost thank my two wonderful advisors, Dr. Tiffany Troxler and Dr. Jennifer Richards, for taking a chance on me and allowing me the freedom to craft my research. Their constant guidance and feedback helped develop not only this dissertation but my character as well. I want to especially thank one member of my committee, Dr. John Kominoski. John took me into his lab from day one and has contributed immensely to my growth as a scientist. Long discussions with John and constant feedback from him accelerated the advancement of my work. I would also like to that the members of my committee: Dr. Steve Oberbauer and Dr. Len Scinto. Without their helpful comments on my project and use of their instruments, I would not have been able to complete my dissertation. A one last special shout out to my unofficial committee member, Dr. Evelyn Gaiser. Evelyn's constant positivity and insights guided so much of my research and decisions.

There are a few graduate students who I have been working closely with during my time at FIU: Sean Charles, Viviana Mazzei, Nick Schulte, and Shelby Servais. We all started at the same time and have been providing each other with project guidance, emotional support, and an ear to voice endless rants. It is their motivation that has kept me going. Long conversations in the lab had led to many new research insights.

The research I conducted was part of a very large collaborative effort among many organizations, and it would impossible for me to not thank them. I want to thank Dr. Steve Davis at the Everglades Foundation; Dr. Fred Sklar, Dr. Carlos Coronado, Steve Kelly, and Joe Stachelek at the South Florida Water Management District; and Dr. 
Dave Rudnick at Everglades National Park. Through monthly strategy calls, many inperson meetings, lots of long field days, and written feedback, these people provided the framework to get this research done.

I want to thank all the help I've received in both the lab and the field from the Troxler lab: Shawn Abrahams, Laura Bauman, Dr. Edward Castaneda, Marbelys Garriga, Adam Hines, Rowan Johnson, Oliver Ljustina, Melinda Martinez, Chris Sillivan, Emily Standen, Ryan Stolee, Geoff Szafranski, and Mary Grace Thibault. You guys are the underappreciated workhorses that get research done!

I want to thank all of the other graduate students and friends that I met along the way. Our chats over beers, on the beach, and around the BBQ helped me stay sane enough to finish: Josh Allen, Claire Burgett, Dr. Ross Boucek, Dr. Mike Bush, Dr. Justin Cummings, Belén Fadrique, Carissa Gervasi, Brittany Harris, Greg Hill, Jason Howard, Lukas Lamb-Wotton, Cristina Lebròn, Dr. Dong Yoon Lee, Luke Linhoff, Chris Lopes, Ximena Mesa, Nico Sebesta, Matt Smith, James Stroud, Dr. Kristie Wendelberger, and Daniel Virden.

Funding for this research came from many sources. The majority of this work was supported by Florida Sea Grant R/C-S-56 and the Florida Coastal Everglades Long Term Ecological Research Program (NSF DEB-1237517). Support for chapter IV came from the National Science Foundation Doctoral Dissertation Improvement Grant (DEB1701763). I was funded by a Florida International University Graduate Teaching Assistantship, FIU Dissertation Year Fellowship, and on research assistantships through the Florida Sea Grant and FCE LTER. 
Finally, I would like to thank my family for all the love and nurturing they have given me to reach this point. Special shout out to my Mom's care packages. Thanks Michele, Scott, Nick, Jon, and Sophie. 
ABSTRACT OF THE DISSERTATION

DRIVERS AND MECHANISMS OF PEAT COLLAPSE IN COASTAL WETLANDS by

\author{
Benjamin J. Wilson
}

Florida International University, 2018

Miami, Florida

\title{
Professor Jennifer Richards, co-Major Professor \\ Professor Tiffany Troxler, co-Major Professor
}

Coastal wetlands store immense amounts of carbon (C) in vegetation and sediments, but this store of C is under threat from climate change. Accelerated sea level rise (SLR), which leads to saltwater intrusion, and more frequent periods of droughts will both impact biogeochemical cycling in wetlands. Coastal peat marshes are especially susceptible to saltwater intrusion and changes in water depth, but little is known about how exposure to salinity affects organic matter accumulation and peat stability. I investigated freshwater and brackish marsh responses to elevated salinity, greater inundation, drought, and increased nutrient loading. Elevated salinity pulses in a brackish marsh increased $\mathrm{CO}_{2}$ release from the marsh but only during dry-down. Elevated salinity increased root mortality at both a freshwater and brackish marsh. Under continuously elevated salinity in mesocosms, net ecosystem productivity (NEP) was unaffected by elevated salinity in a freshwater marsh exposed to brackish conditions $(0 \rightarrow 8 \mathrm{ppt})$, but NEP significantly increased with P enrichment. Elevated salinity led to a higher turnover of live to dead roots, resulting in a $\sim 2$-cm loss in soil elevation within 1 year of exposure to elevated salinity. When exposing a brackish marsh to more saline conditions $(10 \rightarrow 20$ 
ppt), NEP, aboveground biomass production, and root growth all significantly decreased with elevated salinity, shifting the marsh from a net $\mathrm{C}$ sink to a net $\mathrm{C}$ source to the atmosphere. Elevated salinity $(10 \rightarrow 20$ ppt) did not increase soil elevation loss, which was already occurring under brackish conditions, but when coupled with a drought event, elevation loss doubled. My findings suggest these hypotheses for the drivers and mechanisms of peat collapse. When freshwater marshes are first exposed to elevated salinity, soil structure and integrity are negatively affected through loss of live roots within the soil profile, leaving the peat vulnerable to collapse even though aboveground productivity and NEP may be unaffected. Subsequent dry-down events where water falls below the soil surface further accelerate peat collapse. Although saltwater intrusion into freshwater wetlands may initially stimulate primary productivity through a P subsidy, the impact of elevated salinity on root and soil structure has a greater deleterious effect and may ultimately be the factors that lead to the collapse of these marshes. 
TABLE OF CONTENTS

CHAPTER PAGE

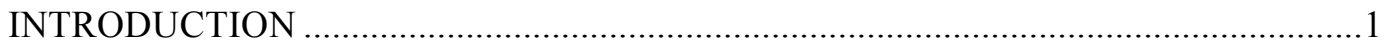

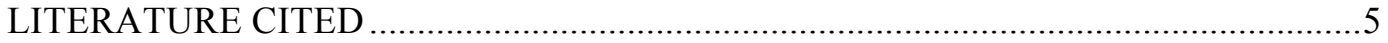

I. SALINITY PULSES IN BRACKISH AND FRESHWATER

MARSHES INTERACT WITH SEASONAL DRY-DOWN TO

INCREASE ECOSYSTEM CARBON LOSS IN THE FLORIDA

COASTAL EVERGLADES..........................................................................

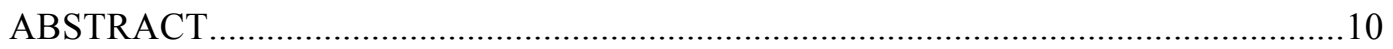

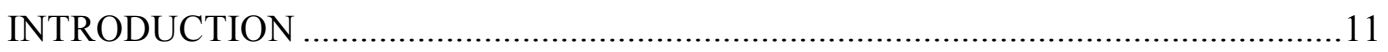

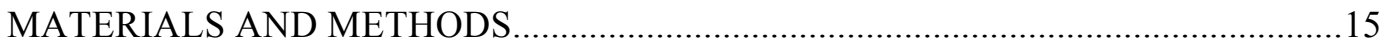

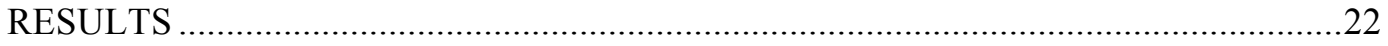

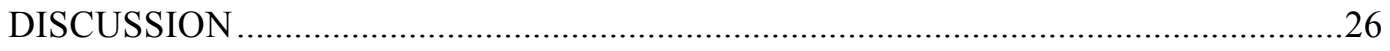

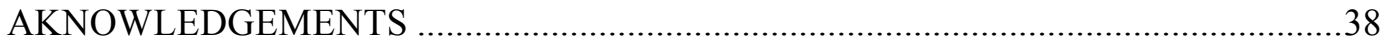

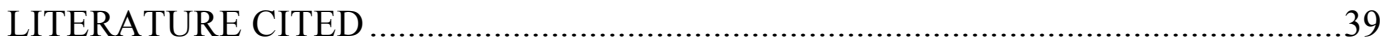

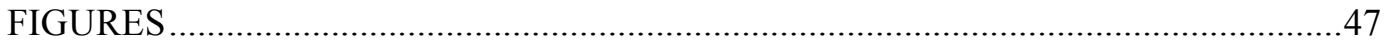

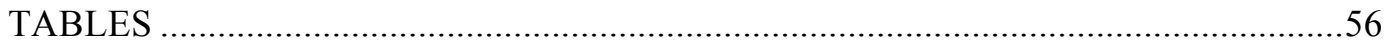

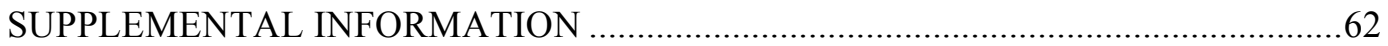

II. BALANCING NUTRIENT SUBSIDY AND SALINITY STRESS:

SHORT- AND LONG-TERM EFFECTS OF SALTWATER

INTRUSION ON FRESHWATER WETLAND ECOSYSTEM

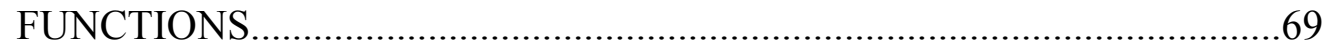

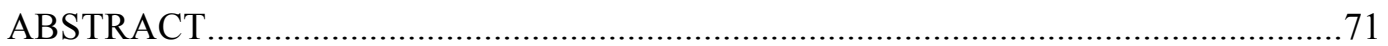

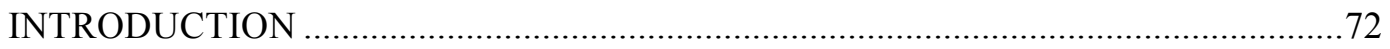

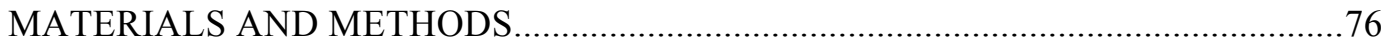

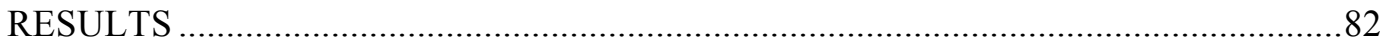

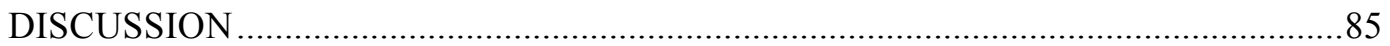

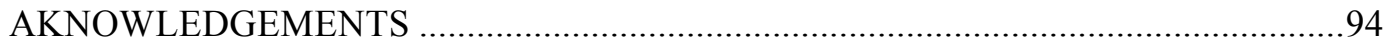

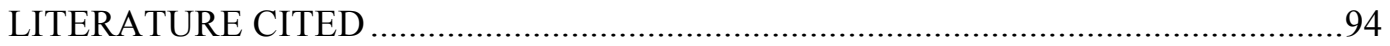

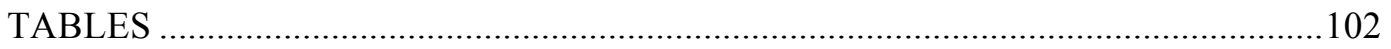

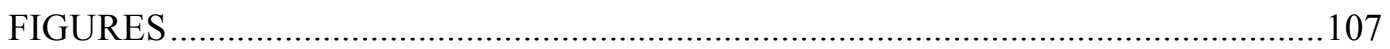

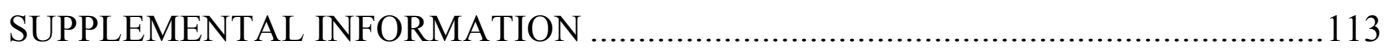

III. DECLINES IN PLANT PRODUCTIVITY DRIVE CARBON LOSS

FROM COASTAL WETLAND ECOSYSTEMS EXPOSED TO

SALTWATER INTRUSION AND SEA-LEVEL RISE................................117

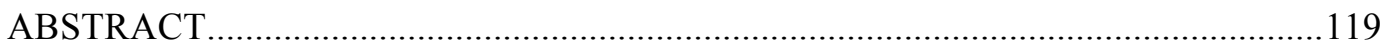

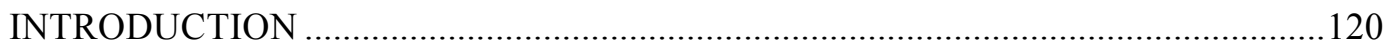

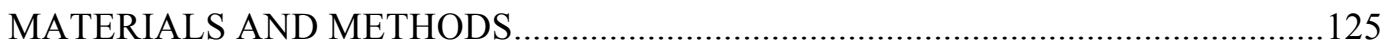

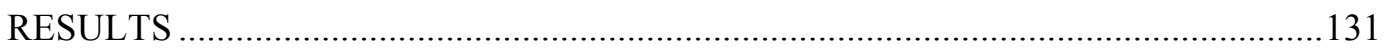

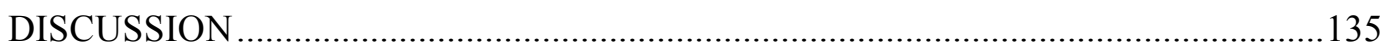

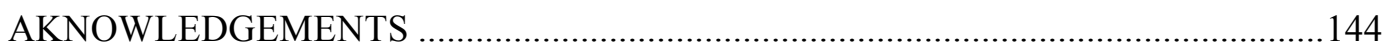

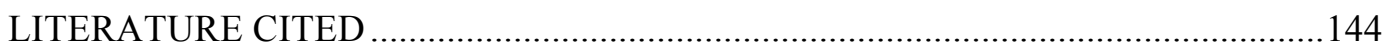


TABLES …

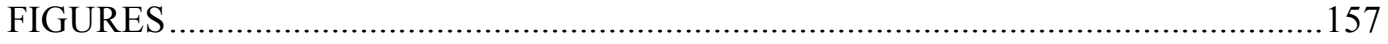

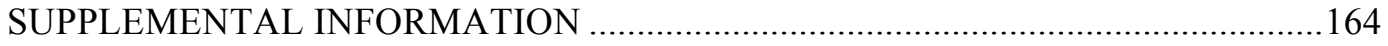

IV. SALTWATER INTRUSION AND DROUGHT DRIVE PEAT COLLAPSE IN A COASTAL PEATLAND.................................................168

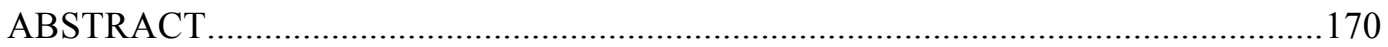

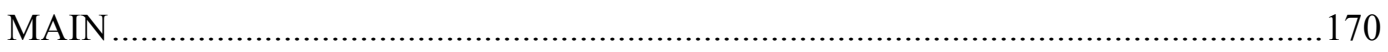

IMPLICATIONS FOR PEAT COLLAPSE …………………..................................177

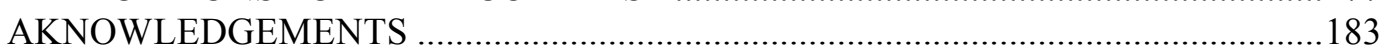

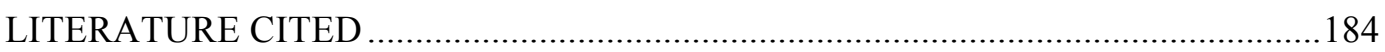

SUPPLEMENTAL INFORMATION ……………………………………………....189

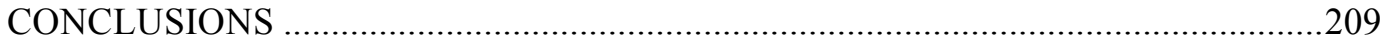

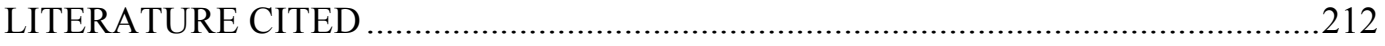

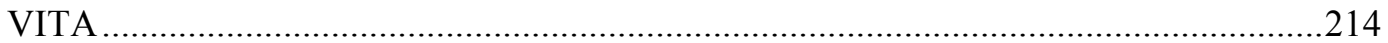




\section{LIST OF TABLES}

TABLE

PAGE

\section{CHAPTER I}

1 Soil physicochemical properties (mean $\pm \mathrm{SE}, \mathrm{n}=6$ ) by site and by depth.

2 Full statistical results from a linear mixed model for porewater constituents from the freshwater (FW) and brackish water (BW) sites given treatment (trt) and date. Interpreted results in bold. Data presented as $\mathrm{F}$ (numerator degrees of freedom,denominator degrees of freedom) $=\mathrm{F}$ value, $\mathrm{P}=\mathrm{P}$ value. The arrows indicate, if significant, in what direction elevated salinity altered the given parameter. DOC dissolved organic carbon, $\mathrm{NH}_{4}{ }^{+}$ammonium, TDN total dissolved nitrogen, $\mathrm{SO}_{4}{ }^{2-}$ sulfate, TDP total dissolved phosphorus, SRP soluble reactive phosphorus

3 Mean $\pm \mathrm{SE}$ of C, N, and P sawgrass leaf content for each year. Subscripted letters represent differences between year and treatment within a site from a one-way ANOVA

Full statistical results from a linear mixed model for all biomass and flux measurements. Interpreted results in bold. Data presented as $\mathrm{F}$ (numerator degrees of freedom, denominator degrees of freedom) $=\mathrm{F}$ value, $\mathrm{P}=\mathrm{P}$ value. ANPP aboveground net primary productivity, GEP gross ecosystem productivity, $\mathrm{ER}_{\mathrm{CO} 2}$ ecosystem respiration of carbon dioxide, NEP net ecosystem productivity, $\mathrm{CH} 4$ methane.

5 Belowground live root biomass (mean $\pm \mathrm{SE} \mathrm{g} \mathrm{C} \mathrm{m}^{-2}$ ) after two years of control (+AMB) and elevated salinity $(+$ SALT) from each site, each treatment and from specific depths. A two-way ANOVA was run separately for each site with Treatment and Depth as factors. Total depth was compared for each site separately using an independent t-test. Letters indicates a significant difference $(\mathrm{P}<0.10)$.....

6 Mean \pm SE of net ecosystem productivity (NEP), gross ecosystem productivity (GEP), ecosystem respiration of CO2 (ER $\left.\mathrm{CO}_{\mathrm{C}}\right)$, and ecosystem respiration of $\mathrm{CH} 4\left(\mathrm{ER}_{\mathrm{CH} 4}\right)$ from the brackish water $(\mathrm{BW})$ and freshwater (FW) sites, separated by the "no-chamber" control, addition of ambient water ( + AMB), and the addition of saltwater $(+$ SALT) plots. Fluxes were separated into wet (water covering the soil surface) and dry (no surface water) periods. A negative NEP indicates a flux from the marsh to the atmosphere. Subscripts represent the results of a two-way repeated measures ANOVA. Values without superscripts 
indicates that there was no significant difference between treatments for that parameter.

\section{CHAPTER II}

1 Porewater temperature, salinity, $\mathrm{pH}$, and dissolved constituents. Data represent mean $(\mathrm{n}=6$ replicates $) \pm 1$ standard error of temperature, salinity, $\mathrm{pH}$, and dissolved porewater constituents averaged across treatments. DOC, $\mathrm{NO}_{2}{ }^{-}, \mathrm{NO}_{3}{ }^{-}, \mathrm{NH}_{4}{ }^{+}$, and SRP are in $\mu \mathrm{mol} \mathrm{L}{ }^{-1}, \mathrm{HS}^{-}$is in $\mathrm{mM}$. Letters represent significant differences among treatments from a multiple comparison test (LSMEANS, Tukey adjusted). DOC dissolved organic carbon, $\mathrm{NO}_{2}{ }^{-}$nitrate, $\mathrm{NO}_{3}{ }^{-}$nitrite, $\mathrm{NH}_{4}{ }^{+}$ammonium, SRP soluble reactive phosphorus.

2 Full statistical results for the linear mixed model. Model run with time as an independent variable for temperature, salinity, $\mathrm{pH}$, dissolved porewater constituents, ecosystem $\mathrm{C}$ flux, biomass, and redox. Interpreted results are in bold. Data presented as $\mathrm{F}$ (numerator degrees of freedom,denominator degrees of freedom) $=\mathrm{F}$ value, $\mathrm{P}=\mathrm{P}$ value. $\mathrm{DOC}$, TOC, $\mathrm{NO}_{2}^{-}, \mathrm{NO}_{3}^{-}, \mathrm{NH}_{4}{ }^{+}$, and SRP are in $\mu \mathrm{mol} \mathrm{L}{ }^{-1}$. Interpreted results are in bold. DOC dissolved organic carbon, $\mathrm{NH}_{4}{ }^{+}$ammonium, TDN total dissolved nitrogen, $\mathrm{SO}_{4}{ }^{2-}$ sulfate, TDP total dissolved phosphorus, SRP soluble reactive phosphorus, GEP gross ecosystem productivity, $\mathrm{ER}_{\mathrm{CO} 2}$ ecosystem respiration of $\mathrm{CO}_{2}$, NEP net ecosystem productivity, ANPP aboveground net primary productivity

3 Averaged carbon flux measured over the experimental period. Data represent the mean $(n=4$ or 6$) \pm 1$ SE of net ecosystem productivity (NEP), gross ecosystem productivity (GEP), ecosystem respiration of $\mathrm{CO}_{2}\left(\mathrm{ER}_{\mathrm{CO} 2}\right)$, soil $\mathrm{CO}_{2}$ (all in $\mu \mathrm{mol} \mathrm{CO}_{2} \mathrm{~m}^{-2} \mathrm{~s}^{-1}$ ), and soil $\mathrm{CH}_{4}$ flux (nmol $\mathrm{CH}_{4} \mathrm{~m}^{-2} \mathrm{~s}^{-1}$ ) from each treatment over the duration of the experiment. Letters represent significant differences among treatments from a multiple comparison test (LSMEANS, Tukey adjusted)

4 Calculated sustained-flux global warming potential (SGWP) over a 100year period and corrected net ecosystem productivity (NEP) accounting for the contribution of methane $\left(\mathrm{CH}_{4}\right)$ to the global greenhouse carbon balance. All units are in $\mathrm{mg} \mathrm{C} \mathrm{m} \mathrm{min}^{-1}$. SGWP is calculated as 45 times the measured soil $\mathrm{CH}_{4}$ flux when $\mathrm{CH}_{4}$ was emitted, and as 203 times soil $\mathrm{CH}_{4}$ flux when there was uptake (Salt) (Neubauer and Megonigal 2015). Corrected NEP is calculated as the difference between NEP and SGWP....106

\section{CHAPTER III}

1 Porewater salinity, $\mathrm{pH}$, redox, and dissolved constituents for the soilonly experiment. Data represents mean \pm 1 SE ( $n=6$ replicates); see linear mixed model results (Table S2) for significant differences 
between the two experiments. DOC, $\mathrm{NH}_{4}{ }^{+}, \mathrm{TDN}$, and $\mathrm{SO}_{4}{ }^{2-}$ are in $\mathrm{mg} \mathrm{L}^{-}$ ${ }^{1}, \mathrm{HS}^{-}$is in $\mathrm{mM}$, TDP and SRP are $\mu \mathrm{M}$, and redox potential is in $\mathrm{mV}$. $\mathrm{Amb}=$ Ambient salinity, Salt $=$ Elevated Salinity, Sub $=$ Submerged, $\operatorname{Exp}=$ Exposed

2 Full statistical results for the linear mixed model run with time as an independent variable for $\mathrm{C}$ flux and aboveground net primary productivity (ANPP). Results with $\alpha<0.05$ are in bold. Data presented as $\mathrm{F}$ (numerator degrees of freedom,denominator degrees of freedom) $=$ $\mathrm{F}$ value, $\mathrm{P}=\mathrm{P}$ value. GEP gross ecosystem productivity, $\mathrm{ER}_{\mathrm{CO} 2}$ ecosystem respiration of $\mathrm{CO}_{2}$, NEP net ecosystem productivity.

Flux rates from the plant-soil experiment. Values represent the mean $\left(\mu \mathrm{mol} \mathrm{CO}_{2}\right.$ or $\left.\mathrm{CH}_{4} \mathrm{~m}^{-2} \mathrm{~s}^{-1}\right) \pm 1 \mathrm{SE}$ for soil $\mathrm{CO}_{2}(\mathrm{n}=90)$, soil $\mathrm{CH}_{4}(\mathrm{n}=36)$, gross ecosystem productivity (GEP), ecosystem respiration of $\mathrm{CO}_{2}$ $\left(\mathrm{ER}_{\mathrm{CO} 2}\right)$, and net ecosystem productivity $(\mathrm{NEP} ; \mathrm{n}=52)$ compared over the entire experiment for each treatment for the plant-soil experiment. See mixed model results (Table 2) for significant differences. Amb $=$ Ambient salinity, Salt $=$ Elevated Salinity, $\mathrm{Sub}=$ Submerged, Exp $=$ Exposed.

Coefficient of determination for linear relationships between Cladium jamaicense aboveground biomass and ecosystem $\mathrm{CO}_{2}$ exchange [gross ecosystem productivity (GEP), net ecosystem productivity (NEP), and ecosystem respiration $\left.\left(E_{\mathrm{CO} 2}\right)\right] . \mathrm{ns}=$ non-significant $(\mathrm{p}>0.05),{ }^{*} \mathrm{p} \leq 0.05$, $* * p<0.01$. Amb $=$ Ambient salinity, Salt $=$ Elevated Salinity, Sub $=$ Submerged, Exp $=$ Exposed.

Soil $\mathrm{CO}_{2}$ and $\mathrm{CH}_{4}$ efflux compared across similar periods and treatments for each experiment. Values represent the mean $\left(\mu \mathrm{mol} \mathrm{CO}_{2}\right.$ or $\mathrm{CH}_{4} \mathrm{~m}^{-2} \mathrm{~s}^{-}$ $\left.{ }^{1}\right) \pm 1$ SE. See mixed model results for significant differences between treatments (Table 2) and experiments (Table S3). Amb = Ambient salinity, Salt $=$ Elevated Salinity, $\mathrm{Sub}=$ Submerged, Exp $=$ Exposed 


\section{CHAPTER IV}

1 Net ecosystem carbon balance of a brackish water marsh. Mean $\pm 1 \mathrm{SE}$ of the net annual ecosystem carbon (C) balance $\left(\mathrm{g} \mathrm{C} \mathrm{m}^{-2} \mathrm{yr}^{-1}\right)$ for a brackish water marsh. A positive number indicates an input of $\mathrm{C}$ to the marsh, while a negative number indicates a net output of $\mathrm{C}$ from the marsh. Statistical information regarding the influence of elevated salinity, drought, and their combined effects can be found in Table S2. $\mathrm{Amb}=$ Ambient salinity, Salt $=$ Elevated Salinity, Sub $=$ Submerged, $\mathrm{Exp}=$ Exposed. $\mathrm{n}=4$ for NEP, GEP, ERCO2; $\mathrm{n}=6$ for Soil CO2, ANPP, Root ingrowth, Root Decomp, and Leaf Decomp. NEP net ecosystem productivity, GEP gross ecosystem productivity, ERCO2 ecosystem respiration of $\mathrm{CO} 2$, ANPP aboveground net primary productivity, Decomp decomposition.

\section{LIST OF FIGURES}

\section{FIGURES}

\section{CHAPTER I}

1 Experimental setup at the FW site (not to scale). The setup was similar at the BW site. Sixteen plots were established along a boardwalk, with a 3$m$ buffer zone between the saltwater-amended plots and the ambient water-amended plots. "No-chamber" controls received no water additions. The +SALT plots were positioned downstream of flow to minimize contamination of the control plots

2 Mean $(\mathrm{n}=6) \pm 1 \mathrm{SE}$ of monthly porewater temperature, salinity, $\mathrm{pH}$, alkalinity, sulfate $\left(\mathrm{SO}_{4}{ }^{2-}\right)$, dissolved organic carbon (DOC), ammonium $\left(\mathrm{NH}_{4}{ }^{+}\right)$, total dissolved nitrogen (TDN), soluble reactive phosphorus (SRP), and total dissolved phosphorus (TDP) from the freshwater (FW) and brackish water (BW) sites over the two-year duration of the study taken at $15-\mathrm{cm}$ depth from the ambient water $(+\mathrm{AMB})$ and saltwater $(+\mathrm{SALT})$ addition plots. Salinity is reported as parts per thousand, Alkalinity, $\mathrm{SO}_{4}{ }^{2-}$, DOC, $\mathrm{NH}_{4}{ }^{+}$, and TDN are reported in $\mathrm{mg} \mathrm{L}^{-1}$, and SRP and TDP are reported in $\mu \mathrm{g} \mathrm{L^{-1 }}$

3 Mean $(\mathrm{n}=6) \pm 1$ SE of monthly porewater (PW) and surface water (SW) salinity and daily water depth from the brackish water site within the +ambient-water plots. Soil surface is plotted as the 0 -cm water mark (dashed line) to show its relation to water depth. Solid lines show the results of a piecewise regression with relevant change-points for PW salinity

4 Mean $(n=6) \pm 1$ SE of monthly porewater sulfide at $15-\mathrm{cm}$ depth at the freshwater (FW) and brackish water (BW) sites from the ambient-water 
amended (+AMB) and saltwater amended (+SALT) plots.

Change in Cladium jamaicense (sawgrass) culm density and aboveground live biomass over time at the freshwater (FW) and brackish water (BW) sites for the ambient amended (+AMB) and saltwater amended $(+$ SALT $)$ treatments. Points represent the monthly mean $(n=6)$ \pm 1 SE. Stars above the data point indicate that there was a significant (LSMEANS, $\mathrm{P}<0.10$ ) difference among treatments for that site

Annual mean $(n=6) \pm 1$ SE of sawgrass aboveground net primary productivity (ANPP) separated by freshwater (FW) and brackish water (BW) site, ambient-water amended (+AMB) and saltwater-amended $(+\mathrm{SALT})$ treatments, and year.

Instantaneous rates (mean, $\mathrm{n}=4 \pm 1 \mathrm{SE}$ ) of freshwater gross ecosystem productivity (a; GEP), ecosystem respiration of CO2 (b; ER), and net ecosystem productivity (c; NEP) and brackish water GEP (d), ER $\mathrm{EO}_{\mathrm{CO}}(\mathrm{e})$, and NEP (f) over 2 years from both the freshwater and brackish sites. The bottom panel also plots water level (blue line) in relation to the soil surface over time. For figure clarity, the "no-chamber" control plots were not added, as they were not significantly different from the + AMB plots $(\mathrm{P}>0.10)$. Stars represent months in which treatments were significantly different from each other (LSMEANS, $\mathrm{P}<0.10$ ).

Estimated ecosystem $\mathrm{C}$ cycling over the two-year study period for net ecosystem productivity (NEP), gross ecosystem productivity (GEP), and ecosystem respiration of $\mathrm{CO}_{2}\left(\mathrm{ER}_{\mathrm{CO} 2}\right)$ from the freshwater $(\mathrm{FW})$ and brackish water (BW) sites and how it changes ambient water (+AMB) or saltwater (+SALT) pulses. A negative NEP indicates that the marsh is a net $C$ source to the atmosphere. Values represent mean $(n=6) \pm 1$ SD flux over the experimental timeframe in $\mathrm{g} \mathrm{C} \mathrm{m}^{-2} \mathrm{y}^{-1}$. Annual flux was calculated using previously published GEP, PAR, ER, and temperature relationships for sawgrass (see Supplemental Methods) and previously derived light response curves for a sawgrass freshwater and brackish marsh (Neubauer 2013, Wilson et al. 2015).

\section{CHAPTER II}

1 Change in sawgrass aboveground live biomass over time for each treatment. Points represent the monthly mean $(n=6$ replicates per treatment) $\pm 1 \mathrm{SE}$

2 Measured aboveground net primary productivity (ANPP) separated by treatment and year. Letters represent the results of a Tukey's post-hoc analysis performed separately for each year. Points represent the annual mean $(\mathrm{n}=6$ replicates per treatment $) \pm 1$ SE. 
3 Live aboveground (AG) and belowground (BG) biomass at the end of the experiment. Aboveground biomass was calculated allometrically, whereas belowground biomass was measured through soil coring down to 30-cm depth. Subscripted letters represent differences among treatments from a Tukey's HSD post-hoc test. Bars represent the mean $(\mathrm{n}=6$ replicates per treatment $) \pm 1 \mathrm{SE}$ in grams dry weight of material per meter squared. The number at the top of each treatment represents the ratio of aboveground to belowground biomass

4 Monthly soil $\mathrm{CO}_{2}$ efflux over time for each treatment. Points represent the monthly mean $(n=6$ replicates per treatment $) \pm 1$ SE.

5 Measured soil methane $\left(\mathrm{CH}_{4}\right)$ efflux over the first year of the experiment. Points represent the monthly mean $(n=4$ replicates per treatment) $\pm 1 \mathrm{SE}$

6 Instantaneous flux of gross ecosystem productivity (a; GEP), ecosystem respiration of $\mathrm{CO}_{2}$ (b; ER), and net ecosystem productivity (c; NEP). Points represent the monthly mean $(n=4$ replicates per treatment $) \pm 1$ SE...112

\section{CHAPTER III}

1 Photographs taken in March 2015 in the brackish water portion of Everglades National Park showing (A) a group of sawgrass culms forming a pedestal and (B) a close up of the culms and exposed roots. The delineation between the bottom of the culms and the exposed roots indicates that the surface of the soil has collapsed about $30 \mathrm{~cm}$ (distance from bottom of the culm to current soil surface) over an unknown period of time.

2 Daily soil $\mathrm{CO}_{2}$ efflux during the 8-day ramp-up period of the soil-only experiment in which salinity was raised by $\sim 1$ ppt every day in the elevated salinity monoliths from an ambient salinity of $10 \mathrm{ppt}$ to an elevated salinity of $20 \mathrm{ppt}$. Salinity in the ambient salinity tanks remained relatively constant during this same period. Points represent the mean $(\mathrm{n}=6$ replicates $) \pm 1 \mathrm{SE}$. Amb $=$ Ambient salinity, Salt $=$ Elevated Salinity, Sub $=$ Submerged, Exp $=$ Exposed

3 Soil $\mathrm{CH}_{4}\left(\mathrm{n}=4\right.$ replicates) and $\mathrm{CO}_{2}$ efflux $(\mathrm{n}=6$ replicates $)$ over time for the soil-only experiment. Points represent means $\pm 1 \mathrm{SE}$. Amb $=$ Ambient salinity, Salt $=$ Elevated Salinity, $\mathrm{Sub}=$ Submerged, Exp $=$ Exposed

4 Soil $\mathrm{CH}_{4}(\mathrm{n}=4$ replicates $)$ and $\mathrm{CO}_{2}$ efflux $(\mathrm{n}=6$ replicates $)$ over time for the plant-soil experiment. Points represent mean $\pm 1 \mathrm{SE}$. Amb $=$ 
Ambient salinity, Salt $=$ Elevated Salinity, $\mathrm{Sub}=$ Submerged, $\operatorname{Exp}=$ Exposed

5 Monthly instantaneous gross ecosystem productivity (GEP) (a), ecosystem respiration of $\mathrm{CO}_{2}\left(\mathrm{ER}_{\mathrm{CO} 2}\right)(\mathrm{b})$, and net ecosystem productivity (NEP) (c) in micromoles of $\mathrm{CO}_{2}$ per meter squared per second over the experimental period for plant-soil experiment. A negative value indicates a flux of $\mathrm{CO}_{2}$ from the marsh to the atmosphere. Points represent means $(\mathrm{n}=6$ replicates $) \pm 1 \mathrm{SE}$. Amb $=$ Ambient salinity, Salt $=$ Elevated Salinity, $\mathrm{Sub}=$ Submerged, Exp $=$ Exposed.

$6 \quad$ Mean $(\mathrm{n}=6) \pm 1$ standard error of Cladium jamaicense (sawgrass) aboveground net primary productivity (ANPP) across the four treatments. Amb $=$ Ambient salinity, Salt $=$ Elevated Salinity, Sub = Submerged, Exp $=$ Exposed.

$7 \quad$ Schematic of estimated ecosystem $\mathrm{C}$ cycling for net ecosystem productivity (NEP), gross ecosystem productivity (GEP), ecosystem respiration of $\mathrm{CO}_{2}\left(\mathrm{ER}_{\mathrm{CO} 2}\right)$, and soil $\mathrm{CO}_{2}$ efflux from the plant-soil experiment and how it changes with elevated salinity and/or water depth. Arrows pointing down indicate $\mathrm{C}$ entering the marsh, while upward pointing arrows indicate $\mathrm{C}$ leaving the marsh to the atmosphere. Values represent mean $(n=6) \pm 1$ SE flux over the experimental timeframe in $g$ $\mathrm{C} \mathrm{m}^{-2} \mathrm{y}^{-1}$, and the width of the arrows is scaled to the overall flux. Annual flux was calculated using established methods and previously derived light response curves for a $\mathrm{C}$. jamaicense brackish water marsh (Neubauer, 2013; Wilson et al., 2015). Amb = Ambient salinity (10 ppt), Salt $=$ Elevated salinity $(20 \mathrm{ppt})$, Exp $=$ Soil surface exposed $4-\mathrm{cm}, \mathrm{Sub}$ $=$ Soil surface submerged.

\section{CHAPTER IV}

1 Photos showing peat collapse in the coastal Everglades $5 \mathrm{~km}$ inland. a, aerial photography showing open water ponds dotting the landscape. $b$, a group of sawgrass culms at ground level within this marsh. c, zoomed-in portion of photo $b$ showing the delineation between the bottom of the culms and exposed roots. d, a recently collapsed sawgrass pedestal. Photo credits: a, S.E.D.; b-d, B.J.W.

2 Soil elevation change relative to the elevation at the start of the experiment. Also plotted is water depth relative to the soil surface (blue line). Points represent mean $(\mathrm{n}=6) \pm 1 \mathrm{SE} . \mathrm{Amb}=$ Ambient salinity, Salt $=$ Elevated Salinity, $\mathrm{Sub}=$ Submerged, $\operatorname{Exp}=$ Exposed

3 Soil elevation change relative to the elevation at the start of two separate experiments. The data plotted come from this experiment (filled 
symbols) and from a similar mesocosm experiment on freshwater sawgrass peat monoliths (open symbols). All treatments were not subjected to drought and were completely inundated for the entire experimental period. Points represent mean $(n=6) \pm 1$ SE. BW $=$ brackish water, $\mathrm{FW}=$ freshwater, $\mathrm{ppt}=$ parts per thousand salinity.

$4 \quad$ Historical water level from a brackish water site in the Everglades. (a) Weekly mean $(\mathrm{n}=7) \pm 1 \mathrm{SD}$ water level at the brackish water site relative to the soil surface from 2001 to 2017. (b) Daily water level at the brackish water site from 2001 to 2017. The dashed line represents the soil surface, while the blue line represents either the water level during our one year mesocosm experiment (a) or the minimum water level in our drought experiment $(-20 \mathrm{~cm}$; b). Water level data comes from the USGS EDEN gauge NP6.

5 Ambient porewater and surface water salinity at the brackish water marsh. Mean $(n=6) \pm 1$ SE of monthly porewater $(\mathrm{PW})$ and surface water (SW) salinity (ppt) and daily water depth relative to the soil surface from the brackish water site within the +ambient-water plots (Wilson et al. in prep). Soil surface is plotted as the 0-cm water mark (dashed line) to show its relation to water depth. Solid black lines show the results of a piecewise regression with relevant change-points for PW salinity. 


\section{INTRODUCTION}

Wetlands, although occupying only $\sim 5-8 \%$ of the earth's surface, store $20-30 \%$ of soil carbon $(\mathrm{C})$ because of their high productivity and low decomposition rate (Mitsch and Gosselink 2007, Nahlik and Fennessy 2016). Yet wetlands are highly susceptible to ecosystem fluctuations such as changes in hydrology, water chemistry, and vegetation regime (Deegan et al. 2012, Webster et al. 2013, Bernal et al. 2017). Coastal wetlands are particularly vulnerable to saltwater intrusion. Saltwater intrusion brings new ionic constituents (salts), an alternate source of nutrients, and altered hydrologic flow to coastal wetlands (Herbert et al. 2015). With average global sea level rising $\sim 3 \mathrm{~mm} \mathrm{yr}^{-1}$ (Ryan and Law 2005), and recent increases up to $9 \mathrm{~mm} \mathrm{yr}^{-1}$ in some coastal areas (Wdowinski et al. 2016), saltwater intrusion in low-lying freshwater and brackish coastal wetlands will increase, potentially altering ecosystem $\mathrm{C}$ dynamics through effects on plants and soils (Valentine 2002, Whalen 2005).

Coastal peat marshes are susceptible to both saltwater intrusion and changes in water depth (Herbert et al. 2015, Whittle and Gallego-Sala 2016), but little is known about how exposure to saltwater affects organic matter accumulation and peat stability. In areas with low inorganic sediment input, peatland soils are highly organic $(>85 \%)$ and vulnerable to external drivers such as freshwater diversion and effects of climate change (Nyman et al. 1990, Delaune et al. 1994, McVoy et al. 2011). The Everglades is the largest coastal peatland in the United States $\left(>6000 \mathrm{~km}^{2}\right.$; Richardson et al. 2008$)$ and one of the most vulnerable to sea-level rise (SLR), as $60 \%$ of Everglades National Park is at or below $0.9 \mathrm{~m}$ in elevation (Pearlstine et al. 2010). Freshwater flow through the Everglades has been greatly reduced by compartmentalization through creation of water 
storage areas and overall reduction in water delivery, resulting in less freshwater flow into the Everglades. SLR and reduced freshwater flow leaves the ecosystem highly vulnerable to saltwater intrusion (Light and Dineen 1994, Saha et al. 2011).

The term "peat collapse" has been used to describe a relatively rapid shift in soil $\mathrm{C}$ balance, leading to a net loss of organic $\mathrm{C}$ and loss of soil elevation, which culminates in a conversion of vegetated marsh to open water ponds (Delaune et al. 1994, Wanless and Vlaswinkel 2005). Peat collapse has been documented to varying degrees in different coastal wetlands and has been attributed to changes in microbial processes, increased sulfate reduction, sulfide accumulation, eutrophication from excess nitrogen $(\mathrm{N})$ inputs, inadequate plant production, and vegetation damage from tropical storms. All of these factors could contribute to the instability of inland marshes (Delaune et al. 1994, Cahoon et al. 2003, Deegan et al. 2012, Voss et al. 2013). Areas of peat collapse have been observed in the brackish and saline marsh areas of the coastal Everglades, yet the mechanisms behind this collapse are not understood (Wanless and Vlaswinkel 2005, Chambers et al. 2015). Therefore, understanding how factors associated with SLR that exacerbate saltwater intrusion in the coastal Everglades and potentially alter $C$ storage and peat stability is critically important for the future of Everglades coastal wetlands.

In the wetlands of the southern Everglades, the dynamic interplay between salinity, phosphorus (P) load, and inundation period controls ecosystem productivity (Childers et al. 2006, Troxler et al. 2014) and, thus, peat stability (Nyman et al. 2006, Baustian et al. 2012). Elevated salinity in coastal wetlands can produce plant morphological and physiological changes (Larcher 2003, Rejmankova and Macek 2008) that affect photosynthetic efficiencies, growth, maintenance, and nutrient uptake 
(Pezeshki et al. 1987a, Pezeshki et al. 1987b, Neubauer 2013). The salinity stress on vegetation and decrease in productivity can decrease $\mathrm{C}$ inputs to the soil (Pezeshki et al. 1989, Neubauer 2013).

When saltwater intrudes into karstic systems such as the Everglades, P adsorbed to limestone bedrock can be replaced by cations within saltwater, increasing water soluble reactive phosphorus (SRP) concentrations. In oligotrophic wetlands, this newly available SRP can act as a subsidy to the wetland biota. Microbial community structure and processes respond rapidly to nutrient subsidies (Corstanje et al. 2007). In oligotrophic soils, $\mathrm{P}$ enrichment has been shown to stimulate microbial $\mathrm{C}$ processing and soil $\mathrm{CO}_{2}$ production (Amador and Jones 1993, DeBusk and Reddy 1998, Wright and Reddy 2007, Medvedeff et al. 2015). Additionally, P enrichment can stimulate plant biomass growth and thus provide a $\mathrm{C}$ addition to the soil, though this response is usually much slower than the microbial decomposition response and can take years to produce visible change (Chiang et al. 2000, Noe et al. 2002). Nutrient additions can also change biomass allocation within wetland vegetation, generally causing more shoot over root production (Poorter and Nagel 2000). As peatlands rely on the input of root organic material for soil maintenance and stabilization, an influx of nutrients can actually destabilize and collapse the marsh (Deegan et al. 2012).

Finally, inundation period (water level relative to the soil surface) can have strong influence on the flow of $\mathrm{C}$ through the marsh. Under waterlogged conditions, production outpaces decomposition and $\mathrm{C}$ accumulates in soils over millennia. However, a shift in hydrology towards drier conditions, caused by either drought or drainage, can cause large amounts of stored $\mathrm{C}$ to be released to the atmosphere through enhanced aerobic 
decomposition and can shift the ecosystem from a net $\mathrm{C}$ sink to a $\mathrm{C}$ source (Ise et al. 2008, Fenner and Freeman 2011, Wang et al. 2015). As stored C effluxes to the atmosphere, degradation of the soil structure can lead to a loss of soil elevation and a sudden (within a year) collapse of the peat (Cahoon et al. 2003). Given accelerating SLR and greater saltwater intrusion into coastal wetlands, understanding how ecosystem productivity is affected by changes in the drivers associated with saltwater intrusion is crucial. Here, I test how elevated salinity, greater P loading, and changes in inundation regimes alter ecosystem productivity to influence peat collapse.

In Chapter I, I conducted an in situ field experiment to investigate how soil biogeochemistry and ecosystem $\mathrm{C}$ cycling in a freshwater and brackish marsh are altered by monthly pulses of elevated salinity. Chapters II-IV expand on my field observations by investigating the effects of salinity, $\mathrm{P}$, and inundation on freshwater and brackish marshes through controlled mesocosm experiments. I looked at how a "press" disturbance, in the form of elevated salinity, inundation, and nutrient loading, would impact ecosystem C and soil biogeochemical cycling. In chapter II, I conducted a mesocosm experiment to investigate how elevated salinity and increased P loading affects ecosystem function in a freshwater marsh. In chapter III, I conducted a mesocosm experiment to investigate how elevated salinity and increased inundation affect ecosystem function in a brackish water marsh. Finally, in chapter IV, I expanded on an observation made in chapter I, researching how drought combines with elevated salinity to influence ecosystem function. Chapter I is formatted to be submitted to Ecological Applications, Chapter II is formatted to be submitted to Global Change Biology, Chapter 
III is formatted to be submitted to Ecology, and Chapter IV is formatted to be submitted to Nature Climate Change.

\section{LITERATURE CITED}

Baustian, J. J., I. A. Mendelssohn, and M. W. Hester. 2012. Vegetation's importance in regulating surface elevation in a coastal salt marsh facing elevated rates of sea level rise. Global Change Biology 18:3377-3382.

Bernal, B., J. P. Megonigal, and T. J. Mozdzer. 2017. An invasive wetland grass primes deep soil carbon pools. Global Change Biology 23:2104-2116.

Cahoon, D. R., P. Hensel, J. Rybczyk, K. L. McKee, C. E. Proffitt, and B. C. Perez. 2003. Mass tree mortality leads to mangrove peat collapse at Bay Islands, Honduras after Hurricane Mitch. Journal of Ecology 91:1093-1105.

Chambers, L. G., S. E. Davis, and T. G. Troxler. 2015. Sea Level Rise in the Everglades: Plant-Soil-Microbial Feedbacks in Response to Changing Physical Conditions. Pages 89-112 in J. A. Entry, editor. Microbiology of the Everglades Ecosystem. CRC Press, Boca Raton.

Childers, D. L., D. Iwaniec, D. Rondeau, G. Rubio, E. Verdon, and C. J. Madden. 2006. Responses of sawgrass and spikerush to variation in hydrologic drivers and salinity in Southern Everglades marshes. Hydrobiologia 569:273-292.

Deegan, L. A., D. S. Johnson, R. S. Warren, B. J. Peterson, J. W. Fleeger, S. Fagherazzi, and W. M. Wollheim. 2012. Coastal eutrophication as a driver of salt marsh loss. Nature 490:388.

Delaune, R. D., J. A. Nyman, and W. H. Patrick. 1994. Peat collapse, ponding and wetland loss in a rapidly submerging coastal marsh. Journal of Coastal Research 10:1021-1030.

Herbert, E. R., P. Boon, A. J. Burgin, S. C. Neubauer, R. B. Franklin, M. Ardon, K. N. Hopfensperger, L. P. M. Lamers, and P. Gell. 2015. A global perspective on wetland salinization: ecological consequences of a growing threat to freshwater wetlands. Ecosphere 6.

Larcher, W. 2003. Physiological plant ecology. 4th edition. Springer, Berlin.

Light, S. S., and J. W. Dineen. 1994. Water control in the Everglades: A historical perspective. Pages 47-84 in S. M. Davis and J. C. Ogden, editors. Everglades: The Ecosystem and its Restoration. St. Lucie Press, Delray Beach. 
McVoy, C. W., W. P. Said, J. Obeysekera, J. Van Arman, and T. W. Dreschel. 2011. Landscapes and Hydrology of the Predrainage Everglades. University of Florida Press, Gainesville, FL.

Mitsch, W. J., and J. G. Gosselink. 2007. Wetlands. 4th ed. edition. John Wiley \& Sons, Inc., Hoboken, NJ.

Nahlik, A. M., and M. S. Fennessy. 2016. Carbon storage in US wetlands. Nature Communications 7.

Neubauer, S. C. 2013. Ecosystem responses of a tidal freshwater marsh experiencing saltwater intrusion and altered hydrology. Estuaries and Coasts 36:491-507.

Nyman, J. A., R. D. Delaune, and W. H. Patrick. 1990. Wetland soil formation in the rapidly subsiding Mississippi River Deltaic Plain - mineral and organic-matter relationships. Estuarine Coastal and Shelf Science 31:57-69.

Nyman, J. A., R. J. Walters, R. D. Delaune, and W. H. Patrick, Jr. 2006. Marsh vertical accretion via vegetative growth. Estuarine Coastal and Shelf Science 69:370-380.

Pearlstine, L. G., E. V. Pearlstine, and N. G. Aumen. 2010. A review of the ecological consequences and management implications of climate change for the Everglades. Journal of the North American Benthological Society 29:1510-1526.

Pezeshki, S. R., R. D. DeLaune, and W. H. Patrick Jr. 1987a. Response of the freshwater marsh species, Panicum hemitomon Schult., to increased salinity. Freshwater Biology 1:195-200.

Pezeshki, S. R., R. D. Delaune, and W. H. Patrick. 1987b. Effects of flooding and salinity on photosynthesis of Sagittaria lancifolia. Marine Ecology Progress Series 41:8791.

Rejmankova, E., and P. Macek. 2008. Response of root and sediment phosphatase activity to increased nutrients and salinity. Biogeochemistry 90:159-169.

Richardson, C. J., A. Dickson, and M. Ho. 2008. The Effects of Disturbance, Phosphorus, and Water Level on Plant Succession in the Everglades. Pages 531-544 Everglades Experiments. Springer, New York.

Ryan, M. G., and B. E. Law. 2005. Interpreting, measuring, and modeling soil respiration. Biogeochemistry 73:3-27.

Saha, A. K., S. Saha, J. Sadle, J. Jiang, M. S. Ross, R. M. Price, L. Sternberg, and K. S. Wendelberger. 2011. Sea level rise and South Florida coastal forests. Climatic Change 107:81-108. 
Troxler, T. G., D. L. Childers, and C. J. Madden. 2014. Drivers of Decadal-Scale Change in Southern Everglades Wetland Macrophyte Communities of the Coastal Ecotone. Wetlands 34:S81-S90.

Valentine, D. L. 2002. Biogeochemistry and microbial ecology of methane oxidation in anoxic environments: a review. Antonie Van Leeuwenhoek International Journal of General and Molecular Microbiology 81:271-282.

Voss, C. M., R. R. Christian, and J. T. Morris. 2013. Marsh macrophyte responses to inundation anticipate impacts of sea-level rise and indicate ongoing drowning of North Carolina marshes. Marine Biology 160:181-194.

Wanless, H. R., and B. M. Vlaswinkel. 2005. Coastal landscape and channel evolution affecting critical habitats at Cape Sable, Everglades National Park, Florida.

Wdowinski, S., R. Bray, B. P. Kirtman, and Z. H. Wu. 2016. Increasing flooding hazard in coastal communities due to rising sea level: Case study of Miami Beach, Florida. Ocean \& Coastal Management 126:1-8.

Webster, K. L., J. W. McLaughlin, Y. Kim, M. S. Packalen, and C. S. Li. 2013. Modelling carbon dynamics and response to environmental change along a boreal fen nutrient gradient. Ecological Modelling 248:148-164.

Whalen, S. C. 2005. Biogeochemistry of methane exchange between natural wetlands and the atmosphere. Environmental Engineering Science 22:73-94.

Whittle, A., and A. V. Gallego-Sala. 2016. Vulnerability of the peatland carbon sink to sea-level rise. Scientific Reports 6. 


\section{CHAPTER I}

SALINITY PULSES IN BRACKISH AND FRESHWATER MARSHES INTERACT WITH SEASONAL DRY-DOWN TO INCREASE ECOSYSTEM CARBON LOSS IN THE FLORIDA COASTAL EVERGLADES 
Salinity pulses in brackish and freshwater marshes interact with seasonal dry-down to increase ecosystem carbon loss in the Florida Coastal Everglades

Authors: Benjamin J. Wilson ${ }^{1}$, Shelby Servais ${ }^{1}$, Viviana Mazzei ${ }^{1}$, Laura Bauman ${ }^{1}$, Stephen E. Davis ${ }^{2}$, Evelyn Gaiser ${ }^{1}$, Stephen Kelly ${ }^{3}$, John S. Kominoski ${ }^{1}$, Christopher Madden $^{3}$, Jennifer Richards ${ }^{1}$, David Rudnick ${ }^{4}$, Fred Sklar ${ }^{3}$, Joseph Stachelek ${ }^{3,5}$, and Tiffany G. Troxler ${ }^{1}$

${ }^{1}$ Florida International University, Dept. of Biological Sciences and Southeast

Environmental Research Center, Miami, FL 33199

${ }^{2}$ Everglades Foundation, Palmetto Bay, FL 33157

${ }^{3}$ South Florida Water Management District, West Palm Beach, FL 33406

${ }^{4}$ Everglades National Park, Homestead, FL 33034

${ }^{5}$ Michigan State University, East Lansing, MI 48824 


\begin{abstract}
Coastal wetlands are globally important sinks of organic carbon (C). However, it is unknown to what extent wetland $\mathrm{C}$ cycling will be affected by accelerated sea-level rise (SLR) and saltwater intrusion, especially in coastal peat marshes where water flow is highly managed. Our objective was to determine how ecosystem $\mathrm{C}$ balance in coastal peat marshes changes with a doubling of salinity. For two years, we made monthly in situ manipulations of elevated salinity in freshwater (FW) and brackish water (BW) sites within Everglades National Park, FL, USA. Salinity pulses interacted with marsh-specific variability in seasonal hydroperiods whereby effects of elevated pulsed salinity on gross ecosystem productivity (GEP), ecosystem respiration (ER), and net ecosystem productivity (NEP) were dependent on marsh inundation level. We found little effect of elevated salinity on $\mathrm{C}$ cycling when both marsh sites were inundated, but, when water levels receded below the soil surface, the BW marsh shifted from a $\mathrm{C}$ sink to a $\mathrm{C}$ source. During these exposed periods, we observed an approximately 3 -fold increase in $\mathrm{CO}_{2}$ efflux from the marsh as a result of elevated salinity. Initially, elevated salinity pulses did not affect Cladium jamaicense biomass, but aboveground biomass began to be significantly lower in the saltwater amended plots after two years of exposure at the BW site. We found a $65 \%(\mathrm{FW})$ and $72 \%(\mathrm{BW})$ reduction in live root biomass in the soil after two years of exposure to elevated salinity pulses. Regardless of salinity treatment, the FW site was $\mathrm{C}$ neutral while the BW site was a strong $\mathrm{C}$ source $\left(-334\right.$ to $-454 \mathrm{~g} \mathrm{C} \mathrm{m}^{-2}$ $\mathrm{y}^{-1}$ ), particularly during dry-down events. A loss of live roots coupled with annual net $\mathrm{CO}_{2}$ losses as marshes transition from $\mathrm{FW}$ to $\mathrm{BW}$ likely contribute to the collapse of peat soils observed in the coastal Everglades. As SLR increases the rate of saltwater intrusion
\end{abstract}


into coastal wetlands globally, understanding how water management influences $\mathrm{C}$ gains and losses from these systems is crucial. Under current Everglades' water management, drought lengthens marsh dry-down periods, which, coupled with saltwater intrusion, accelerates $\mathrm{CO}_{2}$ loss from the marsh.

\section{INTRODUCTION}

Coastal wetlands are some of the most productive ecosystems in the world and are known for their capacity to store disproportionately large amounts of carbon (C) in their soils despite their relatively small global coverage (Chmura et al. 2003, Duarte et al. 2005, McLeod et al. 2011). Yet, storage of wetland C is highly vulnerable to changing environmental conditions, such as salinity and hydrology. With sea levels rising at $\sim 3$ $\mathrm{mm} \mathrm{y}^{-1}$ (Zhang et al. 2011), coastal freshwater and intertidal wetlands are being exposed to increased duration and spatial extent of inundation and potentially higher salinity water (Herbert et al. 2015).

The Florida Everglades, USA, is one of the largest wetland ecosystems in the world, an International Biosphere Reserve, a UNESCO World Heritage Site, and a Ramsar Wetland of International Importance. The Everglades contains vast amounts of C in its peat soils (Davis et al. 1994, Jerath et al. 2016); however, the Everglades contains only $\sim 24 \%$ of its original peat volume because of anthropogenic modification (Hohner and Dreschel 2015), and climate change pressures keeps this wetland in a state of flux that may potentially alter its $C$ storage capacity. In the early part of the $20^{\text {th }}$ century, the construction of canals and levees diverted the flow of water away from the southern, coastal Everglades, reducing water tables by as much as $2.7 \mathrm{~m}$ and resulting in the loss of 
half the ecosystem (McVoy et al. 2011; Sklar et al. in press). The reduction in freshwater flow into the southern Everglades has reduced the freshwater head, resulting in faster than expected saltwater intrusion into the Biscayne Aquifer which lies underneath the Everglades (Klein and Waller 1985, Saha et al. 2011). In addition to increased saltwater intrusion, less water flowing into the Everglades means more periods of "dry-down," or when water recedes below the soil surface (Sklar et al. 2000). Extended dry-down periods can enhance $\mathrm{C}$ loss from the wetland through greater soil oxidation and microbial metabolism (Wright and Reddy 2001, Reddy and DeLaune 2008). As climate change is expected to change rainfall patterns in southern Florida (Allan and Soden 2008, Li et al. 2012), enhanced magnitude and increased dry-down events are possible (Obeysekera $e t$ al. 2015), which can further exacerbate saltwater intrusion and affect ecosystem C dynamics (see below). Steps have been taken to increase freshwater delivery to the coastal Everglades. Under the Comprehensive Everglades Restoration Plan (CERP) authorized in 2000 , a series of $60+$ projects were proposed to restore the flow of water back to the southern Everglades (Sklar et al. 2005). However, as of 2017, the most critical central decompartmentalization projects still await Federal funding and flows to the southern Everglades have not attained CERP target levels (National Academies of Sciences 2016). The continued intrusion of saltwater into the coastal Everglades has, in some areas, caused drastic changes to the landscape, such as "peat collapse" and the conversion of coastal marshes to open water ponds (Wanless and Vlaswinkel 2005).

In the low-lying and gently sloping coastal Everglades, the effects of saltwater intrusion may be amplified by a combination of a lower freshwater head, because of current water management strategies, and storm surges caused by tropical storms. Storm 
surges bring pulses of saltwater into nearshore brackish-to-freshwater marshes that can impact ecosystem structure, function, and, ultimately, persistence (Herbert et al. 2015). Each pulse brings with it greater amounts of ionic constituents, such as $\mathrm{Cl}^{-}$and $\mathrm{SO}_{4}{ }^{2-}$, normally not seen in high concentrations in these brackish to freshwater marshes. The initial conditions of the marsh likely determine how much these constituents will affect ecosystem functioning. For example, in historically freshwater marshes, pulses of elevated salinity water can cause ions, such as ammonium $\left(\mathrm{NH}_{4}{ }^{+}\right)$, that are adsorbed onto cation exchange sites, to be displaced by ions found in seawater, such as $\mathrm{Na}^{+}, \mathrm{Mg}^{2+}$, and $\mathrm{Ca}^{2+}$ (Seitzinger et al. 1991, Weston et al. 2010). The newly accessible $\mathrm{NH}_{4}^{+}$may be available for vascular plant uptake, especially in $\mathrm{N}$-limited wetlands, but $\mathrm{N}$ uptake rates may slow as salt stress and sulfide (HS ${ }^{-}$) toxicity suppress plant growth (Cormier et al. 2013). Increased $\mathrm{SO}_{4}{ }^{2-}$ availability can increase microbial metabolism and the production of $\operatorname{HS}^{-}$(Lamers et al. 1998, Weston et al. 2011), but also lead to a decrease in plant productivity as a consequence of sulfide toxicity (Spalding and Hester 2007, Lamers et al. 2013). While the effect on ecosystem $\mathrm{C}$ cycling of saltwater pulses into tidal marshes has been increasingly studied (e.g., Chambers et al. 2013, Neubauer 2013, Weston et al. 2014), the ecosystem $C$ responses of non-tidal, nearshore freshwater and brackish marshes to saltwater pulses is still not well known.

Saltwater intrusion can lead to changes in soil biogeochemical cycling that affect ecosystem C dynamics (Weston et al. 2011, Herbert et al. 2015). Many studies have documented changes in $\mathrm{C}$ cycling along coastal marsh salinity gradients, often with contrasting results. Wilson et al. (2015) found that marshes along a salinity gradient in Mobile Bay, AL were losing $\mathrm{CO}_{2}$ to the atmosphere, though it could not be determined if 
this $\mathrm{CO}_{2}$ loss resulted from seasonal saltwater intrusion or if this was an annual trend across sites. Weston et al. (2014) found that both tidal freshwater and mesohaline marshes in the Delaware River Estuary were relatively strong C sinks, while seasonal saltwater intrusion made the oligohaline marsh a net $\mathrm{C}$ source. Ardón et al. (2013) found that seasonal saltwater intrusion coupled with drought caused excess $\mathrm{NH}_{4}{ }^{+}$export from a North Carolina agricultural wetland. Most research to date on biogeochemical and ecosystem $\mathrm{C}$ cycling as a result of saltwater intrusion into coastal wetlands has focused on laboratory experiments (Weston et al. 2006, Chambers et al. 2011, Weston et al. 2011), mesocosm manipulations (Chambers et al. 2013, Wilson et al. in review), or natural salinity gradients (Craft et al. 2009, Giblin et al. 2010, Weston et al. 2014, Wilson et al. 2015, Whittle and Gallego-Sala 2016). Very few salinity manipulations have been conducted in the field (Neubauer 2013), but since scale often matters to results-interpretation, in situ manipulations are desirable for interpreting mechanisms of change inferred from smaller-scale/benchtop experiments or larger-scale descriptive studies.

Our objective was to test ecosystem responses to pulses of elevated salinity in both freshwater and brackish peat marshes in the coastal Everglades. We experimentally elevated in situ porewater salinity to twice-ambient levels using monthly pulsed deliveries to surface waters of brackish and freshwater marshes. We measured $\mathrm{C}$ fluxes (as $\mathrm{CO}_{2}$ and $\mathrm{CH}_{4}$ ), above- and below-ground Cladium jamaicense (sawgrass) biomass and production, and porewater biogeochemical constituents, to understand critical process changes in ecosystem function. We hypothesized that (1) prolonged exposure to pulsed salinity increases would alter belowground biogeochemical cycling and reduce 
NEP in freshwater and brackish peat marshes; (2) the decline in NEP contributes to net soil C loss and less sawgrass fine root production; (3) C loss from the soil will be amplified during conditions of seasonal dry-down and/or drought; and (4) the FW marsh will be more sensitive to saltwater intrusion than the BW marsh and would therefore have higher magnitude responses to the elevated salt treatment.

\section{MATERIALS AND METHODS}

\section{Study Sites and Experimental Design}

This study was conducted in Everglades National Park, Florida, USA along the southeastern boundary of Shark River Slough, the largest drainage boundary in the southern Everglades. The coastal Everglades range along a gradient from freshwater sawgrass ridge and sloughs to coastal mangrove forests. We chose two sites for our study: a brackish marsh that was already experiencing saltwater intrusion, and a freshwater marsh that, to our knowledge, had not experienced elevated salinity. The brackish marsh $\left(25^{\circ} 13^{\prime} 13.17^{\prime \prime} \mathrm{N}, 80^{\circ} 50^{\prime} 36.96 ” \mathrm{~W}\right)$ was dominated by Cladium jamaicense (sawgrass) sparsely interspersed with Conocarpus erectus (buttonwood). The site was non-tidal and characterized by distinctive wet-dry hydrologic regimes in which the site was flooded for $\sim 8$ months of the year (mean since 2000, EDEN gauge NMP). The freshwater marsh $\left(25^{\circ} 26^{\prime} 07.77^{\prime \prime} \mathrm{N}, 80^{\circ} 46^{\prime} 51.50^{\prime \prime} \mathrm{W}\right)$ was co-dominated by sawgrass and Eleocharis cellulosa (spikerush) but also contained other freshwater marsh plants such as Crinum americanum (swamp lily), Bacopa monnieri (waterhyssop), and Panicum hemitomon (maidencane). The hydrologic regime at the site was characterized as long- 
hydroperiod, flooded nearly year-round ( $\sim 11$ months, mean since 2000, EDEN gauge NP62) during a typical year. The soil properties of each site can be found in Table 1. In September 2014, 16 plots were established at each site along an 80-m long constructed boardwalk (Fig. 1). In twelve plots, we installed 1.4-m diameter, 0.4-m tall clear, cylindrical, polycarbonate chamber by inserting them $30-\mathrm{cm}$ into the soil. We designated 4 additional plots as "no-chamber" controls and had no chamber installed around them. Each chamber had a movable collar with a series of 10-cm diameter holes that could be closed during application of dosing water and open to natural flow during all other times. Six ambient water addition (“+AMB") plots were established upstream from natural water flow, while 6 treatment (+saltwater, “+SALT”) plots were established downstream of natural flow to avoid salt contamination into the +AMB and "nochamber" control plots. The 4 "no-chamber" controls, which were interspersed within the +AMB plots (Fig. 1), did not receive water additions, and were only used for C flux measurements (see below). A 3-m "buffer zone" was established to avoid contamination between salt-dosing and control plots.

\section{$\underline{\text { In Situ Saltwater Additions }}$}

Experimental water additions began in October 2014 and were conducted monthly for two years. The volume and salinity of brine solution mixed to deliver our dose varied for each dosing month to reach porewater concentration target. The volume and salinity of the brine solution was calculated on the basis of both water height from soil surface and surface water salinity so that we could reach an elevated salinity target in the porewater salinity, $2-5 \mathrm{ppt}$ at the freshwater and $20 \mathrm{ppt}$ at the brackish site. Our brine 
solution during dosing ranged from 30.7-65.0 ppt at the FW site and 26.8-68.0 ppt at the BW site (Stachelek et al. in review). The dosing solution was prepared from a mixture of source water obtained either at or near each study site in combination with commercially available sea salt mix (Instant Ocean ${ }^{\circledR}$; Atkinson and Bingman 1997).

A movable collar on the chambers was used to close the chambers while dosing to ensure that the dosing water remained within the chamber. Doses were delivered from elevated boardwalks running alongside each chamber using a submersible bilge-style pump (Xylem Inc, USA). The outlet hose was fitted with a spreader device that split the large output stream into six smaller streams. The design was intended to maximize mixing with ambient site water while minimizing disturbance to sensitive benthic periphyton. Emergent plants were briefly sprayed with freshwater following dosing to avoid potential damage from direct salt application. Chambers remained closed for 24 hours to allow the elevated-salinity water to penetrate into the porewater, then chambers were opened to prevent closure artifacts.

\section{$\underline{\text { Soil and Water Chemistry }}$}

Porewater salinity and nutrient measurements were made from three sampling wells ("sippers") placed randomly inside each chamber to a depth of $15-\mathrm{cm}$. Porewater salinity was measured 24 and 120 hours after dosing. Two sippers were installed $0.5-\mathrm{m}$ outside the edge of each chamber to monitor any potential leakage of saltwater outside of the treatment plots. Samples for nutrient and carbon analyses were collected $24 \mathrm{~h}$ after dosing. From each sipper, a $\sim 25-\mathrm{mL}$ sample was extracted after purging the length of tubing, and temperature, salinity, and $\mathrm{pH}$ were measured immediately in the field (YSI 
Model 600 XL, Yellow Springs, OH). The porewater from each of the three wells was then combined into one sample per chamber, field filtered $(0.7 \mu \mathrm{m} \mathrm{GF} / \mathrm{F})$, transferred to new, single use bottles, stored at $4^{\circ} \mathrm{C}$, and analyzed within $21 \mathrm{~d}$.

Surface water salinity was collected from each plot during wet periods by collecting $140-\mathrm{mL}$ of sample water and processing it the same as we processed porewater. Surface water temperature, salinity, and $\mathrm{pH}$ were measured immediately in the field (YSI). Soluble reactive phosphorus (SRP) and total dissolved P (TDP) were analyzed at the South Florida Water Management District Analytical Research Laboratory on an Alpkem Flow Solution Analyzer (OI Analytical, College Station, TX, USA) following Standard Method 4500-P F (SRP) and Solorzano and Sharp (1980, TDP). Ammonium $\left(\mathrm{NH}_{4}{ }^{+}\right)$, and dissolved inorganic $\mathrm{N}(\mathrm{DIN})$ were analyzed at the South Florida Water Management District Water Quality Laboratory on a Lachat Flow Injection Analyzer (Lachat Instruments, Loveland, CO, USA) following Standard Method 4500NH3 H $\left(\mathrm{NH}_{4}{ }^{+}\right)$or Standard Method 4500-N C (DIN). Dissolved organic C (DOC) was analyzed using a Shimadzu TOC-L analyzer (Shimadzu Scientific Instruments, Columbia, MD, USA) following Standard Method 5310 B. Alkalinity and pH were determined using an automated titrator (Metrohm 855 Titrator, Herisau, Switzerland) following Standard Method 2320 B (Alkalinity) and a modification to Standard Method $4500 \mathrm{H}^{+} \mathrm{B}(\mathrm{pH})$. Chloride $\left(\mathrm{Cl}^{-}\right)$and sulfate $\left(\mathrm{SO}_{4}{ }^{2-}\right)$ were measured using a Metrohm 881 Compact IC Pro System (Metrohm, Riverview, FL, USA) following Standard Method 4110 B. Sulfide (HS') was measured using standard methods (McKee et al. 1988). Soil redox potential was measured using standard techniques (Faulkner et al. 1989). Briefly, three platinum-tipped probes were inserted to $15-\mathrm{cm}$ depth in each plot and allowed to 
equilibrate for 30 minutes before measurement. Soil bulk density was determined by taking one $2.4-\mathrm{cm}$ diameter core down to $30-\mathrm{cm}$. Samples were dried at $60^{\circ} \mathrm{C}$ and weighed to calculate dry bulk density $\left(\mathrm{g} \mathrm{cm}^{-3}\right)$.

\section{$\underline{\text { Species Richness, Culm Density, and Above- and Below-ground Biomass }}$}

Aboveground vegetation at each site was measured bimonthly using a nondestructive technique (Daoust and Childers 1998). Briefly, ten sawgrass plants per plot were tagged and turnover was determined from the change in the number of live and dead leaves. Within each plot during each sampling period, fifteen sawgrass plants were randomly chosen for number of leaves, height of the longest leaf, and culm diameter measurements. Average aboveground sawgrass biomass was then calculated using previously generated allometric equations (Childers et al. 2006). Sawgrass leaves were sampled yearly by collecting the youngest mature leaf from 3 randomly selected culms in each plot. They were then dried $60^{\circ} \mathrm{C}$ and ground before analysis for $\mathrm{C}$, nitrogen $(\mathrm{N}$; Zimmermann and Keefe 1997), and phosphorus (P; Solorzano and Sharp 1980) content. Macrophyte species richness was estimated by identifying and recording the genus and species of each plant type within each plot.

Live belowground root biomass was obtained by taking three $2.4-\mathrm{cm}$ diameter soil cores from each plot at the end of year 2 (October 2016). Each core was taken to 30-cm depth, extruded, separated into 10 -cm depths, and stored at $4^{\circ} \mathrm{C}$ until analysis (within 1 week). In the lab, the core segment was placed over a 1-mm sieve and washed with a constant stream of water. Live roots, those which floated when submerged in water, were separated from dead roots and peat, dried at $60^{\circ} \mathrm{C}$, and weighed. 


\section{Ecosystem Carbon Flux}

Within each plot, one $0.5 \times 0.5 \mathrm{~m}$ polycarbonate collar was permanently installed 10-cm into the soil and extended 5-cm above the soil surface for ecosystem C flux measurements. Each collar had eight 2.5 -cm diameter holes at soil surface level to allow for natural flow of water when measurements were not occurring. Plot-scale $\mathrm{CO}_{2}$ exchange was measured monthly using a transparent static chamber $\left(0.25 \mathrm{~m}^{2} \times 1.5 \mathrm{~m}\right.$; after Neubauer et al. 2000, Wilson et al. 2015). Prior to measurements being taken, each hole in the collar was plugged with a rubber stopper, the chamber was placed into a lip in the collar and sealed, and the system was allowed to equilibrate for 2 minutes. Measurements were then made for 3 minutes each in full light and in the dark, with the chamber lid removed in between each measurement to allow the chamber to return to atmospheric conditions (LI-COR 840, Lincoln, NE; Wilson et al. in review). All measurements made at each site were taken within \pm 3 hours of solar noon and on the same day. Missing measurements occurred when there was either equipment failure (BW site, Jul - Aug 2016) or when water levels were higher than the boardwalk (FW site, Dec 2015 - Apr 2016), limiting access to the plots.

Methane $\left(\mathrm{CH}_{4}\right)$ exchange measurements were conducted monthly from October 2014 - February 2016. After the dark $\mathrm{CO}_{2}$ exchange measurement was conducted, the chamber was kept in the dark and resealed for 20 minutes. Air from the chamber was continually pumped through a closed loop with a sampling port attached. Gas samples were taken 0,10 , and 20 minutes using a $60-\mathrm{mL}$ syringe to withdraw $25-\mathrm{mL}$ of air from the sampling port placed in line with the chamber. The sample was then injected into a 20-mL evacuated vial. Methane concentrations were determined using a gas 
chromatograph (Hewlett-Packard 5890, Palo Alto, CA, USA), and the change in concentration over time was used to calculate the flux.

Soil respiration was measured using one $10-\mathrm{cm}$ diameter collar installed $5-\mathrm{cm}$ into the soil surface within each plot at each site to be taken during dry-down. Soil $\mathrm{CO}_{2}$ efflux was measured over one 1-day period in February 2015 when water receded below the soil surface; it was measured for 120 seconds using a portable infrared gas analyzer (LI-COR 8100, Lincoln, NE, USA). Soil $\mathrm{CO}_{2}$ efflux was not measured during other dry months because of equipment failure.

\section{$\underline{\text { Statistical Analyses }}$}

The difference in biogeochemical variables $\left(\mathrm{Cl}^{-}, \mathrm{SO}_{4}{ }^{2-}, \mathrm{NH}_{4}{ }^{+}, \mathrm{TDN}, \mathrm{DOC}, \mathrm{SRP}\right.$, TDP, HS, alkalinity, and $\mathrm{pH}$ ), gas flux (GEP, $\mathrm{ER}_{\mathrm{CO} 2}, \mathrm{ER}_{\mathrm{CH} 4}, \mathrm{NEP}$, soil $\mathrm{CO}_{2}$ efflux), culm density, and sawgrass biomass (above- and below-ground) among control, elevated salinity, ambient water dosing experimental plots were evaluated using linear mixed models (Package "nlme", Pinheiro et al. 2017). Treatment and date were fixed factors, while plot was a random factor. Because hydrology highly influenced fluxes at the site, analyses for gas fluxes were performed separately when each site was wet (water covering soil surface) and dry (water below soil surface). A one-way ANOVA was used to compare differences in plant stoichiometry across treatments and sites. All linear mixed models were assessed for temporal differences using the least squared means (LSMEANS), with date as a model effect (R package lsmeans, Lenth 2017). All ANOVA analyses were sub-tested with Tukey's post-hoc test to see differences among treatments. Differences in total belowground biomass, soil $\mathrm{CO}_{2}$ efflux, and macrophyte species 
richness were determined using an independent $t$-test. Normality and homoscedasticity were tested by visually inspecting plotted residuals, and data were log-transformed to increase heteroscedasticity when necessary. All of the above analyses were performed in $\mathrm{R}$ ( $\mathrm{R}$ core team 2017). A piecewise regression with 200 iterations was used to determine change-points in ambient porewater salinity at the BW site using Sigmaplot 13.0 (Systat Software Inc., San Jose, CA). All analyses were tested with $\alpha=0.10$ because of the high within-site variability and because it was logistically unfeasible to increase replication power (Neubauer 2013). Therefore, type I errors (incorrectly rejecting the null hypothesis) are more likely than if a more conservative alpha value of 0.05 was used (Neubauer 2013).

\section{RESULTS}

Water Chemistry

Porewater salinity and chemistry at the FW and BW sites were measured 24-hours after dosing. Porewater salinity in the +SALT plots at the FW site ranged from $1.50 \pm$ 0.29 to $4.56 \mathrm{ppt} \pm 0.30$ (mean \pm SE; Fig. $2 \mathrm{c}$ ) and was $2.39 \pm 0.15 \mathrm{ppt}$ higher compared to ambient fresh conditions (+AMB plots). Porewater salinity, $\mathrm{pH}, \mathrm{SO}_{4}{ }^{2-}, \mathrm{NH}_{4}{ }^{+}$, and TDN increased with added salinity, while porewater DOC decreased ( $P<0.10 ;$ Fig. 2$)$. There was no change in temperature, alkalinity, SRP, and TDP with added salinity $(P>0.10$; Fig. 2). At the BW site, porewater salinity in the + SALT plots ranged from $11.24 \pm 0.43$ to $19.37 \mathrm{ppt} \pm 0.25$ (Fig. 2d). On average, porewater salinity was $4.71 \pm 0.40 \mathrm{ppt}$ higher in the +SALT plots compared to the +AMB plots. Porewater salinity and $\mathrm{SO}_{4}{ }^{2-}$ increased with added salinity, while alkalinity, DOC, $\mathrm{NH}_{4}{ }^{+}$, TDN, SRP, and TDP all decreased 
with added salinity (Table $2 ; P<0.10$ ). Porewater SRP and TDP were $1-2$ orders of magnitude higher at the BW site compared to the FW site.

Ambient porewater salinity at the BW site changed distinctly over the study period, elevating from $8.0 \pm 0.3 \mathrm{ppt}$ (Oct 2014) to $12.0 \pm 0.4 \mathrm{ppt}$ (Oct 2016; Fig. 3).

Distinct change-points were detected using a 3-way piecewise regression $\left(r^{2}=0.943\right.$, $\left.F_{(7,24)}=40.46, P<0.001\right)$ and corresponded with periods where water receded below or rose above the soil surface (Fig. 3). Mean salinity of each change-point can be found in Table S1.

Porewater $\mathrm{HS}^{-}$was two orders of magnitude higher at the $\mathrm{BW}$ site compared to the FW site (Fig. 4). At the FW site, porewater $\mathrm{HS}^{-}$was undetectable in the $+\mathrm{AMB}$ plots and elevated in the + SALT plots $(0.08 \pm 0.01 \mathrm{mM} ; P<0.001)$. At the $\mathrm{BW}$ site, porewater $\mathrm{HS}^{-}$was lower in the + SALT plots compared to the + AMB plots $(1.20 \pm 0.12$ vs. $2.88 \pm$ $0.12 \mathrm{mM} ; P<0.001)$. There was no difference in redox potential between the $+\mathrm{AMB}$ and + SALT plots at the FW site (Fig. S2; $P=0.252$ ). At the BW site, redox potential was significantly higher in the +SALT plots compared to the +AMB and "no-chamber" control plots (Fig. S2; $P<0.001)$.

\section{$\underline{\text { Species Richness, Culm Density, and Above- and Below-ground Biomass }}$}

There was no difference in E. cellulosa stem density between the +AMB (185 \pm 23 plants plot $\left.^{-1}\right)$ and $+\operatorname{SALT}\left(152 \pm 21\right.$ plants plot $\left.^{-1}\right)$ plots at the FW site $(P>0.10)$. Macrophyte species richness at the FW site was not significantly different between the $+\mathrm{AMB}$ and $+\mathrm{SALT}$ treatments during the first year $\left(4.1 \pm 0.3\right.$ vs. $4.3 \pm 0.2$ species plot $^{-1}$, respectively); however, + SALT plots had fewer species per plot $(2.9 \pm 0.2)$ compared to 
the $+\mathrm{AMB}$ treatment after the second year of dosing $(3.8 \pm 0.3 ; t=3.77, P<0.001)$.

Sawgrass leaf nutrient stoichiometry response to salt dosing varied by site (Table 3 ). At both sites, sawgrass $\mathrm{C}$ concentration did not change with saltwater addition (ANOVA, $P>0.10$ ). At the BW site, both sawgrass leaf $\mathrm{N}$ and $\mathrm{P}$ increased with added salinity after both 1 and 2 years (Table 3). Both sawgrass leaf $\mathrm{N}$ and $\mathrm{P}$ at the FW site were similar across treatments.

At the FW site, saltwater additions caused no change in sawgrass culm density or aboveground biomass after two years ( $\mathrm{p}>0.10$; Table 4, Fig. 5). At the BW site, there was a delayed response. Sawgrass culm density in the +SALT plots did not significantly differ from the + AMB plots until Oct 2016 (LSMEANS, $t=2.51, P=0.030$ ), two years after saltwater additions began. Similarly, we found no significant difference in aboveground biomass in +SALT plots until Dec 2016 (LSMEANS, $t=2.27, P=0.046$; Fig. 5a). ANPP was depressed in the second year at the BW site in the +SALT plots (307 \pm $\left.101 \mathrm{gdw} \mathrm{m}^{-2}\right)$ compared to the +AMB plots $\left(504 \pm 146 \mathrm{gdw} \mathrm{m}^{-2}\right)$, but this effect was not significant $(P>0.10 ;$ Fig. 6$)$. There was no change in ANPP with salt addition at the FW site $(P>0.10)$. Sawgrass culm density, aboveground biomass, and ANPP were less at the FW site compared to the BW site; however, the effect was not significant with ANPP.

Two years after saltwater dosing was initiated, live belowground biomass at both sites decreased. At the BW site, live root biomass declined at all depths with added salinity $\left(F_{(1,30)}=6.69, P=0.014\right)$, but this result was only significant in the top 10-cm and when all three depths were combined (Tukey HSD, $P<0.10$; Table 5). At the FW site, live root biomass declined at all depths with added salinity $\left(F_{(1,30)}=13.99, P<0.001\right)$, but this result was only significant in the top $10-\mathrm{cm}$ and when all three depths were combined 
(Tukey HSD, $P<0.10$; Table 5). There was no significant difference in live root biomass at 0-10 and 10-20 cm depths when comparing between the FW + AMB and the BW +AMB plots, yet the BW site had less live root biomass compared to the FW site at the 20-30 cm depth horizon $(t=22.0, P=0.004)$ and with all combined depths $(t=260.0$, $P=0.022$; Table 5).

\section{Ecosystem Carbon Flux}

There was no difference between the "no-chamber" control and the +AMB plots for every flux measurement and on every date $(P>0.10$; Table 6$)$. Therefore, we only compare the results between the $+\mathrm{SALT}$ and $+\mathrm{AMB}$ plots. Rates of $\mathrm{ER}_{\mathrm{CO} 2}$ and NEP had seasonal patterns at both sites (Fig. 7) directly related to inundation, with each site taking up $\mathrm{CO}_{2}$ when inundated, but releasing $\mathrm{CO}_{2}$ when water receded below the soil surface. $\mathrm{ER}_{\mathrm{CO} 2}$ was directly correlated with water level, maxing out at $6.7 \mu \mathrm{mol} \mathrm{CO}_{2} \mathrm{~m}^{-2} \mathrm{~s}^{-1}(\mathrm{BW}$, +SALT, Jul 2015) and $10.8 \mu \mathrm{mol} \mathrm{CO} \mathrm{C}^{-2} \mathrm{~s}^{-1}(\mathrm{FW},+\mathrm{AMB}, \mathrm{Apr} 2015)$ at each site when soil was exposed (Fig. 7). Overall, $\mathrm{ER}_{\mathrm{CO} 2}$ was greater (ANOVA, $P<0.10$ ) when soil was exposed at each site (Table 6).

At the FW site, added salt caused a reduction in NEP, GEP, and $\mathrm{ER}_{\mathrm{CO} 2}(P<0.10$; Table 4) when the site was inundated, though this result was strongly time-dependent and occurred only for three months following dry-down (Fig. 7). There were no effects of elevated salinity on NEP, GEP, and $\mathrm{ER}_{\mathrm{CO} 2}$ when the site $\mathrm{FW}$ was dry $(P>0.10$; Table 6). When soil at the FW site was exposed, added salt caused greater $\mathrm{ER}_{\mathrm{CH} 4}$, however, because of high variability and lack of months in which the soil was exposed during drawdown, this result was not significant over the duration of the experiment $(P>0.10)$. 
Soil $\mathrm{CO}_{2}$ efflux during May 2015 was higher in the $+\mathrm{AMB}$ plots compared to the + SALT

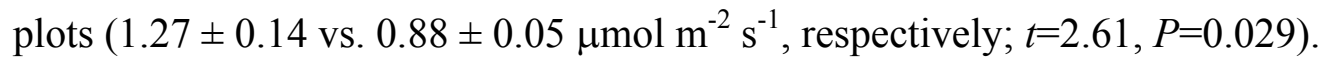

At the BW site, added salt had no effect on NEP, GEP, $\mathrm{ER}_{\mathrm{CO} 2}, \mathrm{ER}_{\mathrm{CH} 4}$, and soil $\mathrm{CO}_{2}$ efflux $(P>0.10$; Table 4) when the site was wet (Table 6). When soil at the BW site was exposed, there was no difference between treatments $(P>0.10)$ in GEP, $\mathrm{ER}_{\mathrm{CO} 2}$, and $\mathrm{ER}_{\mathrm{CH} 4}$ flux, but added salt decreased NEP (more $\mathrm{CO}_{2}$ released) compared to the "nochamber" control and $+\mathrm{AMB}$ plots $\left(P=0.008\right.$; Table 6). Soil $\mathrm{CO}_{2}$ efflux during February 2015 was lower in the + AMB plots compared to the + SALT plots $(0.60 \pm 0.08$ vs. $0.96 \pm$ $0.10 \mu \mathrm{mol} \mathrm{m}{ }^{-2} \mathrm{~s}^{-1}$, respectively; $\left.t=2.55, P=0.031\right)$.

\section{DISCUSSION}

Salinity pulses significantly changed porewater biogeochemistry and the net soil C balance. Hydrology (i.e., seasonal dry-down) was an important factor that interacted with salinity pulses to influenced NEP. Pulses of elevated salinity reduced NEP at the FW marsh following a dry-down event, while elevated salinity only changed ecosystem $\mathrm{CO}_{2}$ flux from the BW marsh during dry-down conditions. The decline in live root biomass at both sites under conditions of elevated salinity reflected reduced organic matter inputs into the soil and/or increased turnover of live to dead roots. These results confirmed our hypotheses that pulses of elevated salinity water would change biogeochemical cycling and decrease plant root production and NEP, though the effect was site-dependent. We also confirmed that $\mathrm{C}$ loss was amplified during dry-down conditions at the BW site. We found that, even under ambient conditions, the BW marsh was a net $\mathrm{CO}_{2}$ source to the atmosphere, a potential mechanism for the collapse of peat 
observed at the site. Here we provide some of the first evidence of biogeochemical responses to simulated saltwater intrusion from non-tidal, coastal peat marshes.

\section{Biogeochemical response to salinity pulses}

Porewater chemistry varied dramatically by site in response to saltwater additions. Elevated salinity increased porewater $\mathrm{SO}_{4}{ }^{2-}$ at both the $\mathrm{FW}$ and $\mathrm{BW}$ sites as the brine solution we applied to the marshes contained $\mathrm{SO}_{4}{ }^{2-}$ concentrations mimicking those found in seawater. Elevated porewater $\mathrm{SO}_{4}{ }^{2-}$ with saltwater intrusion has been shown to greatly influence marsh biogeochemical cycling. Under anaerobic conditions the addition of $\mathrm{SO}_{4}{ }^{2-}$ encourage the sufate-reducing bacteria to outcompete methanogens, given the higher energy yield that comes with using $\mathrm{SO}_{4}{ }^{2-}$ as the terminal election acceptor (Delaune et al. 1983, Burdige 2006). Enhanced $\mathrm{SO}_{4}{ }^{2-}$ reduction usually depresses $\mathrm{CH}_{4}$ efflux and can initially stimulate soil $\mathrm{CO}_{2}$ efflux (Chambers et al. 2011, Poffenbarger $e t$ al. 2011, Wilson et al. in review). We did not see a significant suppression in $\mathrm{CH}_{4}$ efflux at either the FW or BW site, most likely because of the high variability among measurements and our inability to detect episodic ebullition flux at a monthly sampling frequency (Goodrich et al. 2011, Comas and Wright 2012, 2014). We expected $\mathrm{CH}_{4}$ efflux to be much higher at the FW compared to the BW site based on higher salinity (Poffenbarger et al. 2011), but we saw little difference between the two sites (Table 6). High water levels during measured flux could have allowed $\mathrm{CH}_{4}$ diffused from the soil into the overlying water column to be oxidized (Megonigal and Schlesinger 2002, Reddy and DeLaune 2008), and therefore, we may not have a true estimate of $\mathrm{CH}_{4}$ production at our sites. Additionally, $\mathrm{CH}_{4}$ efflux was likely not higher at the $\mathrm{FW}$ site because previous 
work in the oligotrophic Everglades suggest that $\mathrm{P}$ limitation could be influencing $\mathrm{CH}_{4}$ production (Amador and Jones 1993). Because of the long hydroperiods at our sites, they were covered with water at the outset of our study so we were not able to measure initial soil $\mathrm{CO}_{2}$ efflux. Instead, soil $\mathrm{CO}_{2}$ flux was measurable only when water receded below the soil surface (dry-down in Feb 2015; Fig. 7). During this time, with pulses of elevated salinity water, soil $\mathrm{CO}_{2}$ efflux decreased at the FW site. This was most likely the result of microbial stress combined with more oxic conditions suppressing sulfate reduction and stimulating aerobic metabolism to the point where elevated $\mathrm{SO}_{4}{ }^{2-}$ from saltwater addition would not stimulate sulfate reduction (Mitsch and Gosselink 2007, Weston et al. 2011). Conversely, elevated salinity stimulated soil $\mathrm{CO}_{2}$ efflux at the $\mathrm{BW}$ site. The same result was seen briefly for a period of approximately one week in mesocosm experiments using soil harvested at the BW site when they were exposed to elevated salinity and dry-down conditions (Wilson unpublished data). Therefore, although pulses of elevated salinity coupled with dry-down may initially stimulate soil $\mathrm{CO}_{2}$ efflux, this stimulatory effect may not persist.

Porewater $\mathrm{NH}_{4}{ }^{+}$and TDN increased with added salinity at the FW site, possibly as a result of cations from the saltwater mix replacing adsorbed cations in soils such as $\mathrm{NH}_{4}{ }^{+}$(Gardner et al. 1991, Ardon et al. 2013). Contrary to expectation, porewater alkalinity, $\mathrm{DOC}, \mathrm{NH}_{4}{ }^{+}, \mathrm{TDN}, \mathrm{SRP}, \mathrm{TDP}$, and $\mathrm{HS}^{-}$all decreased at the BW site with saltwater addition. Saltwater intrusion into coastal wetlands can happen from both aboveground pulses, such as tides or storm surges, or from belowground press factors, such as SLR and seasonal dry-down (Herbert et al. 2015). The biogeochemical response to each saltwater intrusion mechanism may also vary in a similar fashion. In our study, 
there is evidence to suggest that lower porewater nutrient concentrations in the +SALT plots at the BW site may be caused by saltwater cation replacement. Our brine dosing solution mimicked the ionic composition of seawater, which is high in cations and is known to displace other cations adsorbed to soils, such as $\mathrm{NH}_{4}{ }^{+}$and dissolved inorganic P (Gardner et al. 1991, Seitzinger et al. 1991, Fourqurean et al. 1992, Price et al. 2006). These minerals, now bioavailable, could have been taken up by macrophytes or microbes and incorporated into their biomass. Higher sawgrass leaf $\mathrm{N}$ and $\mathrm{P}$ content at our $+\mathrm{SALT}$ plots at the BW site compared to the $+\mathrm{AMB}$ plots corroborates this hypothesis. Higher leaf nutrient content within the +SALT plots could have also been caused by microbial cell death and lysis from excess salt, which would release nutrients and organic molecules into the surrounding porewater (Gobler et al. 1997) that can be taken up by the plants. This nutrient release could provide a temporary subsidy for brackish marsh plants to survive despite their relatively high-salinity and high-stress environments. More studies are needed to confirm this mechanism.

\section{Ecosystem C cycling}

Hydrology has been shown to strongly regulate exchange of $\mathrm{CO}_{2}$ between the land and atmosphere in wetlands (Hao et al. 2011, Jimenez et al. 2012, Malone et al. 2013, Malone et al. 2014). The marshes we studied exhibited similar patterns of $\mathrm{CO}_{2}$ flux in response to dry-down as other long-hydroperiod Everglades marshes by acting as a net $\mathrm{CO}_{2}$ sink when water covered the soil surface and a net $\mathrm{CO}_{2}$ source when water fell below the soil surface (Jimenez et al. 2012, Schedlbauer et al. 2012, Malone et al. 2014). During periods in which water was covering the soil surface, $\mathrm{ER}_{\mathrm{CO} 2}$ was low and 
maximum potential GEP was high at both sites, leading to net $\mathrm{CO}_{2}$ uptake at solar noon (Fig. 7). However, during periods when water receded below the soil surface, $\mathrm{ER}_{\mathrm{CO} 2}$ spiked, as previous work illustrated higher aerobic respiration stimulation as a result of increased soil oxidation (Mitsch and Gosselink 2007, Webster et al. 2013), and these marshes switched from $\mathrm{CO}_{2}$ sinks to net $\mathrm{CO}_{2}$ sources to the atmosphere. GEP at our marsh sites was not affected during drought. Malone et al. (2013) saw a similar response in GEP and $\mathrm{ER}_{\mathrm{CO} 2}$ in a sawgrass marsh when exposed to dry-down conditions. To control for the addition of water in our + SALT plots, we added the same volume of ambient salinity water to our $+\mathrm{AMB}$ plots and took measurements on "no-chamber" control plots in which no water was added. We saw no difference in any flux measurements between the $+\mathrm{AMB}$ and no water-added control plots during either the wet or dry period (Table 6), meaning that the physical act of adding more water to the plot during dosing had no measureable effect. This was likely because the amount of ambient water we added to each plot $(<200 \mathrm{~L})$ was not enough to substantially raise water levels and affect GEP by decreasing exposed leaf area (Schedlbauer et al. 2010, Jimenez et al. 2012), and because water was already covering the surface, additional water dosing would not decrease $\mathrm{ER}_{\mathrm{CO} 2}$, as seen in freshwater tidal marshes (Neubauer 2013).

Elevated salinity in coastal wetlands has been shown to alter ecosystem $\mathrm{CO}_{2}$ cycling between the marsh and the atmosphere (Neubauer 2013, Weston et al. 2014). Our marsh sites responded differently to added salinity when water receded below the soil surface. When the marsh was wet, there was no effect on $\mathrm{CO}_{2}$ flux with the addition of salinity, but when water receded below the soil surface, added salinity reduced NEP at the BW site (Table 6). Although mean GEP fell and mean $\mathrm{ER}_{\mathrm{CO} 2}$ rose during dry-down in 
the added salinity plots at the BW site, these rates were not significantly different from the + AMB plots. NEP, however, was significantly greater in a negative direction, indicating that added salinity caused more $\mathrm{CO}_{2}$ to be released to the atmosphere. The rise in $\mathrm{ER}_{\mathrm{CO} 2}$ with added salinity can be attributed to an increase in soil $\mathrm{CO}_{2}$ efflux as oxidation of wetland soils generally enhances microbial respiration (Crow and Wieder 2005). Although we only have one month of soil $\mathrm{CO}_{2}$ efflux measurements (Feb 2015), efflux increased by $0.35 \pm 0.09 \mu \mathrm{mol} \mathrm{CO} \mathrm{CO}^{-2} \mathrm{~s}^{-1}$ with added salinity compared to the $+\mathrm{AMB}$ plots, while during the same month, $\mathrm{ER}_{\mathrm{CO} 2}$ increased by $0.51 \pm 0.31 \mu \mathrm{mol} \mathrm{CO}_{2} \mathrm{~m}^{-}$ ${ }^{2} \mathrm{~s}^{-1}$ with added salinity (Fig. 7e). Weston et al. (2011) measured a similar increase in soil $\mathrm{CO}_{2}$ efflux with added salinity $\left[0.60\right.$ (control) vs 0.71 (+salt) $\left.\mu \mathrm{mol} \mathrm{CO}_{2} \mathrm{~m}^{-2} \mathrm{~s}^{-1}\right]$ when tidal freshwater marsh soils were exposed.

Gross ecosystem productivity at the BW site also declined with added saltwater when no surface water was present (Fig. 7d). This response was a physiological effect because there was no significant decrease in biomass during this period (Fig. 5). Sulfide toxicity is a common stressor for wetland plants experiencing saltwater intrusion (Lamers et al. 1998). Lower sulfide and higher redox conditions in the +SALT plots at the BW site suggests that the plants were likely responding to osmotic stress of salt exposure rather than sulfide toxicity (Fig. 4, Fig. S2). During times of low water availability, salt can accumulate in soils because little water flushes through the marsh (Ardon et al. 2013, Weston et al. 2014). Saltwater addition raised porewater salinities to between 16 and 20 ppt during the period when water was continuously below the soil surface ( $\sim$ Feb to Aug 2015; Fig. 2). High salinity causes osmotic stress, which decreases stomatal conductance and inhibits photosynthesis on rapid timescales (Munns and Tester 2008). Sawgrass has 
been shown to significantly decrease productivity with continuous exposure to $20 \mathrm{ppt}$ salinity (Wilson et al. in review). Because of low water flushing, porewater salinity did not significantly decline between 1 and 5 days after saltwater addition during dry periods, meaning that salinity was maintained at or near levels known to lead to a reduction in NEP (Fig. S1; Wilson et al. in review).

At the FW site, saltwater addition significantly decreased both GEP and $\mathrm{ER}_{\mathrm{CO} 2}$, but only immediately following the dry-down event (Fig. 7a,b). This is a similar response to the decline in both GEP and ER that Neubauer (2013) found with saltwater additions to a tidal freshwater marsh and is expected given that GEP and ER are tightly linked (Cannell and Thornley 2000). Decreased GEP with saltwater after dry-down was likely triggered by dry-down and its legacy effects. Both GEP and ER were lower with added saltwater compared to the + AMB plots for 3 months post-dry-down, resulting in significantly less $\mathrm{CO}_{2}$ uptake with added salt (Fig 7a-c). As little work has been done to study coupled saltwater intrusion and drought effects on coastal wetlands, it is hard to pinpoint the exact mechanisms behind this response. These months (Mar-Aug 2015) were the only time in which porewater salinity at the FW site rose above $4 \mathrm{ppt}$, potentially resulting in osmotic stress and inhibiting stomatal conductance (Fig. 2; Munns and Tester 2008). As water levels rose, the effectiveness of our saltwater dosing diminished and allowed the marsh to recover to pre-dry-down conditions.

\section{Aboveground Biomass}

The salinity tolerance of sawgrass-dominated marshes varies widely and is likely dependent on soil type, hydraulic conductivity, and cation exchange capacity. Sawgrass 
has been shown to be tolerant of annual salinities up to $16.4 \mathrm{ppt}$, but require flushing with lower salinity water (<5 ppt) in order to maintain their productivity (Troxler et al. 2014). Some have shown that sawgrass productivity begins to decrease when exposed to salinities as low as 5 ppt (Macek and Rejmankova 2007), while others have shown that sawgrass does have some tolerance to salinity, and that aboveground biomass and productivity do not significantly decrease until continuous exposure of 20 ppt salinity (Wilson et al. in review). We expected to see a significant decline in sawgrass aboveground biomass with added salinity in the field. However, our results suggest that, aboveground, sawgrass is tolerant to frequent pulses of low-level salinity in freshwater marshes, as there was no decline in aboveground biomass and ANPP. Given that porewater salinity at the FW site never rose above $5 \mathrm{ppt}$, we would not expect to see much, if any, decline in aboveground biomass based on previous studies (Macek and Rejmankova 2007; Wilson et al. in prep). At brackish marshes, however, cumulative salt loading and hydrology appear to impact sawgrass aboveground biomass, GEP, and ANPP (Figs. 5, 7d). At our BW study site, porewater salinity in the +SALT treatment was much higher than the FW site and neared 20 ppt during some months. Because these were pulses of salinity applied monthly rather than continuously, porewater salinity trended downward towards ambient levels 5 days after saltwater was added (Fig. S1). We did observe lower culm density and aboveground biomass with added salinity compared to the +AMB plots toward the end of the 2-year sampling period at the BW site, and a nonsignificant decline in ANPP during the second year, indicating that increased exposure through continued pulses of elevated salinity appear to be having a negative effect on 
sawgrass growth in these brackish conditions, though continued monitoring of increased salinity exposure is needed to confirm this.

\section{$\underline{\text { Peat vulnerability to saltwater intrusion }}$}

In peat marshes that receive little to no sediment input, such as the coastal Everglades, root production and litter turnover is the primary driver of vertical peat accretion (Nyman et al. 2006, McKee 2011, Baustian et al. 2012). We measured a reduction in live root biomass with added salinity at both sites. Little is known about how salt stress reduces initiation of new seminal or lateral roots, although osmotic stress usually reduces cell expansion in root tips (Munns and Tester 2008). Macek and Rejmankova (2007) found that relatively low elevated salinity (4-5 ppt) also decreased sawgrass root biomass. Generally, our BW site had significantly less live root biomass compared to the FW site (Table 5). Given that ambient salinity at the BW site was $\sim 8-12$ ppt and that low levels of porewater salinity $(<5 \mathrm{ppt})$ led to significantly less live root biomass at the FW site, this result was not surprising but has consequences for the future of peat stability. Peat is a matrix of mostly organic matter (typically $>80 \%$; Table 1 ) with high porosity (>85\%; Nyman et al. 1990, Craft et al. 1993, Mitsch and Gosselink 2007). A loss of live roots, and thus the main input of organic matter, could lead to peat destabilization. Deegan et al. (2012) found that N-enrichment in New England salt marshes led to peat destabilization and creek bank erosion, as Spartina alterniflora rootto-shoot allocation declined. Saltwater intrusion as well has been directly related to increased peat decomposition and a decrease in $\mathrm{C}$ accumulation (Whittle and GallegoSala 2016). DeLaune et al. (1994) found that saltwater intrusion caused mass plant 
mortality in a Gulf of Mexico brackish marsh, eventually resulting in peat collapse and conversion of the marsh to open water; the authors attributed this mainly to the loss of the living root network. The loss of the live root network in the peat soil matrix may be one mechanism leading to peat collapse at the BW site, evidenced by live standing sawgrass "pedestals" in which up to $30 \mathrm{~cm}$ of the root matrix is above the current soil surface (Wilson et al. in review).

Marshes should continue to accrete vertically if the amount of $\mathrm{C}$ entering the marsh is higher than amount of C leaving (Nyman et al. 2006, Weston et al. 2014). In non-tidal, non-riverine wetlands that receive little to no external organic matter inputs, such as sediments, estimating the soil $\mathrm{C}$ balance is a robust way to determine if a marsh is accumulating C. We took our instantaneous flux measurements, and, using previously established ecosystem productivity response curves and methods (see Supplemental Methods), we modeled GEP, ER $\mathrm{CO}_{\mathrm{C} 2}$, and NEP to annual flux values (Neubauer 2013, Wilson et al. 2015). We found that NEP at the FW marsh was near C neutral (Fig. 8), which is what has been found at a nearby marsh using an eddy flux tower (Malone et al. 2014). Conversely, we found that the BW site was a large source of C to the atmosphere, even under ambient conditions (Fig. 8). Although not significant, pulses of elevated salinity led to a slight reduction in NEP at the FW site. A decline in live roots and organic matter input into the soil, coupled with a shift from the marsh to a net sink to a net source as it transitions from fresh to brackish, creates conditions that leaves coastal marshes vulnerable to collapse. 


\section{Water management effects on C flux}

Water management decisions can play a critical role in determining how much water enters Everglades National Park (ENP; Light and Dineen 1994, Ross et al. 2003). Because continuous sheet flow through this system has been largely cutoff, periods of seasonal dry-down during low-rainfall years have a strong potential for altering freshwater marsh C cycling (Malone et al. 2014). We predicted that during one of these dry-down events, $\mathrm{C}$ loss from the soil would be amplified with pulses of elevated salinity water. However, our findings supported this hypothesis for the BW site only.

These results raise important questions regarding how seasonal dry-down influences salinity at brackish water marshes and how future saltwater intrusion could alter $\mathrm{C}$ cycling within these marshes. Extreme seasonal dry-down in coastal wetlands, most often a function of altered hydrology, water management, and drought, can (i) increase salinity by reducing flushing and causing salt ion accumulation, (ii) increase the upstream reach of brackish water, and (iii) increase the salinity of tidal water (Anderson and Lockaby 2012, Ardon et al. 2013). In most coastal wetlands, this high salinity pulse is seasonal and returns to ambient levels when flushed by upstream freshwater inputs (Ardon et al. 2013, Weston et al. 2014). However, in the Florida coastal Everglades, surface water flow has been highly modified and is much slower (mean $\sim 1 \mathrm{~cm} \mathrm{~s}^{-1}$; Schaffranek 2004) than most surface flow-dominated wetlands (Light and Dineen 1994). This has reduced porewater flushing (Troxler et al. in press), allowed groundwater upwelling of high salinity water (Price et al. 2006), and contributed to a groundwater salt wedge that continues to move inland in ENP (Saha et al. 2011). Our results suggest that seasonal dry-downs, where the water table falls below the soil surface for an extended 
period of time, may strongly control the ecological response of Everglades coastal wetlands to continued salinization.

Salt can accumulate in soils during seasonal dry-down and drought because little water flushes through the marsh (Ardon et al. 2013, Weston et al. 2014). During a period of low rainfall in early 2015 , ambient porewater salinity at the BW site rose quickly in a 3-month period and maintained near constant higher salinity for the next year despite high rainfall that resulted in high water table levels and low surface water salinity (Fig. 3). This change-point directly coincided with when water dropped below the soil surface. Other change-points occurred every time water rose above or receded below the soil surface. Our results suggest that low rainfall exacerbates conditions of low freshwater delivery to produce extended dry-down and deeper drainage depth - a significant catalyst of change in this coastal Everglades peat marsh.

Coastal groundwater discharge (CGD), when seawater intrudes inland and forces brackish groundwater to discharge vertically into coastal wetlands, is a process that drives ecosystem dynamics in the coastal Everglades (Price et al. 2006, Harvey and McCormick 2009, Troxler et al. 2014). While CGD occurs year-round, seasonal hydrology drives its spatial extent (Dessu et al. 2018). During the wet season, the freshwater aquifer swells and creates a wedge, forcing the area of CGD further towards the coast, but during the dry season, the aquifer shrinks and allows the CGD zone to move more inland and further salinize brackish marshes (Troxler et al. in press). Within the Everglades, there is ample evidence in Taylor Slough of seasonal wetland salinization during the dry season (Troxler et al. in press) but less evidence from Shark River Slough (SRS), the location of our study. Price et al. (2006) showed no evidence of CGD within 
SRS, but the wells sampled in this study were along a river and tidally influenced. However, CGD with salinities of $\sim 25$ ppt has been measured at West Lake, $1 \mathrm{~km}$ from our BW study site (Joshua Allen, Florida International University, unpublished data). Groundwater salinity of $5.5 \mathrm{ppt}$ has also been measured at Nine Mile Pond, $5.9 \mathrm{~km}$ inland from our site (J. Allen, unpublished data). Therefore, it is likely that CGD strongly controls porewater salinity at these brackish marshes, especially during exceptionally dry periods, such as drought. While some predictions about how climate change will affect drought frequency are contradictory (Sheffield et al. 2012, Dai 2013), it is predicted that droughts will set in quicker and become more intense (Trenberth et al. 2014). Both CERP and the Central Everglades Planning Project aim to increase water flow to the coastal Everglades and could potentially mitigate the effects of drought by keeping coastal marshes inundated for longer periods. Without this restoration, periods of drought could further salinize these brackish marshes, cause more $\mathrm{C}$ to be released to the atmosphere (Fig. 8), and result in peat collapse and transformation of marsh into open water.

\section{ACKNOWLEDGEMENTS}

Funding for research was supported by Florida Sea Grant R/C-S-56, including cooperative agreements with the South Florida Water Management District, the Everglades Foundation, and Everglades National Park. Additional funding was provided through the National Science Foundation's Florida Coastal Everglades Long Term Ecological Research Program (DEB-1237517). We thank Shawn Abrahams, Michelle Blaha, Marbelys Garriga, Adam Hines, Rowan Johnson, Oliver Ljustina, Melinda Martinez, Fabiola Santamaria, Chris Sillivan, Frank Skiff, Emily Standen, Ryan Stolee, 
and Mary Grace Thibault for help in the field. Len Scinto graciously provided lab resources for methane flux analysis. Joshua Allen provided descriptive details on coastal groundwater discharge in the coastal Everglades. Steve Oberbauer provided valuable feedback on early drafts of this manuscript. Benjamin Wilson was supported by a Florida International University Teaching Assistantship, Florida Sea Grant, FCE LTER and FIU Dissertation Year Fellowship. This is contribution xxxx of the Southeast Environmental Research Center.

\section{LITERATURE CITED}

Allan, R. P., and B. J. Soden. 2008. Atmospheric warming and the amplification of precipitation extremes. Science 321:1481-1484.

Amador, J. A., and R. D. Jones. 1993. Nutrient limitations on microbial respiration in peat soils with different total phosphorus content. Soil Biology \& Biochemistry 25:793-801.

Anderson, C. J., and B. G. Lockaby. 2012. Seasonal patterns of river connectivity and saltwater intrusion in tidal freshwater forested wetlands. River Research and Applications 28:814-826.

Ardon, M., J. L. Morse, B. P. Colman, and E. S. Bernhardt. 2013. Drought-induced saltwater incursion leads to increased wetland nitrogen export. Global Change Biology 19:2976-2985.

Atkinson, M. J., and C. Bingman. 1997. Elemental composition of commercial seasalts. Journal of Aquariculture and Aquatic Sciences 3:39-43.

Baustian, J. J., I. A. Mendelssohn, and M. W. Hester. 2012. Vegetation's importance in regulating surface elevation in a coastal salt marsh facing elevated rates of sea level rise. Global Change Biology 18:3377-3382.

Burdige, D. J. 2006. Geochemistry of marine sediments. Princeton University Press, Princeton.

Cannell, M. G. R., and J. H. M. Thornley. 2000. Modelling the components of plant respiration: Some guiding principles. Annals of Botany 85:45-54. 
Chambers, L. G., S. E. Davis, T. T. Troxler, J. N. Boyer, A. Downey-Wall, and L. J. Scinto. 2013. Biogeochemical effects of simulated sea level rise on carbon loss in an Everglades mangrove peat soil. Hydrobiologia:doi 10.1007/s10750-1001311764-10756.

Chambers, L. G., K. R. Reddy, and T. Z. Osborne. 2011. Short-Term Response of Carbon Cycling to Salinity Pulses in a Freshwater Wetland. Soil Science Society of America Journal 75:2000-2007.

Childers, D. L., D. Iwaniec, D. Rondeau, G. Rubio, E. Verdon, and C. J. Madden. 2006. Responses of sawgrass and spikerush to variation in hydrologic drivers and salinity in Southern Everglades marshes. Hydrobiologia 569:273-292.

Chmura, G. L., S. C. Anisfeld, D. R. Cahoon, and J. C. Lynch. 2003. Global carbon sequestration in tidal, saline wetland soils. Global Biogeochemical Cycles 17:12.

Comas, X., and W. Wright. 2012. Heterogeneity of biogenic gas ebullition in subtropical peat soils is revealed using time-lapse cameras. Water Resources Research 48.

Comas, X., and W. Wright. 2014. Investigating carbon flux variability in subtropical peat soils of the Everglades using hydrogeophysical methods. Journal of Geophysical Research-Biogeosciences 119:1506-1519.

Cormier, N., K. W. Krauss, and W. H. Conner. 2013. Periodicity in Stem Growth and Litterfall in Tidal Freshwater Forested Wetlands: Influence of Salinity and Drought on Nitrogen Recycling. Estuaries and Coasts 36:533-546.

Craft, C., J. Clough, J. Ehman, S. Joye, R. Park, S. Pennings, H. Guo, and M. Machmuller. 2009. Forecasting the effects of accelerated sea-level rise on tidal marsh ecosystem services. Frontiers in Ecology and the Environment 7:73-78.

Craft, C. B., E. D. Seneca, and S. W. Broome. 1993. Vertical accretion in microtidal regularly and irregularly flooded estuarine marshes. Estuarine Coastal and Shelf Science 37:371-386.

Crow, S. E., and R. K. Wieder. 2005. Sources of Co-2 emission from a northern peatland: Root respiration, exudation, and decomposition. Ecology 86:1825-1834.

Dai, A. G. 2013. Increasing drought under global warming in observations and models. Nature Climate Change 3:52-58.

Daoust, R. J., and D. L. Childers. 1998. Quantifying aboveground biomass and estimating net aboveground primary production for wetland macrophytes using a nondestructive phenometric technique. Aquatic Botany 62:115-133. 
Davis, S. M., L. H. Gunderson, W. A. Park, J. R. Richardson, and J. E. Matteson. 1994. Landscape dimension, composition, and function in a changing Everglades ecosystem. Pages 419-444 in S. M. Davis and J. C. Ogden, editors. Everglades: The Ecosystem and its Restoration. St. Lucie Press, Delray Beach.

Deegan, L. A., D. S. Johnson, R. S. Warren, B. J. Peterson, J. W. Fleeger, S. Fagherazzi, and W. M. Wollheim. 2012. Coastal eutrophication as a driver of salt marsh loss. Nature 490:388-+

Delaune, R. D., J. A. Nyman, and W. H. Patrick. 1994. Peat collapse, ponding and wetland loss in a rapidly submerging coastal marsh. Journal of Coastal Research 10:1021-1030.

Delaune, R. D., C. J. Smith, and W. H. Patrick. 1983. Methane release from gulf-coast wetlands. Tellus Series B-Chemical and Physical Meteorology 35:8-15.

Dessu, S. B., R. M. Price, T. G. Troxler, and J. S. Kominoski. 2018. Effects of sea-level rise and freshwater management on long-term water levels and water quality in the Florida Coastal Everglades. Journal of Environmental Management In Press.

Duarte, C. M., J. J. Middelburg, and N. Caraco. 2005. Major role of marine vegetation on the oceanic carbon cycle. Biogeosciences 2:1-8.

Faulkner, S. P., W. H. Patrick, and R. P. Gambrell. 1989. Field techniques for measuring wetland soil parameters. Soil Science Society of America Journal 53:883-890.

Fourqurean, J. W., J. C. Zieman, and G. V. N. Powell. 1992. Relationships between porewater nutrients and seagrasses in a subtropical carbonate environment. Marine Biology 114:57-65.

Gardner, W. S., S. P. Seitzinger, and J. M. Malczyk. 1991. The effects of sea salts on the forms of nitrogen released from estuarine and fresh-water sediments - does ionpairing affect ammonium flux. Estuaries 14:157-166.

Giblin, A. E., N. B. Weston, G. T. Banta, J. Tucker, and C. S. Hopkinson. 2010. The Effects of Salinity on Nitrogen Losses from an Oligohaline Estuarine Sediment. Estuaries and Coasts 33:1054-1068.

Gobler, C. J., D. A. Hutchins, N. S. Fisher, E. M. Cosper, and S. A. Sanudo-Wilhelmy. 1997. Release and bioavailability of C, N, P, Se, and Fe following viral lysis of a marine chrysophyte. Limnology and Oceanography 42:1492-1504.

Goodrich, J. P. G. J. P., R. K. Varner, S. Frolking, B. N. Duncan, and P. M. Crill. 2011. High-frequency measurements of methane ebullition over a growing season at a 
temperate peatland site. Geophysical Research Letters

38:DOI: 10.1029/2011GL046915.

Hao, Y. B., X. Y. Cui, Y. F. Wang, X. R. Mei, X. M. Kang, N. Wu, P. Luo, and D. Zhu. 2011. Predominance of Precipitation and Temperature Controls on Ecosystem CO2 Exchange in Zoige Alpine Wetlands of Southwest China. Wetlands 31:413422.

Harvey, J. W., and P. V. McCormick. 2009. Groundwater's significance to changing hydrology, water chemistry, and biological communities of a floodplain ecosystem, Everglades, South Florida, USA. Hydrogeology Journal 17:185-201.

Herbert, E. R., P. Boon, A. J. Burgin, S. C. Neubauer, R. B. Franklin, M. Ardon, K. N. Hopfensperger, L. P. M. Lamers, and P. Gell. 2015. A global perspective on wetland salinization: ecological consequences of a growing threat to freshwater wetlands. Ecosphere 6.

Hohner, S. M., and T. W. Dreschel. 2015. Everglades peats: using historical and recent data to estimate predrainage and current volumes, masses and carbon contents. Mires and Peat 16.

Jerath, M., M. Bhat, V. H. Rivera-Monroy, E. Castaneda-Moya, M. Simard, and R. R. Twilley. 2016. The role of economic, policy, and ecological factors in estimating the value of carbon stocks in Everglades mangrove forests, South Florida, USA. Environmental Science \& Policy 66:160-169.

Jimenez, K. L., G. Starr, C. L. Staudhammer, J. L. Schedlbauer, H. W. Loescher, S. L. Malone, and S. F. Oberbauer. 2012. Carbon dioxide exchange rates from shortand long-hydroperiod Everglades freshwater marsh. Journal of Geophysical Research-Biogeosciences 117.

Lamers, L. P. M., L. L. Govers, I. Janssen, J. J. M. Geurts, M. E. W. Van der Welle, M. M. Van Katwijk, T. Van der Heide, J. G. M. Roelofs, and A. J. P. Smolders. 2013. Sulfide as a soil phytotoxin-a review. Frontiers in Plant Science 4.

Lamers, L. P. M., H. B. M. Tomassen, and J. G. M. Roelofs. 1998. Sulfate-induced entrophication and phytotoxicity in freshwater wetlands. Environmental Science \& Technology 32:199-205.

Li, L. F., W. H. Li, and Y. Kushnir. 2012. Variation of the North Atlantic subtropical high western ridge and its implication to Southeastern US summer precipitation. Climate Dynamics 39:1401-1412. 
Light, S. S., and J. W. Dineen. 1994. Water control in the Everglades: A historical perspective. Pages 47-84 in S. M. Davis and J. C. Ogden, editors. Everglades: The Ecosystem and its Restoration. St. Lucie Press, Delray Beach.

Macek, P., and E. Rejmankova. 2007. Response of emergent macrophytes to experimental nutrient and salinity additions. Functional Ecology 21:478-488.

Malone, S. L., G. Starr, C. L. Staudhammer, and M. G. Ryan. 2013. Effects of simulated drought on the carbon balance of Everglades short-hydroperiod marsh.

Malone, S. L., C. L. Staudhammer, S. F. Oberbauer, P. Olivas, M. G. Ryan, J. L. Schedlbauer, H. W. Loescher, and G. Starr. 2014. El Nino Southern Oscillation (ENSO) Enhances CO2 Exchange Rates in Freshwater Marsh Ecosystems in the Florida Everglades. Plos One 9.

McKee, K. L. 2011. Biophysical controls on accretion and elevation change in Caribbean mangrove ecosystems. Estuarine Coastal and Shelf Science 91:475-483.

McKee, K. L., I. A. Mendelssohn, and M. W. Hester. 1988. Reexamination of pore water sulfide concentrations and redox potentials near the aerial roots of Rhizophora mangle and Avicennia germinans. American Journal of Botany 75:1352-1359.

McLeod, E., G. L. Chmura, S. Bouillon, R. Salm, M. Bjork, C. M. Duarte, C. E. Lovelock, W. H. Schlesinger, and B. R. Silliman. 2011. A blueprint for blue carbon: toward an improved understanding of the role of vegetated coastal habitats in sequestering CO2. Frontiers in Ecology and the Environment 9:552560 .

McVoy, C. W., W. P. Said, J. Obeysekera, J. Van Arman, and T. W. Dreschel. 2011. Landscapes and Hydrology of the Predrainage Everglades. University of Florida Press, Gainesville, FL.

Megonigal, J. P., and W. H. Schlesinger. 2002. Methane-limited methanotrophy in tidal freshwater swamps. Global Biogeochemical Cycles 16.

Miller, W. D., S. C. Neubauer, and I. C. Anderson. 2001. Effects of sea level induced disturbances on high salt marsh metabolism. Estuaries 24:357-367.

Mitsch, W. J., and J. G. Gosselink. 2007. Wetlands. 4th ed. edition. John Wiley \& Sons, Inc., Hoboken, NJ.

Munns, R., and M. Tester. 2008. Mechanisms of salinity tolerance. Annual Review of Plant Biology 59:651-681. 
National Academies of Sciences, E., and Medicine. 2016. Progress Toward Restoring the Everglades: The Sixth Biennial Review - 2016. The National Academies Press, Washington D.C.

Neubauer, S. C. 2013. Ecosystem responses of a tidal freshwater marsh experiencing saltwater intrusion and altered hydrology. Estuaries and Coasts 36:491-507.

Neubauer, S. C., W. D. Miller, and I. C. Anderson. 2000. Carbon cycling in a tidal freshwater marsh ecosystem: a carbon gas flux study. Marine Ecology-Progress Series 199:13-30.

Nyman, J. A., R. D. Delaune, and W. H. Patrick. 1990. Wetland soil formation in the rapidly subsiding Mississippi River Deltaic Plain - mineral and organic-matter relationships. Estuarine Coastal and Shelf Science 31:57-69.

Nyman, J. A., R. J. Walters, R. D. Delaune, and W. H. Patrick, Jr. 2006. Marsh vertical accretion via vegetative growth. Estuarine Coastal and Shelf Science 69:370-380.

Obeysekera, J., J. Barnes, and M. Nungesser. 2015. Climate Sensitivity Runs and Regional Hydrologic Modeling for Predicting the Response of the Greater Florida Everglades Ecosystem to Climate Change. Environmental Management 55:749762.

Poffenbarger, H. J., B. A. Needelman, and J. P. Megonigal. 2011. Salinity influence on methane emissions from tidal marshes. Wetlands 31:831-842.

Price, R. M., P. K. Swart, and J. W. Fourqurean. 2006. Coastal groundwater discharge an additional source of phosphorus for the oligotrophic wetlands of the Everglades. Hydrobiologia 569:23-36.

Reddy, K. R., and R. D. DeLaune. 2008. Biogeochemistry of wetlands: science and applications. CRC Press, Boca Raton.

Ross, M. S., D. L. Reed, J. P. Sah, P. L. Ruiz, and M. T. Lewin. 2003. Vegetation: environment relationships and water management in Shark Slough, Everglades National Park. Wetlands Ecology and Management 11:291-303.

Saha, A. K., S. Saha, J. Sadle, J. Jiang, M. S. Ross, R. M. Price, L. Sternberg, and K. S. Wendelberger. 2011. Sea level rise and South Florida coastal forests. Climatic Change 107:81-108.

Schaffranek, R. W. 2004. Sheet-flow Velocities and Factors Affecting Sheet-flow Behavior of Importance to Restoration of the Florida Everglades. U.S. Geological Survey. 
Schedlbauer, J. L., J. W. Munyon, S. F. Oberbauer, E. E. Gaiser, and G. Starr. 2012. Controls on Ecosystem Carbon Dioxide Exchange in Short- and LongHydroperiod Florida Everglades Freshwater Marshes. Wetlands 32:801-812.

Schedlbauer, J. L., S. F. Oberbauer, G. Starr, and K. L. Jimenez. 2010. Seasonal differences in the $\mathrm{CO}(2)$ exchange of a short-hydroperiod Florida Everglades marsh. Agricultural and Forest Meteorology 150:994-1006.

Seitzinger, S. P., W. S. Gardner, and A. K. Spratt. 1991. The effect of salinity on ammonium sorption in aquatic sediments - Implications for benthic nutrient recycling. Estuaries 14:167-174.

Sheffield, J., E. F. Wood, and M. L. Roderick. 2012. Little change in global drought over the past 60 years. Nature 491:435-+.

Sklar, F., L. Brandt, D. DeAngelis, C. Fitz, D. Gawlik, S. Krupa, C. Madden, F. Mazzotti, C. McVoy, S. Miao, D. Rudnick, K. Rutchney, K. Tarboton, L. Vilchek, and Y. Wu. 2000. Hydrological needs - effects of hydrology on the Everglades. Pages 262. SFWMD. Everglades Consolidated Report, South Florida Water Management District, West Palm Beach, FL, USA.

Sklar, F. H., M. J. Chimney, S. Newman, P. McCormick, D. Gawlik, S. L. Miao, C. McVoy, W. Said, J. Newman, C. Coronado, G. Crozier, M. Korvela, and K. Rutchey. 2005. The ecological-societal underpinnings of Everglades restoration. Frontiers in Ecology and the Environment 3:161-169.

Solorzano, L., and J. H. Sharp. 1980. Determination of total dissolved phosphorus and particulate phosphorus in natural-waters. Limnology and Oceanography 25:754757.

Spalding, E. A., and M. W. Hester. 2007. Interactive effects of hydrology and salinity on oligohaline plant species productivity: Implications of relative sea-level rise. Estuaries and Coasts 30:214-225.

Trenberth, K. E., A. G. Dai, G. van der Schrier, P. D. Jones, J. Barichivich, K. R. Briffa, and J. Sheffield. 2014. Global warming and changes in drought. Nature Climate Change 4:17-22.

Troxler, T. G., D. L. Childers, and C. J. Madden. 2014. Drivers of Decadal-Scale Change in Southern Everglades Wetland Macrophyte Communities of the Coastal Ecotone. Wetlands 34:S81-S90.

Wanless, H. R., and B. M. Vlaswinkel. 2005. Coastal landscape and channel evolution affecting critical habitats at Cape Sable, Everglades National Park, Florida. 
Webster, K. L., J. W. McLaughlin, Y. Kim, M. S. Packalen, and C. S. Li. 2013. Modelling carbon dynamics and response to environmental change along a boreal fen nutrient gradient. Ecological Modelling 248:148-164.

Weston, N. B., R. E. Dixon, and S. B. Joye. 2006. Ramifications of increased salinity in tidal freshwater sediments: Geochemistry and microbial pathways of organic matter mineralization. Journal of Geophysical Research-Biogeosciences 111:doi: 10.1029/2005JG000071.

Weston, N. B., A. E. Giblin, G. T. Banta, C. S. Hopkinson, and J. Tucker. 2010. The Effects of Varying Salinity on Ammonium Exchange in Estuarine Sediments of the Parker River, Massachusetts. Estuaries and Coasts 33:985-1003.

Weston, N. B., S. C. Neubauer, D. J. Velinsky, and M. A. Vile. 2014. Net ecosystem carbon exchange and the greenhouse gas balance of tidal marshes along an estuarine salinity gradient. Biogeochemistry 120:163-189.

Weston, N. B., M. A. Vile, S. C. Neubauer, and D. J. Velinsky. 2011. Accelerated microbial organic matter mineralization following salt-water intrusion into tidal freshwater marsh soils. Biogeochemistry 102:135-151.

Whiting, G. J., D. S. Bartlett, S. M. Fan, P. S. Bakwin, and S. C. Wofsy. 1992. Biosphere atmosphere $\mathrm{CO} 2$ exchange in tundra ecosystems - community characteristics and relationships with multispectral surface reflectance. Journal of Geophysical Research-Atmospheres 97:16671-16680.

Whittle, A., and A. V. Gallego-Sala. 2016. Vulnerability of the peatland carbon sink to sea-level rise. Scientific Reports 6.

Wilson, B. J., B. Mortazavi, and R. P. Kiene. 2015. Spatial and temporal variability in carbon dioxide and methane exchange at three coastal marshes along a salinity gradient in a northern Gulf of Mexico estuary. Biogeochemistry 123:329-347.

Wright, A. L., and K. R. Reddy. 2001. Heterotrophic microbial activity in northern Everglades wetland soils. Soil Science Society of America Journal 65:1856-1864.

Zhang, K., J. Dittmar, M. Ross, and C. Bergh. 2011. Assessment of sea level rise impacts on human population and real property in the Florida Keys. Climatic Change 107:129-146.

Zimmermann, C. F., and C. W. Keefe. 1997. Method 440.0. Determination of carbon and nitrogen in sediments and particulates of estuarine/coastal waters using elemental analysis. U.S. Environmental Protection Agency, National Exposure Research Laboratory, Office of Research and Development, Cincinnati, Ohio. 


\section{FIGURES}

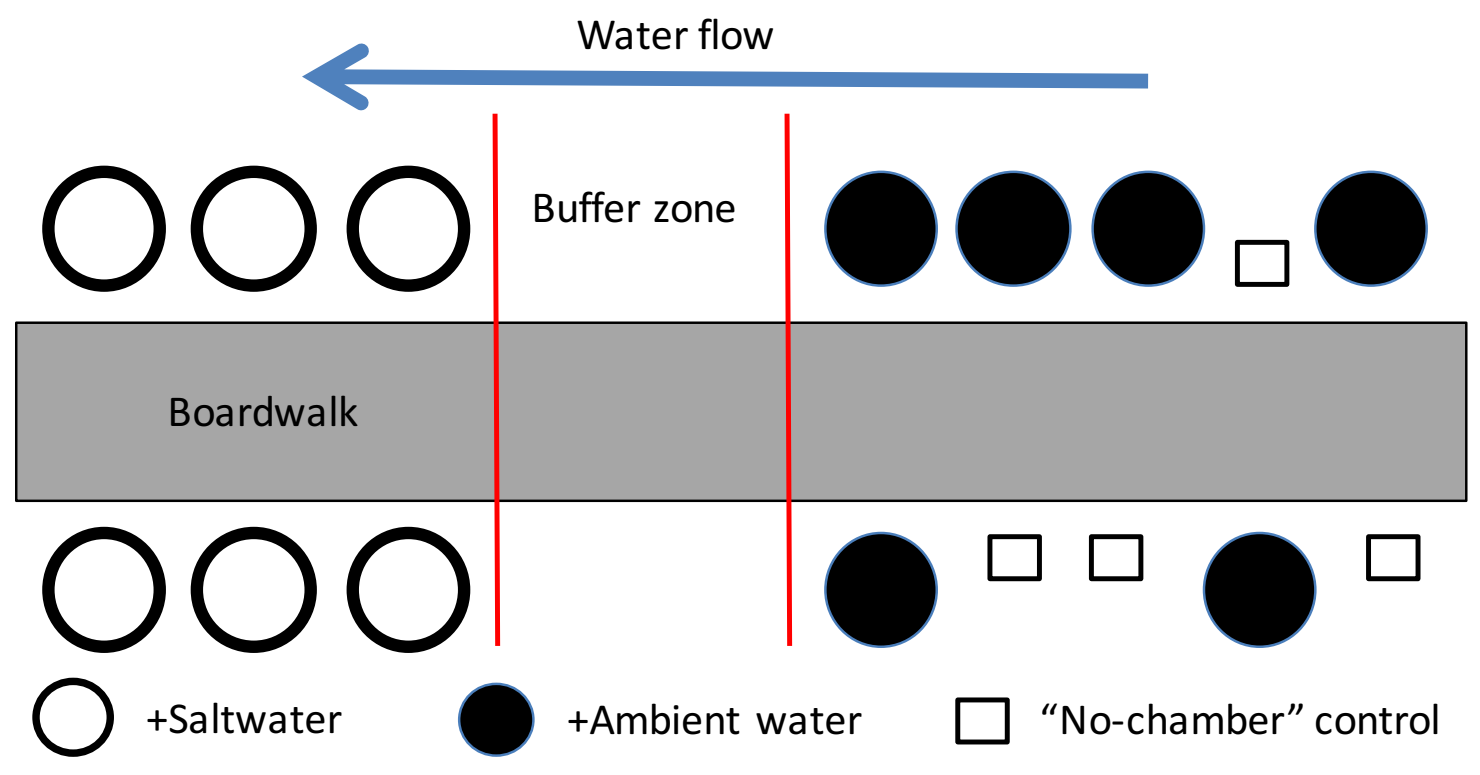

Figure 1. Experimental setup at the FW site (not to scale). The setup was similar at the BW site. Sixteen plots were established along a boardwalk, with a 3-m buffer zone between the saltwater-amended plots and the ambient water-amended plots. "Nochamber" controls received no water additions. The +SALT plots were positioned downstream of flow to minimize contamination of the control plots. 


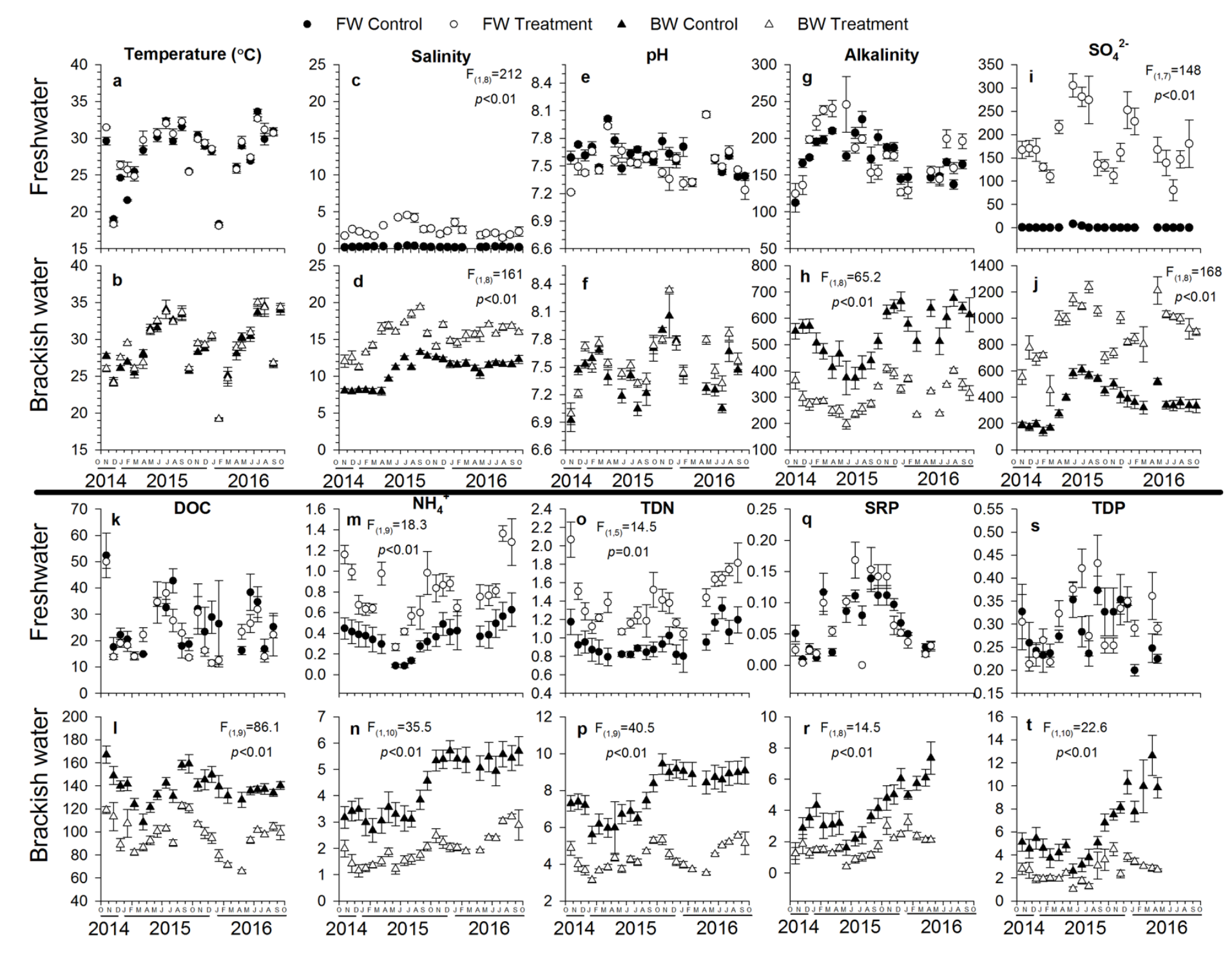


Figure 2. Mean $(n=6) \pm 1 \mathrm{SE}$ of monthly porewater temperature, salinity, $\mathrm{pH}$, alkalinity, sulfate $\left(\mathrm{SO}_{4}{ }^{2-}\right)$, dissolved organic carbon (DOC), ammonium $\left(\mathrm{NH}_{4}^{+}\right.$), total dissolved nitrogen (TDN), soluble reactive phosphorus (SRP), and total dissolved phosphorus (TDP) from the freshwater (FW) and brackish water (BW) sites over the two-year duration of the study taken at 15-cm depth from

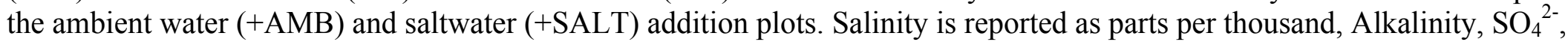
DOC, $\mathrm{NH}_{4}{ }^{+}$, and TDN are reported in $\mathrm{mg} \mathrm{L}^{-1}$, and SRP and TDP are reported in $\mu \mathrm{g} \mathrm{L}^{-1}$. 


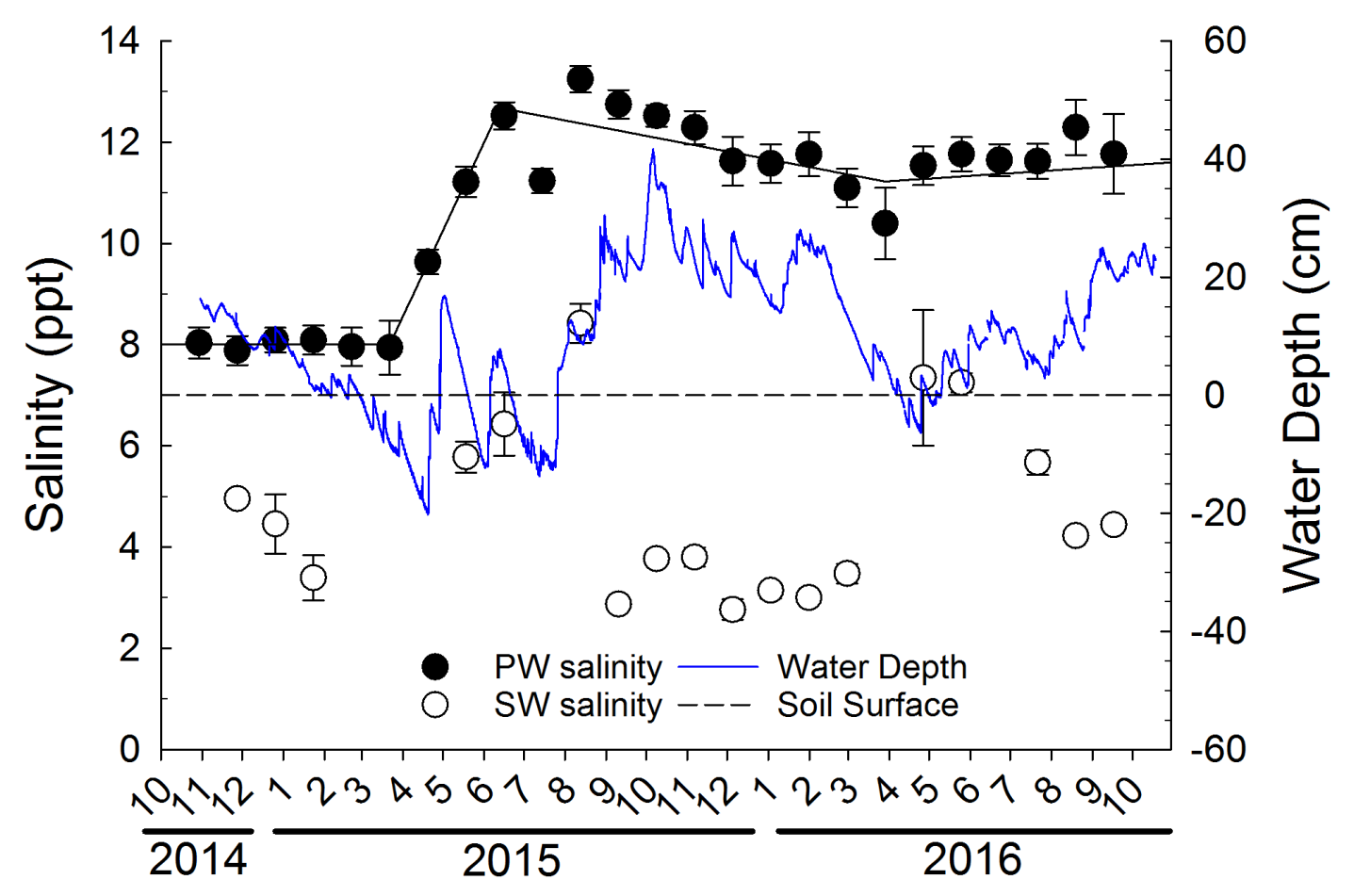

Figure 3 . Mean $(n=6) \pm 1$ SE of monthly porewater $(\mathrm{PW})$ and surface water (SW) salinity and daily water depth from the brackish water site within the +ambient-water plots. Soil surface is plotted as the $0-\mathrm{cm}$ water mark (dashed line) to show its relation to water depth. Solid lines show the results of a piecewise regression with relevant change-points for PW salinity 


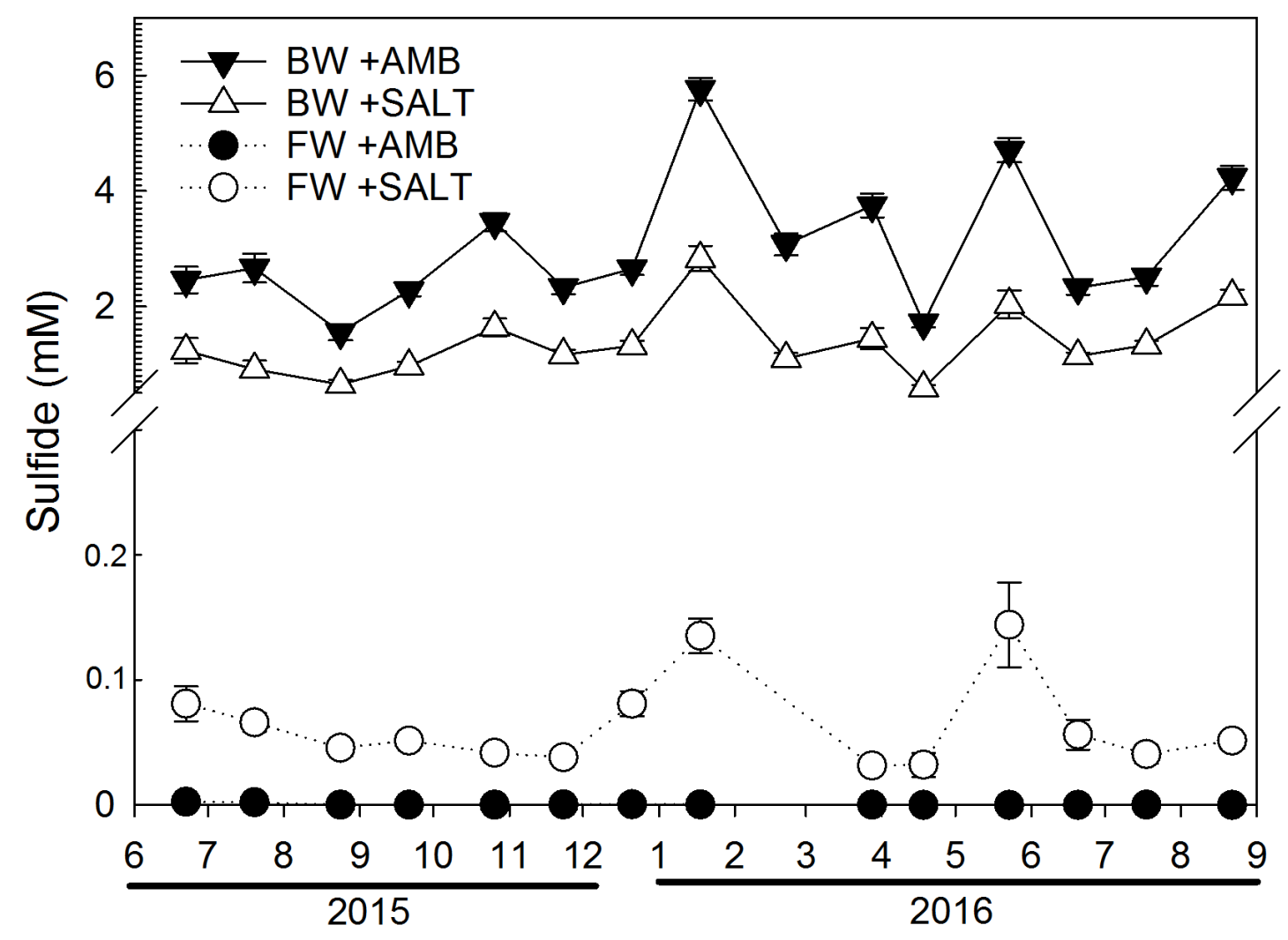

Figure 3. Mean $(n=6) \pm 1 \mathrm{SE}$ of monthly porewater sulfide at 15 -cm depth at the freshwater (FW) and brackish water (BW) sites from the ambient-water amended $(+\mathrm{AMB})$ and saltwater amended (+SALT) plots. 

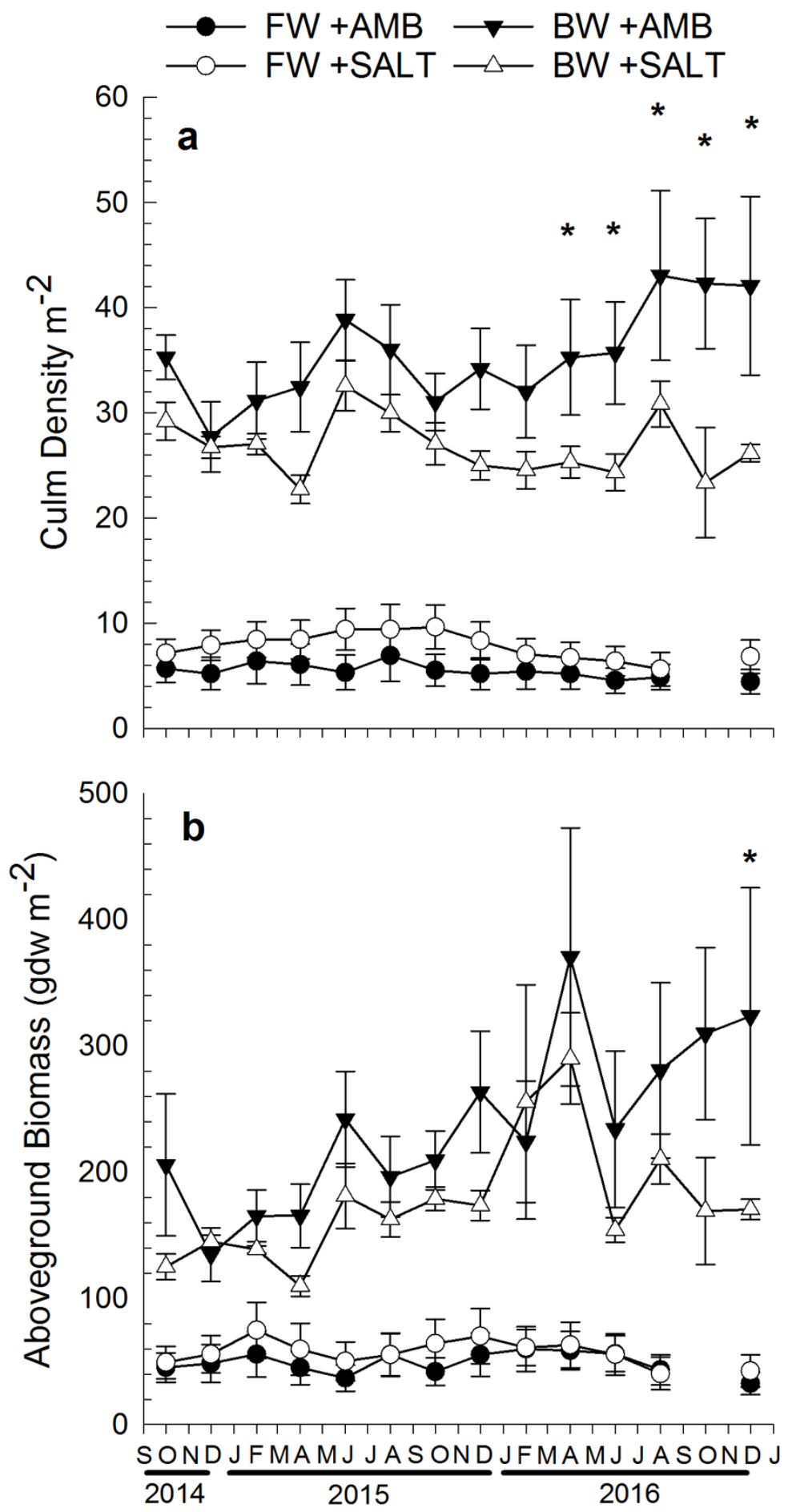

Figure 4. Change in Cladium jamaicense (sawgrass) culm density and aboveground live biomass over time at the freshwater (FW) and brackish water (BW) sites for the ambient amended $(+$ AMB $)$ and saltwater amended $(+$ SALT) treatments. Points represent the monthly mean $(n=6) \pm 1 \mathrm{SE}$. Stars above the data point indicate that there was a significant (LSMEANS, $P<0.10$ ) difference among treatments for that site. 


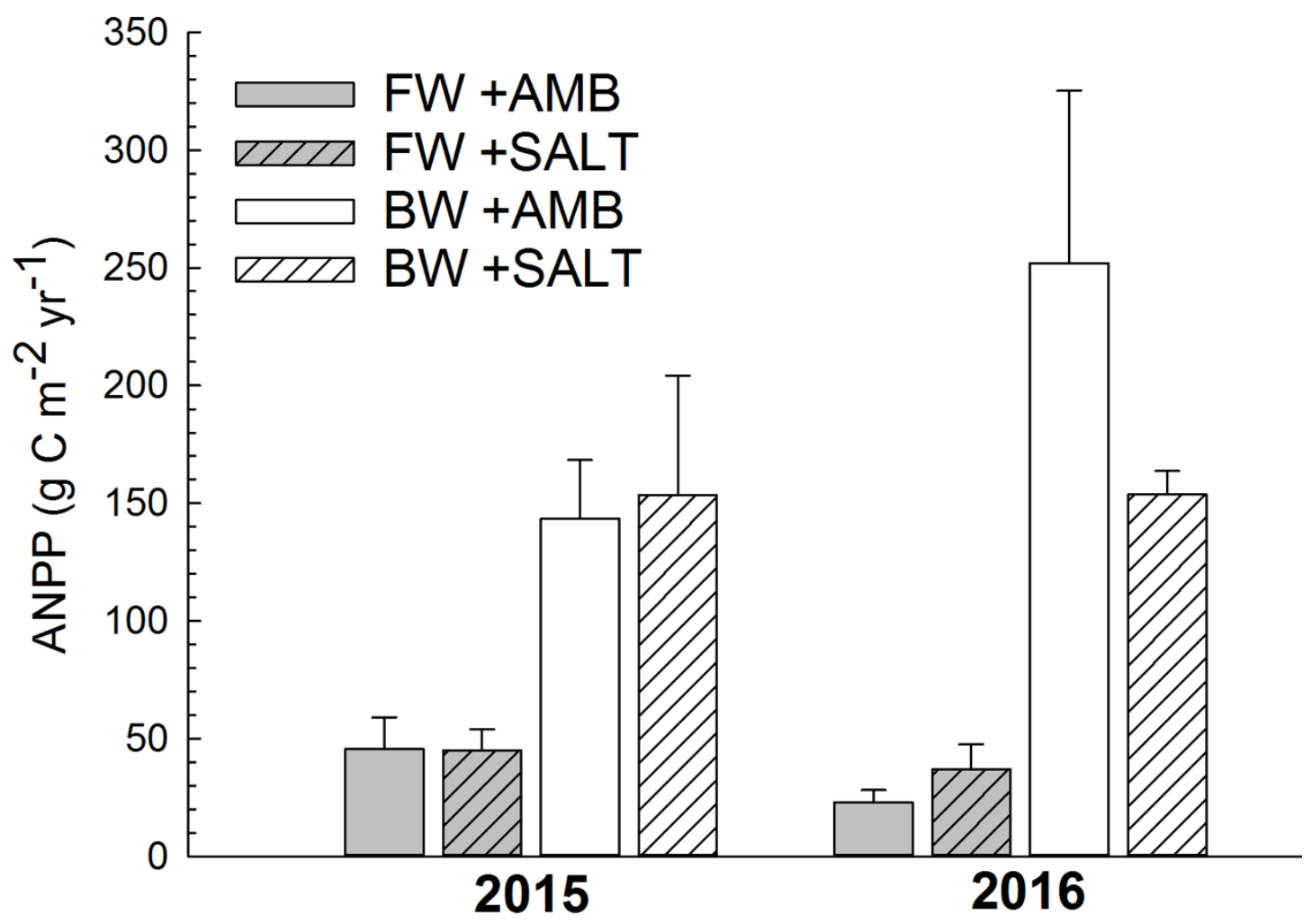

Figure 5. Annual mean $(n=6) \pm 1 \mathrm{SE}$ of sawgrass aboveground net primary productivity (ANPP) separated by freshwater (FW) and brackish water (BW) site, ambient-water amended (+AMB) and saltwater-amended (+SALT) treatments, and year. 


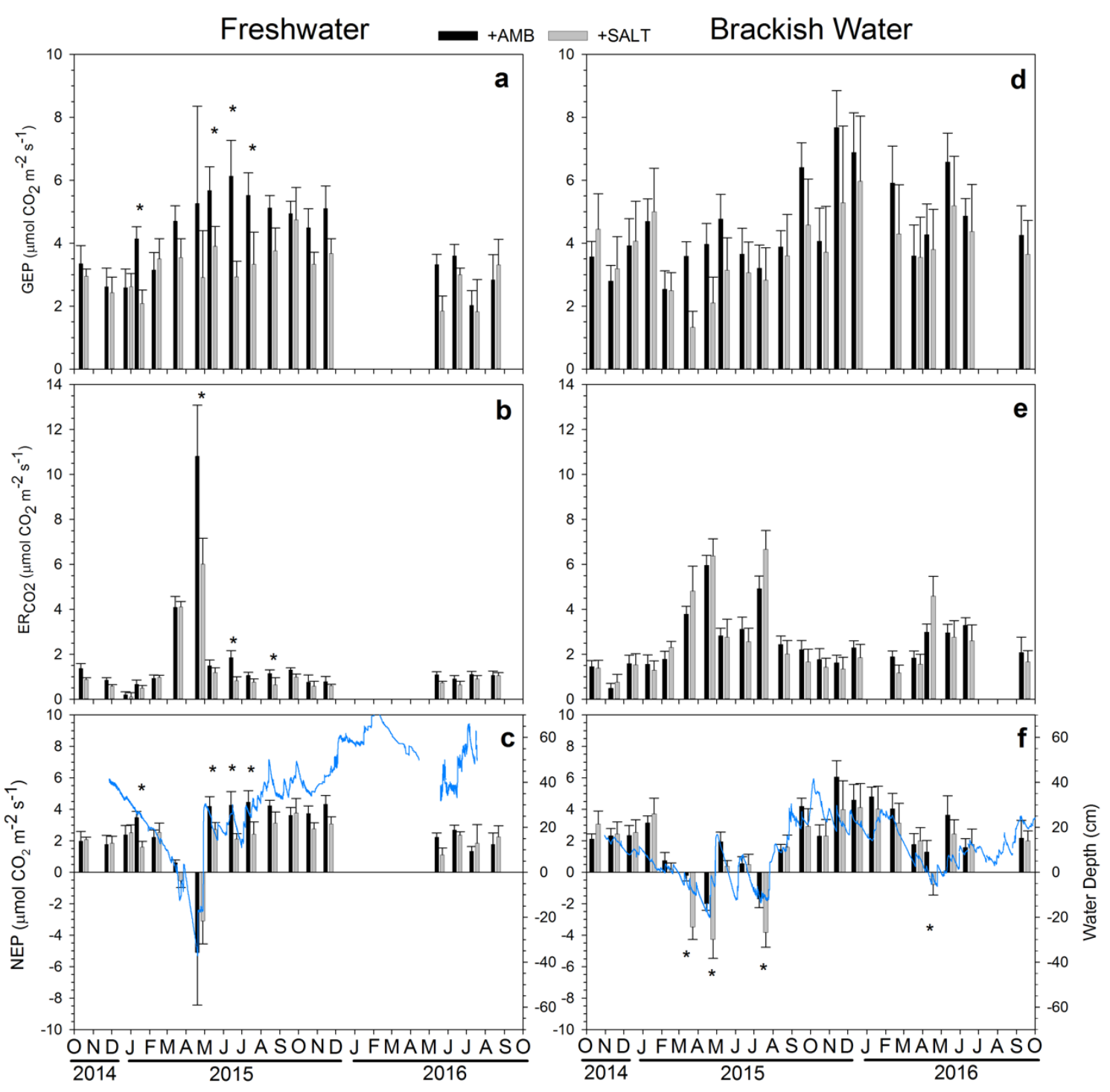

Figure 6. Instantaneous rates (mean, $n=4 \pm 1 \mathrm{SE}$ ) of freshwater gross ecosystem productivity ( $\mathrm{a}$; GEP), ecosystem respiration of $\mathrm{CO}_{2}(\mathrm{~b}$; ER), and net ecosystem productivity (c; NEP) and brackish water GEP (d), ER $\mathrm{CO}_{2}(\mathrm{e})$, and NEP (f) over 2 years from both the freshwater and brackish sites. The bottom panel also plots water level (blue line) in relation to the soil surface over time. For figure clarity, the "no-chamber" control plots were not added, as they were not significantly different from the + AMB plots $(P>0.10)$. Stars represent months in which treatments were significantly different from each other (LSMEANS, $P<0.10$ ). 


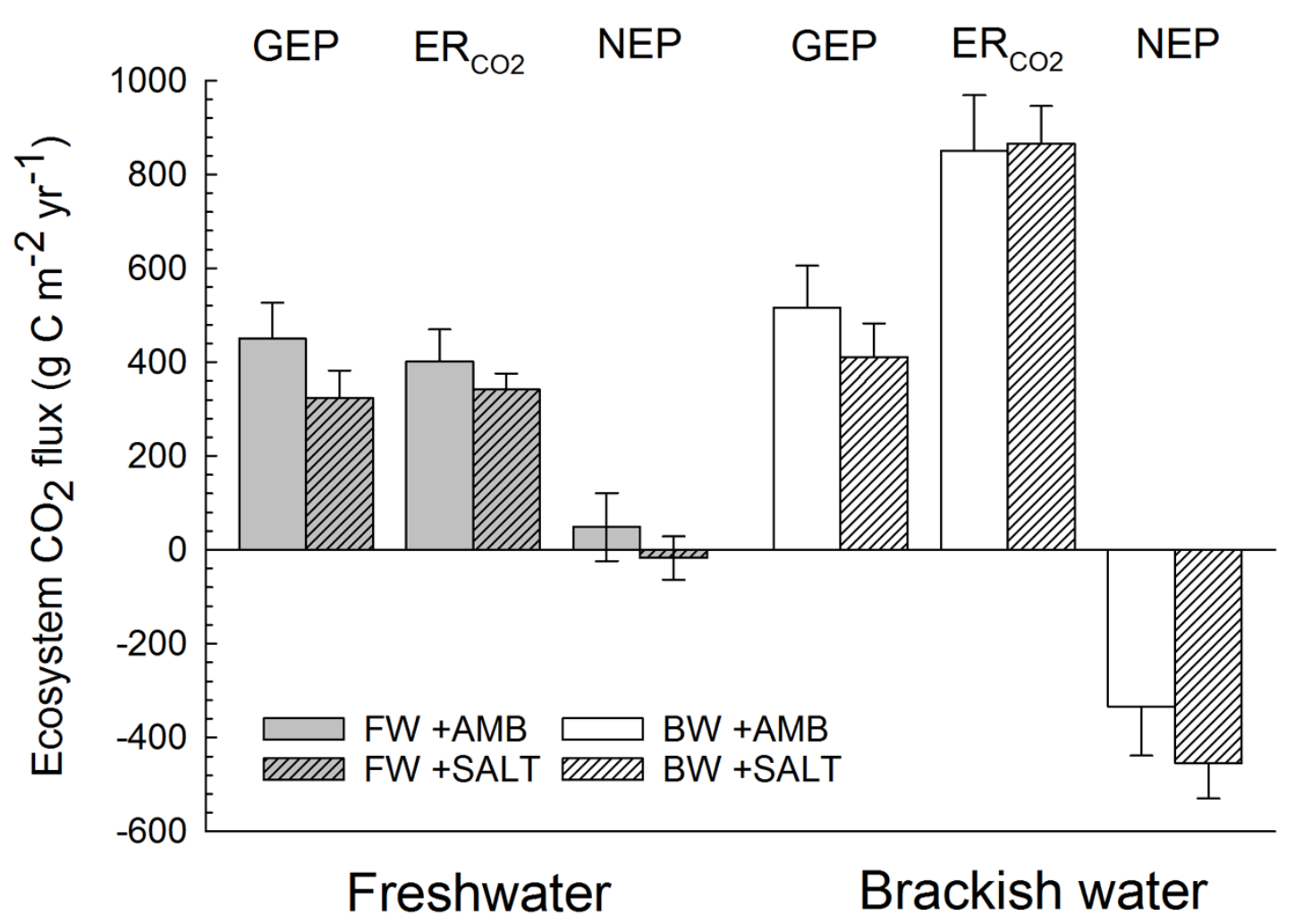

Figure 7. Estimated ecosystem $\mathrm{C}$ cycling over the two-year study period for net ecosystem productivity (NEP), gross ecosystem productivity (GEP), and ecosystem respiration of $\mathrm{CO}_{2}\left(\mathrm{ER}_{\mathrm{CO} 2}\right)$ from the freshwater $(\mathrm{FW})$ and brackish water $(\mathrm{BW})$ sites and how it changes ambient water (+AMB) or saltwater (+SALT) pulses. A negative NEP indicates that the marsh is a net $\mathrm{C}$ source to the atmosphere. Values represent mean $(n=6)$ $\pm 1 \mathrm{SD}$ flux over the experimental timeframe in $\mathrm{g} \mathrm{C} \mathrm{m}^{-2} \mathrm{y}^{-1}$. Annual flux was calculated using previously published GEP, PAR, ER, and temperature relationships for sawgrass (see Supplemental Methods) and previously derived light response curves for a sawgrass freshwater and brackish marsh (Neubauer 2013, Wilson et al. 2015). 


\section{TABLES}

Table 1 . Soil physicochemical properties (mean $\pm \mathrm{SE}, n=6$ ) by site and by depth.

\begin{tabular}{|c|c|c|c|c|c|c|c|}
\hline Site & $\begin{array}{l}\text { Depth } \\
\text { (cm) }\end{array}$ & Treatment & $\begin{array}{l}\text { Bulk } \\
\text { Density (g } \\
\text { cm }^{-3} \text { ) }\end{array}$ & $\begin{array}{l}\text { Organic } \\
\text { matter }(\%)\end{array}$ & $\begin{array}{l}\text { Total C } \\
(\%)\end{array}$ & $\begin{array}{l}\text { Total N } \\
(\%)\end{array}$ & Total P (\%) \\
\hline \multirow[t]{6}{*}{ Freshwater } & $0-10$ & $+\mathrm{AMB}$ & $0.08 \pm 0.03$ & $83.2 \pm 4.6$ & $40.6 \pm 2.7$ & $3.29 \pm 0.18$ & $0.052 \pm 0.007$ \\
\hline & & + SALT & $0.11 \pm 0.02$ & $71.3 \pm 4.4$ & $35.2 \pm 2.9$ & $3.29 \pm 0.18$ & $0.057 \pm 0.006$ \\
\hline & $10-20$ & $+\mathrm{AMB}$ & $0.18 \pm 0.06$ & $70.2 \pm 9.5$ & $34.6 \pm 5.5$ & $2.80 \pm 0.27$ & $0.039 \pm 0.008$ \\
\hline & & + SALT & $0.18 \pm 0.04$ & $67.9 \pm 7.9$ & $31.0 \pm 4.4$ & $3.00 \pm 0.23$ & $0.052 \pm 0.008$ \\
\hline & $20-30$ & $+\mathrm{AMB}$ & $0.17 \pm 0.03$ & $63.2 \pm 11.7$ & $31.1 \pm 5.5$ & $2.51 \pm 0.34$ & $0.040 \pm 0.010$ \\
\hline & & + SALT & $0.22 \pm 0.04$ & $55.7 \pm 9.4$ & $25.9 \pm 6.1$ & $2.55 \pm 0.50$ & $0.042 \pm 0.010$ \\
\hline \multirow{6}{*}{$\begin{array}{l}\text { Brackish } \\
\text { water }\end{array}$} & $0-10$ & $+\mathrm{AMB}$ & $0.07 \pm 0.02$ & $85.8 \pm 2.7$ & $42.7 \pm 0.9$ & $2.47 \pm 0.31$ & $0.052 \pm 0.007$ \\
\hline & & +SALT & $0.07 \pm 0.02$ & $84.6 \pm 2.8$ & $43.1 \pm 1.0$ & $2.17 \pm 0.25$ & $0.044 \pm 0.011$ \\
\hline & $10-20$ & $+\mathrm{AMB}$ & $0.11 \pm 0.02$ & $84.5 \pm 2.2$ & $43.1 \pm 1.1$ & $2.35 \pm 0.24$ & $0.039 \pm 0.008$ \\
\hline & & + SALT & $0.11 \pm 0.02$ & $84.6 \pm 2.5$ & $42.9 \pm 2.1$ & $1.92 \pm 0.28$ & $0.033 \pm 0.004$ \\
\hline & $20-30$ & $+\mathrm{AMB}$ & $0.11 \pm 0.04$ & $83.2 \pm 1.7$ & $42.6 \pm 0.8$ & $2.10 \pm 0.22$ & $0.031 \pm 0.005$ \\
\hline & & + SALT & $0.12 \pm 0.05$ & $83.0 \pm 3.5$ & $42.1 \pm 1.6$ & $1.99 \pm 0.21$ & $0.029 \pm 0.005$ \\
\hline
\end{tabular}


Table 2. Full statistical results from a linear mixed model for porewater constituents from the freshwater (FW) and brackish water (BW) sites given treatment (trt) and date. Interpreted results in bold. Data presented as $F$ (numerator degrees of freedom,denominator degrees of freedom) $=F$ value, $P=P$ value. The arrows indicate, if significant, in what direction elevated salinity altered the given parameter.

$D O C$ dissolved organic carbon, $\mathrm{NH}_{4}^{+}$ammonium, $\mathrm{TDN}$ total dissolved nitrogen, $\mathrm{SO}_{4}{ }^{2-}$ sulfate, $T D P$ total dissolved phosphorus, $S R P$ soluble reactive phosphorus

\begin{tabular}{|c|c|c|c|c|c|c|c|}
\hline Site & & Temperature & Salinity & pH & Alkalinity & $\mathrm{SO}_{4}{ }^{2-}$ & DOC \\
\hline \multirow[t]{3}{*}{ FW } & Trt & $\begin{array}{l}F(1,10)=2.58 \\
P=0.112\end{array}$ & $\begin{array}{l}F(1,10)=1048 \\
P<0.001\end{array}$ & $\begin{array}{l}F(1,10)=22.79 \\
P<0.001\end{array}$ & $\begin{array}{l}F(1,10)=2.65 \\
P=0.105\end{array}$ & $\begin{array}{l}F(1,10)=910 \\
P<0.001\end{array}$ & $\begin{array}{l}F(1,10)=5.72 \\
P=0.017\end{array}$ \\
\hline & Date & $\begin{array}{l}F(21,199)=125.5 \\
P<0.001\end{array}$ & $\begin{array}{l}F(21,213)=7.46 \\
P<0.001\end{array}$ & $\begin{array}{l}F(19,189)=21.9 \\
P<0.001\end{array}$ & $\begin{array}{l}F(19,189)=16.3 \\
P<0.001\end{array}$ & $\begin{array}{l}F(19,190)=5.96 \\
P<0.001\end{array}$ & $\begin{array}{l}F(19,188)=4.77 \\
P<0.001\end{array}$ \\
\hline & $\begin{array}{l}\text { Trt* } \\
\text { Date }\end{array}$ & $\begin{array}{l}F(21,199)=2.58 \\
P<0.001\end{array}$ & $\begin{array}{l}F(21,213)=6.32 \\
P<0.001\end{array}$ & $\begin{array}{l}F(19,189)=2.16 \\
P=0.004\end{array}$ & $\begin{array}{l}F(19,189)=3.76 \\
P<0.001\end{array}$ & $\begin{array}{l}F(19,190)=5.51 \\
P<0.001\end{array}$ & $\begin{array}{l}F(19,188)=1.03 \\
P=0.427\end{array}$ \\
\hline \multirow[t]{3}{*}{$\mathbf{B W}$} & Trt & $\begin{array}{l}F(1,10)=2.75 \\
P=0.098\end{array}$ & $\begin{array}{l}F(1,10)=301.8 \\
P<0.001\end{array}$ & $\begin{array}{l}F(1,10)=17.16 \\
P<0.001\end{array}$ & $\begin{array}{l}F(1,10)=142.8 \\
P<0.001\end{array}$ & $\begin{array}{l}F(1,10)=223.5 \\
P<0.001\end{array}$ & $\begin{array}{l}F(1,10)=157.9 \\
P<0.001\end{array}$ \\
\hline & Date & $\begin{array}{l}F(23,239)=81.68 \\
P<0.001\end{array}$ & $\begin{array}{l}F(23,239)=32.2 \\
P<0.001\end{array}$ & $\begin{array}{l}F(22,226)=19.6 \\
P<0.001\end{array}$ & $\begin{array}{l}F(22,227)=12.2 \\
P<0.001\end{array}$ & $\begin{array}{l}F(22,227)=21.3 \\
P<0.001\end{array}$ & $\begin{array}{l}F(22,228)=10.7 \\
P<0.001\end{array}$ \\
\hline & $\begin{array}{l}\text { Trt* } \\
\text { Date }\end{array}$ & $\begin{array}{l}F(23,239)=1.19 \\
P=0.248\end{array}$ & $\begin{array}{l}F(23,239)=7.02 \\
P<0.001\end{array}$ & $\begin{array}{l}F(22,226)=4.12 \\
P<0.001\end{array}$ & $\begin{array}{l}F(22,227)=1.88 \\
P=0.011\end{array}$ & $\begin{array}{l}F(22,227)=4.15 \\
P<0.001\end{array}$ & $\begin{array}{l}F(22,228)=1.86 \\
P=0.012\end{array}$ \\
\hline \multirow{4}{*}{$\begin{array}{l}\text { Site } \\
\text { FW }\end{array}$} & & $\mathrm{NH}_{4}^{+}$ & TDN & SRP & TDP & Sulfide & Redox \\
\hline & Trt & $\begin{array}{l}F(1,10)=176.2 \\
P<0.001\end{array}$ & $\begin{array}{l}F(1,10)=178.2 \\
P<0.001\end{array}$ & $\begin{array}{l}F(1,10)=0.09 \\
P=0.761\end{array}$ & $\begin{array}{l}F(1,10)=1.50 \\
P=0.221\end{array}$ & $\begin{array}{l}F(1,10)=302.3 \\
P<0.001\end{array}$ & $\begin{array}{l}F(1,10)=21.80 \\
P<0.001\end{array}$ \\
\hline & Date & $\begin{array}{l}F(19,189)=6.99 \\
P<0.001\end{array}$ & $\begin{array}{l}F(19,189)=7.23 \\
P<0.001\end{array}$ & $\begin{array}{l}F(20,206)=21.54 \\
P<0.001\end{array}$ & $\begin{array}{l}F(20,206)=9.59 \\
P<0.001\end{array}$ & $\begin{array}{l}F(11,117)=16.65 \\
P<0.001\end{array}$ & $\begin{array}{l}F(1,222)=244.0 \\
P<0.001\end{array}$ \\
\hline & $\begin{array}{l}\text { Trt* } \\
\text { Date }\end{array}$ & $\begin{array}{l}F(19,189)=1.43 \\
P=0.116\end{array}$ & $\begin{array}{l}F(19,189)=1.30 \\
P=0.184\end{array}$ & $\begin{array}{l}F(20,206)=2.53 \\
P<0.001\end{array}$ & $\begin{array}{l}F(20,206)=3.15 \\
P<0.001\end{array}$ & $\begin{array}{l}F(11,117)=12.81 \\
P<0.001\end{array}$ & $\begin{array}{l}F(1,222)=0.83 \\
P=0.363\end{array}$ \\
\hline \multirow[t]{3}{*}{$\mathbf{B W}$} & Trt & $\begin{array}{l}F(1,10)=229.9 \\
P<0.001\end{array}$ & $\begin{array}{l}F(1,10)=265.0 \\
P<0.001\end{array}$ & $\begin{array}{l}F(1,10)=94.83 \\
P<0.001\end{array}$ & $\begin{array}{l}F(1,10)=99.36 \\
P<0.001\end{array}$ & $\begin{array}{l}F(1,10)=217.5 \\
P<0.001\end{array}$ & $\begin{array}{l}F(1,10)=1.47 \\
P=0.252\end{array}$ \\
\hline & Date & $\begin{array}{l}F(22,228)=11.03 \\
P<0.001\end{array}$ & $\begin{array}{l}F(22,228)=7.68 \\
P<0.001\end{array}$ & $\begin{array}{l}F(23,236)=10.02 \\
P<0.001\end{array}$ & $\begin{array}{l}F(23,239)=11.43 \\
P<0.001\end{array}$ & $\begin{array}{l}F(14,149)=45.94 \\
P<0.001\end{array}$ & $\begin{array}{l}F(1,165)=87.04 \\
P<0.001\end{array}$ \\
\hline & $\begin{array}{l}\text { Trt* } \\
\text { Date }\end{array}$ & $\begin{array}{l}F(22,228)=2.28 \\
P=0.001\end{array}$ & $\begin{array}{l}F(22,228)=2.74 \\
P=0.012\end{array}$ & $\begin{array}{l}F(23,236)=2.86 \\
P<0.001\end{array}$ & $\begin{array}{l}F(23,239)=4.39 \\
P<0.001\end{array}$ & $\begin{array}{l}F(14,149)=7.16 \\
P<0.001\end{array}$ & $\begin{array}{l}F(1,165)=5.09 \\
P=0.025\end{array}$ \\
\hline
\end{tabular}


Table 3. Mean $\pm \mathrm{SE}$ of $\mathrm{C}, \mathrm{N}$, and $\mathrm{P}$ sawgrass leaf content for each year. Subscripted letters represent differences between year and treatment within a site from a one-way ANOVA.

\begin{tabular}{|c|c|c|c|c|c|c|}
\hline Site & Time & Treatment & $\mathrm{C}\left(\mathrm{mg} \mathrm{g}^{-1}\right)$ & $\mathrm{N}\left(\mathrm{mg} \mathrm{g}^{-1}\right)$ & $\mathbf{P}\left(\mu \mathrm{g} \mathrm{g}^{-1}\right)$ & $\mathrm{C}: \mathrm{N}: \mathrm{P}$ \\
\hline \multirow[t]{4}{*}{$\overline{B W}$} & $\begin{array}{l}\text { Year } \\
1\end{array}$ & $+\mathrm{AMB}$ & $457 \pm 2.3^{\mathrm{a}}$ & $9.09 \pm 0.25^{\mathrm{ab}}$ & $244 \pm 17^{\text {ac }}$ & $1872: 37: 1$ \\
\hline & & + SALT & $455 \pm 2.1^{\mathrm{a}}$ & $10.17 \pm 0.26^{b}$ & $305 \pm 10^{b}$ & $1865: 42: 1$ \\
\hline & Year & $+\mathrm{AMB}$ & $488 \pm 4.9^{b}$ & $7.34 \pm 0.38^{c}$ & $206 \pm 10^{\mathrm{a}}$ & 2000:30:1 \\
\hline & & +SALT & $480 \pm 1.6^{b}$ & $8.55 \pm 0.42^{\mathrm{ac}}$ & $264 \pm 16^{b c}$ & 1967:35:1 \\
\hline \multirow[t]{4}{*}{ FW } & Year & $+\mathrm{AMB}$ & $456 \pm 3.7^{\mathrm{a}}$ & $7.74 \pm 0.19^{\mathrm{a}}$ & $232 \pm 13^{a}$ & $1869: 32: 1$ \\
\hline & & +SALT & $451 \pm 4.1^{\mathrm{a}}$ & $7.73 \pm 0.76^{\mathrm{a}}$ & $225 \pm 35^{\mathrm{a}}$ & 1848:32:1 \\
\hline & Year & $+\mathrm{AMB}$ & NA & NA & NA & \\
\hline & & +SALT & NA & NA & NA & \\
\hline
\end{tabular}


Table 3. Full statistical results from a linear mixed model for all biomass and flux measurements. Interpreted results in bold. Data presented as $F$ (numerator degrees of freedom,denominator degrees of freedom) $=F$ value, $P=P$ value

$A N P P$ aboveground net primary productivity, $G E P$ gross ecosystem productivity, $E R_{C O 2}$ ecosystem respiration of carbon dioxide, $\mathrm{NEP}$ net ecosystem productivity, $\mathrm{CH}_{4}$ methane.

\begin{tabular}{|c|c|c|c|c|c|c|}
\hline Site & & $\begin{array}{l}\text { Aboveground } \\
\text { Biomass }\end{array}$ & Culm Density & ANPP & GEP wet & GEP dry- \\
\hline \multirow[t]{3}{*}{$\begin{array}{l}\text { Fresh } \\
\text { water }\end{array}$} & Treatment & $\begin{array}{l}F(1,10)=0.19 \\
P=0.664\end{array}$ & $\begin{array}{l}F(1,9)=0.39 \\
P=0.546\end{array}$ & $\begin{array}{l}F(1,9)=0.02 \\
P=0.867\end{array}$ & $\begin{array}{l}F(1,10)=3.66 \\
P=0.084\end{array}$ & $\begin{array}{l}F(1,9)=1.56 \\
P=0.242\end{array}$ \\
\hline & Date & $\begin{array}{l}F(13,130)=5.03 \\
P<0.001\end{array}$ & $\begin{array}{l}F(13,115)=5.08 \\
P<0.001\end{array}$ & $\begin{array}{l}F(12,106)=3.39 \\
P<0.001\end{array}$ & $\begin{array}{l}F(14,134)=5.58 \\
P<0.001\end{array}$ & $\begin{array}{l}F(1,7)=0.01 \\
P=0.899\end{array}$ \\
\hline & $\begin{array}{l}\text { Treatment* } \\
\text { Date }\end{array}$ & $\begin{array}{l}F(13,130)=0.79 \\
P=0.661\end{array}$ & $\begin{array}{l}F(13,115)=0.88 \\
P=0.570\end{array}$ & $\begin{array}{l}F(12,106)=0.90 \\
P=0.544\end{array}$ & $\begin{array}{l}F(14,134)=2.21 \\
P=0.010\end{array}$ & $\begin{array}{l}F(1,7)=0.19 \\
P=0.674\end{array}$ \\
\hline \multirow[t]{3}{*}{$\begin{array}{l}\text { Brackish } \\
\text { water }\end{array}$} & Treatment & $\begin{array}{l}F(1,10)=1.30 \\
P=0.279\end{array}$ & $\begin{array}{l}F(1,10)=3.12 \\
P=0.107\end{array}$ & $\begin{array}{l}F(1,10)=0.74 \\
P=0.407\end{array}$ & $\begin{array}{l}F(1,10)=0.19 \\
P=0.671\end{array}$ & $\begin{array}{l}F(1,10)=1.28 \\
P=0.284\end{array}$ \\
\hline & Date & $\begin{array}{l}F(14,136)=6.69 \\
P<0.001\end{array}$ & $\begin{array}{l}F(14,136)=4.63 \\
P<0.001\end{array}$ & $\begin{array}{l}F(13,124)=3.77 \\
P<0.001\end{array}$ & $\begin{array}{l}F(15,149)=5.43 \\
P<0.001\end{array}$ & $\begin{array}{l}F(4,40)=2.57 \\
P=0.052\end{array}$ \\
\hline & $\begin{array}{l}\text { Treatment* } \\
\text { Date }\end{array}$ & $\begin{array}{l}F(14,136)=1.29 \\
P=0.219\end{array}$ & $\begin{array}{l}F(14,136)=2.29 \\
P=0.007\end{array}$ & $\begin{array}{l}F(13,124)=1.39 \\
P=0.170\end{array}$ & $\begin{array}{l}F(15,149)=1.37 \\
P=0.165\end{array}$ & $\begin{array}{l}F(4,40)=1.56 \\
P=0.202\end{array}$ \\
\hline
\end{tabular}

\begin{tabular}{|c|c|c|c|c|c|c|c|}
\hline Site & & $\mathbf{E R}_{\mathrm{CO} 2}$ wet & $\mathbf{E R}_{\mathrm{CO} 2}$ dry & NEP wet & NEP dry & $\mathrm{CH}_{4}$ wet & $\mathrm{CH}_{4}$ dry \\
\hline \multirow[t]{3}{*}{$\begin{array}{l}\text { Fresh } \\
\text { water }\end{array}$} & Treatment & $\begin{array}{l}F(1,10)=3.89 \\
P=0.076\end{array}$ & $\begin{array}{l}F(1,9)=2.40 \\
P=0.155\end{array}$ & $\begin{array}{l}F(1,10)=3.42 \\
P=0.093\end{array}$ & $\begin{array}{l}F(1,9)=0.00 \\
P=0.953\end{array}$ & $\begin{array}{l}F(1,6)=3.34 \\
P=0.117\end{array}$ & $\begin{array}{l}F(1,6)=3.19 \\
P=0.124\end{array}$ \\
\hline & Date & $\begin{array}{l}F(14,134)=8.32 \\
P<0.001\end{array}$ & $\begin{array}{l}F(1,7)=14.30 \\
P=0.006\end{array}$ & $\begin{array}{l}F(14,135)=4.96 \\
P<0.001\end{array}$ & $\begin{array}{l}F(1,8)=6.73 \\
P=0.031\end{array}$ & $\begin{array}{l}F(1,44)=3.14 \\
P=0.083\end{array}$ & $\begin{array}{l}F(1,4)=3.63 \\
P=0.129\end{array}$ \\
\hline & $\begin{array}{l}\text { Treatment* } \\
\text { Date }\end{array}$ & $\begin{array}{l}F(14,134)=1.45 \\
P=0.137\end{array}$ & $\begin{array}{l}F(1,7)=5.54 \\
P=0.057\end{array}$ & $\begin{array}{l}F(14,135)=1.98 \\
P=0.023\end{array}$ & $\begin{array}{l}F(1,8)=1.08 \\
P=0.327\end{array}$ & $\begin{array}{l}F(1,44)=7.88 \\
P=0.007\end{array}$ & $\begin{array}{l}F(1,4)=3.96 \\
P=0.117\end{array}$ \\
\hline \multirow[t]{3}{*}{$\begin{array}{l}\text { Brackish } \\
\text { water }\end{array}$} & Treatment & $\begin{array}{l}F(1,10)=0.30 \\
P=0.594\end{array}$ & $\begin{array}{l}F(1,10)=2.43 \\
P=0.149\end{array}$ & $\begin{array}{l}F(1,10)=0.15 \\
P=0.699\end{array}$ & $\begin{array}{l}F(1,10)=210.89 \\
P=0.008\end{array}$ & $\begin{array}{l}F(1,6)=6.30 \\
P=0.045\end{array}$ & $\begin{array}{l}F(1,6)=5.05 \\
P=0.065\end{array}$ \\
\hline & Date & $\begin{array}{l}F(15,148)=14.47 \\
P<0.001\end{array}$ & $\begin{array}{l}F(4,40)=23.16 \\
P<0.001\end{array}$ & $\begin{array}{l}F(16,157)=8.79 \\
P<0.001\end{array}$ & $\begin{array}{l}F(4,40)=15.12 \\
P<0.001\end{array}$ & $\begin{array}{l}F(1,52)=0.52 \\
P=0.471\end{array}$ & $\begin{array}{l}F(1,14)=0.69 \\
P=0.419\end{array}$ \\
\hline & $\begin{array}{l}\text { Treatment* } \\
\text { Date }\end{array}$ & $\begin{array}{l}F(15,148)=0.57 \\
P=0.887\end{array}$ & $\begin{array}{l}F(4,40)=0.78 \\
P=0.541\end{array}$ & $\begin{array}{l}F(16,157)=1.01 \\
P=0.446\end{array}$ & $\begin{array}{l}F(4,40)=1.27 \\
P=0.297\end{array}$ & $\begin{array}{l}F(1,52)=2.85 \\
P=0.097\end{array}$ & $\begin{array}{l}F(1,14)=3.05 \\
P=0.102\end{array}$ \\
\hline
\end{tabular}


Table 4. Belowground live root biomass (mean $\pm \mathrm{SE} \mathrm{g} \mathrm{C} \mathrm{m}^{-2}$ ) after two years of control $(+$ AMB) and elevated salinity (+SALT) from each site, each treatment and from specific depths. A two-way ANOVA was run separately for each site with Treatment and Depth as factors. Total depth was compared for each site separately using an independent $t$-test. Letters indicates a significant difference $(P<0.10)$.

\begin{tabular}{lrrrr|r}
\hline & \multicolumn{5}{c|}{ Depth (cm) } \\
\hline Site & Treatment & $\mathbf{0 - 1 0}$ & $\mathbf{1 0 - 2 0}$ & $\mathbf{2 0 - 3 0}$ & Total \\
BW & + AMB & $96 \pm 35^{\mathrm{a}}$ & $50 \pm 25^{\mathrm{ab}}$ & $14 \pm 4^{\mathrm{b}}$ & $159 \pm 43^{\mathrm{a}}$ \\
& + SALT & $24 \pm 8^{\mathrm{b}}$ & $12 \pm 3^{\mathrm{b}}$ & $9 \pm 2^{\mathrm{b}}$ & $45 \pm 9^{\mathrm{b}}$ \\
\hline FW & + AMB & $87 \pm 24^{\mathrm{a}}$ & $79 \pm 12^{\mathrm{ab}}$ & $76 \pm 29^{\mathrm{ab}}$ & $242 \pm 39^{\mathrm{a}}$ \\
& + SALT & $19 \pm 6^{\mathrm{b}}$ & $45 \pm 13^{\mathrm{ab}}$ & $21 \pm 3^{\mathrm{b}}$ & $85 \pm 14^{\mathrm{b}}$
\end{tabular}


Table 5. Mean \pm SE of net ecosystem productivity (NEP), gross ecosystem productivity (GEP), ecosystem respiration of $\mathrm{CO}_{2}\left(\mathrm{ER}_{\mathrm{CO} 2}\right)$, and ecosystem respiration of $\mathrm{CH}_{4}\left(\mathrm{ER}_{\mathrm{CH} 4}\right)$ from the brackish water (BW) and freshwater (FW) sites, separated by the "no-chamber" control, addition of ambient water (+AMB), and the addition of saltwater (+SALT) plots. Fluxes were separated into wet (water covering the soil surface) and dry (no surface water) periods. A negative NEP indicates a flux from the marsh to the atmosphere.

Subscripts represent the results of a two-way repeated measures ANOVA. Values without superscripts indicates that there was no significant difference between treatments for that parameter.

\begin{tabular}{|c|c|c|c|c|c|}
\hline \multirow{3}{*}{ Flux } & \multirow[b]{3}{*}{ Treatment } & \multicolumn{4}{|c|}{$\mathrm{CO}_{2}$ and $\mathrm{CH}_{4}$ flux $\left(\mu \mathrm{mol} \mathrm{m} \mathrm{m}^{-2} \mathrm{~s}^{-1}\right)$} \\
\hline & & \multicolumn{2}{|r|}{ Wet } & \multicolumn{2}{|r|}{ Dry } \\
\hline & & FW & BW & FW & BW \\
\hline \multirow[t]{3}{*}{ NEP } & Control & $3.23 \pm 0.44^{\mathrm{a}}$ & $3.06 \pm 0.47$ & $-3.06 \pm 3.43$ & $-1.25 \pm 0.61^{\mathrm{a}}$ \\
\hline & $+\mathrm{AMB}$ & $3.05 \pm 0.28^{\mathrm{a}}$ & $2.88 \pm 0.35$ & $-2.24 \pm 2.86$ & $-0.37 \pm 0.65^{\mathrm{a}}$ \\
\hline & + SALT & $2.38 \pm 0.16^{b}$ & $2.52 \pm 0.27$ & $-1.83 \pm 1.27$ & $-2.44 \pm 0.90^{b}$ \\
\hline \multirow[t]{3}{*}{ GEP } & Control & $4.41 \pm 0.51^{\mathrm{a}}$ & $5.54 \pm 0.49$ & $5.95 \pm 1.49$ & $2.61 \pm 0.42$ \\
\hline & $+\mathrm{AMB}$ & $4.04 \pm 0.32^{\mathrm{a}}$ & $4.85 \pm 0.36$ & $4.98 \pm 0.28$ & $3.51 \pm 0.30$ \\
\hline & + SALT & $3.08 \pm 0.20^{b}$ & $4.20 \pm 0.21$ & $3.23 \pm 0.32$ & $2.51 \pm 0.41$ \\
\hline \multirow[t]{3}{*}{$\mathbf{E R}_{\mathrm{CO} 2}$} & Control & $1.18 \pm 0.09^{\mathrm{a}}$ & $2.65 \pm 0.26$ & $9.01 \pm 4.92$ & $3.87 \pm 0.57$ \\
\hline & $+\mathrm{AMB}$ & $1.04 \pm 0.09^{\mathrm{a}}$ & $2.09 \pm 0.18$ & $7.45 \pm 3.36$ & $3.89 \pm 0.73$ \\
\hline & + SALT & $0.75 \pm 0.06^{b}$ & $1.77 \pm 0.15$ & $5.05 \pm 0.95$ & $4.95 \pm 0.78$ \\
\hline \multirow[t]{3}{*}{$\mathbf{E R}_{\mathrm{CH} 4}$} & Control & $0.040 \pm 0.016$ & $0.016 \pm 0.009^{\mathrm{a}}$ & $0.003 \pm 0.007$ & $-0.016 \pm 0.009$ \\
\hline & $+\mathrm{AMB}$ & $0.044 \pm 0.013$ & $0.010 \pm 0.004^{\mathrm{a}}$ & $-0.010 \pm 0.008$ & $-0.014 \pm 0.006$ \\
\hline & + SALT & $0.024 \pm 0.010$ & $-0.002 \pm 0.006^{b}$ & $0.040 \pm 0.052$ & $0.010 \pm 0.019$ \\
\hline
\end{tabular}




\section{SUPPLEMENTAL INFORMATION}

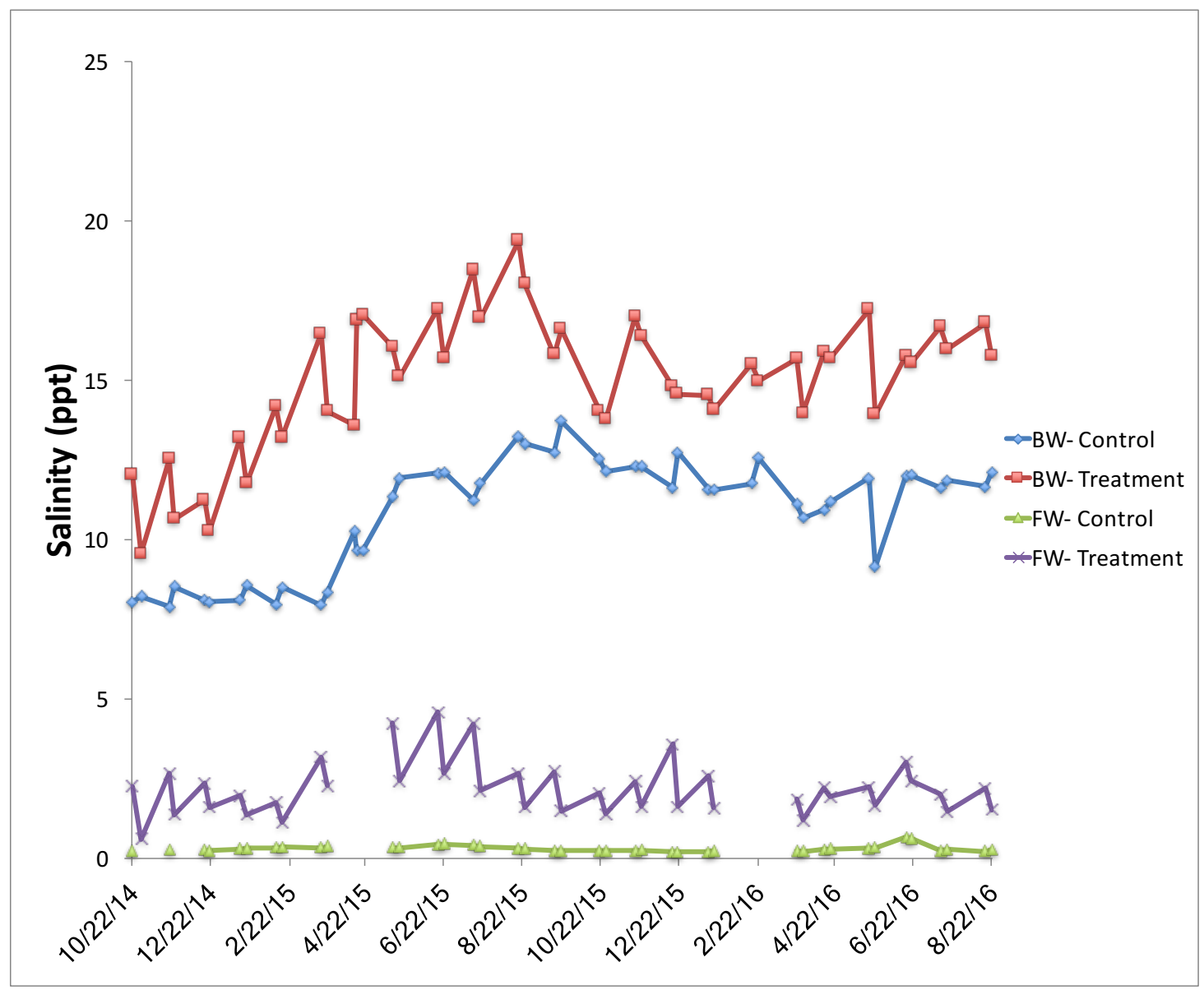

Fig S1. Porewater salinity 1 and 5 days post-dose for monthly doses over the 2-year dosing period. 

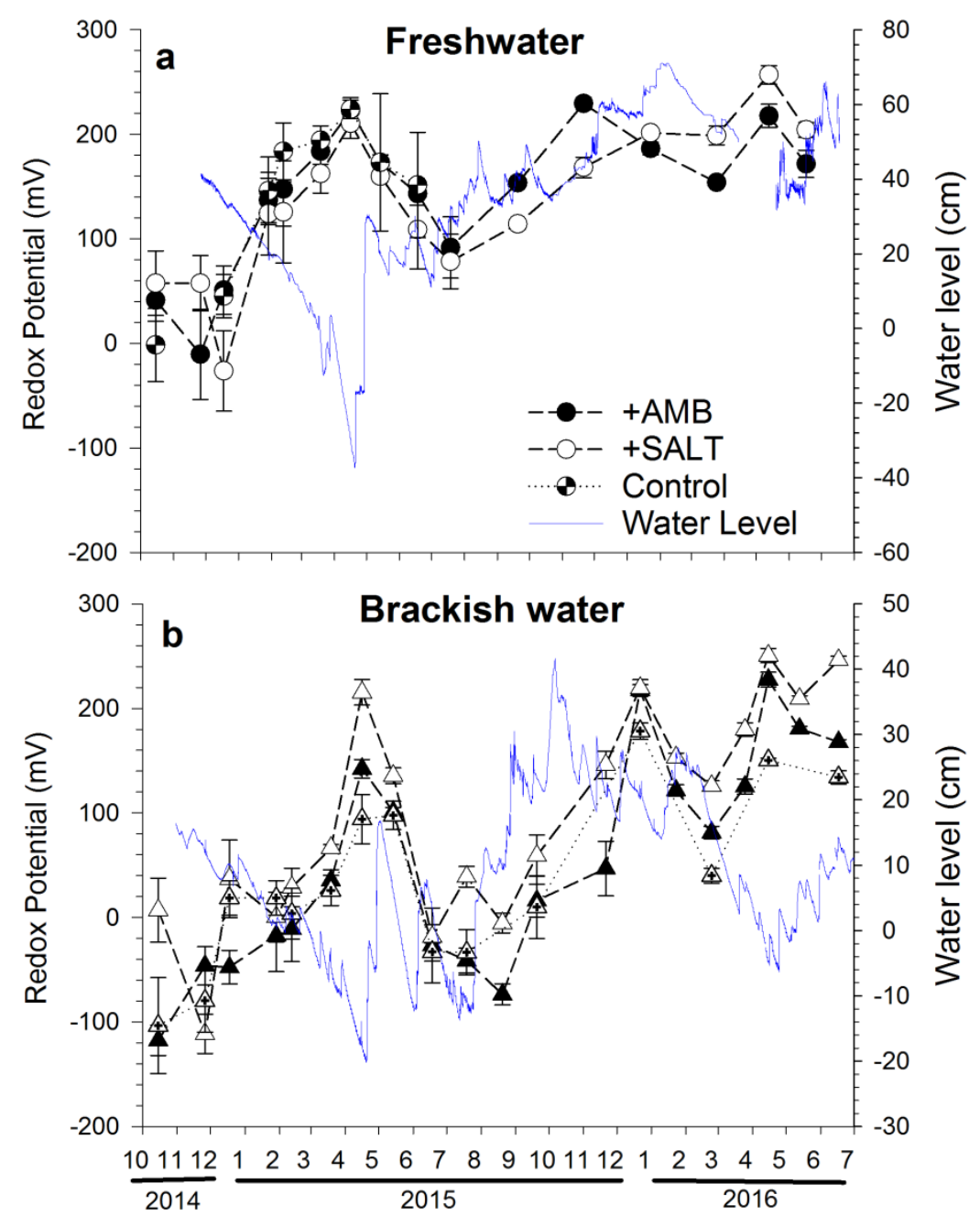

Figure S2. Mean $(n=6) \pm 1$ SE of monthly redox potential measured at $15-\mathrm{cm}$ depth from the ambient-water amended (+AMB), saltwater amended (+SALT), and "no-chamber" control (no water added) plots at the freshwater (a) and brackish water (b) sites. 
Table S1. Statistical table for the piecewise regression showing exact change-points and associated salinities in the $\mathrm{AMB}$ plots at the brackish water site. Each y corresponds to mean $\pm 1 \mathrm{SE}$ of measured porewater salinity measured at the beginning of the experiment (y1), each change-point (y2-4), and at the end of the experiment (y5). Each T corresponds to the mean $\pm \mathrm{SE}$ of the day in which the salinity change-point occurred. The $t$ and $P$ values represent the results from the piecewise regression.

\begin{tabular}{lrrrr} 
& $\begin{array}{l}\text { Coefficient [salinity } \\
\text { (ppt, y), Time (day, T)] }\end{array}$ & $\begin{array}{l}\text { Std. Error (ppt, } \\
\text { y, or days, T) }\end{array}$ & \multicolumn{1}{l}{$\boldsymbol{P}$} \\
\hline y1 & 8.0086 & 0.3621 & 22.1202 & $<0.0001$ \\
\hline y2 & 8.0029 & 0.3620 & 22.1086 & $<0.0001$ \\
y3 & 12.6756 & 0.2837 & 44.6739 & $<0.0001$ \\
\hline y4 & 11.2239 & 0.2558 & 43.8837 & $<0.0001$ \\
\hline y5 & 12.0266 & 0.3564 & 33.7459 & $<0.0001$ \\
\hline T1 & Mar 23, 2015 & 22 & 8.2580 & $<0.0001$ \\
T2 & Jun 18, 2015 & 19 & 14.3624 & $<0.0001$ \\
\hline T3 & Apr 20,2016 & 62 & 9.1625 & $<0.0001$ \\
\end{tabular}




\section{Supplemental Methods}

\section{Background}

The ecosystem carbon (C) flux measurements for this experiment were only taken in full light and in the dark and only around solar noon. This measurement is the maximum potential gross ecosystem productivity (GEP) rate and does not account for changes in light level. Therefore, fluxes must be presented as either per second or per minute. In order to extrapolate out to a daily, monthly, and then annual rate, you must apply a modeling approach that revolves around empirical relationships between photosynthesis and light, and respiration and temperature (Neubauer 2013, Wilson et al. 2015). This was done separately for both the freshwater and brackish sites in our study.

\section{Adaptation of light response curves}

We chose to adapt light response curves from Wilson et al. (2015) because the curves produced in this study were also from Gulf of Mexico sawgrass-dominated marshes. We chose to use the curves from "Week's Bay" for our freshwater site, and the curves from "Dog River" for our brackish water site. GEP measurements in the original study were taken at 4 or 5 different light levels from 3 plots each month for 1 year. For each month, we averaged the three PAR and flux measurements to create one relationship between the variables. We then calculated the percent change (PC) from the maximum for each light level and flux as:

$\mathrm{PC}=\left(\mathrm{P}-\mathrm{P}_{\mathrm{o}}\right) / \mathrm{P}_{\mathrm{o}}$

where $\mathrm{P}$ is the current parameter (PAR or GEP) and $\mathrm{P}_{\mathrm{o}}$ is the maximum measured for that time period (Table 1). 


\begin{tabular}{rrrr}
\multicolumn{1}{r|}{ PAR } & GEP & \multicolumn{1}{l}{$\begin{array}{l}\text { PAR } \\
\text { Percent } \\
\text { Change }\end{array}$} & $\begin{array}{l}\text { GEP } \\
\text { Percent } \\
\text { change }\end{array}$ \\
\hline 1414.67 & 2.98 & & \\
740.71 & 2.17 & -0.48 & -0.27 \\
675.68 & 1.80 & -0.52 & -0.39 \\
173.72 & 1.00 & -0.88 & -0.66 \\
0.00 & 0.00 & 0.00 & 0.00 \\
\hline
\end{tabular}

Table 1. Example of calculating percent change for February.

These PCs were then used to calculate the change in PAR and GEP based on measurements from that day that we measured flux. First, the maximum daily PAR value for each month from the current experiment was found from a nearby weather station (S331W, DBHydro, SFWMD). Then, the three middle light levels were assigned based on the PC from max calculated in eq. 1 (Table 2). Estimated GEP was calculated the same way using the measurement taken in full light (Table 2). This was repeated on all 12 plots $(n=6)$ for each month.

\begin{tabular}{|rrrr} 
Description & \multicolumn{1}{l}{ PAR } & \multicolumn{1}{l}{ GEP } & \multicolumn{1}{c}{ Description } \\
\hline Max PAR & $\mathbf{1 4 9 7}$ & 3.71 & GEP measured in full light \\
\hline Calculated PAR & $\mathbf{7 8 3 . 8 2 0 3 5 8 2}$ & 2.697606332 & Calculated GEP \\
Calculated PAR & $\mathbf{7 1 5 . 0 0 1 5 0 9 2}$ & 2.247015708 & Calculated GEP \\
\hline Calculated PAR & $\mathbf{1 8 3 . 8 3 0 4 7 1 3}$ & 1.249720552 & Calculated GEP \\
\hline & 0 & 0 &
\end{tabular}

Table 2. Estimated GEE for plot 5 in February 2015 based on PCs in PAR and GEP relative to the reference marsh. The calculated PAR and GEP are defined in Table 1.

After the relationships between PAR and GEP were calculated from each plot for each month, hyperbolic curves were fit to GEP vs. PAR for each according to:

$$
G E P=[(a \times I) /(b+I)]
$$


where $I$ was incident irradiance $\left(\mu \mathrm{mol} \mathrm{m} \mathrm{m}^{-2} \mathrm{~s}^{-1}\right)$, GEP was total photosynthetic uptake ( $\mu \mathrm{mol} \mathrm{CO} \mathrm{Cm}^{-2} \mathrm{~s}^{-1}$ ), and $a$ and $b$ were empirically derived constants (Whiting et al. 1992). Best-fit regressions for the constants $a$ and $b$ were derived for each plot on a monthly basis using curve-fitting routine in Sigmaplot (v. 13.0, Systat Software Inc., San Jose, CA). Gross ecosystem productivity was calculated every 15 min by taking irradiance data averaged over 15 min time intervals (DBHydro, SFWMD) and integrating the results over a period in which PAR was above $10 \mu \mathrm{mol} \mathrm{m} \mathrm{m}^{-2} \mathrm{~s}^{-1}$ to obtain a daily gross photosynthetic uptake rate. This was modeled for every day of the year for two years, with each month using the derived $a$ and $b$ constants for that month, to get an annual rate.

\section{Creation of respiration versus temperature curves}

In order to model annual ecosystem respiration (ER), empirical relationships between ER and temperature were developed. Because seasonal hydrology greatly affects ER, ER vs. temperature relationships were developed separately for months when surface water was above the soil surface and months when surface water receded below the soil surface.

$\mathrm{CO}_{2}$ fluxes taken in the dark from all sampling months with similar hydrology were regressed against air temperature (S331W, DBHydro, SFWMD) at the time of the measurement. Data were fitted to exponential curves using curve-fitting routine in SigmaPlot:

$E R_{C O 2}=A e^{B \times T}$

where $\mathrm{ER}_{\mathrm{CO} 2}$ was the ecosystem respiration of $\mathrm{CO}_{2}$ rate $\left(\mu \mathrm{mol} \mathrm{C} \mathrm{m}^{-2} \mathrm{~s}^{-1}\right)$, $\mathrm{T}$ was air temperature $\left({ }^{\circ} \mathrm{C}\right)$, and $A$ and $B$ were empirically derived constants (Miller et al. 2001). 
The curves allowed for the extrapolation of $\mathrm{CO}_{2}$ respiration rates to all temperatures encountered during the sampling year. Two $\mathrm{ER}_{\mathrm{CO} 2} \mathrm{vs}$. T relationships was created for each site, one for months when the soil surface was inundated, and one for when water receded below the soil surface. These environmental relationships were then combined with air temperature data measured every $15 \mathrm{~min}$ (S331W, DBHydro, SFWMD) for $24 \mathrm{~h}$ to calculated daily $\mathrm{ER}_{\mathrm{CO} 2}$. Similarly, daily-integrated NEE was calculated every $15 \mathrm{~min}$ from GEE and $\mathrm{ER}_{\mathrm{CO} 2}$ rates:

$N E E=G E E+E R_{C O 2}$

where a positive NEE rate indicated net $\mathrm{C}$ assimilated through photosynthesis. The annual rate presented in this study is the average between the two years in which measurements were taken.

\section{Supplemental Literature Cited}

Miller, W. D., S. C. Neubauer, and I. C. Anderson. 2001. Effects of sea level induced disturbances on high salt marsh metabolism. Estuaries 24:357-367.

Neubauer, S. C. 2013. Ecosystem responses of a tidal freshwater marsh experiencing saltwater intrusion and altered hydrology. Estuaries and Coasts 36:491-507.

Whiting, G. J., D. S. Bartlett, S. M. Fan, P. S. Bakwin, and S. C. Wofsy. 1992. Biosphere atmosphere $\mathrm{CO} 2$ exchange in tundra ecosystems - community characteristics and relationships with multispectral surface reflectance. Journal of Geophysical Research-Atmospheres 97:16671-16680.

Wilson, B. J., B. Mortazavi, and R. P. Kiene. 2015. Spatial and temporal variability in carbon dioxide and methane exchange at three coastal marshes along a salinity gradient in a northern Gulf of Mexico estuary. Biogeochemistry 123:329-347. 
CHAPTER II

BALANCING NUTRIENT SUBSIDY AND SALINITY STRESS: SHORT- AND LONG-TERM EFFECTS OF SALTWATER INTRUSION ON FRESHWATER WETLAND ECOSYSTEM FUNCTIONS 
Running Head: Saltwater intrusion in a freshwater wetland

Title: Balancing nutrient subsidy and salinity stress: short- and long-term effects of saltwater intrusion on freshwater wetland ecosystem functions

Authors: Benjamin J. Wilson, Shelby Servais, Sean P. Charles, Viviana Mazzei, Evelyn E. Gaiser, John S. Kominoski, Jennifer H. Richards, and Tiffany G. Troxler

\section{Key Words}

sea-level rise, Florida Everglades, phosphorus, carbon cycling, coastal marsh 


\begin{abstract}
Environmental perturbations drive ecosystem functions through interacting subsidies and stressors. Effects of perturbations can switch from subsidy to stress, or vice versa, depending on the type and/or duration. Here, we assessed how coastal wetland ecosystem functioning responds to saltwater intrusion, a perturbation that is expected to greatly impact these ecosystems, given accelerating sea level rise. In wetland mesocosms, we continuously exposed macrophyte and peat soil monoliths from a freshwater Cladium jamaicense (sawgrass) marsh to two factors associated with saltwater intrusion in karstic ecosystems: elevated loading of salinity (a stress) and phosphorus (P) inputs (a subsidy). We took repeated measures using a 2 × 2 factorial experimental design $(n=6)$ with treatments composed of elevated salinity ( $\sim 9 \mathrm{ppt}), \mathrm{P}$ loading $\left(0.45 \mathrm{mg} \mathrm{P} \mathrm{d}^{-1}\right)$, or combination of both and looked at changes in water physicochemistry, ecosystem productivity, and plant biomass change over 2 years to assess short- and long-term subsidy-stress responses to saltwater intrusion. In the short-term, plants primarily exhibited subsidy effects with simulated saltwater intrusion (salinity $+\mathrm{P}$ ), driven by increased P availability. Despite relatively high salinity levels ( $\sim 9 \mathrm{ppt})$, gross ecosystem productivity (GEP), net ecosystem productivity (NEP), and aboveground biomass were significantly higher in the elevated salinity $+\mathrm{P}$ treated monoliths compared to the freshwater controls. Salinity stress effects became evident over time; although still higher than freshwater controls, GEP and NEP were significantly less in the elevated salinity $+\mathrm{P}$ treatment compared to the $+\mathrm{P}$-only treatment. However, after 2 years of continuous exposure to elevated salinity, live root biomass was lower, regardless of whether $\mathrm{P}$ was added. Our results suggest that, although aboveground primary productivity may initially
\end{abstract}


be stimulated by saltwater intrusion, long-term exposure to elevated salinity will negatively impact belowground peat structure and stability. In addition, given that we found a strong negative response of root biomass but a strong positive response of aboveground biomass productivity to elevated salinity $+\mathrm{P}$, the response variable measured is an important factor to consider when determining if ecosystem functioning is experiencing a subsidy or stress response to environmental perturbations.

\section{INTRODUCTION}

Environmental perturbations are common in coastal ecosystems and have the ability to strongly impact ecosystem functioning (Odum et al. 1995, Paerl 2006, Hanley et al. 2017). Although perturbations are typically viewed as a unimodal curve along a single axis (Odum et al. 1979), they can vary in frequency, magnitude, and direction of effect, which can strongly impact ecosystem processes, such as the flow of carbon (C) through the system (Shea et al. 2004, Hanley et al. 2017). For example, stochastic perturbations, such as hurricanes, can initially act as a stressor and negatively impact ecosystem functioning through defoliation and plant mortality (Cahoon et al. 2003, Zhang et al. 2008, Smith et al. 2009). However, over the long term, nutrient-rich sediments deposited by the same hurricane can act as a subsidy and positively impact ecosystem functioning (Castaneda-Moya et al. 2010, Barr et al. 2012, Danielson et al. 2017). Perturbations occurring as presses (i.e., continuous exposure) can have the opposite effect. For example, low to moderate press perturbations, such as flooding in riverine systems, can act as a subsidy, but high levels of flooding over a longer duration can act as a stress (Odum et al. 1979, Poff 2002, Wright et al. 2015). Understanding 
functional responses and their direction to environmental perturbations is critical in ecosystems susceptible to rapid changes in climate.

Wetlands store $20-30 \%$ of global soil C, despite occupying only $\sim 5-8 \%$ of the earth's surface, because of their high productivity and low decomposition rate (Mitsch and Gosselink 2007, Nahlik and Fennessy 2016). Wetland functions that determine C storage, however, are highly susceptible to perturbations, such as changes in hydrology, water chemistry, and vegetation regime (Deegan et al. 2012, Webster et al. 2013, Bernal et al. 2017). As sea level rise (SLR) accelerates, one perturbation likely to become more frequent is saltwater intrusion. Saltwater intrusion into historically freshwater coastal marshes will greatly affect wetland productivity and biogeochemical cycling. Saltwater can be a stressor for freshwater wetland vegetation and has been associated with decreased species richness (Sharpe and Baldwin 2012, Neubauer 2013), gross ecosystem productivity (Neubauer 2013, Wilson et al. in review), and primary production (Delaune et al. 1987, Spalding and Hester 2007, Herbert et al. 2015). In non-tidal, non-riverine, peat-dominated wetlands that do not receive an allochthonous sediment supply, a decline in productivity can be coupled with a decrease in soil organic matter inputs, which can negatively affect the stability of the marsh (Delaune et al. 1994, Baustian et al. 2012). Little work has been done to examine how ecosystem $\mathrm{C}$ processing in freshwater coastal peat marshes respond to saltwater intrusion, and whether elevated salinity makes these marshes more vulnerable to collapse (Wanless and Vlaswinkel 2005).

Saltwater intrusion into coastal wetlands occurs through two main pathways: overland incursion through tides or storm surge and groundwater upwelling (Herbert et al. 2015). In karstic systems, such as the Florida Everglades, porous limestone creates a 
conduit for large-scale groundwater upwelling (Price et al. 2006). In freshwater marshes not adjacent to tidal creeks, groundwater upwelling of saline water is the most likely mechanism of saltwater intrusion into inland marshes (Price et al. 2006). This upwelling can have a large effect on the groundwater chemistry. Phosphorus commonly adsorbs to calcium carbonate bedrock, and an influx of saline groundwater can react with the limestone, causing $\mathrm{P}$ desorption and increasing water soluble reactive $\mathrm{P}$ (SRP) concentrations (Price et al. 2006, Flower et al. 2017). In oligotrophic wetlands, this newly available SRP can act as a subsidy in P-limited wetlands. Microbial community structure and processes can respond rapidly to nutrient subsidies (Corstanje et al. 2007). For example, in oligotrophic soils, $\mathrm{P}$ enrichment has been shown to stimulate microbial C processing and soil $\mathrm{CO}_{2}$ production, which leads to a higher amount of $\mathrm{C}$ breakdown and faster turnover (Amador and Jones 1993, DeBusk and Reddy 1998, Wright and Reddy 2007, Medvedeff et al. 2015). Additionally, P enrichment can stimulate plant growth and biomass, thus providing organic inputs to the soil, although this response is usually much slower than the microbial response and can take years to manifest (Chiang et al. 2000, Noe et al. 2002). Nutrient additions can also change biomass allocation within wetland plants, generally causing more shoot relative to root production (Poorter and Nagel 2000). Given that peatlands rely on this input of autochthonous organic material for soil maintenance and stabilization, an influx of nutrients can potentially destabilize and collapse the marsh because of less root production (Deegan et al. 2012).

Saltwater intrusion into coastal, karstic wetlands provides an excellent case study to test perturbation theory given that exposure to saltwater is expected to act as both a subsidy $(\mathrm{P})$ and a stress (elevated salinity) on the biological communities within these 
ecosystems (Odum et al. 1979). Although there have been numerous studies on the effects of nutrient loading or elevated salinity alone on coastal wetlands, few very have looked at the interaction of subsidies and stressors that can occur with saltwater intrusion (Macek and Rejmankova 2007, Rejmankova and Macek 2008). The goal of this study was to determine how ecosystem productivity, biogeochemical cycling, and the greenhouse gas carbon balance respond to simulated saltwater intrusion into an oligotrophic freshwater karstic wetland. We chose the Florida Coastal Everglades as our study site because $60 \%$ of Everglades National Park (ENP) is at or below $0.9 \mathrm{~m}$ in elevation, a region highly susceptible to saltwater intrusion (Pearlstine et al. 2010). We hypothesized that increased salinity would initially stimulate soil $\mathrm{CO}_{2}$ efflux, but that continuous exposure to elevated salinity would suppress soil $\mathrm{CO}_{2}$ efflux over time. Conversely, we hypothesized that $\mathrm{P}$ addition would increase soil $\mathrm{CO}_{2}$ efflux. We also hypothesized that increased salinity would reduce gross ecosystem productivity (GEP) and net ecosystem productivity (NEP), whereas $\mathrm{P}$ would increase GEP and NEP. We tested the subsidy-stress hypothesis that the interaction of salinity and $\mathrm{P}$ would offset lower GEP and NEP from increased salinity, resulting in no change in GEP and NEP compared to controls. Lastly, we hypothesized that the decrease in $\mathrm{CH}_{4}$ efflux as a result of elevated salinity would be greater than the increase in $\mathrm{CH}_{4}$ efflux with added $\mathrm{P}$, shifting the greenhouse gas carbon balance. 


\section{MATERIALS AND METHODS}

$\underline{\text { Study site and experimental facilities }}$

In July 2014, twenty-four plant-peat soil monoliths $(60 \mathrm{~cm} \mathrm{~L} \mathrm{x} 40 \mathrm{~cm} \mathrm{~W} \mathrm{x} 30 \mathrm{~cm}$ H) were collected from a freshwater marsh in the Everglades near Water Conservation Area 3B $\left(25^{\circ} 46^{\prime} 07.4^{\prime \prime} \mathrm{N}, 80^{\circ} 28^{\prime} 56.7^{\prime \prime} \mathrm{W}\right)$ that was dominated by a dense stand of Cladium jamaicense (sawgrass). We extracted the peat monoliths using shovels to cut out a piece of marsh larger than a mesh-lined container $(50 \mathrm{~cm} \mathrm{~L} \times 40 \mathrm{~cm} \mathrm{~W} \times 30 \mathrm{~cm} \mathrm{H})$. We then shaved the edges of the peat monoliths to the size of the container and placed each into mesh-lined containers filled with an array of $2.5 \mathrm{~cm}$ diameter holes to allow for water exchange but keeping soil structure intact. Monoliths were then transported to an outdoor mesocosm facility at the Florida Bay Interagency Science Center (FBISC) in Key Largo, FL.

Once on site, monoliths were placed into polycarbonate boxes $(69 \mathrm{~cm} \mathrm{~L} \mathrm{x} 51 \mathrm{~cm}$ $\mathrm{W} \times 53 \mathrm{~cm} \mathrm{H})$ and randomly assigned to one of four treatments $(n=6)$ interspersed among six large concrete tanks (2.2 m L x $0.8 \mathrm{~m} \mathrm{~W} \mathrm{x} 0.7 \mathrm{~m} \mathrm{H}$; Fig. Sa). Each monolith was contained within its own water source and did not interact with any surrounding monoliths. The monoliths were allowed to acclimate for 7 months under inundated freshwater conditions before treatment manipulations and measurements began. The four treatments were Fresh (freshwater, no P), Fresh $+\mathrm{P}$ (freshwater with added P), Salt (elevated salinity, no P), and Salt $+\mathrm{P}$ (elevated salinity with added $\mathrm{P}$ ). A partition was inserted between the no $\mathrm{P}$ and $+\mathrm{P}$ treatments to avoid possible contamination of water from one monolith splashing into another (Fig. S1). 
In February 2015, water in the Salt treatments was added in gradually incrementing amounts of salinity over 2 months to hit our target salinity of $7 \mathrm{ppt}$, while P (2.25 $\mathrm{mg} \mathrm{L}^{-1}$ diluted phosphoric acid) was pumped to the appropriate treatments at a rate of $0.14 \mathrm{~mL}^{-1} \mathrm{~min}^{-1}\left(0.454 \mathrm{mg} \mathrm{P}\right.$ day $^{-1}, \sim 2 \mathrm{x}$ ambient load; (King and Richardson 2008). Dosing concentrations of salinity were adjusted monthly depending on porewater salinity in order to maintain a treatment level of $\sim 7-10 \mathrm{ppt}$. Salinity was controlled by mixing water weekly to desired experimental salinity concentrations from four 2,000-gallon head tanks, two with freshwater and two with saltwater. Two liters of this water was manually added 2-3 times per week to each box in order to keep the monoliths completely inundated. Freshwater was collected from a nearby canal and had similar nutrient concentrations found in freshwater portions of the Everglades $\left(\mathrm{C}-111 ; 25^{\circ} 17^{\prime} 31.74 " \mathrm{~N}\right.$, $\left.80^{\circ} 27^{\prime} 21.59^{\prime \prime} \mathrm{W}\right)$. Saltwater head tanks were equipped with a pump to draw water from adjacent Florida Bay. Nutrient concentrations of water added to the fresh and salt monoliths are reported in Table S1. Notably, the only significant difference between the two source waters was that bay water had higher salt concentrations, although $\mathrm{NH}_{4}^{+}$was $\sim 4 \mathrm{x}$ higher in the freshwater and SRP was $\sim 3 \mathrm{x}$ higher in the bay water (Table S1).

\section{Water physicochemistry and soil redox}

Surface water in each monolith was collected monthly using a 60-mL syringe and placed into new, unused plastic bottles. Prior to the experiment, a porewater sipper with an air stone (4-cm long x 1-cm diameter) was inserted to $15-\mathrm{cm}$ depth near the middle of each monolith. Porewater was collected weekly using a $60-\mathrm{mL}$ syringe by placing suction on the sipper and evacuating at least 1 sipper volume before sampling. Filtered samples 
were run through a $0.7-\mu \mathrm{m}$ glass fiber filters (GFF) before being placed into a separate bottle. At the time of collection, temperature $\left({ }^{\circ} \mathrm{C}\right)$, salinity (ppt), and $\mathrm{pH}$ were measured on samples of freshwater source, saltwater source, and monolith surface water using a YSI Model 600 XL (Xylem, Inc., Yellow Springs, OH, USA). All water samples were stored at $-20^{\circ} \mathrm{C}$ until analysis at the Southeast Environmental Research Center Nutrient Analysis Laboratory at Florida International University. Unfiltered surface water was analyzed for total $\mathrm{N}(\mathrm{TN})$, total P (TP), and total organic C (TOC). Filtered porewater and filtered surface water samples were analyzed for dissolved organic C (DOC), dissolved inorganic nitrogen (DIN; $\mathrm{NO}_{3}^{-}, \mathrm{NO}_{2}^{-}, \mathrm{NH}_{4}{ }^{+}$), and soluble reactive $\mathrm{P}$ (SRP). DIN, TN, TP, and SRP samples were analyzed on a Alpkem RFA 300 auto-analyzer (OI Analytical, College Station, TX, USA); TOC and DOC were analyzed with a Shimadzu 5000 TOC Analyzer (Shimadzu Scientific Instruments, Columbia, MD, USA). Sulfide (HS) was measured using standard methods (McKee et al. 1988).

Oxidation-reduction potential was measured using standard techniques (Faulkner et al. 1989). Briefly, three platinum-tipped probes were inserted to 5-cm depth in each monolith and allowed to equilibrate for 30 minutes until measurements were taken. Electrode potentials were corrected using a reference electrode and standard electrode potentials. Soil bulk density was calculated by taking one core $\left(2.4 \mathrm{~cm}^{2}\right.$ x $30 \mathrm{~cm}$ depth) from each monolith. The core was separated into $10-\mathrm{cm}$ sections, dried at $60^{\circ} \mathrm{C}$, and weighed. The bulk density for each soil depth was calculated as the dry weight divided by the volume of the core segment. 


\section{Plant biomass and elemental stoichiometry}

Sawgrass aboveground net primary productivity (ANPP) was measured every two months non-destructively following methods described in Daoust \& Childers (1998). Briefly, sawgrass plants were tagged and measured bimonthly for the number of live and dead leaves, shoot height, and culm diameter. Change in sawgrass aboveground biomass and ANPP were calculated using previously derived allometric relationships between plant height, culm diameter, and biomass (Childers et al. 2006). Live belowground biomass was determined by taking one core $\left(2.4 \mathrm{~cm}^{2} \times 30 \mathrm{~cm}\right.$ depth) from each monolith at the end of the experiment, separating it into $10-\mathrm{cm}$ sections, and storing it at $4{ }^{\circ} \mathrm{C}$ until processing (within two weeks). The live roots, those which floated in water, were separated by washing through a $1-\mathrm{mm}$ sieve, dried at $60^{\circ} \mathrm{C}$, and weighed. Sawgrass leaf (year $1 \& 2$ ) and root (year 2) samples for each monolith were dried, ground, and subsampled for analysis of C, N (Zimmermann and Keefe 1997), and P (Solorzano and Sharp 1980) content.

\section{$\underline{\text { Soil } \mathrm{CO}_{2}} \underline{\text { and } \mathrm{CH}_{4}} \underline{\text { fluxes }}$}

One 10-cm diameter PVC collar was installed 5-cm into the soil of each peat monolith for soil $\mathrm{C}$ efflux measurements. Soil $\mathrm{CO}_{2}$ efflux ( $n=6$ per treatment) was measured monthly near noon between Feb 2015 and Sep 2016 on all 24 monoliths using a portable infrared gas analyzer (LI-8100, LI-COR, Lincoln, NE, USA) equipped with a 10-cm diameter chamber. Each flux measurement was taken for 120s. The flux was calculated as the linear slope of $\mathrm{CO}_{2}$ concentration over time. Soil $\mathrm{CH}_{4}$ efflux was measured monthly between Feb and Nov 2015 from a subset ( $n=4$ per treatment) of 
monoliths using the LI-8100 modified to collect a subset of air for trace gas sampling. The chamber was sealed and, immediately following closure, $25-\mathrm{mL}$ of gas was withdrawn using a $60-\mathrm{mL}$ syringe from a port in-line with the instrument. After $15 \mathrm{~min}$, another gas sample was collected. The gas was sealed in a $20-\mathrm{mL}$ evacuated glass vial and transported back to the lab for analysis. Samples were run within 2 days of collection on a gas chromatograph (Shimadzu Scientific Instruments GC 8A, Columbia, MD, USA) fitted with a flame ionization detector (FID). Methane flux was calculated as the slope of $\mathrm{CH}_{4}$ concentration over time. No soil gas flux measurements were taken in March, April, and December 2015, or January 2016 because of equipment failure.

\section{$\underline{\text { Ecosystem } \mathrm{CO}_{2}} \underline{\text { flux }}$}

Measurements of ecosystem $\mathrm{CO}_{2}$ exchange were conducted bimonthly from Dec 2015 to Jan 2017 on a subset ( $n=4$ per treatment) of monoliths. Prior to each measurement, a polycarbonate collar $(67 \mathrm{~L} \mathrm{x} 49 \mathrm{~W}$ x $58 \mathrm{H} \mathrm{cm})$ was inserted between the container holding the monolith and the box containing the monolith and surrounding water. The collar was fitted with a foam platform on which the chamber could sit while enclosing both the plants and soil. The clear polycarbonate chamber $(53 \mathrm{~L}$ x $38 \mathrm{~W}$ x 150 $\mathrm{H} \mathrm{cm}$ ) was placed onto the foam platform and sealed using bungee cords to ensure an airtight seal during measurements. A pump sent air from the chamber to an infrared gas analyzer (LI-840, LI-COR) and back to the chamber. The chamber was allowed to equilibrate for 2 mins, then $\mathrm{CO}_{2}$ concentration was measured every second for 3 mins in both full light and in the dark (Wilson et al. in review). The flux was calculated as the linear slope of $\mathrm{CO}_{2}$ concentration over time. Net ecosystem productivity (NEP) was 
measured in full light, whereas ecosystem respiration of $\mathrm{CO}_{2}\left(\mathrm{ER}_{\mathrm{CO} 2}\right)$ was measured in the dark immediately after light measurements by covering the chamber with a dark cloth that blocked out all sunlight. Gross ecosystem productivity (GEP) was calculated from $\mathrm{NEP}$ and $\mathrm{ER}_{\mathrm{CO} 2}$ as:

$-G E P=-N E P-E R_{C O 2}$

where NEP is instantaneous $\mathrm{CO}_{2}$ flux $\left(\mu \mathrm{mol} \mathrm{m} \mathrm{m}^{-2}\right)$ in light and $\mathrm{ER}_{\mathrm{CO} 2}$ is the $\mathrm{CO}_{2}$ flux in the dark. Ecosystem flux measurements were not taken from February to November 2015 because the experimental setup had not yet been equipped to handle these kinds of measurements.

Global greenhouse gas carbon balance contributions

The contribution of experimental peat-sawgrass monoliths to greenhouse gas $\mathrm{C}$ balance, and how it changes with added salinity and P, was estimated by comparing the overall mean NEP rates to overall mean soil $\mathrm{CH}_{4}$ efflux $\left(\mathrm{mol} \mathrm{mol}^{-1}\right)$ using the sustainedflux global warming potential (SGWP) of 45 for efflux and 203 for uptake for a 100 year time frame (Neubauer and Megonigal 2015). A new calculated NEP based on the SGWP was calculated as:

Calculated $\mathrm{NEP}=\mathrm{NEP}-\left(\mathrm{CH}_{4} * \mathrm{SGWP}\right)$

\section{$\underline{\text { Statistical Analyses }}$}

Statistical analyses were performed using R (R Core Team 2017). Differences in porewater physicochemistry, C flux, sawgrass biomass, and sawgrass ANPP among treatments were determined through linear mixed effects models (R package "nlme", 
Pinheiro et al. 2017). Treatment and date were set as fixed factors, and monolith number was set as a random factor. Following the mixed effects model, within-date differences in C flux, biomass, and ANPP were assessed with a standard least squares ANOVA, with date as a model effect (R package "Ismeans", Lenth 2017). The effect of salinity and P on the overall mean C flux, biomass, ANPP, surface and source water physicochemistry, soil bulk density, and belowground biomass was determined using a two-way ANOVA, followed by a Tukey's HSD post-hoc test to determine differences among treatments. Normality and homoscedasticity were tested by visually inspecting plotted residuals, and data were log-transformed to increase heteroscedasticity when necessary. All analyses used a significance factor of $\alpha=0.05$.

\section{RESULTS}

Water physicochemistry and soil redox

Mean porewater salinity in the salinity treatments over the duration of the experiment was $8.83 \pm 0.27 \mathrm{ppt}$ (Table 1). In total, $84,933 \pm 1,717 \mathrm{~g} \mathrm{~m}^{-3}$ of salt was added to each salinity treated sawgrass-peat monolith and $6.17 \pm 0.01 \mathrm{~g} \mathrm{~m}^{-3}$ of $\mathrm{P}$ was added to each P treated sawgrass-peat monolith. Surface water DOC, $\mathrm{TOC}, \mathrm{NO}_{2}{ }^{-}$, and $\mathrm{TN}$ were all higher in the saltwater amended monoliths (Table S2; $P<0.05$ ). Surface water SRP and TP were higher with added $\mathrm{P}$ only in the saltwater monoliths. Porewater $\mathrm{NO}_{2}{ }^{-}, \mathrm{NH}_{4}{ }^{+}$, DOC, SRP, and $\mathrm{HS}^{-}$were all higher in the saltwater amended monoliths $(P<0.05)$ regardless of $\mathrm{P}$ addition ( $P>0.05$; Table 1 , Table 2$)$. Soil bulk density was lower in the Fresh $+\mathrm{P}$ and Salt $+\mathrm{P}$ monoliths $\left(0.089 \pm 0.012\right.$ and $0.079 \pm 0.011 \mathrm{~g} \mathrm{~cm}^{-3}$, respectively $)$ compared to the Fresh and Salt monoliths $\left(0.102 \pm 0.012\right.$ and $0.110 \pm 0.011 \mathrm{~g} \mathrm{~cm}^{-3}$, 
respectively) $\left(F_{(1,60)}=4.27, P=0.043\right)$, whereas salinity had no effect $\left(F_{(1,60)}=0.01\right.$, $P=0.907)$. There was a significant effect of salinity, but not $\mathrm{P}$, on soil redox potential (Table 2). Averaged over the duration of the experiment, soil redox potential at $15-\mathrm{cm}$ depth was $+185.1 \pm 6.5,+180.4 \pm 6.5,+169.9 \pm 8.2 \mathrm{mV}$, and $+147.5 \pm 8.1 \mathrm{mV}$ in the Fresh, Fresh $+\mathrm{P}$, Salt, and Salt $+\mathrm{P}$ treatments, respectively.

Plant biomass and elemental stoichiometry

Sawgrass aboveground biomass remained relatively constant over the two-year study period in both the Fresh and Salt treatments, whereas aboveground biomass increased over time in the Fresh $+\mathrm{P}$ and Salt $+\mathrm{P}$ treatments (Fig. 1). On average, $\mathrm{P}$ had a significant effect on aboveground biomass and ANPP (Table 2). Beginning in June 2016, there was higher aboveground biomass in the Fresh $+\mathrm{P}$ treatment (LSMEANS, $P<0.05$ ). There was no difference among treatments in mean ANPP during the first year (Fig. 2, Tukey HSD, $P>0.05)$. During the second year, ANPP was higher in both Fresh $+\mathrm{P}$ and Salt $+\mathrm{P}$ amended treatments, but this effect was only significant in the Fresh treatment (Tukey HSD, $P=0.007$ ). Sawgrass leaf stoichiometry was relatively consistent across treatments and years (Table S3). Leaf C and $\mathrm{N}$ content did not vary across treatments, and leaf $\mathrm{P}$ content was significantly higher in the Salt $+\mathrm{P}$ treatment compared to the Fresh treatment only during the first year (Tukey HSD, $P=0.002$ ). There was no interactive effect of salinity and P on either aboveground biomass or ANPP (Table 2).

Belowground biomass collected at the end of the study was significantly affected by elevated salinity $\left(F_{(1,67)}=8.50, P=0.004\right)$ but not by added $\mathrm{P}\left(F_{(1,67)}=2.58, P=0.112\right)$. Elevated salinity decreased live root biomass by 32 and $53 \%$ in the Salt and Salt $+\mathrm{P}$ 
treatments, respectively (Fig, 3). The ratio of above- to below-ground biomass increased with both elevated salinity and added P (Fig. 3).

\section{$\underline{\text { Soil } \mathrm{CO}_{2}} \underline{\text { and } \mathrm{CH}_{4}} \underline{\underline{\text { fluxes }}}$}

Soil $\mathrm{CO}_{2}$ efflux was dynamic across time but showed a strong trend of higher fluxes during warmer months (Fig, 4). There was no difference in $\mathrm{CO}_{2}$ efflux among treatments during the first month, but within three months, elevated salinity began to depress $\mathrm{CO}_{2}$ efflux (Fig. 4). On average, elevated salinity decreased soil $\mathrm{CO}_{2}$ efflux by $41 \%$ and $61 \%$ within the Salt and Salt $+\mathrm{P}$ monoliths, respectively, whereas adding P had no effect (Table 2, Table 3). Soil $\mathrm{CH}_{4}$ efflux showed a seasonal trend with higher efflux occurring during the warmer summer and fall months (Fig. 5). Elevated salinity decreased $\mathrm{CH}_{4}$ efflux by $100 \%$ and $96 \%$ in the Salt and Salt $+\mathrm{P}$ monoliths, respectively, (Table 2, Table 3). Adding P increased soil $\mathrm{CH}_{4}$ efflux by $403 \%$ in the Fresh $+\mathrm{P}$ monoliths, although this result was only marginally significant due to high variability $(P=0.057$, Table 2$)$.

$\underline{\text { Ecosystem } \mathrm{CO}_{2}} \underline{\underline{\text { flux }}}$

When ecosystem flux measurements began in December 2015, GEP and NEP were higher in the $\mathrm{P}$ amended treatments (LSMEANS, $P<0.001$ ) with no difference with added salinity (LSMEANS, $P=0.612$ ), whereas there was no effect of either salt or $\mathrm{P}$ on $\mathrm{ER}_{\mathrm{CO} 2}$ (LSMEANS, $P>0.05$; Fig. 6). By the end of the two-year experiment, there was no difference in GEP, NEP, or $\mathrm{ER}_{\mathrm{CO} 2}$ in the Salt treatment (LSMEANS, $P>0.05$ ), yet adding $\mathrm{P}$ caused GEP, NEP, and $\mathrm{ER}_{\mathrm{CO} 2}$ to be higher in both the Fresh $+\mathrm{P}$ and Salt $+\mathrm{P}$ monoliths 
(LSMEANS, $P<0.05$ ). Over the course of the entire experiment, added $\mathrm{P}$ had a significant effect on NEP $\left(F_{(1,124)}=56.47, P<0.001\right)$ whereas elevated salinity had no effect $\left(F_{(1,124)}=2.40, P=0.123\right)$. Together, there was an interactive effect of salinity and $\mathrm{P}$ on NEP and GEP, but not $\mathrm{ER}_{\mathrm{CO} 2}$ (Table 2). Mean NEP was significantly greater in the Fresh $+\mathrm{P}$ monoliths than the Salt $+\mathrm{P}$ monoliths (Tukey's HSD, $P=0.027$ ). Cumulatively, added P increased GEP by $138 \%$ and $67 \%$, ER $\mathrm{R}_{\mathrm{co} 2}$ by $121 \%$ and $92 \%$, and NEP by $136 \%$ and $62 \%$ in the Fresh $+\mathrm{P}$ and Salt $+\mathrm{P}$ monoliths, respectively (Table 3).

Contributions to global greenhouse carbon balance

Changes in contributions to the global greenhouse $\mathrm{C}$ balance occurred with the addition of both salinity and $\mathrm{P}$. The $\mathrm{CH}_{4}: \mathrm{CO}_{2}$ ratio was much smaller in the Salt and Salt + P monoliths compared to the Fresh and Fresh $+P$ monoliths (Table 4). Elevated P greatly increased the $\mathrm{CH}_{4}: \mathrm{CO}_{2}$ ratio in the freshwater monoliths, but had no effect in the elevated salinity monoliths. As a result, although the Fresh $+\mathrm{P}$ treatment had the highest measured NEP, increased $\mathrm{CH}_{4}$ emissions associated with elevated $\mathrm{P}$ offset the increase in $\mathrm{CO}_{2}$ uptake based on the SGWP (Table 4). Net ecosystem productivity, calculated incorporating the SGWP of $\mathrm{CH}_{4}$, showed that the Salt $+\mathrm{P}$ monoliths had the greatest NEP among all treatments.

\section{DISCUSSION}

Perturbation theory states that, although the input of some additional resource to an ecosystem may initially act as a subsidy, too much input over time may adversely affect ecosystem functioning (Odum et al. 1979). This theory is exemplified by saltwater 
intrusion into karstic, freshwater wetlands which provides a supply of the limitingnutrient, phosphorus (Price et al. 2006, Flower et al. 2017) while simultaneously introducing a physical stressor in the form of elevated salinity (Herbert et al. 2015). Effects of saltwater intrusion in karstic wetlands extends ideas of traditional perturbation theory in that the perturbation factor (saltwater) contains two sub-factors (i.e., salinity and P) that, in theory, should cause opposite responses in ecosystem function. In our study, the direction of saltwater perturbation depended on the variable measured. Aboveground, elevated salinity had no effect on plant biomass or ecosystem C exchange, but higher $\mathrm{P}$ availability increased both. However, belowground, elevated salinity reduced live root biomass whereas higher $\mathrm{P}$ availability had no effect. These results show that although saltwater intrusion into karstic, freshwater wetlands may initially stimulate ecosystem productivity, peat soil stability may become compromised. Below, we further examine the effects and implications of saltwater intrusion into freshwater wetlands.

\section{Effects of salinity on plant biomass and C flux}

The effects of elevated salinity on soil $\mathrm{CO}_{2}$ and $\mathrm{CH}_{4}$ efflux from freshwater marsh ecosystems vary in magnitude, duration, and direction (Setia et al. 2010, Chambers et al. 2011, Weston et al. 2011, Marton et al. 2012). We found that elevated salinity reduced soil $\mathrm{CO}_{2}$ and soil $\mathrm{CH}_{4}$ efflux an average of $52 \%$ and $98 \%$, respectively (Table 3). Most saltwater manipulation studies on freshwater marsh soils to date have shown stimulatory

effects of elevated salinity on soil $\mathrm{CO}_{2}$ efflux (Weston et al. 2011, Marton et al. 2012). This response is usually attributed to an increase in $\mathrm{SO}_{4}{ }^{2-}$ availability, which adds an electron acceptor for microbial metabolism and stimulates sulfate reduction (Capone and 
Kiene 1988). However, we did not see this stimulatory effect. This could be because previous studies only examined low level salinity increases ( $\sim 5 \mathrm{ppt}$; Weston et al. 2011, Marton et al. 2012), although salinity in our study was slightly higher ( $\sim 9 \mathrm{ppt})$. Elevated salinity has been shown to cause osmotic stress for microbial communities and can even result in cell lysis (Wichern et al. 2006, Chambers et al. 2011). Given enough time, microbial communities adapted to higher salinities should replace those not adapted. In a similar mesocosm study, Wilson et al. (in review) found that raising salinity from 10 to $20 \mathrm{ppt}$ had no effect on soil $\mathrm{CO}_{2}$ efflux, but the mean overall flux was even lower $(0.20$ $0.24 \mu \mathrm{mol} \mathrm{CO}_{2} \mathrm{~m}^{-2} \mathrm{~s}^{-1}$ ) than fluxes measured at elevated salinity in the current study $\left(0.48-0.55 \mu \mathrm{mol} \mathrm{CO} \mathrm{CO}^{-2} \mathrm{~s}^{-1}\right)$. It is possible that as freshwater marshes transition to brackish conditions, organic matter inputs to the soil decrease, resulting in less substrate for microbial communities to use for respiration. Then, as salt-tolerant vegetation becomes established, organic matter inputs increase and concurrently, so does microbial respiration. Another possible factor contributing to lower soil $\mathrm{CO}_{2}$ efflux with elevated salinity is a reduction in root respiration, which can account for anywhere between 22 and $81 \%$ of overall soil respiration (Wang et al. 2006, Li et al. 2016). As freshwater vegetation becomes more stressed with elevated salinity, a reduction in root respiration is possible.

For many freshwater wetland plants, elevating salinity causes osmotic and ionic stress that can decrease aboveground biomass (Macek and Rejmankova 2007, Troxler et al. 2014), decrease root production (Charles et al. in prep), and shift the composition of species persistence in the marsh (Neubauer 2013). Although sawgrass is typically characterized as a freshwater wetland plant, it can persist under brackish water conditions 
(Wilson et al. 2015), extending into areas of the coastal Everglades with mean annual salinities up to $16.4 \mathrm{ppt}$ (Troxler et al. 2014). In our study, we found that elevated salinity $\sim 9$ ppt above ambient did not affect aboveground biomass after two years of continuous exposure (Fig. 3). However, Wilson et al. (in review) showed that elevating porewater salinity from 10 to $20 \mathrm{ppt}$ in a similar mesocosm experiment significantly decreased sawgrass GEP and ANPP. Therefore, there appears be a salinity "tipping point" between 10 to $20 \mathrm{ppt}$ in which sawgrass productivity is significantly affected. In a field survey within the estuarine ecotone of the Everglades, Troxler et al. (2014) found that the number of days in which surface water salinity exceeded $30 \mathrm{ppt}$ was significantly correlated with decreased sawgrass ANPP, but when the marsh was flushed with low salinity water $(<5 \mathrm{ppt})$, ANPP was unaffected by previous exposure to high salinity. The results of our study and others (Troxler et al. 2014) suggest that flushing by low salinity water is crucial for maintaining high productivity in sawgrass within the estuarine ecotone of the Everglades.

Although we found no decrease in GEP or ANPP with salinity elevated to $\sim 9 \mathrm{ppt}$, there was a significant decrease in live root biomass after two years of elevated salinity exposure, suggesting that elevated salinity is affecting belowground plant production. Elevated salinity in coastal wetlands has been shown to have a disproportionately larger effect on root rather than shoot growth (Rozema and Blom 1977, Janousek and Mayo 2013). Faster live-to-dead turnover of roots with added salinity likely created a new source of DOC (Hansson et al. 2010) and may explain why porewater DOC was much higher in the saltwater-amended monoliths than the freshwater monoliths. As roots die, DOC can be leached abiotically out of the soil and usually provides an additional energy 
source for bacteria (Pinney et al. 2000). However, we saw a decrease in soil $\mathrm{CO}_{2}$ efflux with increased salinity, which means that the microbial community was likely too stressed to use this newly available energy source (Schimel et al. 2007). In addition, we saw higher DOC content in the surface water, indicating that this newly produced DOC was interacting with the water column (Table S2). Therefore, saltwater intrusion has the potential to increase DOC export to downstream estuaries. This finding runs counter to other studies that show either no change or a decrease in porewater DOC and export with saltwater intrusion into freshwater wetlands (Weston et al. 2011, Ardon et al. 2016). Soil core experiments, like those performed in Weston et al. (2011) and Ardon et al. (2016), likely contain little to no live roots, and therefore an increase in DOC leaching from dying plant roots would not have been seen.

\section{Effects of $P$ on plant biomass and C flux}

In coastal wetlands, additional nutrient loading usually leads to an increase in soil respiration (Morris and Bradley 1999, Wigand et al. 2009). In the Everglades, $P$ is the main limiting nutrient (Noe et al. 2001). In the northern Everglades, P from fertilizer runoff has been shown to stimulate soil $\mathrm{CO}_{2}$ efflux by 36\% (Wright and Reddy 2007) and accelerate peat decomposition (Amador and Jones 1993, Qualls and Richardson 2008). We expected that an increase in P load would stimulate soil $\mathrm{CO}_{2}$ efflux; however, we found that adding $\mathrm{P}$ had no effect. The $\mathrm{P}$ loading rate in our experiment was low and only twice the ambient rate (King and Richardson 2008), potentially too low a dose to have a stimulatory effect on soil respiration. In nutrient-poor freshwater wetlands, such as the Everglades, high nutrient levels have also typically been correlated with higher $\mathrm{CH}_{4}$ 
production (Drake et al. 1996, Wright and Reddy 2001). We found that increased P loading stimulated soil $\mathrm{CH}_{4}$ by $96 \%$ in the freshwater monoliths, although because of high monthly variability, this effect was only marginally significant $(P=0.057)$. These results are similar to those by Holmes et al. (2014) who found a fourfold increase in soil $\mathrm{CH}_{4}$ efflux in a $\mathrm{P}$ enriched site compared to a nearby unenriched site. We may be underestimating the total $\mathrm{CH}_{4}$ flux from the marsh because we did not measure $\mathrm{CH}_{4}$ loss from the vegetation. Despite previous work suggesting that sawgrass does not have active gas transport through its aerenchyma (Chabbi et al. 2000), loss of $\mathrm{CH}_{4}$ through sawgrass stems has been measured in the Everglades and could account for a substantial portion of total $\mathrm{CH}_{4}$ efflux from the marsh (Steven Oberbauer, Florida International University, pers. comm.)

Inputs of limiting nutrient in oligotrophic wetlands can have both positive and negative effects in regard to marsh stability. Additions of limiting nutrients can stimulate both shoot and root production, increasing organic matter inputs into the soil (Macek and Rejmankova 2007). However, addition of nutrients may shift resource ratios and alter biomass allocation towards less root production, which in turn decreases organic input into the soil and could potentially leave it vulnerable to collapse (Tilman 1985, Castaneda-Moya et al. 2011, Deegan et al. 2012). We found that an increase in P loading significantly increased aboveground biomass, GEP, ER, and NEP (Table 3), but these results were not seen until the second year of $\mathrm{P}$ addition (Fig. 1, Fig. 2). In a similar study, Macek and Rejmankova (2007) found that P addition had no effect on sawgrass growth; however, their study lasted only 2 months. Sawgrass response to P enrichment is often slow, which is what typically allows cattails to outcompete sawgrass in the P- 
enriched northern Everglades (Lorenzen et al. 2001, Webb and Zhang 2013). We did not see an increase in macrophyte total P (TP) content after two years, which is consistent with results from a long-term $\mathrm{P}$ addition study in the Everglades that found that it took 34 years of continuous low-level $\mathrm{P}$ addition to see a change in macrophyte TP, although the dominant species in that study was Eleocharis cellulosa (Gaiser et al. 2005). Although not significant, live belowground root biomass after two years was higher in the P amended freshwater monoliths (Fig. 3), and root ingrowth doubled with P addition, regardless of the presence of salinity (Charles et al. in prep). However, added P shifted the shoot to root ratio towards more shoots and less roots in both the freshwater and saltwater monoliths, indicating a change in biomass allocation with the addition of P. Deegan et al. (2012) saw a similar shift in biomass allocation in a New England salt marsh with nutrient additions, a result they suggested caused increased erosion and collapse of the marsh. In addition to a shift in biomass allocation, we saw a reduction in soil bulk density with added $\mathrm{P}$, indicating that $\mathrm{P}$ additions alone could begin to destabilize the marsh.

\section{Saltwater intrusion: a subsidy or a stress?}

The exposure and duration of perturbations in coastal ecosystems can strongly influence the magnitude and direction of ecosystem functioning to a disturbance event and influence if the perturbation factor is a stress or a subsidy (Odum et al. 1979, Wright et al. 2015, Hanley et al. 2017). For example, wrack deposition in coastal marshes can be a strong stress to many ecosystem functions over the short term, but when viewed over a longer period, that stress affect can be alleviated by the additional delivery of nutrients 
that comes with deposition (Hanley et al. 2017). Here, we were able to determine the responses of some ecosystem functions to saltwater intrusion over both the short-term (monthly repeated measures) and long-term (2-year manipulation).

In our study, we found that the main forcing factor with saltwater intrusion (elevated salinity or increased P) was dependent on the variable measured. Net ecosystem productivity was greatly enhanced with added $\mathrm{P}$, mainly because of increased plant productivity, whereas elevated salinity had no effect on both NEP and ANPP. However, two years may not have been long enough to see the full effect of salinity on primary productivity. During the final months of measurements, NEP in the Salt $+\mathrm{P}$ treatment was significantly less than the Fresh + P treatment (Fig. 6c), potentially indicating that NEP had already plateaued and was trending downward because of continued salt stress as perturbation duration increased (Odum et al. 1979). Salt had a much stronger influence than $\mathrm{P}$ on both soil $\mathrm{CO}_{2}$ and $\mathrm{CH}_{4}$ efflux, which both decreased with elevated salinity (Table 3).

Although the response of NEP to $\mathrm{P}$ in the Salt $+\mathrm{P}$ treatment was greater than the response to salinity, it is important to examine how all responses to saltwater intrusion altered the greenhouse gas $\mathrm{C}$ balance. The contribution to greenhouse gas $\mathrm{C}$ balance accounts for not only the instantaneous uptake of $\mathrm{CO}_{2}$, but also the long-term radiative forcing of $\mathrm{CH}_{4}$ emitted to the atmosphere (Neubauer and Megonigal 2015). In our study, salinity strongly suppressed $\mathrm{CH}_{4}$ efflux, whereas increased $\mathrm{P}$ loading stimulated $\mathrm{CH}_{4}$ efflux, but only from the freshwater monoliths. Thus, saltwater intrusion, when coupled with increased P loading, had higher calculated NEP, and therefore a larger sink of $\mathrm{CO}_{2-}$ eq $\mathrm{C}$, than the freshwater control when accounting for the SGWP (Table 4). Although 
saltwater intrusion may initially increase the greenhouse gas $\mathrm{C}$ balance in a positive way, the overall health and survival of the marsh does not only depend on aboveground productivity (see below).

Saltwater intrusion into coastal wetlands is a current pressing issue because of the potential for elevated salinity to suppress ecosystem productivity in the short term. In non-tidal marshes without allochthonous sediment inputs, such as the Everglades, peat soils are formed primarily through organic matter inputs (Baustian et al. 2012). If saltwater disrupts the processes that form peat, peat may collapse. Although we found no decrease in GEP or ANPP with elevated salinity, there was a significant decrease in live root biomass. A decrease in live roots could result in less root binding of soil, causing the soils to begun to slump and collapse (Delaune et al. 1994). Another study conducted on the same mesocosm monoliths used in this study found that elevated salinity caused $\sim 2$ $\mathrm{cm}$ in elevation loss after only one year, whereas adding $\mathrm{P}$ had no effect (Charles et al. in prep). Therefore, even though aboveground productivity and NEP were unaffected by elevated salinity, soil structure and integrity appear to be negatively affected by salt and thus vulnerable to collapse. This finding would explain the presence of live sawgrass "pedestals" in the brackish portions of the Everglades (ambient salinity $10 \mathrm{ppt}$ ), where it appears that the surrounding soil has collapsed (Wilson et al. in review). Although saltwater intrusion into freshwater wetlands may initially stimulate primary productivity through a P subsidy, the impact of elevated salinity on root and soil structure may ultimately be what matters to the survival or collapse of these marshes. 


\section{ACKNOWLEDGEMENTS}

Funding for research was supported by National Science Foundation's Florida Coastal Everglades Long Term Ecological Research Program (DEB-1237517). Additional funding was provided through Florida Sea Grant R/C-S-56, including cooperative agreements with the Everglades Section of the South Florida Water Management District, the Everglades Foundation, and Everglades National Park. We are grateful to the State of Florida Department of Transportation Region 6 Office for working with us to gain permission to access and harvest peat for this experiment. We thank Laura Bauman, Rowan Johnson, Michael Kline, Michelle Robinson, and Ryan Stolee for help in the field. Thank you to Len Scinto for use of his GC for methane measurements. Steve Oberbauer provided valuable feedback on early drafts of this manuscript. Benjamin Wilson was supported by a Florida International University (FIU) Teaching Assistantship and FIU Dissertation Year Fellowship. This is contribution $\operatorname{xxxx}$ of the Southeast Environmental Research Center.

\section{LITERATURE CITED}

Amador, J. A., and R. D. Jones. 1993. Nutrient limitations on microbial respiration in peat soils with different total phosphorus content. Soil Biology \& Biochemistry 25:793-801.

Ardon, M., A. M. Helton, and E. S. Bernhardt. 2016. Drought and saltwater incursion synergistically reduce dissolved organic carbon export from coastal freshwater wetlands. Biogeochemistry 127:411-426.

Barr, J. G., V. Engel, T. J. Smith, and J. D. Fuentes. 2012. Hurricane disturbance and recovery of energy balance, $\mathrm{CO} 2$ fluxes and canopy structure in a mangrove forest of the Florida Everglades. Agricultural and Forest Meteorology 153:54-66. 
Baustian, J. J., I. A. Mendelssohn, and M. W. Hester. 2012. Vegetation's importance in regulating surface elevation in a coastal salt marsh facing elevated rates of sea level rise. Global Change Biology 18:3377-3382.

Bernal, B., J. P. Megonigal, and T. J. Mozdzer. 2017. An invasive wetland grass primes deep soil carbon pools. Global Change Biology 23:2104-2116.

Cahoon, D. R., P. Hensel, J. Rybczyk, K. L. McKee, C. E. Proffitt, and B. C. Perez. 2003. Mass tree mortality leads to mangrove peat collapse at Bay Islands, Honduras after Hurricane Mitch. Journal of Ecology 91:1093-1105.

Capone, D. G., and R. P. Kiene. 1988. Comparison of microbial dynamics in marine and fresh water sediments - contrasts in anaerobic carbon catabolism. Limnology and Oceanography 33:725-749.

Castaneda-Moya, E., R. R. Twilley, V. H. Rivera-Monroy, B. D. Marx, C. CoronadoMolina, and S. M. L. Ewe. 2011. Patterns of Root Dynamics in Mangrove Forests Along Environmental Gradients in the Florida Coastal Everglades, USA. Ecosystems 14:1178-1195.

Castaneda-Moya, E., R. R. Twilley, V. H. Rivera-Monroy, K. Q. Zhang, S. E. Davis, and M. Ross. 2010. Sediment and Nutrient Deposition Associated with Hurricane Wilma in Mangroves of the Florida Coastal Everglades. Estuaries and Coasts 33:45-58.

Chabbi, A., K. L. McKee, and I. A. Mendelssohn. 2000. Fate of oxygen losses from Typha domingensis (Typhaceae) and Cladium jamaicense (Cyperaceae) and consequences for root metabolism. American Journal of Botany 87:1081-1090.

Chambers, L. G., K. R. Reddy, and T. Z. Osborne. 2011. Short-Term Response of Carbon Cycling to Salinity Pulses in a Freshwater Wetland. Soil Science Society of America Journal 75:2000-2007.

Chiang, C., C. B. Craft, D. W. Rogers, and C. J. Richardson. 2000. Effects of 4 years of nitrogen and phosphorus additions on Everglades plant communities. Aquatic Botany 68:61-78.

Childers, D. L., D. Iwaniec, D. Rondeau, G. Rubio, E. Verdon, and C. J. Madden. 2006. Responses of sawgrass and spikerush to variation in hydrologic drivers and salinity in Southern Everglades marshes. Hydrobiologia 569:273-292.

Corstanje, R., K. R. Reddy, J. P. Prenger, S. Newman, and A. V. Ogram. 2007. Soil microbial eco-physiological response to nutrient enrichment in a sub-tropical wetland. Ecological Indicators 7:277-289. 
Danielson, T. M., V. H. Rivera-Monroy, E. Castaneda-Moya, H. Briceno, R. Travieso, B. D. Marx, E. Gaiser, and L. M. Farfan. 2017. Assessment of Everglades mangrove forest resilience: Implications for above-ground net primary productivity and carbon dynamics. Forest Ecology and Management 404:115-125.

Daoust, R. J., and D. L. Childers. 1998. Quantifying aboveground biomass and estimating net aboveground primary production for wetland macrophytes using a nondestructive phenometric technique. Aquatic Botany 62:115-133.

Daoust, R. J., and D. L. Childers. 2004. Ecological effects of low-level phosphorus additions on two plant communities in a neotropical freshwater wetland ecosystem. Oecologia 141:672-686.

DeBusk, W. F., and K. R. Reddy. 1998. Turnover of detrital organic carbon in a nutrientimpacted Everglades marsh. Soil Science Society of America Journal 62:14601468.

Deegan, L. A., D. S. Johnson, R. S. Warren, B. J. Peterson, J. W. Fleeger, S. Fagherazzi, and W. M. Wollheim. 2012. Coastal eutrophication as a driver of salt marsh loss. Nature 490:388-+.

Delaune, R. D., J. A. Nyman, and W. H. Patrick. 1994. Peat collapse, ponding and wetland loss in a rapidly submerging coastal marsh. Journal of Coastal Research 10:1021-1030.

Delaune, R. D., S. R. Pezeshki, and W. H. Patrick. 1987. Response of coastal plants to increase in submergence and salinity. Journal of Coastal Research 3:535-546.

Drake, H. L., N. G. Aumen, C. Kuhner, C. Wagner, A. Griesshammer, and M. Schmittroth. 1996. Anaerobic microflora of everglades sediments: Effects of nutrients on population profiles and activities. Applied and Environmental Microbiology 62:486-493.

Faulkner, S. P., W. H. Patrick, and R. P. Gambrell. 1989. Field techniques for measuring wetland soil parameters. Soil Science Society of America Journal 53:883-890.

Flower, H., M. Rains, D. Lewis, J. Z. Zhang, and R. Price. 2017. Saltwater intrusion as potential driver of phosphorus release from limestone bedrock in a coastal aquifer. Estuarine Coastal and Shelf Science 184:166-176.

Gaiser, E. E., J. C. Trexler, J. H. Richards, D. L. Childers, D. Lee, A. L. Edwards, L. J. Scinto, K. Jayachandran, G. B. Noe, and R. D. Jones. 2005. Cascading ecological effects of low-level phosphorus enrichment in the Florida everglades. Journal of Environmental Quality 34:717-723. 
Hanley, T. C., D. L. Kimbro, and A. R. Hughes. 2017. Stress and subsidy effects of seagrass wrack duration, frequency, and magnitude on salt marsh community structure. Ecology 98:1884-1895.

Hansson, K., D. B. Kleja, K. Kalbitz, and H. Larsson. 2010. Amounts of carbon mineralised and leached as DOC during decomposition of Norway spruce needles and fine roots. Soil Biology \& Biochemistry 42:178-185.

Herbert, E. R., P. Boon, A. J. Burgin, S. C. Neubauer, R. B. Franklin, M. Ardon, K. N. Hopfensperger, L. P. M. Lamers, and P. Gell. 2015. A global perspective on wetland salinization: ecological consequences of a growing threat to freshwater wetlands. Ecosphere 6.

Holmes, M. E., J. P. Chanton, H. S. Bae, and A. Ogram. 2014. Effect of nutrient enrichment on delta(CH4)-C-13 and the methane production pathway in the Florida Everglades. Journal of Geophysical Research-Biogeosciences 119:12671280 .

Janousek, C. N., and C. Mayo. 2013. Plant responses to increased inundation and salt exposure: interactive effects on tidal marsh productivity. Plant Ecology 214:917928.

King, R. S., and C. J. Richardson. 2008. Macroinvertebrate and Fish Responses to Experimental P Additions in Everglades Sloughs. Everglades Experiments: Lessons for Ecosystem Restoration. Springer, New York.

Lenth, R.V. 2017. Using lsmeans. https://cran.rproject.org/web/packages/lsmeans/vignettes/using-lsmeans.pdf

Lorenzen, B., H. Brix, I. A. Mendelssohn, K. L. McKee, and S. L. Miao. 2001. Growth, biomass allocation and nutrient use efficiency in Cladium jamaicense and Typha domingensis as affected by phosphorus and oxygen availability. Aquatic Botany 70:117-133.

Macek, P., and E. Rejmankova. 2007. Response of emergent macrophytes to experimental nutrient and salinity additions. Functional Ecology 21:478-488.

Marton, J. M., E. R. Herbert, and C. B. Craft. 2012. Effects of Salinity on Denitrification and Greenhouse Gas Production from Laboratory-incubated Tidal Forest Soils. Wetlands 32:347-357.

Medvedeff, C. A., K. S. Inglett, and P. W. Inglett. 2015. Patterns and controls of anaerobic soil respiration and methanogenesis following extreme restoration of calcareous subtropical wetlands. Geoderma 245:74-82. 
Mitsch, W. J., and J. G. Gosselink. 2007. Wetlands. 4th ed. edition. John Wiley \& Sons, Inc., Hoboken, NJ.

Morris, J. T., and P. M. Bradley. 1999. Effects of nutrient loading on the carbon balance of coastal wetland sediments. Limnology and Oceanography 44:699-702.

Munns, R., and M. Tester. 2008. Mechanisms of salinity tolerance. Annual Review of Plant Biology 59:651-681.

Nahlik, A. M., and M. S. Fennessy. 2016. Carbon storage in US wetlands. Nature Communications 7.

Neubauer, S. C. 2013. Ecosystem responses of a tidal freshwater marsh experiencing saltwater intrusion and altered hydrology. Estuaries and Coasts 36:491-507.

Neubauer, S. C., and J. P. Megonigal. 2015. Moving Beyond Global Warming Potentials to Quantify the Climatic Role of Ecosystems. Ecosystems 18:1000-1013.

Noe, G. B., D. L. Childers, A. L. Edwards, E. Gaiser, K. Jayachandran, D. Lee, J. Meeder, J. Richards, L. J. Scinto, J. C. Trexler, and R. D. Jones. 2002. Short-term changes in phosphorus storage in an oligotrophic Everglades wetland ecosystem receiving experimental nutrient enrichment. Biogeochemistry 59:239-267.

Noe, G. B., D. L. Childers, and R. D. Jones. 2001. Phosphorus biogeochemistry and the impact of phosphorus enrichment: Why is the everglades so unique? Ecosystems 4:603-624.

Odum, E. P., J. T. Finn, and E. H. Franz. 1979. Perturbation-Theory and the SubsidyStress Gradient. Bioscience 29:349-352.

Odum, W. E., E. P. Odum, and H. T. Odum. 1995. Nature's pulsing paradigm. Estuaries 18:547-555.

Paerl, H. W. 2006. Assessing and managing nutrient-enhanced eutrophication in estuarine and coastal waters: Interactive effects of human and climatic perturbations. Ecological Engineering 26:40-54.

Pearlstine, L. G., E. V. Pearlstine, and N. G. Aumen. 2010. A review of the ecological consequences and management implications of climate change for the Everglades. Journal of the North American Benthological Society 29:1510-1526.

Pinney, M. L., P. K. Westerhoff, and L. Baker. 2000. Transformations in dissolved organic carbon through constructed wetlands. Water Research 34:1897-1911. 
Poff, N. L. 2002. Ecological response to and management of increased flooding caused by climate change. Philosophical Transactions of the Royal Society of London Series a-Mathematical Physical and Engineering Sciences 360:1497-1510.

Poorter, H., and O. Nagel. 2000. The role of biomass allocation in the growth response of plants to different levels of light, $\mathrm{CO} 2$, nutrients and water: a quantitative review. Australian Journal of Plant Physiology 27:595-607.

Price, R. M., P. K. Swart, and J. W. Fourqurean. 2006. Coastal groundwater discharge an additional source of phosphorus for the oligotrophic wetlands of the Everglades. Hydrobiologia 569:23-36.

Qualls, R. G., and C. J. Richardson. 2008. Carbon cycling and dissolved organic matter export in the northern Everglades.in C. J. Richardson, editor. The Everglades Experiments, Ecological Studies. Springer, New York.

Rejmankova, E., and P. Macek. 2008. Response of root and sediment phosphatase activity to increased nutrients and salinity. Biogeochemistry 90:159-169.

Rozema, J., and B. Blom. 1977. Effects of Salinity and Inundation on the Growth of Agrostis Stolonifera and Juncus Gerardii. Journal of Ecology 65:213-222.

Schimel, J., T. C. Balser, and M. Wallenstein. 2007. Microbial stress-response physiology and its implications for ecosystem function. Ecology 88:1386-1394.

Setia, R., P. Marschner, J. Baldock, and D. Chittleborough. 2010. Is CO2 evolution in saline soils affected by an osmotic effect and calcium carbonate? Biology and Fertility of Soils 46:781-792.

Sharpe, P. J., and A. H. Baldwin. 2012. Tidal marsh plant community response to sealevel rise: A mesocosm study. Aquatic Botany 101:34-40.

Shea, K., S. H. Roxburgh, and E. S. J. Rauschert. 2004. Moving from pattern to process: coexistence mechanisms under intermediate disturbance regimes. Ecology Letters 7:491-508.

Smith, C. J., R. D. Delaune, and W. H. Patrick. 1983. Carbon-dioxide emission and carbon accumulation in coastal wetlands. Estuarine Coastal and Shelf Science 17:21-29.

Smith, T. J., G. H. Anderson, K. Balentine, G. Tiling, G. A. Ward, and K. R. T. Whelan. 2009. Cumulative impacts of hurricanes on Florida mangrove ecosystems: sediment deposition, storm surges and vegetation. Wetlands 29:24-34. 
Solorzano, L., and J. H. Sharp. 1980. Determination of total dissolved phosphorus and particulate phosphorus in natural-waters. Limnology and Oceanography 25:754757.

Spalding, E. A., and M. W. Hester. 2007. Interactive effects of hydrology and salinity on oligohaline plant species productivity: Implications of relative sea-level rise. Estuaries and Coasts 30:214-225.

Tilman, D. 1985. The resource-ratio hypothesis of plant succession. American Naturalist 125:827-852.

Troxler, T. G., D. L. Childers, and C. J. Madden. 2014. Drivers of Decadal-Scale Change in Southern Everglades Wetland Macrophyte Communities of the Coastal Ecotone. Wetlands 34:S81-S90.

Wanless, H. R., and B. M. Vlaswinkel. 2005. Coastal landscape and channel evolution affecting critical habitats at Cape Sable, Everglades National Park, Florida.

Webb, J., and X. H. Zhang. 2013. Organ-disparate allocation of plasticity in phosphorus response as an underlying mechanism for the sawgrass-to-cattail habitat shift in Florida Everglades wetlands. International Journal of Plant Sciences 174:779-790.

Webster, K. L., J. W. McLaughlin, Y. Kim, M. S. Packalen, and C. S. Li. 2013. Modelling carbon dynamics and response to environmental change along a boreal fen nutrient gradient. Ecological Modelling 248:148-164.

Weston, N. B., M. A. Vile, S. C. Neubauer, and D. J. Velinsky. 2011. Accelerated microbial organic matter mineralization following salt-water intrusion into tidal freshwater marsh soils. Biogeochemistry 102:135-151.

Wichern, J., F. Wichern, and R. G. Joergensen. 2006. Impact of salinity on soil microbial communities and the decomposition of maize in acidic soils. Geoderma 137:100108.

Wigand, C., P. Brennan, M. Stolt, M. Holt, and S. Ryba. 2009. Soil respiration rates in coastal marshes subject to increasing watershed nitrogen loads in southern New England, USA. Wetlands 29:952-963.

Wilson, B. J., B. Mortazavi, and R. P. Kiene. 2015. Spatial and temporal variability in carbon dioxide and methane exchange at three coastal marshes along a salinity gradient in a northern Gulf of Mexico estuary. Biogeochemistry 123:329-347.

Wright, A. J., A. Ebeling, H. de Kroon, C. Roscher, A. Weigelt, N. Buchmann, T. Buchmann, C. Fischer, N. Hacker, A. Hildebrandt, S. Leimer, L. Mommer, Y. Oelmann, S. Scheu, K. Steinauer, T. Strecker, W. Weisser, W. Wilcke, and N. 
Eisenhauer. 2015. Flooding disturbances increase resource availability and productivity but reduce stability in diverse plant communities. Nature Communications 6.

Wright, A. L., and K. R. Reddy. 2001. Heterotrophic microbial activity in northern Everglades wetland soils. Soil Science Society of America Journal 65:1856-1864.

Wright, A. L., and K. R. Reddy. 2007. Substrate-induced respiration for phosphorusenriched and oligotrophic peat soils in an Everglades wetland. Soil Science Society of America Journal 71:1579-1583.

Zhang, K. Q., M. Simard, M. Ross, V. H. Rivera-Monroy, P. Houle, P. Ruiz, R. R. Twilley, and K. R. T. Whelan. 2008. Airborne laser scanning quantification of disturbances from hurricanes and lightning strikes to mangrove forests in Everglades National Park, USA. Sensors 8:2262-2292.

Zimmermann, C. F., and C. W. Keefe. 1997. Method 440.0. Determination of carbon and nitrogen in sediments and particulates of estuarine/coastal waters using elemental analysis. U.S. Environmental Protection Agency, National Exposure Research Laboratory, Office of Research and Development, Cincinnati, Ohio. 


\section{TABLES}

Table 1. Porewater temperature, salinity, $\mathrm{pH}$, and dissolved constituents.

\begin{tabular}{lrrccccccc}
\hline Treatment & $\begin{array}{r}\text { Temp } \\
\left({ }^{\circ} \mathbf{C}\right)\end{array}$ & $\begin{array}{r}\text { Salinity } \\
(\mathbf{p p t})\end{array}$ & $\mathbf{p H}$ & $\mathbf{D O C}$ & NO $_{2}^{-}$ & NO $^{-}$ & NH $^{+}$ & SRP $^{-}$ \\
Fresh & $26.1 \pm 0.3$ & $0.44 \pm 0.01^{\mathrm{a}}$ & $6.81 \pm 0.01^{\mathrm{a}}$ & $1862 \pm 83^{\mathrm{a}}$ & $0.11 \pm 0.006^{\mathrm{a}}$ & $0.46 \pm 0.08$ & $6.60 \pm 0.77^{\mathrm{a}}$ & $0.15 \pm 0.03^{\mathrm{a}}$ & $0.010 \pm 0.001^{\mathrm{a}}$ \\
\hline Fresh $+\mathbf{P}$ & $26.6 \pm 0.3$ & $0.47 \pm 0.01^{\mathrm{a}}$ & $6.80 \pm 0.01^{\mathrm{a}}$ & $1981 \pm 92^{\mathrm{a}}$ & $0.12 \pm 0.011^{\mathrm{a}}$ & $0.58 \pm 0.14$ & $8.80 \pm 2.05^{\mathrm{a}}$ & $0.20 \pm 0.06^{\mathrm{a}}$ & $0.007 \pm 0.001^{\mathrm{a}}$ \\
\hline Salt & $26.8 \pm 0.3$ & $9.03 \pm 0.28^{\mathrm{b}}$ & $6.71 \pm 0.01^{\mathrm{b}}$ & $3281 \pm 132^{\mathrm{b}}$ & $0.27 \pm 0.022^{\mathrm{b}}$ & $0.32 \pm 0.06$ & $36.55 \pm 4.01^{\mathrm{b}}$ & $0.38 \pm 0.03^{\mathrm{b}}$ & $0.270 \pm 0.023^{\mathrm{b}}$ \\
\hline Salt+P & $27.1 \pm 0.4$ & $8.63 \pm 0.26^{\mathrm{b}}$ & $6.70 \pm 0.02^{\mathrm{b}}$ & $3268 \pm 106^{\mathrm{b}}$ & $0.25 \pm 0.013^{\mathrm{b}}$ & $0.27 \pm 0.03$ & $28.60 \pm 3.45^{\mathrm{b}}$ & $0.39 \pm 0.02^{\mathrm{b}}$ & $0.209 \pm 0.019^{\mathrm{b}}$
\end{tabular}

Data represent mean ( $n=6$ replicates $) \pm 1$ standard error of temperature, salinity, $\mathrm{pH}$, and dissolved porewater constituents averaged across treatments. DOC, $\mathrm{NO}_{2}{ }^{-}, \mathrm{NO}_{3}{ }^{-}, \mathrm{NH}_{4}{ }^{+}$, and SRP are in $\mu \mathrm{mol} \mathrm{L}{ }^{-1}, \mathrm{HS}^{-}$is in mM. Letters represent significant differences among treatments from a multiple comparison test (LSMEANS, Tukey adjusted).

$\mathrm{DOC}$ dissolved organic carbon, $\mathrm{NO}_{2}^{-}$nitrate, $\mathrm{NO}_{3}^{-}$nitrite, $\mathrm{NH}_{4}^{+}$ammonium, $\mathrm{SRP}$ soluble reactive phosphorus, $\mathrm{HS}^{-}$sulfide. 
Table 2. Full statistical results for the linear mixed model.

\begin{tabular}{|c|c|c|c|c|c|c|c|}
\hline & Salinity & $\mathbf{P}$ & Time & Salinity*P & Salinity*Time & P*Time & Salinity*P*Time \\
\hline Temperature & $\begin{array}{l}F(1,20)=60.5 \\
P<0.001\end{array}$ & $\begin{array}{l}F(1,20)=34.0 \\
P<0.001\end{array}$ & $\begin{array}{l}F(24,476)=906.7 \\
P<0.001\end{array}$ & $\begin{array}{l}F(1,20)=0.3 \\
P=0.591\end{array}$ & $\begin{array}{l}F(24,476)=6.7 \\
P<0.001\end{array}$ & $\begin{array}{l}F(24,476)=13.8 \\
P<0.001\end{array}$ & $\begin{array}{l}F(24,476)=2.1 \\
P=0.002\end{array}$ \\
\hline pH & $\begin{array}{l}F(1,20)=19.4 \\
P<0.001\end{array}$ & $\begin{array}{l}F(1,20)=0.0 \\
P=0.860\end{array}$ & $\begin{array}{l}F(23,456)=28.2 \\
P<0.001\end{array}$ & $\begin{array}{l}F(1,20)=0.0 \\
P=0.941\end{array}$ & $\begin{array}{l}F(23,456)=9.8 \\
P<0.001\end{array}$ & $\begin{array}{l}F(23,456)=3.3 \\
P<0.001\end{array}$ & $\begin{array}{l}F(23,456)=2.1 \\
P=0.017\end{array}$ \\
\hline DOC & $\begin{array}{l}F(1,20)=85.88 \\
P<0.001\end{array}$ & $\begin{array}{l}F(1,20)=0.12 \\
P=0.729\end{array}$ & $\begin{array}{l}F(24,477)=45.32 \\
P<0.001\end{array}$ & $\begin{array}{l}F(1,20)=0.18 \\
P=0.669\end{array}$ & $\begin{array}{l}F(24,477)=8.55 \\
P<0.001\end{array}$ & $\begin{array}{l}F(24,477)=2.14 \\
P=0.001\end{array}$ & $\begin{array}{l}F(24,477)=1.41 \\
P=0.094\end{array}$ \\
\hline $\mathrm{NH}_{4}^{+}$ & $\begin{array}{l}F(1,20)=26.43 \\
P<0.001\end{array}$ & $\begin{array}{l}F(1,20)=0.34 \\
P=0.561\end{array}$ & $\begin{array}{l}F(24,477)=17.57 \\
P<0.001\end{array}$ & $\begin{array}{l}F(1,20)=1.23 \\
P=0.278\end{array}$ & $\begin{array}{l}F(24,477)=13.6 \\
P<0.001\end{array}$ & $\begin{array}{l}F(24,477)=0.71 \\
P=0.840\end{array}$ & $\begin{array}{l}F(24,477)=0.59 \\
P=0.937\end{array}$ \\
\hline $\mathrm{NO}_{2}^{-}$ & $\begin{array}{l}F(1,20)=56.42 \\
P<0.001\end{array}$ & $\begin{array}{l}F(1,20)=0.39 \\
P=0.538\end{array}$ & $\begin{array}{l}F(24,470)=15.27 \\
P<0.001\end{array}$ & $\begin{array}{l}F(1,20)=0.04 \\
P=0.826\end{array}$ & $\begin{array}{l}F(24,470)=8.22 \\
P<0.001\end{array}$ & $\begin{array}{l}F(24,470)=1.83 \\
P=0.009\end{array}$ & $\begin{array}{l}F(24,470)=1.07 \\
P=0.372\end{array}$ \\
\hline $\mathrm{NO}_{3}^{-}$ & $\begin{array}{l}F(1,20)=3.11 \\
P=0.092\end{array}$ & $\begin{array}{l}F(1,20)=0.79 \\
P=0.384\end{array}$ & $\begin{array}{l}F(22,375)=11.99 \\
P<0.001\end{array}$ & $\begin{array}{l}F(1,20)=0.00 \\
P=0.934\end{array}$ & $\begin{array}{l}F(22,375)=4.74 \\
P<0.001\end{array}$ & $\begin{array}{l}F(22,375)=0.66 \\
P=0.874\end{array}$ & $\begin{array}{l}F(22,375)=1.07 \\
P=0.373\end{array}$ \\
\hline SRP & $\begin{array}{l}F(1,20)=31.70 \\
P<0.001\end{array}$ & $\begin{array}{l}F(1,20)=0.01 \\
P=0.900\end{array}$ & $\begin{array}{l}F(24,442)=12.48 \\
P<0.001\end{array}$ & $\begin{array}{l}F(1,20)=0.06 \\
P=0.801\end{array}$ & $\begin{array}{l}F(24,442)=11.4 \\
P<0.001\end{array}$ & $\begin{array}{l}F(24,442)=1.87 \\
P=0.007\end{array}$ & $\begin{array}{l}F(24,442)=1.23 \\
P=0.205\end{array}$ \\
\hline Sulfide & $\begin{array}{l}F(1,20)=44.75 \\
P<0.001\end{array}$ & $\begin{array}{l}F(1,20)=0.86 \\
P=0.362\end{array}$ & $\begin{array}{l}F(15,273)=12.48 \\
P<0.001\end{array}$ & $\begin{array}{l}F(1,20)=0.84 \\
P=0.370\end{array}$ & $\begin{array}{l}F(15,273)=6.02 \\
P<0.001\end{array}$ & $\begin{array}{l}F(15,273)=1.73 \\
P=0.045\end{array}$ & $\begin{array}{l}F(15,273)=1.85 \\
P=0.027\end{array}$ \\
\hline Soil $\mathrm{CO}_{2}$ & $\begin{array}{l}F(1,20)=44.92 \\
P<0.001\end{array}$ & $\begin{array}{l}F(1,20)=1.83 \\
P=0.190\end{array}$ & $\begin{array}{l}F(12,238)=7.16 \\
P<0.001\end{array}$ & $\begin{array}{l}F(1,20)=4.38 \\
P=0.049\end{array}$ & $\begin{array}{l}F(12,238)=3.68 \\
P<0.001\end{array}$ & $\begin{array}{l}F(12,238)=1.13 \\
P=0.334\end{array}$ & $\begin{array}{l}F(12,238)=1.29 \\
P=0.221\end{array}$ \\
\hline Soil $\mathrm{CH}_{4}$ & $\begin{array}{l}F(1,12)=8.32 \\
P=0.013\end{array}$ & $\begin{array}{l}F(1,12)=4.41 \\
P=0.057\end{array}$ & $\begin{array}{l}F(6,72)=3.70 \\
P=0.002\end{array}$ & $\begin{array}{l}F(1,12)=1.43 \\
P=0.254\end{array}$ & $\begin{array}{l}F(6,72)=4.12 \\
P=0.001\end{array}$ & $\begin{array}{l}F(6,72)=0.61 \\
P=0.718\end{array}$ & $\begin{array}{l}F(6,72)=0.41 \\
P=0.867\end{array}$ \\
\hline GEP & $\begin{array}{l}F(1,12)=2.54 \\
P=0.136\end{array}$ & $\begin{array}{l}F(1,12)=68.24 \\
P<0.001\end{array}$ & $\begin{array}{l}F(6,72)=46.51 \\
P<0.001\end{array}$ & $\begin{array}{l}F(1,12)=6.09 \\
P=0.029\end{array}$ & $\begin{array}{l}F(6,72)=1.61 \\
P=0.154\end{array}$ & $\begin{array}{l}F(6,72)=17.23 \\
P<0.001\end{array}$ & $\begin{array}{l}F(6,72)=5.14 \\
P<0.001\end{array}$ \\
\hline $\mathbf{E R}_{\mathrm{CO} 2}$ & $\begin{array}{l}F(1,12)=0.63 \\
P=0.439\end{array}$ & $\begin{array}{l}F(1,12)=17.36 \\
P=0.001\end{array}$ & $\begin{array}{l}F(6,72)=31.75 \\
P<0.001\end{array}$ & $\begin{array}{l}F(1,12)=0.41 \\
P=0.531\end{array}$ & $\begin{array}{l}F(6,72)=2.15 \\
P=0.053\end{array}$ & $\begin{array}{l}F(6,72)=5.57 \\
P<0.001\end{array}$ & $\begin{array}{l}F(6,72)=2.48 \\
P=0.030\end{array}$ \\
\hline NEP & $\begin{array}{l}F(1,12)=4.06 \\
P=0.066\end{array}$ & $\begin{array}{l}F(1,12)=95.66 \\
P<0.001\end{array}$ & $\begin{array}{l}F(7,84)=36.66 \\
P<0.001\end{array}$ & $\begin{array}{l}F(1,12)=10.14 \\
P=0.007\end{array}$ & $\begin{array}{l}F(7,84)=0.91 \\
P=0.499\end{array}$ & $\begin{array}{l}F(7,84)=14.59 \\
P<0.001\end{array}$ & $\begin{array}{l}F(7,84)=3.97 \\
P<0.001\end{array}$ \\
\hline Biomass & $\begin{array}{l}F(1,20)=2.01 \\
P=0.171\end{array}$ & $\begin{array}{l}F(1,20)=8.54 \\
P=0.008\end{array}$ & $\begin{array}{l}F(10,200)=11.04 \\
P<0.001\end{array}$ & $\begin{array}{l}F(1,20)=0.92 \\
P=0.348\end{array}$ & $\begin{array}{l}F(10,200)=1.02 \\
P=0.420\end{array}$ & $\begin{array}{l}F(10,200)=7.45 \\
P<0.001\end{array}$ & $\begin{array}{l}F(10,200)=1.42 \\
P=0.169\end{array}$ \\
\hline ANPP & $\begin{array}{l}F(1,20)=0.69 \\
P=0.413\end{array}$ & $\begin{array}{l}F(1,20)=11.46 \\
P=0.002\end{array}$ & $\begin{array}{l}F(9,180)=1.66 \\
P=0.099\end{array}$ & $\begin{array}{l}F(1,20)=1.68 \\
P=0.208\end{array}$ & $\begin{array}{l}F(9,180)=1.07 \\
P=0.379\end{array}$ & $\begin{array}{l}F(9,180)=3.25 \\
P=0.001\end{array}$ & $\begin{array}{l}F(9,180)=0.54 \\
P=0.838\end{array}$ \\
\hline Redox & $\begin{array}{l}F(1,20)=10.12 \\
P=0.004\end{array}$ & $\begin{array}{l}F(1,20)=3.22 \\
P=0.087\end{array}$ & $\begin{array}{l}F(10,728)=62.27 \\
P<0.001\end{array}$ & $\begin{array}{l}F(1,20)=1.37 \\
P=0.254\end{array}$ & $\begin{array}{l}F(10,728)=3.91 \\
P<0.001\end{array}$ & $\begin{array}{l}F(10,728)=0.53 \\
P=0.865\end{array}$ & $\begin{array}{l}F(10,728)=0.75 \\
P=0.673\end{array}$ \\
\hline
\end{tabular}


Model run with time as an independent variable for temperature, salinity, $\mathrm{pH}$, dissolved porewater constituents, ecosystem C flux, biomass, and redox. Interpreted results are in bold. Data presented as $F$ (numerator degrees of freedom,denominator degrees of freedom) $=F$ value, $P=P$ value. DOC, TOC, $\mathrm{NO}_{2}, \mathrm{NO}_{3}{ }^{-}, \mathrm{NH}_{4}{ }^{+}$, and SRP are in $\mu \mathrm{mol} \mathrm{L}^{-1}$. Interpreted results are in bold.

$D O C$ dissolved organic carbon, $\mathrm{NH}_{4}^{+}$ammonium, $T D N$ total dissolved nitrogen, $\mathrm{SO}_{4}^{2-}$ sulfate, $T D P$ total dissolved phosphorus, $S R P$ soluble reactive phosphorus, $G E P$ gross ecosystem productivity, $E R_{C O 2}$ ecosystem respiration of $\mathrm{CO}_{2}, N E P$ net ecosystem productivity, $A N P P$ aboveground net primary productivity. 
Table 3. Averaged carbon flux measured over the experimental period.

\begin{tabular}{lrrrrr}
\hline Treatment & NEP & GEP & ER $_{\text {CO2 }}$ & Soil CO & Soil CH $_{4}$ \\
\hline Fresh & $5.3 \pm 0.5^{\mathrm{a}}$ & $6.6 \pm 0.5^{\mathrm{a}}$ & $1.4 \pm 0.2^{\mathrm{a}}$ & $0.93 \pm 0.08^{\mathrm{a}}$ & $9.3 \pm 5.0^{\mathrm{ab}}$ \\
\hline Fresh+P & $12.5 \pm 2.1^{\mathrm{b}}$ & $15.8 \pm 2.9^{\mathrm{b}}$ & $3.2 \pm 0.7^{\mathrm{b}}$ & $1.23 \pm 0.12^{\mathrm{a}}$ & $35.2 \pm 12.9^{\mathrm{a}}$ \\
\hline Salt & $6.0 \pm 0.8^{\mathrm{a}}$ & $7.4 \pm 1.1^{\mathrm{a}}$ & $1.4 \pm 0.3^{\mathrm{a}}$ & $0.55 \pm 0.07^{\mathrm{b}}$ & $-0.01 \pm 0.77^{\mathrm{b}}$ \\
\hline Salt+P & $9.6 \pm 1.3^{\mathrm{b}}$ & $12.3 \pm 1.7^{\mathrm{b}}$ & $2.7 \pm 0.5^{\mathrm{ab}}$ & $0.48 \pm 0.07^{\mathrm{b}}$ & $1.4 \pm 0.6^{\mathrm{ab}}$ \\
\hline
\end{tabular}

Data represent the mean $(n=4$ or 6$) \pm 1$ SE of net ecosystem productivity (NEP), gross ecosystem productivity (GEP), ecosystem respiration of $\mathrm{CO}_{2}\left(\mathrm{ER}_{\mathrm{CO} 2}\right)$, soil $\mathrm{CO}_{2}$ (all in $\mu \mathrm{mol} \mathrm{CO} \mathrm{C}^{-2} \mathrm{~s}^{-1}$ ), and soil $\mathrm{CH}_{4}$ flux $\left(\mathrm{nmol} \mathrm{CH}_{4} \mathrm{~m}^{-2} \mathrm{~s}^{-1}\right)$ from each treatment over the duration of the experiment. Letters represent significant differences among treatments from a multiple comparison test (LSMEANS, Tukey adjusted). 
Table 4. Calculated sustained-flux global warming potential (SGWP) over a 100-year period and corrected net ecosystem productivity (NEP) accounting for the contribution of methane $\left(\mathrm{CH}_{4}\right)$ to the global greenhouse carbon balance.

\begin{tabular}{lrrrrr}
\hline & $\mathbf{C H}_{\mathbf{4}}$ & SGWP & NEP & $\begin{array}{r}\text { Corrected } \\
\text { NEP }\end{array}$ & $\begin{array}{r}\mathbf{C H}_{\mathbf{4}}: \\
\mathbf{C O}_{\mathbf{2}}\end{array}$ \\
\hline Fresh & $0.024 \pm 0.013$ & $1.11 \pm 0.59$ & $3.81 \pm 0.39$ & $2.70 \pm 0.49$ & 0.291 \\
\hline Fresh $+\mathbf{P}$ & $0.092 \pm 0.034$ & $4.18 \pm 1.53$ & $8.99 \pm 1.53$ & $4.80 \pm 1.53$ & 0.466 \\
\hline Salt & $0.000 \pm 0.000$ & $-0.00 \pm 0.10$ & $4.28 \pm 0.54$ & $4.28 \pm 0.32$ & -0.001 \\
\hline Salt+P & $0.003 \pm 0.001$ & $0.16 \pm 0.07$ & $6.91 \pm 0.95$ & $6.74 \pm 0.51$ & 0.024 \\
\hline
\end{tabular}

All units are in $\mathrm{mg} \mathrm{C} \mathrm{m}^{-2} \mathrm{~min}^{-1}$. SGWP is calculated as 45 times the measured soil $\mathrm{CH}_{4}$ flux when $\mathrm{CH}_{4}$ was emitted, and as 203 times soil $\mathrm{CH}_{4}$ flux when there was uptake (Salt) (Neubauer and Megonigal 2015). Corrected NEP is calculated as the difference between NEP and SGWP. 


\section{FIGURES}

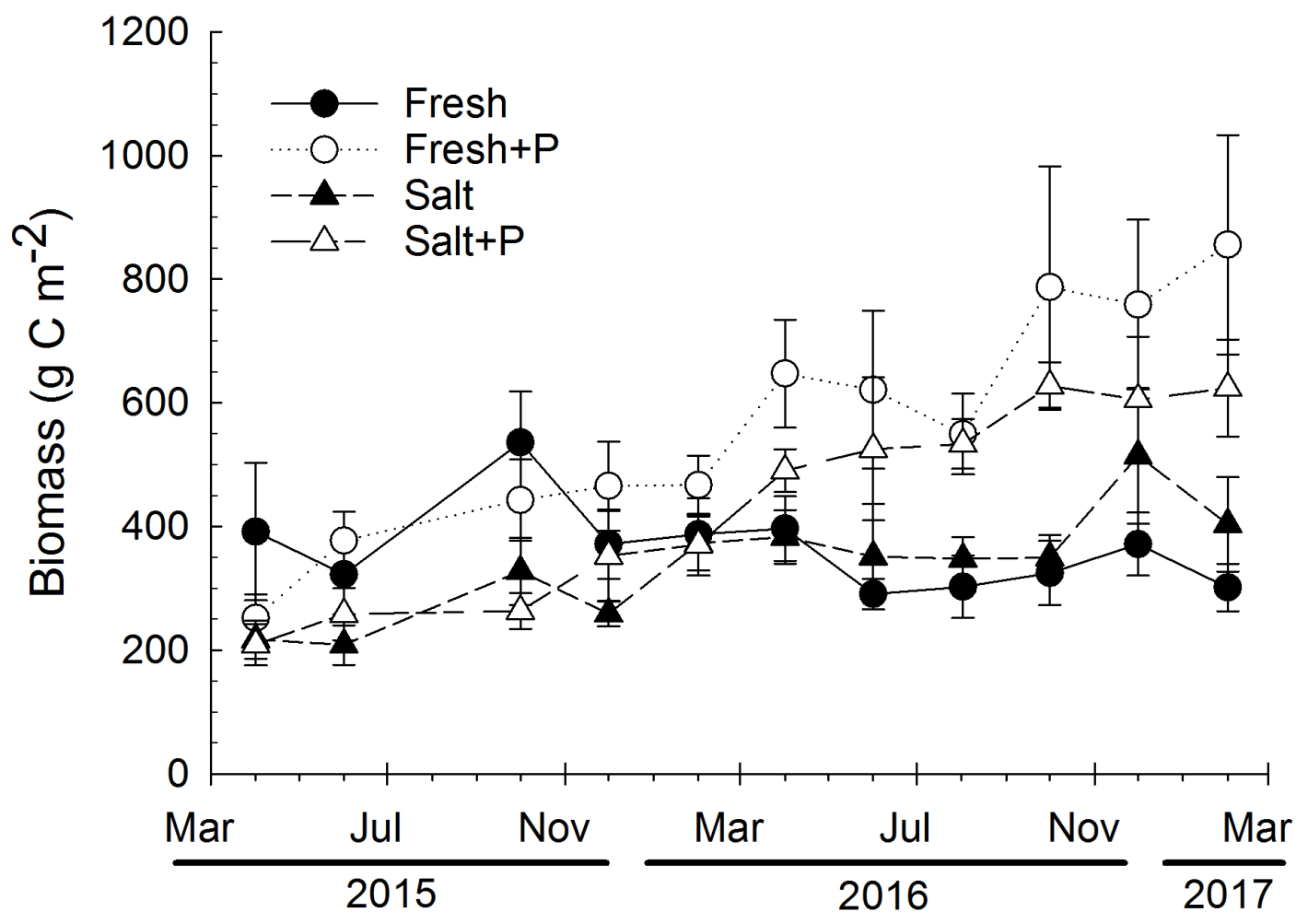

Figure 1. Change in sawgrass aboveground live biomass over time for each treatment. Points represent the monthly mean $(n=6$ replicates per treatment $) \pm 1 \mathrm{SE}$. 


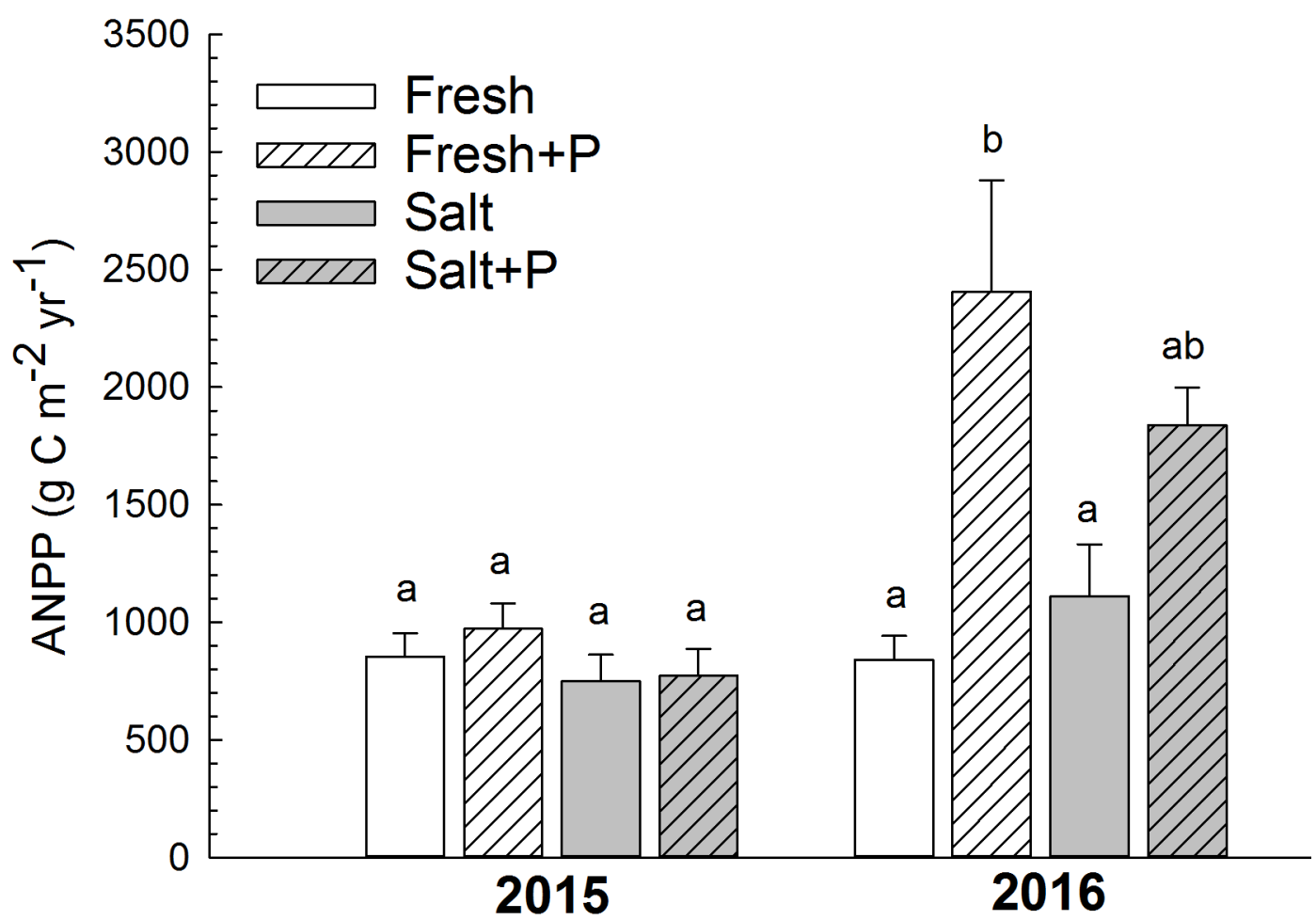

Figure 2. Measured aboveground net primary productivity (ANPP) separated by treatment and year. Letters represent the results of a Tukey's post-hoc analysis performed separately for each year. Points represent the annual mean ( $n=6$ replicates per treatment) $\pm 1 \mathrm{SE}$. 


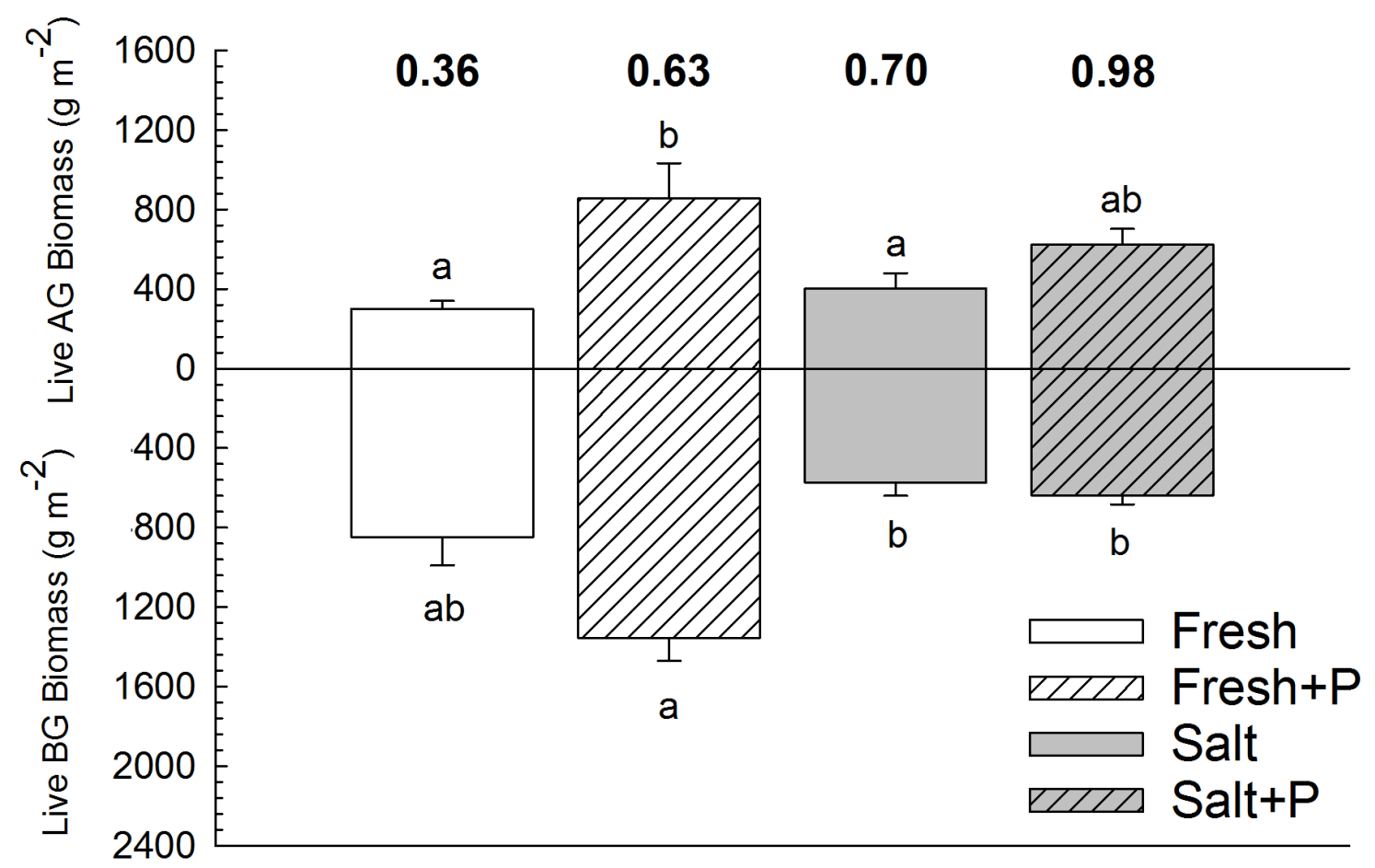

Figure 3. Live aboveground (AG) and belowground (BG) biomass at the end of the experiment. Aboveground biomass was calculated allometrically, whereas belowground biomass was measured through soil coring down to 30-cm depth. Subscripted letters represent differences among treatments from a Tukey's HSD post-hoc test. Bars represent the mean $(n=6$ replicates per treatment $) \pm 1 \mathrm{SE}$ in grams dry weight of material per meter squared. The number at the top of each treatment represents the ratio of aboveground to belowground biomass. 


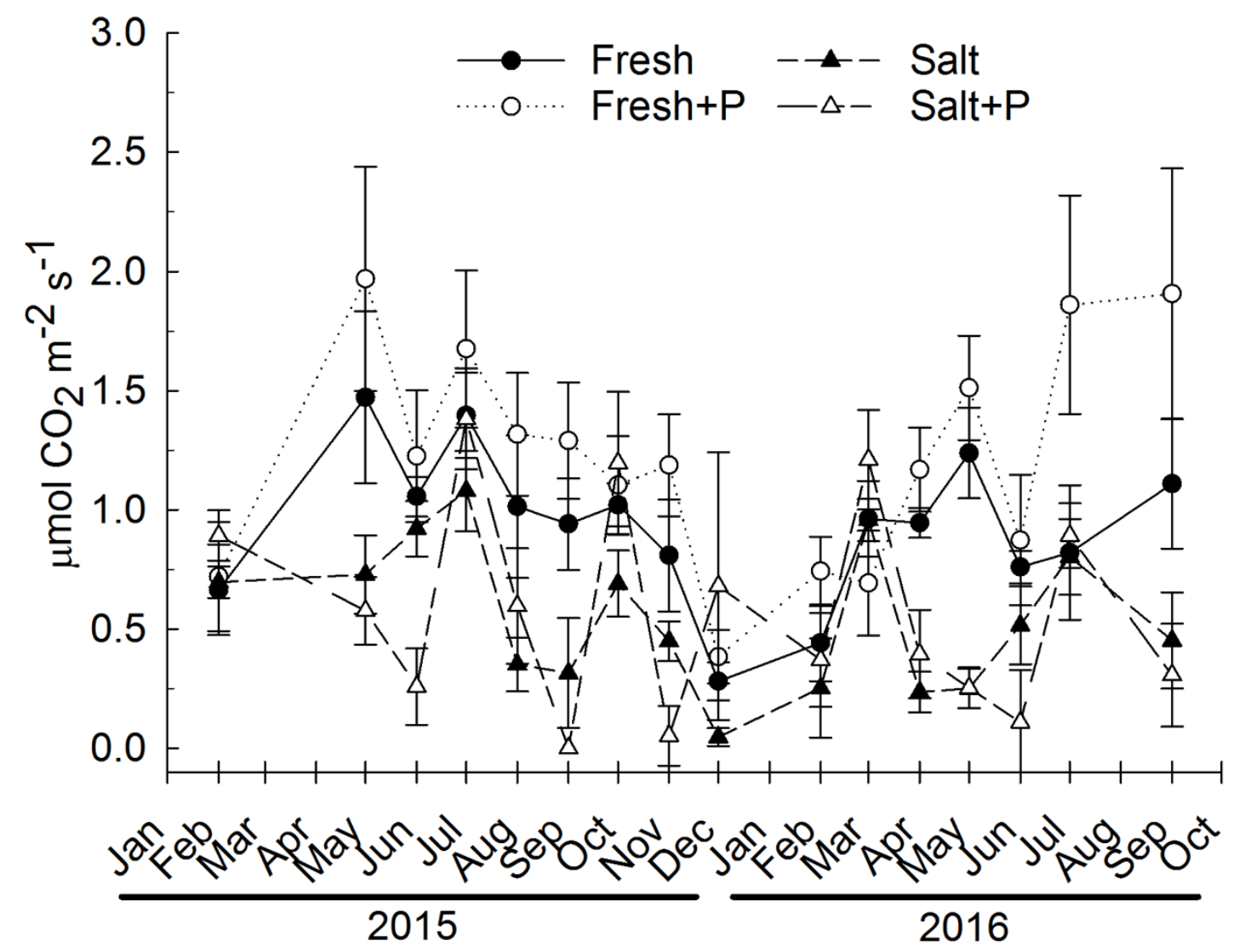

Figure 4. Monthly soil $\mathrm{CO}_{2}$ efflux over time for each treatment. Points represent the monthly mean $(n=6$ replicates per treatment $) \pm 1$ SE. 


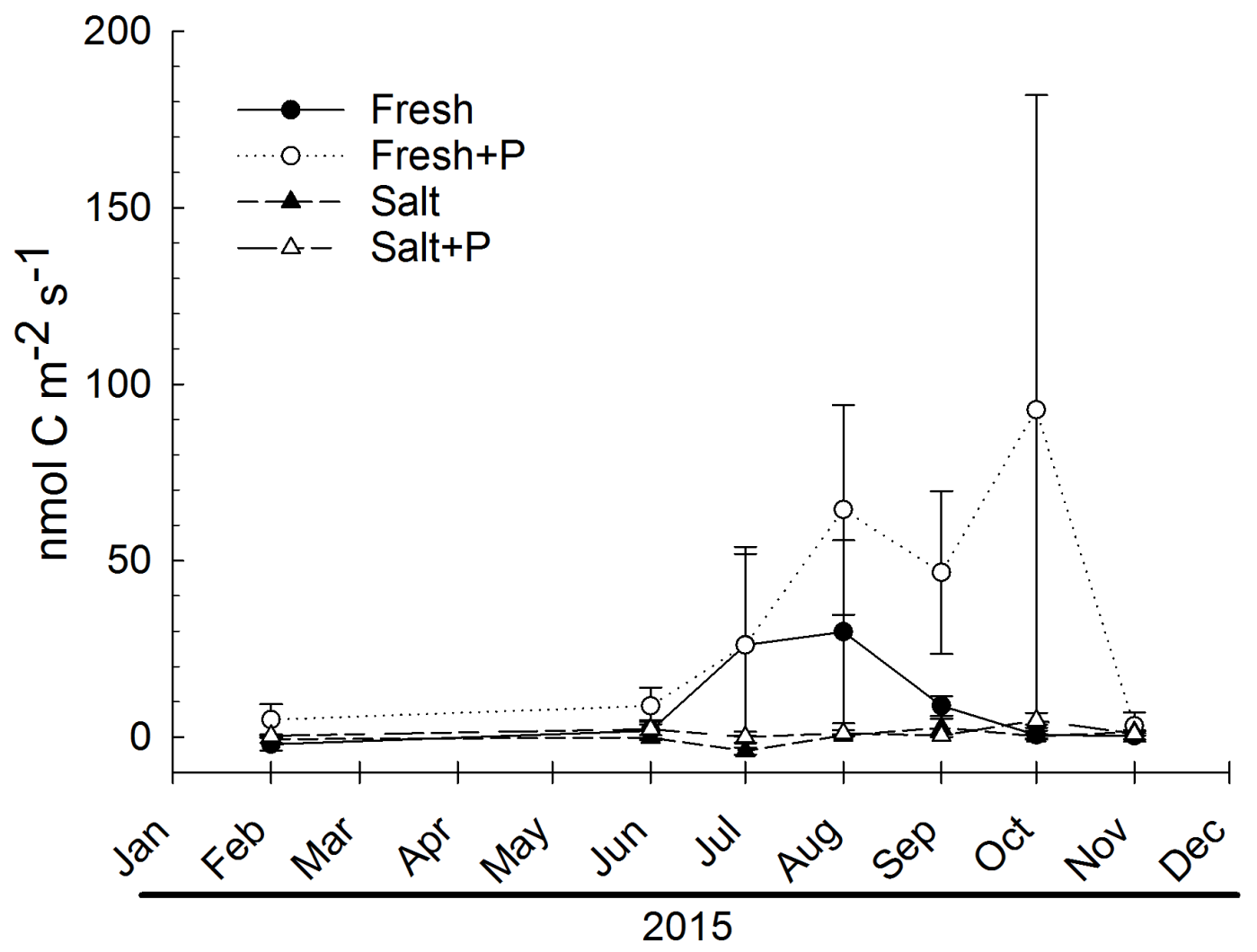

Figure 5. Measured soil methane $\left(\mathrm{CH}_{4}\right)$ efflux over the first year of the experiment. Points represent the monthly mean $(n=4$ replicates per treatment $) \pm 1$ SE. 

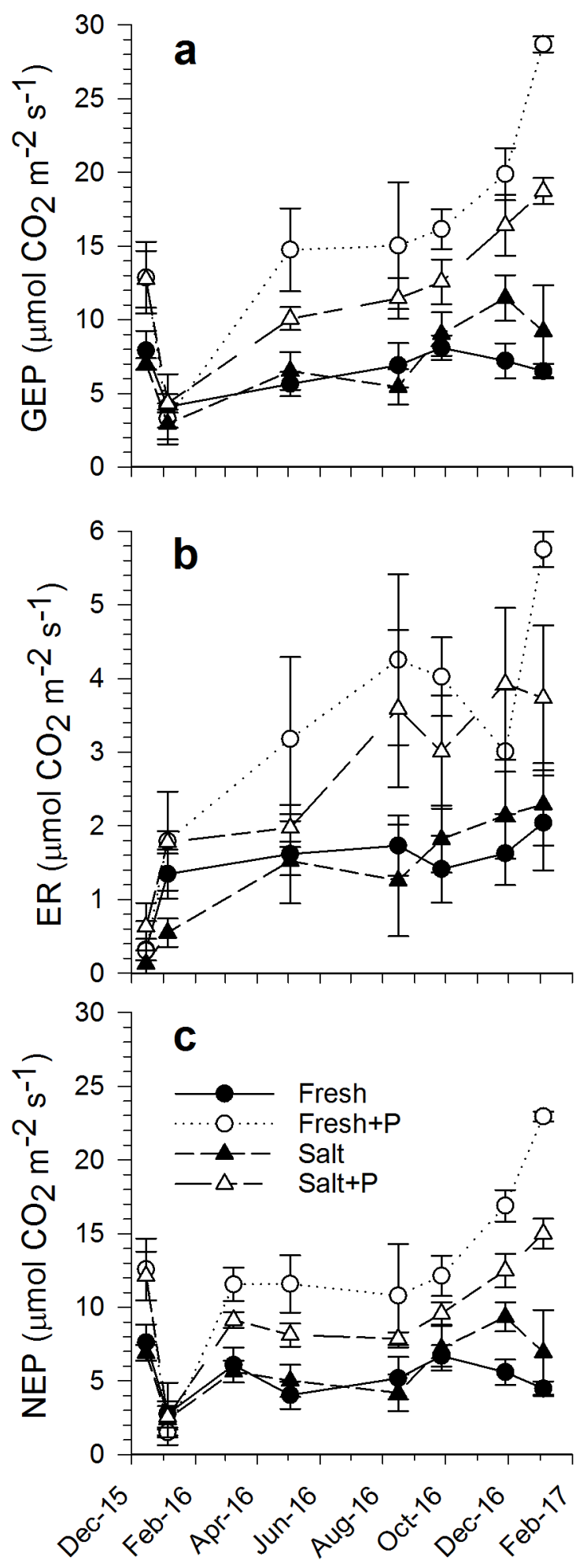

Figure 6. Instantaneous flux of gross ecosystem productivity (a; GEP), ecosystem respiration of $\mathrm{CO}_{2}$ (b; ER), and net ecosystem productivity (c; NEP). Points represent the monthly mean $(n=4$ replicates per treatment $) \pm 1 \mathrm{SE}$. 


\section{SUPPLEMENTAL INFORMATION}

Table S1. Source water temperature, salinity, $\mathrm{pH}$, and dissolved constituents added to monoliths designated either "Fresh $(+\mathrm{P})$ " or "Salt $(+\mathrm{P})$ ". Data represent mean $(n=6$ replicates) \pm 1 standard error of temperature, salinity, $\mathrm{pH}$, and dissolved constituents. $\mathrm{NO}_{2}^{-}, \mathrm{NO}_{3}^{-}, \mathrm{NH}_{4}{ }^{+}, \mathrm{SRP}$, and DOC are in $\mu \mathrm{mol} \mathrm{L}{ }^{-1}$. Means were calculated from 1/6/2016 to $12 / 11 / 2016$ for the freshwater samples and from $1 / 6 / 2016$ to $5 / 21 / 2016$ for the saltwater samples. Fresh source water was added to the "Salt $(+\mathrm{P})$ " monoliths starting in June of 2016 to prevent salinity treatment monoliths from becoming hypersaline through evaporation. Fresh and Salt source waters were compared using an independent t-test and * indicates $P<0.05$.

$\mathrm{NO}_{2}{ }^{-}$nitrate, $\mathrm{NO}_{3}{ }^{-}$nitrite, $\mathrm{NH}_{4}{ }^{+}$ammonium, $\mathrm{SRP}$ soluble reactive phosphorus, $\mathrm{DOC}$ dissolved organic carbon

\begin{tabular}{llll}
\hline & Fresh & Salt & $\boldsymbol{P}$ \\
\hline salinity & $0.25 \pm 0.03$ & $4.62 \pm 0.19$ & $*$ \\
\hline $\mathbf{p H}$ & $7.72 \pm 0.25$ & $7.77 \pm 0.12$ & \\
\hline $\mathbf{N O}_{3}{ }^{-}$ & $0.65 \pm 0.16$ & $1.56 \pm 0.54$ & \\
\hline $\mathbf{N O}_{2}{ }^{-}$ & $0.11 \pm 0.05$ & $0.28 \pm 0.13$ & \\
$\mathbf{N H}_{4}{ }^{+}$ & $4.14 \pm 1.39$ & $1.21 \pm 0.41$ & \\
\hline SRP & $0.05 \pm 0.01$ & $0.15 \pm 0.05$ & \\
\hline DOC & $532.1 \pm 73.8$ & $360.8 \pm 48.6$ & \\
\hline
\end{tabular}


Table S2. Surface water temperature, salinity, $\mathrm{pH}$, and dissolved constituents. Data represent mean $(n=6$ replicates $) \pm 1$ standard error of temperature, salinity, $\mathrm{pH}$, and dissolved porewater constituents averaged across treatments. $\mathrm{DOC}, \mathrm{TOC}^{-\mathrm{NO}_{2}}{ }^{-}, \mathrm{NO}_{3}^{-}$,

$\mathrm{NH}_{4}^{+}, \mathrm{TN}, \mathrm{SRP}$, and TP are in $\mu \mathrm{mol} \mathrm{L}{ }^{-1}$. Letters represent a significant difference in means among treatments from a two-way ANOVA followed by a Tukey's post-hoc test.

$D O C$ dissolved organic carbon, $T O C$ total organic carbon, $\mathrm{NO}_{2}{ }^{-}$nitrate, $\mathrm{NO}_{3}{ }^{-}$nitrite, $\mathrm{NH}_{4}{ }^{+}$ammonium, $\mathrm{TN}$ total nitrogen, $\mathrm{SRP}$ soluble reactive phosphorus, $T P$ total phosphorus

\begin{tabular}{lrrccccc} 
Treatment & $\begin{array}{r}\text { Temp } \\
\left({ }^{\circ} \mathbf{C}\right)\end{array}$ & $\begin{array}{r}\text { Salinity } \\
(\mathbf{p p t})\end{array}$ & $\mathbf{p H}$ & $\mathbf{D O C}$ & TOC & NO $^{-}$ & NO $^{-}$ \\
\hline Fresh & $25.1 \pm 0.2$ & $0.46 \pm 0.01^{\mathrm{a}}$ & $7.10 \pm 0.02^{\mathrm{ab}}$ & $1481 \pm 59^{\mathrm{a}}$ & $1504 \pm 51^{\mathrm{a}}$ & $0.13 \pm 0.01^{\mathrm{a}}$ & $0.28 \pm 0.05$ \\
\hline Fresh $+\mathbf{P}$ & $24.5 \pm 0.3$ & $0.44 \pm 0.01^{\mathrm{a}}$ & $7.11 \pm 0.01^{\mathrm{a}}$ & $1367 \pm 52^{\mathrm{a}}$ & $1421 \pm 59^{\mathrm{a}}$ & $0.13 \pm 0.01^{\mathrm{a}}$ & $0.36 \pm 0.07$ \\
\hline Salt & $24.9 \pm 0.3$ & $8.35 \pm 0.31^{\mathrm{b}}$ & $7.02 \pm 0.02^{\mathrm{ab}}$ & $1863 \pm 87^{\mathrm{b}}$ & $2080 \pm 85^{\mathrm{b}}$ & $0.20 \pm 0.01^{\mathrm{b}}$ & $0.37 \pm 0.06$ \\
\hline Salt+P & $25.2 \pm 0.3$ & $8.08 \pm 0.29^{\mathrm{b}}$ & $7.01 \pm 0.02^{\mathrm{b}}$ & $2062 \pm 76^{\mathrm{b}}$ & $2279 \pm 81^{\mathrm{b}}$ & $0.24 \pm 0.02^{\mathrm{b}}$ & $0.25 \pm 0.03$ \\
\hline
\end{tabular}

\begin{tabular}{lrrrr}
\hline Treatment & $\mathbf{N H}_{\mathbf{4}}{ }^{+}$ & $\mathbf{T N}$ & $\mathbf{S R P}$ & $\mathbf{T P}$ \\
\hline Fresh & $2.55 \pm 0.36^{\mathrm{ab}}$ & $60.7 \pm 2.3^{\mathrm{a}}$ & $0.12 \pm 0.01^{\mathrm{a}}$ & $0.55 \pm 0.03^{\mathrm{a}}$ \\
\hline Fresh $+\mathbf{P}$ & $2.28 \pm 0.16^{\mathrm{a}}$ & $59.4 \pm 2.2^{\mathrm{a}}$ & $0.41 \pm 0.09^{\mathrm{a}}$ & $1.05 \pm 0.05^{\mathrm{a}}$ \\
\hline Salt & $5.01 \pm 0.99^{\mathrm{b}}$ & $104.3 \pm 4.4^{\mathrm{b}}$ & $0.29 \pm 0.03^{\mathrm{a}}$ & $0.89 \pm 0.07^{\mathrm{a}}$ \\
\hline Salt $+\mathbf{P}$ & $4.07 \pm 0.56^{\mathrm{ab}}$ & $131.9 \pm 5.5^{\mathrm{b}}$ & $0.62 \pm 0.07^{\mathrm{b}}$ & $2.25 \pm 0.15^{\mathrm{b}}$ \\
\hline
\end{tabular}


Table S3. Sawgrass leaf carbon $(\mathrm{C})$, nitrogen $(\mathrm{N})$, and phosphorus $(\mathrm{P})$ concentrations and molar ratios $(\mathrm{C}: \mathrm{N}: \mathrm{P})$ collected after 1 and 2 years of experimental manipulation.

\begin{tabular}{llrrrr}
\hline Treatment & Time & $\mathbf{C}\left(\mathbf{m g ~ g}^{-\mathbf{1}}\right)$ & $\mathbf{N}\left(\mathbf{m g ~ g}^{-\mathbf{1}}\right)$ & $\mathbf{P}\left(\boldsymbol{\mu g ~ \mathbf { ~ g } ^ { - 1 } )}\right.$ & $\mathbf{C : N : P}$ \\
\hline Fresh & Year 1 & $462 \pm 3.9$ & $6.51 \pm 0.22$ & $190.9 \pm 15.3^{\mathrm{a}}$ & $2420: 34: 1$ \\
\hline Fresh+P & & $464 \pm 1.2$ & $6.39 \pm 0.25$ & $232.5 \pm 14.0^{\mathrm{ab}}$ & $1995: 28: 1$ \\
\hline Salt & & $456 \pm 1.4$ & $7.25 \pm 0.23$ & $282.8 \pm 15.7^{\mathrm{ab}}$ & $1612: 26: 1$ \\
\hline Salt+P & & $460 \pm 2.2$ & $7.46 \pm 0.33$ & $290.1 \pm 16.3^{\mathrm{b}}$ & $1585: 26: 1$ \\
\hline Fresh & Year 2 & $489 \pm 2.2$ & $6.29 \pm 0.38$ & $210.7 \pm 7.4$ & $2321: 30: 1$ \\
\hline Fresh+P & & $495 \pm 4.2$ & $5.85 \pm 0.36$ & $300.2 \pm 16.3$ & $1648: 20: 1$ \\
\hline Salt & & $495 \pm 5.0$ & $6.73 \pm 0.77$ & $276.1 \pm 18.8$ & $1792: 24: 1$ \\
\hline Salt+P & & $503 \pm 4.3$ & $6.75 \pm 0.57$ & $289.4 \pm 13.3$ & $1738: 23: 1$ \\
\hline
\end{tabular}

Data represent mean $(n=6) \pm 1$ standard error of C, N, and P sawgrass leaf content for each year. Subscripted letters represent results from a Tukey's HSD test performed separately for each parameter and year. If no letters are present, there were no significant differences between treatments for that parameter and year. 


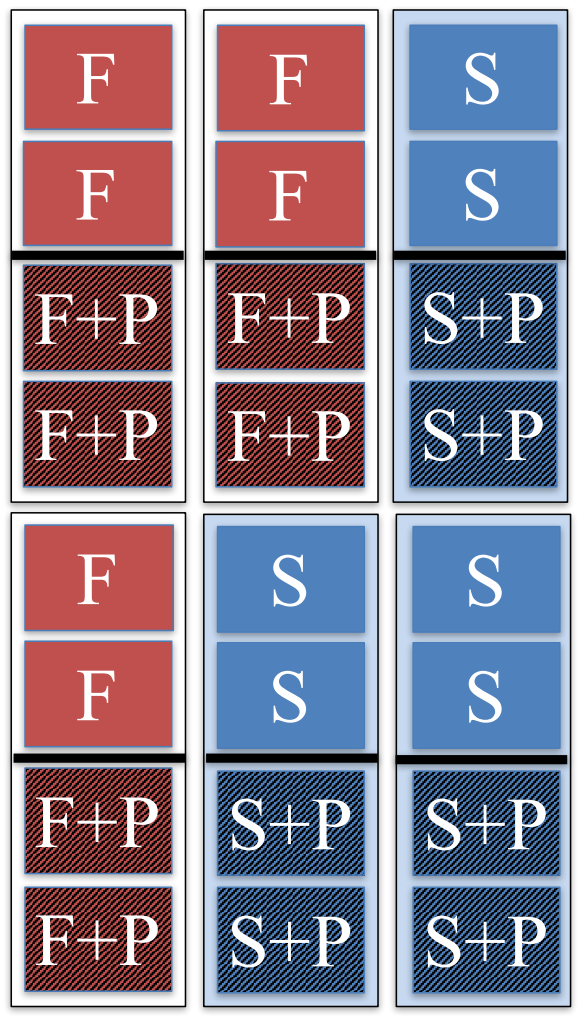

Figure S1. Experimental design of the mesocosm experiment containing the Fresh $(\mathrm{F})$, Fresh $+\mathrm{P}(\mathrm{F}+\mathrm{P})$, Salt $(\mathrm{S})$, and Salt $+\mathrm{P}(\mathrm{S}+\mathrm{P})$ treatments. Each monolith was housed within its own individual container within one of six tanks. Each tank contained four monoliths, two receiving $\mathrm{P}$ additions and two not receiving any additional P. Even though there was no interaction between each monolith within each tank, a divider was placed between the $\mathrm{P}$ addition and no $\mathrm{P}$ addition monoliths to prevent any contamination from splashing caused by rainfall (black bar). 
CHAPTER III

DECLINES IN PLANT PRODUCTIVITY DRIVE CARBON LOSS FROM COASTAL WETLAND ECOSYSTEMS EXPOSED TO SALTWATER INTRUSION AND SEA-

LEVEL RISE 
Declines in plant productivity drive carbon loss from coastal wetland ecosystems exposed to saltwater intrusion and sea-level rise

Running head: Saltwater intrusion and ecosystem C cycling

Benjamin J. Wilson ${ }^{1}$, Shelby Servais ${ }^{1}$, Sean P. Charles ${ }^{1}$, Stephen E. Davis ${ }^{2}$, Evelyn E. Gaiser $^{1}$, John S. Kominoski ${ }^{1}$, Jennifer H. Richards ${ }^{1}$, and Tiffany G. Troxler ${ }^{1}$

${ }^{1}$ Department of Biological Sciences, Florida International University, Miami, FL 33199, USA

${ }^{2}$ Everglades Foundation, Palmetto Bay, FL 33157, USA

Corresponding author: Benjamin J. Wilson

Phone: 2059138397 Email: bwils034@fiu.edu

Keywords: Cladium jamaicense, Florida Everglades, biogeochemistry, salinity, marsh, peat collapse.

Type of paper: Primary Research article 


\begin{abstract}
Coastal wetlands are among the most productive ecosystems and important reservoirs of carbon (C) on Earth. Accelerated sea level rise (SLR) and saltwater intrusion in coastal wetlands increase salinity and inundation depth with uncertain effects on plant and soil processes that drive $\mathrm{C}$ storage. To differentiate soil from plant responses, we exposed peat soil monoliths with and without sawgrass (Cladium jamaicense) plants from a brackish marsh to continuous treatments of salinity [elevated $(\sim 20 \mathrm{ppt})$ vs. ambient $(\sim 10$ ppt)] and inundation levels [submerged vs. exposed (water level 4-cm below soil surface)] for 18 months. We quantified changes in soil biogeochemistry, plant productivity, and whole-ecosystem $\mathrm{C}$ flux. We hypothesized that increased inundation depth and salinity would decrease plant productivity and ecosystem respiration (ER). Initial exposure to elevated salinity (within 1 week) increased $\mathrm{CO}_{2}$ efflux from soils without sawgrass, but elevated salinity had no effect on soil $\mathrm{CO}_{2}$ efflux from plant-soil monoliths. Elevated salinity had no effect on soil $\mathrm{CH}_{4}$ efflux, decreased ER by $42 \%$ and decreased gross ecosystem productivity by $72 \%$. Control monoliths exposed to ambient salinity had greater net ecosystem productivity (NEP), storing up to 9 times more $\mathrm{C}$ than plants and soils exposed to elevated salinity. Increased inundation had no effect on NEP. Decreased plant productivity and soil organic C inputs with saltwater intrusion are likely mechanisms of net declines in soil $\mathrm{C}$ storage, which may affect the ability of coastal peat marshes to adapt to rising seas. These results provide experimental evidence for plantmediated mechanisms for "peat collapse", a phenomenon observed in the Everglades and other coastal wetland ecosystems.
\end{abstract}




\section{INTRODUCTION}

Coastal wetland ecosystems are important global carbon (C) sinks that are directly threatened by climate change (Kirwan and Megonigal, 2013). With average global sea level rising $\sim 3 \mathrm{~mm} \mathrm{yr}^{-1}$ (Ryan and Law, 2005), and recent increases up to $9 \mathrm{~mm} \mathrm{yr}^{-1}$ in some coastal areas (Wdowinski et al., 2016), saltwater intrusion in low-lying freshwater and brackish coastal wetlands will increase, potentially altering ecosystem $\mathrm{C}$ dynamics through effects on plants and soils (Valentine, 2002; Whalen, 2005). Reduced freshwater delivery to some coastal wetlands and increased soil erosion through reduced sediment delivery in others can further exacerbate the impacts of SLR and saltwater intrusion on coastal wetlands (Herbert et al., 2015). As C storage is linked to the provision of many ecosystem services, including $\mathrm{CO}_{2}$ sequestration, recreational and commercial fisheries, water quality, wildlife habitat, and storm surge protection (Engle, 2011; McLeod et al., 2011), understanding how saltwater intrusion alters $C$ storage in coastal ecosystems is crucial for predicting how these vital services will be affected.

Carbon storage in coastal wetlands is controlled by complex interactions between allochthonous water and material supplies, water residence time and depth, physical soil processes, and the metabolic balance of plant production and organic matter mineralization by soil microbes (Morris et al., 2002; Neubauer, 2013; Weston et al., 2006). In wetland soils, increased salinity and water depth associated with SLR can change geochemical and biological processes, resulting in altered $\mathrm{C}$ storage capacity (Herbert et al., 2015). Elevated salinity and duration of salinity exposure can create osmotic stress to microbial communities by suppressing cellular respiration or even lysing cells (Chambers et al., 2011; Wichern et al., 2006). Conversely, exposure to some 
ionic constituents of saltwater, particularly sulfate $\left(\mathrm{SO}_{4}{ }^{2-}\right)$, can increase overall $\mathrm{CO}_{2}$ efflux from soils through increased sulfate reduction as salinity increases (Chambers et al., 2011; Weston et al., 2011). Unlike sulfate reduction, elevated salinity usually results in decreased rates of methanogenesis through sulfate-reducing bacteria outcompeting methanogens, given the higher energy yield of sulfate reduction (Capone and Kiene, 1988; Poffenbarger et al., 2011; Weston et al., 2006). Yet low-level saltwater addition has also been shown to stimulate $\mathrm{CH}_{4}$ production from freshwater marsh soils (Weston et al., 2011), and large $\mathrm{CH}_{4}$ stocks have been found in saline environments (Wilson et al., 2015). Elevated salinity can produce plant morphological and physiological changes (Larcher, 2003; Rejmankova and Macek, 2008) that affect photosynthetic efficiencies, growth, maintenance, and nutrient uptake (Neubauer, 2013; Pezeshki et al., 1987a; Pezeshki et al., 1987b). Because microbial respiration and plant productivity strongly mediate $\mathrm{CO}_{2}$ and $\mathrm{CH}_{4}$ exchange in wetlands, understanding short- and long-term responses to saltwater exposure and increased water depth is critical to understanding soil C storage.

In addition to increasing salinity, SLR can also increase water depth, flood duration, and residence time. In many coastal wetlands influenced by tidal and riverine sediment inputs, increased water depth equates to higher inorganic sedimentation rates and, therefore, higher accretion rates up to a threshold (Morris et al., 2002). In coastal mangrove and marsh ecosystems that receive little sediment input, however, root production has been identified as the primary driver of vertical peat accretion and soil C accumulation (Baustian et al., 2012; McKee, 2011; Nyman et al., 2006). Higher water levels create a diffusive barrier that prevents oxygen and other gases from entering the 
soil, affecting plant productivity (Jackson and Colmer, 2005), and suppressing aerobic respiration and overall organic $\mathrm{C}$ mineralization, which leads to a reduction in overall soil $\mathrm{CO}_{2}$ efflux to the atmosphere (Neubauer et al., 2000). Longer water residence time leads to a predominance of anaerobic respiratory pathways, typically allowing methanogens to thrive where sulfate concentrations are low (i.e., low salinity; Poffenbarger et al., 2011), leading to increases in $\mathrm{CH}_{4}$ efflux (Morse et al., 2012). Increased flooding depth has been shown to decrease plant productivity (Wichern et al., 2006) and gross ecosystem productivity (GEP; Whalen, 2005), usually as a result of decreased leaf area available for gas exchange (Schedlbauer et al., 2010), oxygen stress of roots, and increased production of phytotoxins (Rejmankova and Macek, 2008). However, a resulting decrease in ecosystem respiration (ER) can be greater than the effect on GEP, resulting in increased net ecosystem productivity (NEP; Whalen, 2005).

Coastal peat marshes are especially susceptible to saltwater intrusion and changes in water depth (Herbert et al., 2015; Whittle and Gallego-Sala, 2016), but little is known about how exposure to salinity affects organic matter accumulation and peat stability. In areas with low inorganic sediment input, peatland soils can be highly organic ( $>65 \%$ organic matter) and vulnerable to external drivers, such as freshwater diversion and effects of climate change (Delaune et al., 1994; McVoy et al., 2011). The Everglades is the largest coastal peatland in the United States $\left(>6000 \mathrm{~km}^{2}\right.$; Richardson et al., 2008) and one of the most vulnerable to SLR, as $60 \%$ of Everglades National Park (ENP) is at or below $0.9 \mathrm{~m}$ in elevation (Pearlstine et al., 2010). Freshwater flow through the Everglades has been greatly reduced by compartmentalization (creation of water storage areas) and overall reduction in water delivery, resulting in less freshwater flow into the 
Everglades, leaving the ecosystem highly vulnerable to saltwater intrusion (Light and Dineen, 1994; Saha et al., 2011). The term "peat collapse" has been used to describe a relatively rapid shift in soil $\mathrm{C}$ balance, leading to a net loss of organic $\mathrm{C}$ and loss of soil elevation, culminating in a conversion of vegetated marsh to open water ponds (Delaune et al., 1994). This process has been documented to varying degrees in different coastal wetlands and has been attributed to changes in microbial processes, increased sulfate reduction, sulfide accumulation, eutrophication from excess nitrogen $(\mathrm{N})$ inputs, inadequate plant production, and vegetation damage from tropical storms, contributing to the instability of inland marshes (Cahoon et al., 2003; Deegan et al., 2012; Delaune et al., 1994; Voss et al., 2013). Areas of peat collapse have been observed in the brackish and saline marsh areas of the coastal Everglades (Fig. 1), yet the mechanisms behind this collapse are not understood (Chambers et al., 2015; Wanless and Vlaswinkel, 2005). Therefore, understanding how factors associated with SLR that exacerbate saltwater intrusion in the coastal Everglades and potentially alter $\mathrm{C}$ storage and peat stability is critically important for the future of Everglades coastal wetlands.

Past studies have identified $\mathrm{C}$ responses to salinity or water depth in soils (Chambers et al., 2013; Chambers et al., 2011; Marton et al., 2012; Weston et al., 2006; Weston et al., 2011), but fewer have investigated interactions between soil and plant processes in vegetated soil systems (Neubauer, 2013; Neubauer et al., 2000; Weston et al., 2014). The drivers and mechanisms of peat collapse may be different depending on the presence or absence of plants. The interaction between plant production and soil functions play an integral role in the persistence of coastal wetlands, and, therefore, understanding responses of soils, as well as the interaction with plants, to elevated 
salinity and water depth is crucial to interpreting these studies and to understanding applicability to coastal peat marsh vulnerability.

To examine the influence of salt exposure and inundation on soil and plant processes driving coastal peat marsh $\mathrm{C}$ cycling, we conducted two mesocosm experiments using Everglades brackish marsh monoliths: one experiment examined responses in peat soils without plants to determine soil responses in the absence of plants ("soil-only"); the other evaluated plant and peat soil responses to determine their interaction effect ("plant-soil"). We conducted two separate experiments on different habitats within the marsh because, given the loss of vegetation and formation of open water ponds that is predicted to occur with saltwater intrusion, $\mathrm{C}$ and soil biogeochemical cycling will likely be altered after a marsh transitions to an open water pond (Spivak et al., 2017). Within the soil-only experiment, we hypothesized that elevated salinity would increase overall soil $\mathrm{CO}_{2}$ efflux, with the greatest effect occurring after initial exposure. We predicted that elevated salinity would decrease $\mathrm{CH}_{4}$ efflux, as sulfate replaced $\mathrm{CH}_{4}$ as the terminal electron acceptor, while higher water depth would increase $\mathrm{CH}_{4}$ efflux given more reduced conditions. In the plant-soil experiment, we hypothesized that elevated salinity would decrease GEP while increasing ER and soil $\mathrm{CO}_{2}$ efflux, leading to decreased NEP and a change in the marsh from a net $\mathrm{C}$ sink to a $\mathrm{C}$ source. We also hypothesized that higher water depth would decrease soil $\mathrm{CO}_{2}$ efflux as a result of more reducing conditions, mitigating some of the effects of elevated salinity and dampening the overall loss of $\mathrm{C}$ to the atmosphere. When considering the transition from a vegetated to non-vegetated marsh, we predicted that soil $\mathrm{CO}_{2}$ efflux would decelerate because of a reduction in labile $\mathrm{C}$ inputs from vegetation and no active root respiration occurring. 


\section{MATERIALS AND METHODS}

\section{Soil-only experiment}

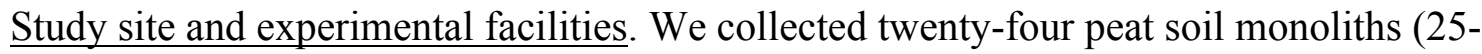
cm deep $\times 28$-cm diameter) on 22 July 2014 from a brackish marsh of Shark River Slough $\left(25^{\circ} 13^{\prime} 13.52^{\prime \prime} \mathrm{N}, 80^{\circ} 50^{\prime} 36.70^{\prime \prime} \mathrm{W}\right)$ in ENP, a supratidal location about 5-km inland from Florida Bay. The site was dominated by dense sawgrass patches (Cladium jamaicense), interspersed with buttonwood (Conocarpus erectus) and open water ponds with senescing and dead sawgrass plants. Peat was approximately $1 \mathrm{~m}$ deep to a $\sim 0.5 \mathrm{~m}$ mineral layer overlying limestone bedrock. The soil total $\mathrm{C}$ content within the top $10-\mathrm{cm}$ at this site was $42.6 \pm 0.2 \%$ (mean \pm 1 standard error from 5 cores), bulk density was $0.133 \pm 0.008 \mathrm{~g} \mathrm{~cm}^{-3}, 84.5 \pm 0.5 \%$ of the soil was organic matter, and water occupied $88.5 \pm 0.8 \%$ of the pore space. At the time of collection, ambient porewater salinity was $\sim 9$ ppt. Anecdotal evidence suggests this was a freshwater peat marsh in 1952 (Beard et al. 1952). We excavated the peat monoliths intact using shovels and placed them into perforated buckets with mesh screen over the perforations that allowed water exchange while minimizing sediment loss (Chambers et al., 2013). Extracted monoliths were dug out slightly larger than the size of the bucket and were shaved down to a uniform size while being placed into the bucket. Monoliths were transported to an outdoor mesocosm facility at ENP's Florida Bay Interagency Science Center (FBISC) in Key Largo, FL.

We used a randomized split-plot experimental design with repeated measurements. The two manipulated factors were salinity (the whole-plot factor with two nested blocks) and inundation (the sub-plot factor), which were both fixed factors. Once 
on site, monoliths were carefully immersed in six 250 -gallon concrete tanks equipped with an adjustable inflow spigot, a $30-\mathrm{cm}$ tall standpipe to maintain consistent water level, and an outflow drain; three tanks had elevated salinity (20 ppt), while three had ambient salinity (10 ppt). Within each tank, the water depth for a monolith was controlled by setting it on the bottom of the tank (completely submerged) or by setting it on a shelf in the tank that elevated the surface of the monoliths $\sim 4 \mathrm{~cm}$ above water surface (exposed). The monoliths were randomly assigned to either an elevated salinity or ambient salinity tank and to either completely submerged or exposed water depth.

Salinity was controlled by mixing water weekly to desired experimental salinity concentrations from four 2,000-gallon head tanks, 2 with freshwater and 2 with saltwater, and the mixture was pumped at a constant flow $\left(36-\mathrm{mL} \mathrm{min}^{-1}\right)$ into each mesocosm tank. Freshwater was collected from a nearby canal and had similar nutrient concentrations to freshwater portions of the Everglades (C-111; 2517'31.74" N, 80²7'21.59" W). Saltwater head tanks were equipped with a pump to draw water from adjacent Florida Bay.

The soil monoliths were allowed to acclimate for 3 weeks under ambient salinity $(\sim 10 \mathrm{ppt})$ and completely inundated conditions before treatment manipulation and measurements began. The "exposed" designated monoliths were then raised to $\sim 4-\mathrm{cm}$ above the water surface before the commencement of the two experiments. There were two phases in the experiment: an 8-day "ramp up" period (Aug 20-28, 2014) in which salinity was incrementally raised from ambient (10 ppt) to treatment (20 ppt) salinity, and, immediately following, a 12-week "press" period (Sep to Nov 2014) in which salinity remained elevated. The four treatments were designated as: (1) Amb.Sub, (2) 
Amb.Exp, (3) Salt.Sub, (4) Salt.Exp, where the salinity treatment was defined as either ambient (Amb) or elevated (Salt), and the inundation treatment was defined as either completely submerged (Sub) or top 4-cm of soil exposed above the water surface (Exp).

$\underline{\text { Surface water and soil porewater physicochemistry. Surface water in each tank was }}$ collected weekly using a $60-\mathrm{mL}$ syringe and field filtered through $0.7-\mu \mathrm{M}$ glass fiber filters (GFF) into acid washed plastic bottles. At the time of collection, temperature $\left({ }^{\circ} \mathrm{C}\right)$, salinity (ppt), and $\mathrm{pH}$ was measured on samples of freshwater source, saltwater source, and tank surface water using a YSI Model 600 XL (Xylem, Inc., Yellow Springs, OH, USA). Soluble reactive phosphorus (SRP), total dissolved P (TDP), and dissolved inorganic N (DIN) was analyzed at the South Florida Water Management District Water Quality Laboratory on a four-channel Lachat Flow Injection Analyzer 5000 auto-analyzer (Lachat Instruments, Loveland, $\mathrm{CO}, \mathrm{USA})$. Sulfate $\left(\mathrm{SO}_{4}{ }^{2-}\right)$ was analyzed using an ion chromatograph (Metrohm 881, Riverview, FL, USA). Dissolved organic C (DOC) was analyzed using a Shimadzu TOC-L analyzer (Shimadzu Scientific Instruments, Columbia, MD, USA; Eaton et al., 2005).

Porewater sippers [plastic tubing attached an air stone (4-cm long x 1-cm diameter)] were inserted to $15-\mathrm{cm}$ depth near the middle of each monolith. Porewater was collected weekly using a $60-\mathrm{mL}$ syringe by placing suction on the sipper and evacuating the tubing before collecting a sample. Water was filtered $(0.7-\mu \mathrm{M}$ GFF) into unused plastic bottles. Porewater was analyzed for temperature, salinity, and $\mathrm{pH}$ immediately after collection. Dissolved constituents (SRP, TDP, DOC, DIN, $\mathrm{SO}_{4}{ }^{2-}$ ) were analyzed as described above. 
$\underline{\mathrm{CO}}_{2}$ and $\mathrm{CH}_{4}$ efflux. Prior to the beginning the experiment, one 10-cm diameter PVC collar was installed 5-cm into the soil of each peat monolith for soil $\mathrm{C}$ efflux measurements. During the "ramp up" period of the soil-only experiment, soil $\mathrm{CO}_{2}$ efflux was measured daily for 120 seconds using a portable infrared gas analyzer (Li-Cor 8100, Lincoln, NE, USA; Chambers et al., 2013). Soil $\mathrm{CO}_{2}$ efflux was measured weekly during the "press" period.

Methane was measured biweekly on a subset of monoliths during the "press" period using the LI-8100 modified to collect a subset of air for trace gas sampling (Chambers et al., 2013). Four out of the six monoliths for each treatment $(n=16)$ were randomly chosen at the beginning of the experiment, and measurements occurred weekly on the same monoliths. The chamber was sealed for $15 \mathrm{~min}$ and $25-\mathrm{mL}$ of gas was withdrawn using a $60-\mathrm{mL}$ syringe at both the beginning and end of the 15 -min sampling period from a port in-line with the instrument; the gas was sealed in a 20 -mL evacuated glass vial and transported back to the lab for analysis. Samples were run on a gas chromatograph (Shimadzu Scientific Instruments GC 8A, Columbia, MD, USA) fitted with a flame ionization detector. Methane flux was calculated as the slope of $\mathrm{CH}_{4}$ concentration over time.

\section{Plant-soil experiment}

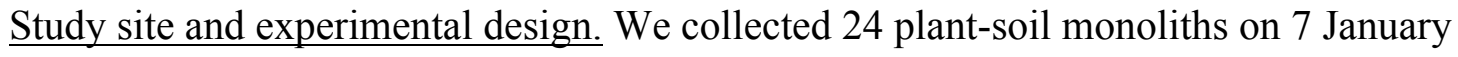
2015 from the same site as described above using the same method except that monoliths had sawgrass plants (C. jamaicense) as well as soil. On site, areas with $\sim 3$ plant culms 
per $0.06 \mathrm{~m}^{-2}$ were selected for monolith collection. Monoliths were transported to FBISC and allowed to equilibrate at ambient (10 ppt) and inundated conditions for one month. The experimental design was identical to the previous experiment except there was a more gradual "ramp-up" period (three months) in which salinity was raised from ambient (10 ppt) to $20 \mathrm{ppt}$ in the elevated salinity treatments. The second experiment lasted a total of 18 months from February 2015 to July 2016.

Surface water and soil porewater physicochemistry. Surface water and porewater was collected and analyzed monthly using the same methods described above. Sulfide (HS $\left.{ }^{-}\right)$ was measured using standard methods (McKee et al., 1988). Soil redox potential was measured monthly using standard techniques (Faulkner et al., 1989). We inserted three platinum-tipped probes to a depth of $5-\mathrm{cm}$ in each monolith and allowed to equilibrate for 30 minutes until measurements were taken.

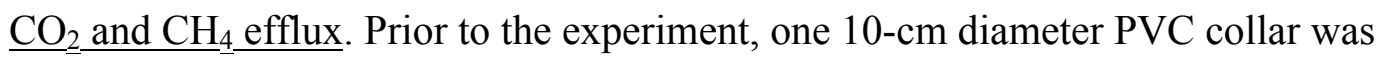
installed 5-cm into the soil in each monolith to allow for soil $\mathrm{C}$ efflux to be measured. Soil $\mathrm{CO}_{2}$ efflux was measured monthly using the methods described above. Soil $\mathrm{CH}_{4}$ was measured using the methods described above. During the first year, soil $\mathrm{CH}_{4}$ was measured monthly, but because of the lack of detectable flux, soil $\mathrm{CH}_{4}$ efflux measurements were cut to bi-monthly for the last 6 months. Soil $\mathrm{CO}_{2}$ and $\mathrm{CH}_{4}$ efflux were not measured in April 2015 because of equipment failure. 


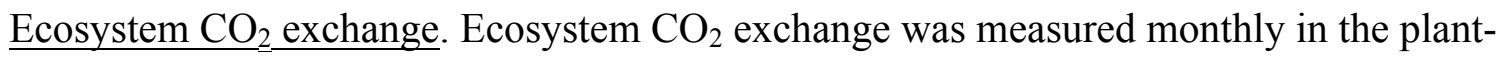
soil experiment with a transparent static chamber $(53 \mathrm{~L} \times 38 \mathrm{~W} \times 150 \mathrm{H} \mathrm{cm})$ placed over the monoliths and sealed (Neubauer, 2013; Weston et al., 2014; Wilson et al., 2015). The chamber was equipped with two fans to circulate air. Carbon flux measurements were made in full light near solar noon and in the dark. After sealing the chamber, the system was allowed to equilibrate for 2 mins, then change in $\mathrm{CO}_{2}$ concentration was recorded every second for 3 mins. During flux measurements, air was pumped from the chamber to a calibrated $\mathrm{CO}_{2} / \mathrm{H}_{2} \mathrm{O}$ gas analyzer (LI-COR model LI-840, Lincoln, NE, USA) placed in-line with the chamber. In between light and dark sampling, the chamber top was removed and allowed to equilibrate with atmospheric conditions. NEP was measured in full light, while ecosystem respiration of $\mathrm{CO}_{2}\left(\mathrm{ER}_{\mathrm{CO} 2}\right)$ was measured in the dark immediately after light measurements by covering the chamber with a dark cloth, blocking out all sunlight. GEP was calculated from NEP and $\mathrm{ER}_{\mathrm{CO} 2}$ as:

$-G E P=-N E P-E R_{C O 2}$

where NEP is instantaneous $\mathrm{CO}_{2}$ flux $\left(\mu \mathrm{mol} \mathrm{m}{ }^{-2} \mathrm{~s}^{-1}\right)$ in light and $\mathrm{ER}_{\mathrm{CO} 2}$ is the $\mathrm{CO}_{2}$ flux in the dark.

Aboveground biomass. Aboveground net primary productivity (ANPP) in the plant-soil experiment was measured non-destructively at bimonthly intervals following methods described in Daoust \& Childers (1998). Briefly, each sawgrass culm was tagged and the number of live and dead leaves, shoot height, and culm diameter were measured. Change in aboveground biomass and ANPP were calculated using previously derived allometric relationships between plant height, culm diameter, and biomass (Childers et al., 2006). 
Data analyses. Statistical analysis was performed using R (R Core Team 2013). Linear mixed models (Package "nlme", Pinheiro et al. 2017) were used to examine the relationship among physicochemistry of surface and porewater, soil oxidation-reduction potential, C flux, and ANPP and the independent variable of salinity, inundation, and time (fixed factors). To compare between the two experiments, experimental type replaced time in the linear mixed model. Because of the split-plot, nested nature of our experimental design, each salinity tank was set as a block (random factor), while inundation was nested within each block. Normality and homoscedasticity were tested by visually inspecting plotted residuals, and data was log-transformed to increase heteroscedasticity when necessary. The relationship between soil redox potential and temperature was determined using a Pearson product-moment correlation. Culm density was compared between the beginning and end of the experiment for each treatment individually using a paired $t$-test, while culm density among treatments was compared using a $t$-test. Linear regressions were used to determine the relationships between GEP, $\mathrm{NEP}, \mathrm{ER}_{\mathrm{CO} 2}$ and sawgrass biomass. Significance for all analyses was determined by an alpha level of 0.05 .

\section{RESULTS}

Surface and porewater physicochemistry. In the soil-only experiment, surface water was maintained at a salinity of $11.5 \pm 0.3 \mathrm{ppt}$ for the 3 -week acclimation period. During the 8day "ramp-up" period, we increased surface water salinity at 1 ppt day ${ }^{-1}$ in the salinity treatment until we reached our target salinity; surface water salinity remained constant for 
the duration of the 12-week experiment (Table S1). Porewater salinity closely mirrored surface water salinity for the experimental period (Table 1; Table S1). Surface water temperature over the experiment ranged from 18.0 to $34.3{ }^{\circ} \mathrm{C}$ but remained similar between the ambient and elevated salinity tanks (Table S1). Mean $\mathrm{pH}$ was more acidic in porewater than in surface water (Table 1; Table S1). Elevated salinity resulted in significantly higher porewater $\mathrm{SO}_{4}{ }^{2-}$ compared to ambient salinity $\left(F_{(1,4)}=5.42, p=0.028\right.$; Table S2). Full mixed model results for porewater physicochemistry are available in Table S2.

In the plant-soil experiment, surface water temperature ranged from 18.5 to $37.2^{\circ} \mathrm{C}$ (Table S1). Surface water salinity was maintained at $8 \mathrm{ppt}$ during the 1-month acclimation period. Averaged over the entire experiment, surface water salinity was relatively stable and near experimental targets in both the ambient and elevated salinity treatments, with some variation because of rainfall and evaporation (Table S1). Averaged over the entire experiment, porewater salinities were more stable than surface water salinities (Table 1; Table S1). The elevated salinity treatment resulted in significantly higher porewater $\mathrm{SO}_{4}{ }^{2-}\left(F_{(1,4)}=204.97, p<0.001\right)$ compared to the ambient salinity treatment (Table S2). Full mixed model results for porewater physicochemistry are available in Table S2. Soil redox potential at 5-cm depth in the plant-soil experiment ranged from +12.3 mV (Amb.Exp, Mar 2015) to +309.4 mV (Amb.Exp, May 2016; Fig. S1). Redox potential varied temporally, with the lowest values occurring in summer 2015, then gradually rising for the duration of the experiment (Fig. S1). Redox was negatively correlated to temperature (Person's $r(343)=-0.198, p<0.001$ ). 
When compared across the same time frame, there were significant differences in all mean porewater constituents between the two experiments $(p<0.001$; Tables $1, \mathrm{~S} 3)$. Mean porewater $\mathrm{pH}, \mathrm{DOC}, \mathrm{NH}_{4}{ }^{+}, \mathrm{TDN}, \mathrm{TDP}$, and SRP were all significantly higher in the plant-soil experiment, while mean porewater $\mathrm{SO}_{4}{ }^{2-}$ was significantly higher in the soil-only experiment (Table 1).

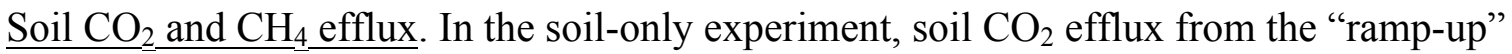
phase was analyzed separately from the "press" phase because the experimental manipulation was different during these two time periods. During the 8-day "ramp-up", both salinity and inundation had a significant effect on soil $\mathrm{CO}_{2}$ efflux (Table 2). Elevated salinity and lower water level caused soil $\mathrm{CO}_{2}$ efflux to increase by $91 \%$ compared to the ambient salinity and higher water level monoliths (Fig. 2). During the 12-week "press" phase, soil $\mathrm{CO}_{2}$ efflux did not differ with either salinity or inundation (Table 2; Fig. 3b). Soil $\mathrm{CH}_{4}$ efflux was very low, ranging from $-3.7 \mathrm{nmol} \mathrm{CH}_{4} \mathrm{~m}^{-2} \mathrm{~s}^{-1}$ (Salt.Sub, Feb 2015) to $20.6 \mathrm{nmol} \mathrm{CH}_{4} \mathrm{~m}^{-2} \mathrm{~s}^{-1}$ (Salt.Exp, Feb 2015), with no differences with salinity and inundation (Table 2, Fig. 3a).

In the plant-soil experiment, soil $\mathrm{CO}_{2}$ efflux varied across the experimental period, with larger efflux during the first half of the experiment and diminished fluxes during the second half with differences between the treatments (Fig. 4b). Soil $\mathrm{CO}_{2}$ efflux ranged from $-0.08 \mu \mathrm{mol} \mathrm{CO} \mathrm{CO}^{-2} \mathrm{~s}^{-1}$ (Amb.Sub, Apr 2016) to $1.86 \mu \mathrm{mol} \mathrm{CO} \mathrm{CO}^{-2} \mathrm{~s}^{-1}$ (Salt.Exp, May 2015). Over the entire experiment, inundation led to less soil $\mathrm{CO}_{2}$ efflux compared to the exposed monoliths $(p=0.004)$, but the effect of salinity was not significant ( $p=0.834$; Tables 2,3 ). Soil $\mathrm{CH}_{4}$ efflux was very low, ranging from -3.6 
nmol $\mathrm{CH}_{4} \mathrm{~m}^{-2} \mathrm{~s}^{-1}$ (Amb.Sub, Sep 14, 2014) to $6.2 \mathrm{nmol} \mathrm{CH}_{4} \mathrm{~m}^{-2} \mathrm{~s}^{-1}$ (Salt.Sub, Sep 14, 2014), with no significant differences with either salinity or inundation (Fig. 4a; Table 2).

During the same three months in which soil $\mathrm{CO}_{2}$ and $\mathrm{CH}_{4}$ flux measurements were taken (Sep 1 to Dec 1) for the soil-only (2014) and plant-soil (2015) experiments, there was a small, but significant, difference of $2.9^{\circ} \mathrm{C}$ in surface water temperature $\left(F_{(1,327)}=87.71, p<0.001\right)$. Soil $\mathrm{CO}_{2}$ efflux was different between the two experiments $\left(F_{(1,272)}=14.74, p<0.001\right.$; Table S3). Specifically, soil $\mathrm{CO}_{2}$ efflux was higher in the exposed monoliths with plants than compared to those without plants $\left(F_{(1,272)}=7.11\right.$, $p=0.008$; Tables 5, S3). Soil $\mathrm{CH}_{4}$ efflux also varied across inundation and experiment, with lower fluxes from the submerged monoliths with plants compared to the submerged monoliths without plants $\left(F_{(1,226)}=7.21, p=0.007\right.$; Tables $\left.5, \mathrm{~S} 3\right)$

Ecosystem exchange. Across the 18-month sampling period during the plant-soil experiment, calculated GEP at solar noon ranged from $0.16 \mu \mathrm{mol} \mathrm{CO} \mathrm{C}^{-2} \mathrm{~s}^{-1}$ (median for Salt.Exp plots, May 2015) to $4.1 \mu \mathrm{mol} \mathrm{CO}_{2} \mathrm{~m}^{-2} \mathrm{~s}^{-1}$ (median for Amb.Exp plots, Feb 2016, Fig. 5a). Across all treatments, GEP was higher during the second year compared to the first (Fig. 5a), while overall, elevated salinity led to less $\mathrm{CO}_{2}$ uptake compared to the ambient conditions ( $p=0.003$; Table 3 ). Ecosystem respiration of $\mathrm{CO}_{2}$ ranged from 0.19 $\mu \mathrm{mol} \mathrm{CO} 2 \mathrm{~m}^{-2} \mathrm{~s}^{-1}$ (median rates, Salt.Sub plots, Oct 2015) to $1.3 \mu \mathrm{mol} \mathrm{CO} \mathrm{m}^{-2} \mathrm{~s}^{-1}$ (Amb.Exp, Jun 2016, Fig. 5b). Both salinity and inundation had significant effects on $\mathrm{ER}_{\mathrm{CO} 2}(p<0.05$; Table 2$)$. With both high and low water levels, $\mathrm{ER}_{\mathrm{CO} 2}$ was decreased by $47 \%$ and $37 \%$ with elevated salinity, respectively (Table 3 ). Within both salinity treatments, inundation resulted in significantly less $\mathrm{ER}_{\mathrm{CO} 2}$ (Table 3$) . \mathrm{ER}_{\mathrm{CO} 2}$ did not vary 
much for all treatments for the entire study period (Fig. 5b). NEP ranged from $-0.37 \mu \mathrm{mol}$ $\mathrm{CO}_{2} \mathrm{~m}^{-2} \mathrm{~s}^{-1}$ (median for Salt.Exp, Mar 2015) to $4.1 \mu \mathrm{mol} \mathrm{CO} \mathrm{CO}^{-2} \mathrm{~s}^{-1}$ (Amb.Exp, Dec 2015, Fig. 5c). Overall, elevated salinity led to less $\mathrm{CO}_{2}$ uptake ( $\left.p=0.003\right)$, while there was no effect of inundation on NEP ( $p=0.308$; Tables 2,3$)$.

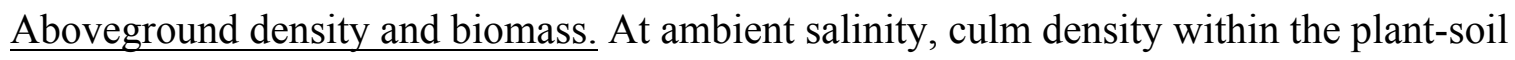

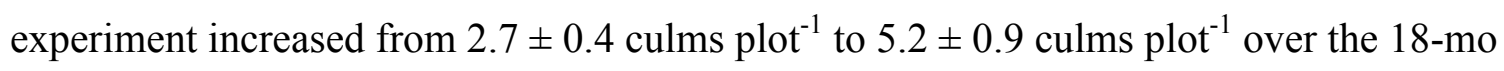
experiment $(t=3.61, p<0.01)$. At elevated salinity, culm density remained unchanged $(2.6$ \pm 0.5 culms plot $^{-1}$ to $3.2 \pm 0.6$ culms $\left.\operatorname{plot}^{-1} ; t=1.86, p=0.09\right)$ over the same period, so that by the end of the experiment, there was a significant difference in culm density between the ambient salinity and elevated salinity monoliths $(t=2.72, p=0.01)$. There was no change in culm density within the submerged treatment from the beginning to the end of the experiment $\left(2.8 \pm 0.3\right.$ culms plot $^{-1}$ to $3.8 \pm 0.7$ culms $\left.\operatorname{clot}^{-1} ; t=2.00, p=0.07\right)$. Exposed

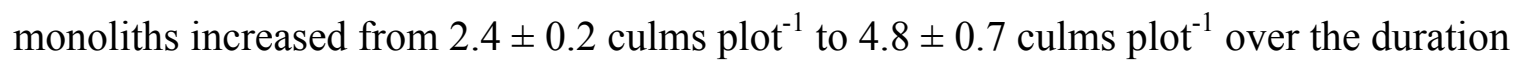
of the experiment $(t=3.44, p<0.01)$. At the end of the experiment, however, there were no significant differences in culm density between the inundated and exposed monoliths $(t=1.66, p=0.11)$. Salinity reduced ANPP $(p=0.038)$, but inundation had no effect on ANPP ( $p=0.199$; Table 2, Fig. 6). GEP was significantly related to biomass in all treatments, whereas GEP was only correlated to $\mathrm{ER}_{\mathrm{CO} 2}$ in the Amb.Exp treatment (Table 4).

\section{DISCUSSION}

Our objective was to understand how specific stressors of SLR and saltwater intrusion (i.e., elevated salinity and increased water depth) would affect coastal wetland 
$\mathrm{C}$ and soil biogeochemical dynamics and how these processes influence peat collapse. To do this, we compared extracted monoliths from an intact plant-soil marsh to a nearby open-water pond that contained only soil. Soil $\mathrm{CO}_{2}$ efflux spiked with initial exposure to salinity in the soil-only experiment, but this effect did not persist for the duration of the experiment, while enhanced soil exposure had no effect on soil $\mathrm{CO}_{2}$ efflux. In the plantsoil experiment, soil $\mathrm{CO}_{2}$ efflux was not affected by salinity, but was influenced by soil exposure. Elevated salinity, regardless of inundation level, significantly reduced C uptake by the marsh by reducing NEP (Table 3). The decline in NEP was not caused by an increase in soil respiration or ER but rather by a substantial decrease in plant productivity and GEP. Our results are consistent with increasing numbers of studies showing significant changes to ecosystem $\mathrm{C}$ cycling in marshes experiencing saltwater intrusion (Herbert et al., 2015; Neubauer, 2013). Below, we examine how elevated salinity and water depth influence coastal wetland $\mathrm{C}$ processing from both plant-soil matrices and degraded soils. We then consider the implications $\mathrm{C}$ processing may have on coastal wetland survival, given accelerating SLR.

\section{Effects of salinity and inundation on peat soils}

Numerous studies have shown varying responses of soil $\mathrm{CO}_{2}$ efflux with saltwater intrusion into freshwater wetland soils (Chambers et al., 2011; Weston et al., 2011), yet few have tested this response on brackish water wetland soils. Without plants, soil $\mathrm{CO}_{2}$ efflux significantly increased with initial elevated salinity and soil exposure (Fig. 2). This may be attributed to a combination of enhanced oxidation with exposure and the delivery

of more $\mathrm{SO}_{4}{ }^{2-}$ ions associated with elevated salinity, as sulfate reduction has been shown 
to become the dominant pathway of organic matter oxidation as salinity increases (Table 1; Weston et al., 2006; Weston et al., 2011). Chambers et al. (2011) reported a similar spike in $\mathrm{CO}_{2}$ efflux after exposing freshwater marsh soils to elevated salinity seawater; this spike in $\mathrm{CO}_{2}$ efflux also diminished over time. Chambers et al. (2011) concluded that this was a result of excess $\mathrm{SO}_{4}{ }^{2-}$ present in seawater because they did not see the same spike in $\mathrm{CO}_{2}$ efflux when exposing the soils to deionized water mixed with $\mathrm{NaCl}$. Results from this study and that of Chambers et al. (2011) are consistent with Edmonds et al. (2009), who showed that microbes switch biogeochemical pathways (i.e., from methanogenesis to $\mathrm{SO}_{4}{ }^{2-}$ reduction) and gene expression and regulation over very short times following saltwater exposure. After the one-week "ramp up", the effect of elevated salinity on increasing $\mathrm{CO}_{2}$ efflux diminished, resulting in no further differences in $\mathrm{CO}_{2}$ efflux across treatments (Fig. 3b). We expected to see higher soil $\mathrm{CO}_{2}$ efflux under conditions of soil exposure, as oxygen can diffuse through the sediments faster in air than in water, allowing for alleviation of electron pressure and higher $\mathrm{C}$ mineralization (Wright and Reddy, 2001). However, we saw no effect of inundation on soil $\mathrm{CO}_{2}$ efflux in the soil-only experiment. Our relatively small exposure height (soil surface 4-cm above water surface) could have kept the soil surface saturated and anoxic via capillary action (Agosta, 1985; Nyman and Delaune, 1991). The short duration of the experiment (3 months in fall/winter) could also have resulted in our missing this response because of seasonal effects (Phillips et al., 2010). 


\section{Effects of salinity and inundation on sawgrass peat marshes}

Salinity has been shown to lead to both positive and negative feedbacks on soil respiration (Stagg et al., 2017). Elevated salinity can increase soil $\mathrm{CO}_{2}$ efflux, as seen in the soil-only experiment (see above). However, elevated salinity in our study did not affect soil $\mathrm{CO}_{2}$ efflux. With plants present, inundation, but not salinity, had a significant effect on soil $\mathrm{CO}_{2}$ efflux (Table 2). As expected, enhanced soil exposure to the atmosphere led to more $\mathrm{CO}_{2}$ efflux, likely because of oxygen availability, which enhances microbial respiration (Reddy and DeLaune, 2008). In a similar experimental study, Chambers et al. (2013) also found that elevating salinity in mangrove peat soils (16.6 to $32.6 \mathrm{ppt}$ ) did not change the rate of soil $\mathrm{CO}_{2}$ efflux. Because our soils were already brackish in nature, elevating salinity from 10 to $20 \mathrm{ppt}$ likely did not affect microbial processes, especially considering that water for our elevated salinity treatment was sourced from an estuary with high salinity ( $\sim 38 \mathrm{ppt}$, Table S1). By using seawater to elevate salinity, we likely changed the microbial structure and function of the soil microbial community to become more salt tolerant (Andronov et al., 2012; Yan et al., 2015), which may explain why ER was unchanged. Soil $\mathrm{CH}_{4}$ efflux in this experiment was also low and not affected by salinity or inundation (Table 3), which is expected from brackish wetland soils where methanogenesis is low (Wilson et al., 2015). High concentrations of porewater $\mathrm{SO}_{4}{ }^{2-}$ and $\mathrm{HS}^{-}$usually result in high rates of sulfate reduction compared to methanogenesis (Capone and Kiene, 1988). A large proportion of $\mathrm{CH}_{4}$ flux is lost to the atmosphere through aerenchyma present in macrophytes in wetland ecosystems (Laanbroek, 2010; Whiting and Chanton, 1993), C. jamaicense does not have 
flow-through aerenchyma (Chabbi et al., 2000) and therefore does not have an enhanced pathway for $\mathrm{CH}_{4}$ evasion through plants to the atmosphere.

Small increases in salinity can significantly impact gas exchange in wetland plants (Pezeshki et al., 1989). Continuously elevated salinity reduced GEP by 74 and $70 \%$ compared to the ambient salinity-inundated and -exposed treatments, respectively (Table 5). Our finding is consistent with previous field and laboratory experiments that show significant reduction in plant productivity given elevated salinity, the potential mechanisms of which are detailed in other studies (Herbert et al., 2015; Neubauer, 2013). Elevated salinity decreased $\mathrm{ER}_{\mathrm{CO} 2}$ by 47 and $37 \%$ compared to the ambient salinitysubmerged and -exposed conditions, respectively (Table 3). As there was no change in soil $\mathrm{CO}_{2}$ efflux with elevated salinity, the decrease in $\mathrm{ER}_{\mathrm{CO} 2}$ seen in our experiment can be attributed to decreased leaf respiration. Additionally, $\mathrm{ER}_{\mathrm{CO} 2}$ was relatively stable throughout the entire experiment with very little monthly variation and was not correlated to GEP in most treatments (Fig. 5, Table 4). This runs counter to similar studies that show that GEP and $\mathrm{ER}_{\mathrm{CO} 2}$ are highly correlated and decrease in similar proportions with elevated salinity (Neubauer, 2013; Weston et al., 2014). Greater inundation decreased $\mathrm{ER}_{\mathrm{CO} 2}$, which was directly tied to a decrease in soil $\mathrm{CO}_{2}$ efflux (Table 3). Overall, elevated salinity decreased NEP by 86 and $88 \%$ compared to ambient salinity with inundated and exposed conditions, respectively (Table 3). Although there were a few months in which NEP was negative (Fig. 4c), indicating the marsh was a net source of $\mathrm{CO}_{2}$ to the atmosphere, averaged over the entire experimental period, elevated salinity did not lead to a net efflux of $\mathrm{CO}_{2}$. However, our measurements were taken near solar noon and on sunny days and represent the maximum GEP potential of the vegetation. 
Therefore, we performed an exercise to integrate our data over a daily, and subsequently, an annual time frame. We took previously derived light response curves for a brackish $C$. jamaicense marsh (Wilson et al., 2015) and used standard methods to estimate annual flux (Neubauer, 2013; Wilson et al., 2015). Briefly, we took our measurement made in full light for each month and scaled it to 5 different rates and different light levels using the previously derived light response curve for that same month (Wilson et al., 2015). We used temperature and light (PAR) data from a nearby weather tower (MBTS, DBHydro, South Florida Water Management District) to determine the maximum light level for that day. We then used standard equations to estimate daily, monthly, and annual flux (Neubauer, 2013; Wilson et al., 2015).

After daily integration, we found that all treatments were a net source of $\mathrm{CO}_{2}$ to the atmosphere, with elevated salinity and soil exposure greatly amplifying $\mathrm{CO}_{2}$ loss (Fig. 7). This was mostly driven by a sharp decline in GEP with elevated salinity, with only a disproportionate decline in $\mathrm{ER}$, leading to larger $\mathrm{CO}_{2}$ loss. The effect of elevated salinity was largest when the soils were exposed. As the historical sheet flow of water to the southern coastal Everglades has been significantly reduced over the past century (McVoy et al., 2011), greater duration of dry down and soil exposure, coupled with increasing porewater salinity, has likely contributed to significantly altering the flow of $\mathrm{CO}_{2}$ through the marsh and the atmosphere. Given current restoration efforts to restore more sheet flow to the southern Everglades (Perry, 2004), more water could lead to fewer periods of dry down and lessen the loss of $\mathrm{C}$ from brackish water marshes experiencing saltwater intrusion. While elevated salinity accelerates $\mathrm{CO}_{2}$ loss from the marsh, even under ambient salinity conditions, we found the marsh to be a net source of $\mathrm{CO}_{2}$ to the 
atmosphere. The brackish marsh where we chose to conduct this study had already experienced visual evidence of peat collapse (Fig. 1), and our finding of the marsh as a net source of $\mathrm{CO}_{2}$ to the atmosphere under ambient conditions may help explain this collapse.

\section{Plant losses mediate C flux and biogeochemistry}

Within a single marsh, vegetation cover can vary heterogeneously, and biogeochemical processing can vary depending on the presence of plants (Spivak et al., 2017). We found that the presence of plants led to different soil $\mathrm{CO}_{2}$ efflux rates with both elevated salinity and water depth. Overall, we saw no effect of elevated salinity on soil $\mathrm{CO}_{2}$ efflux in either experiment (Table 2). However, compared across experiments with and without plants, effects of elevated salinity and inundation point to the importance of wetland plants in influencing soil respiration. Although these experiments were not conducted in tandem, the experimental conditions were similar, meriting comparison among flux responses (Table S1).

We expected to see higher soil $\mathrm{CO}_{2}$ efflux under conditions of soil exposure during both experiments, as oxygen can diffuse through the sediments faster in air than in water, allowing for alleviation of electron pressure and enhanced $\mathrm{C}$ mineralization (Wright and Reddy, 2001). However, we saw no effect of inundation on soil $\mathrm{CO}_{2}$ efflux in the soil-only experiment. Our relatively small exposure height (soil surface 4-cm above water surface) could have kept the soil surface saturated and anoxic via capillary action (Agosta, 1985; Nyman and Delaune, 1991). On the contrary, with plants present, soil $\mathrm{CO}_{2}$ efflux was 3-5 times higher than soil monoliths without plants only when the 
soil surface was exposed (Table 5). Although $C$. jamaicense does not use active transport of oxygen to alleviate anoxic root stress, passive transport still occurs (Chabbi et al., 2000). This mechanism of obtaining oxygen, not present in soils without plants, could lead to more oxidized conditions, stimulate aerobic respiration, and therefore lead to the greater $\mathrm{CO}_{2}$ efflux we observed in monoliths with plants as compared to those without. Roots are another factor that could be causing this discrepancy in soil $\mathrm{CO}_{2}$ efflux across experiments. Root respiration has been shown to account for anywhere between 22 and $81 \%$ of overall soil respiration (Li et al., 2016; Wang et al., 2006). Under inundated conditions, root respiration is likely to be diminished as plants will retain oxygen in order to avoid resorting to alcoholic fermentation, a process that produces ethanol, a plant toxin (Vartapetian and Jackson, 1997). Under exposed conditions, anoxia stress in plants is alleviated, allowing for enhanced root respiration (Pezeshki and DeLaune, 2012).

\section{Global implications of saltwater intrusion on $C$ in coastal wetlands}

A number of studies have shown significant changes to ecosystem $\mathrm{C}$ cycling in marshes experiencing saltwater intrusion (Herbert et al., 2015; Neubauer, 2013). However, few of these studies focused on coastal peatlands. Our study illustrates how saltwater intrusion alters ecosystem $\mathrm{C}$ cycling, resulting in less $\mathrm{CO}_{2}$ uptake, and how the interaction with greater inundation depth had little influence on aspects of $\mathrm{C}$ cycling that we measured. These results indicate that a sustained increase in salinity in brackish coastal marshes, an issue facing coastal wetlands globally, substantially alters $\mathrm{C}$ cycling and could disrupt and change ecosystem structure and function. As climate change and increased human alteration of hydrologic cycles continues, instances of wetland 
salinization will increase (Herbert et al., 2015). Although the specific responses to increased salinization will vary on a case-by-case basis, depending on frequency and magnitude of exposure, initial soil conditions, hydrologic flow, etc., our results indicated that elevated salinity in coastal wetlands has the potential to dramatically decrease NEP and stimulate $\mathrm{CO}_{2}$ evasion from the marsh (Fig. 7). Peat soils, and the stabilization of these soils, depend on the input of organic material for their existence. Without this input, destabilization of peat soils could occur, potentially leading to collapse and conversion from a marsh to an open pond habitat (Delaune et al., 1994). In freshwater and brackish marshes, the potential for peat collapse also is affected by the ability of other, more salttolerant, plant species to migrate in and stabilize the soil (Donnelly and Bertness, 2001; Langley et al., 2013; Smith, 2009). Saltwater intrusion into coastal wetlands is occurring worldwide (Herbert et al., 2015), and the rate will only increase with accelerated SLR. Elevated salinity is usually coupled with other pressures facing coastal wetlands, such as drought (Ardon et al., 2013), altered hydrologic regimes (Green et al., 2017), eutrophication (Deegan et al., 2012), and anthropogenic barriers to migration (Enwright et al., 2016), all potentially interacting to influence the ability of these ecosystems to store globally relevant amounts of organic $\mathrm{C}$.

Our findings showed that saltwater intrusion affected plant $\mathrm{C}$ cycling much more than soil C cycling in brackish coastal peatlands, yet little is known about wetland plant tolerance ranges and adaptability. Additional research is needed to investigate these tolerance ranges to accurately quantify coastal marsh vulnerability to peat collapse. Specific areas of focus should also include investigating saltwater intrusion effects into freshwater marshes, measuring in situ field responses, and investigating how saltwater 
intrusion interacts with other climate drivers, such as drought, to potentially influence peat collapse. With many large-scale coastal restoration plans currently being implemented or in development (US Government Accountability Office, 2007; National Academies of Sciences, Engineering, and Medicine, 2016), understanding how current climate change stressors will affect coastal wetlands is essential.

\section{ACKNOWLEDGEMENTS}

Funding for research was supported by Florida Sea Grant R/C-S-56, including cooperative agreements with the South Florida Water Management District, the Everglades Foundation, and Everglades National Park. Additional funding was provided through the National Science Foundation's Florida Coastal Everglades Long Term Ecological Research Program (DEB-1237517). We thank Shawn Abrahams, Laura Bauman, Kristina Morales, and Ryan Stolee for help in the field. Viviana Mazzei and Fred Sklar provided valuable feedback on early drafts of this manuscript. We also are grateful to two anonymous reviewers who also provided valuable feedback that greatly improved this manuscript. Benjamin Wilson was supported by a Florida International University Teaching Assistantship, Florida Sea Grant, FCE LTER, and FIU Dissertation Year Fellowship. This is contribution $\mathrm{xxxx}$ of the Southeast Environmental Research Center.

\section{LITERATURE CITED}

Agosta, K. (1985). The effect of tidally induced changes in the creekbank water-table on pore water chemistry. Estuarine Coastal and Shelf Science, 21(3), 389-400. doi:10.1016/0272-7714(85)90019-8

Andronov, E. E., Petrova, S. N., Pinaev, A. G., Pershina, E. V., Rakhimgalieva, S. Z., Akhmedenov, K. M., Sergaliev, N. K. (2012). Analysis of the structure of 
microbial community in soils with different degrees of salinization using T-RFLP and real-time PCR techniques. Eurasian Soil Science, 45(2), 147-156.

doi:10.1134/s1064229312020044

Ardon, M., Morse, J. L., Colman, B. P., \& Bernhardt, E. S. (2013). Drought-induced saltwater incursion leads to increased wetland nitrogen export. Global Change Biology, 19(10), 2976-2985. doi:10.1111/gcb.12287

Baustian, J. J., Mendelssohn, I. A., \& Hester, M. W. (2012). Vegetation's importance in regulating surface elevation in a coastal salt marsh facing elevated rates of sea level rise. Global Change Biology, 18(11), 3377-3382. doi:10.1111/j.13652486.2012.02792.x

Cahoon, D. R., Hensel, P., Rybczyk, J., McKee, K. L., Proffitt, C. E., \& Perez, B. C. (2003). Mass tree mortality leads to mangrove peat collapse at Bay Islands, Honduras after Hurricane Mitch. Journal of Ecology, 91(6), 1093-1105. doi:10.1046/j.1365-2745.2003.00841.x

Capone, D. G., \& Kiene, R. P. (1988). Comparison of microbial dynamics in marine and fresh water sediments - contrasts in anaerobic carbon catabolism. Limnology and Oceanography, 33(4), 725-749.

Chabbi, A., McKee, K. L., \& Mendelssohn, I. A. (2000). Fate of oxygen losses from Typha domingensis (Typhaceae) and Cladium jamaicense (Cyperaceae) and consequences for root metabolism. American Journal of Botany, 87(8), 10811090. doi:10.2307/2656644

Chambers, L. G., Davis, S. E., \& Troxler, T. G. (2015). Sea Level Rise in the Everglades: Plant-Soil-Microbial Feedbacks in Response to Changing Physical Conditions. In J. A. Entry (Ed.), Microbiology of the Everglades Ecosystem (pp. 89-112). Boca Raton: CRC Press.

Chambers, L. G., Davis, S. E., Troxler, T. T., Boyer, J. N., Downey-Wall, A., \& Scinto, L. J. (2013). Biogeochemical effects of simulated sea level rise on carbon loss in an Everglades mangrove peat soil. Hydrobiologia, doi 10.1007/s10750-1001311764-10756.

Chambers, L. G., Reddy, K. R., \& Osborne, T. Z. (2011). Short-Term Response of Carbon Cycling to Salinity Pulses in a Freshwater Wetland. Soil Science Society of America Journal, 75(5), 2000-2007. doi:10.2136/sssaj2011.0026

Childers, D. L., Iwaniec, D., Rondeau, D., Rubio, G., Verdon, E., \& Madden, C. J. (2006). Responses of sawgrass and spikerush to variation in hydrologic drivers and salinity in Southern Everglades marshes. Hydrobiologia, 569, 273-292. doi:10.1007/s 10750-006-0137-9 
Daoust, R. J., \& Childers, D. L. (1998). Quantifying aboveground biomass and estimating net aboveground primary production for wetland macrophytes using a nondestructive phenometric technique. Aquatic Botany, 62(2), 115-133. doi:10.1016/s0304-3770(98)00078-3

Deegan, L. A., Johnson, D. S., Warren, R. S., Peterson, B. J., Fleeger, J. W., Fagherazzi, S., \& Wollheim, W. M. (2012). Coastal eutrophication as a driver of salt marsh loss. Nature, 490(7420), 388-+. doi:10.1038/nature 11533

Delaune, R. D., Nyman, J. A., \& Patrick, W. H. (1994). Peat collapse, ponding and wetland loss in a rapidly submerging coastal marsh. Journal of Coastal Research, 10(4), 1021-1030.

Donnelly, J. P., \& Bertness, M. D. (2001). Rapid shoreward encroachment of salt marsh cordgrass in response to accelerated sea-level rise. Proceedings of the National Academy of Sciences of the United States of America, 98(25), 14218-14223. doi:10.1073/pnas.251209298

Eaton, A. D., Clesceri, L. S., Rice, E. W., \& Greenberg, A. E. (2005). Standard methods for the examination of water and wastewater: centennial edition (21 ed.). Washington, D.C.: American Public Health Association.

Edmonds, J. W., Weston, N. B., Joye, S. B., Mou, X. Z., \& Moran, M. A. (2009). Microbial Community Response to Seawater Amendment in Low-Salinity Tidal Sediments. Microbial Ecology, 58(3), 558-568. doi:10.1007/s00248-009-9556-2

Engle, V. D. (2011). Estimating the Provision of Ecosystem Services by Gulf of Mexico Coastal Wetlands. Wetlands, 31(1), 179-193. doi:10.1007/s13157-010-0132-9

Enwright, N. M., Griffith, K. T., \& Osland, M. J. (2016). Barriers to and opportunities for landward migration of coastal wetlands with sea-level rise. Frontiers in Ecology and the Environment, 14(6), 307-316. doi:10.1002/fee.1282

Faulkner, S. P., Patrick, W. H., \& Gambrell, R. P. (1989). Field techniques for measuring wetland soil parameters. Soil Science Society of America Journal, 53(3), 883-890.

Green, A. J., Alcorlo, P., Peeters, E., Morris, E. P., Espinar, J. L., Bravo-Utrera, M. A, Scheffer, M. (2017). Creating a safe operating space for wetlands in a changing climate. Frontiers in Ecology and the Environment, 15(2), 99-107. doi:10.1002/fee.1459

Herbert, E. R., Boon, P., Burgin, A. J., Neubauer, S. C., Franklin, R. B., Ardon, M.,Gell, P. (2015). A global perspective on wetland salinization: ecological consequences of a growing threat to freshwater wetlands. Ecosphere, 6(10). doi:10.1890/es1400534.1 
Jackson, M. B., \& Colmer, T. D. (2005). Response and adaptation by plants to flooding stress - Preface. Annals of Botany, 96(4), 501-505. doi:10.1093/aob/mci205

Kirwan, M. L., \& Megonigal, J. P. (2013). Tidal wetland stability in the face of human impacts and sea-level rise. Nature, 504(7478), 53-60. doi:10.1038/nature12856

Laanbroek, H. J. (2010). Methane emission from natural wetlands: interplay between emergent macrophytes and soil microbial processes. A mini-review. Annals of Botany, 105(1), 141-153. doi:10.1093/aob/mcp201

Langley, J. A., Mozdzer, T. J., Shepard, K. A., Hagerty, S. B., \& Megonigal, J. P. (2013). Tidal marsh plant responses to elevated $\mathrm{CO} 2$, nitrogen fertilization, and sea level rise. Global Change Biology, 19(5), 1495-1503. doi:10.1111/gcb.12147

Larcher, W. (2003). Physiological plant ecology (4th ed.). Berlin: Springer.

Li, Y. C., Hou, C. C., Song, C. C., \& Guo, Y. D. (2016). Seasonal changes in the contribution of root respiration to total soil respiration in a freshwater marsh in Sanjiang Plain, Northeast China. Environmental Earth Sciences, 75(10). doi:10.1007/s12665-016-5592-7

Light, S. S., \& Dineen, J. W. (1994). Water control in the Everglades: A historical perspective. In S. M. Davis \& J. C. Ogden (Eds.), Everglades: The Ecosystem and its Restoration (pp. 47-84). Delray Beach: St. Lucie Press.

Marton, J. M., Herbert, E. R., \& Craft, C. B. (2012). Effects of Salinity on Denitrification and Greenhouse Gas Production from Laboratory-incubated Tidal Forest Soils. Wetlands, 32(2), 347-357. doi:10.1007/s13157-012-0270-3

McKee, K. L. (2011). Biophysical controls on accretion and elevation change in Caribbean mangrove ecosystems. Estuarine Coastal and Shelf Science, 91(4), 475-483. doi:10.1016/j.ecss.2010.05.001

McKee, K. L., Mendelssohn, I. A., \& Hester, M. W. (1988). Reexamination of pore water sulfide concentrations and redox potentials near the aerial roots of Rhizophora mangle and Avicennia germinans. American Journal of Botany, 75(9), 13521359. doi: $10.2307 / 2444458$

McLeod, E., Chmura, G. L., Bouillon, S., Salm, R., Bjork, M., Duarte, C. M., Silliman, B. R. (2011). A blueprint for blue carbon: toward an improved understanding of the role of vegetated coastal habitats in sequestering CO2. Frontiers in Ecology and the Environment, 9(10), 552-560. doi:10.1890/110004

McVoy, C. W., Said, W. P., Obeysekera, J., Van Arman, J., \& Dreschel, T. W. (2011). Landscapes and Hydrology of the Predrainage Everglades. Gainesville, FL: University of Florida Press. 
Morris, J. T., Sundareshwar, P. V., Nietch, C. T., Kjerfve, B., \& Cahoon, D. R. (2002). Responses of coastal wetlands to rising sea level. Ecology, 83(10), 2869-2877. doi: $10.2307 / 3072022$

Morse, J. L., Ardon, M., \& Bernhardt, E. S. (2012). Greenhouse gas fluxes in southeastern U.S. coastal plain wetlands under contrasting land uses. Ecological Applications, 22(1), 264-280.

National Academies of Sciences, Engineering, and Medicine. 2016. Progress Toward Restoring the Everglades: The Sixth Biennial Review - 2016. Washington, DC: The National Academies Press. https://doi.org/10.17226/23672.

Neubauer, S. C. (2013). Ecosystem responses of a tidal freshwater marsh experiencing saltwater intrusion and altered hydrology. Estuaries and Coasts, 36(3), 491-507. doi:10.1007/s12237-011-9455-X

Neubauer, S. C., Miller, W. D., \& Anderson, I. C. (2000). Carbon cycling in a tidal freshwater marsh ecosystem: a carbon gas flux study. Marine Ecology-Progress Series, 199, 13-30.

Nyman, J. A., \& Delaune, R. D. (1991). $\mathrm{CO}_{2}$ emission and soil Eh responses to different hydrological conditions in fresh, brackish, and saline marsh soils. Limnology and Oceanography, 36(7), 1406-1414.

Nyman, J. A., Walters, R. J., Delaune, R. D., \& Patrick, W. H., Jr. (2006). Marsh vertical accretion via vegetative growth. Estuarine Coastal and Shelf Science, 69(3-4), 370-380. doi:10.1016/j.ecss.2006.05.041

Pearlstine, L. G., Pearlstine, E. V., \& Aumen, N. G. (2010). A review of the ecological consequences and management implications of climate change for the Everglades. Journal of the North American Benthological Society, 29(4), 1510-1526. doi:10.1899/10-045.1

Perry, W. (2004). Elements of South Florida's Comprehensive Everglades Restoration Plan. Ecotoxicology, 13(3), 185-193. doi:10.1023/B:ECTX.0000023564.10311.4a

Pezeshki, S. R., \& DeLaune, R. D. (2012). Soil oxidation-reduction in wetlands and its impact on plant functioning. Biology, 1(2), 196-221.

Pezeshki, S. R., DeLaune, R. D., \& Patrick Jr., W. H. (1987). Response of the freshwater marsh species, Panicum hemitomon Schult., to increased salinity. Freshwater Biology, 1, 195-200. 
Pezeshki, S. R., Delaune, R. D., \& Patrick, W. H. (1987). Effects of flooding and salinity on photosynthesis of Sagittaria lancifolia. Marine Ecology Progress Series, 41(1), 87-91. doi:10.3354/meps041087

Pezeshki, S. R., Delaune, R. D., \& Patrick, W. H. (1989). Assessment of saltwater intrusion impact on gas exchange behavior of Louisiana Gulf Coast wetland species. Wetland Ecology and Management, 1(1), 21-30.

Phillips, S. C., Varner, R. K., Frolking, S., Munger, J. W., Bubier, J. L., Wofsy, S. C., \& Crill, P. M. (2010). Interannual, seasonal, and diel variation in soil respiration relative to ecosystem respiration at a wetland to upland slope at Harvard Forest. Journal of Geophysical Research-Biogeosciences, 115. doi:10.1029/2008jg000858

Pinheiro J., Bates D., DebRoy S., Sarkar D., and R Core Team (2017). nlme: Linear and Nonlinear Mixed Effects Models. R package version 3.1-131, https:/CRAN.Rproject.org/package $=$ nlme.

Poffenbarger, H. J., Needelman, B. A., \& Megonigal, J. P. (2011). Salinity influence on methane emissions from tidal marshes. Wetlands, 31(5), 831-842. doi:10.1007/s13157-011-0197-0

Reddy, K. R., \& DeLaune, R. D. (2008). Biogeochemistry of wetlands: science and applications. Boca Raton: CRC Press.

Rejmankova, E., \& Macek, P. (2008). Response of root and sediment phosphatase activity to increased nutrients and salinity. Biogeochemistry, 90(2), 159-169. doi:10.1007/s 10533-008-9242-3

Richardson, C. J., Dickson, A., \& Ho, M. (2008). The Effects of Disturbance, Phosphorus, and Water Level on Plant Succession in the Everglades. In Everglades Experiments (pp. 531-544). New York: Springer.

Ryan, M. G., \& Law, B. E. (2005). Interpreting, measuring, and modeling soil respiration. Biogeochemistry, 73(1), 3-27. doi:10.1007/s10533-004-5167-7

Saha, A. K., Saha, S., Sadle, J., Jiang, J., Ross, M. S., Price, R. M., . . Wendelberger, K. S. (2011). Sea level rise and South Florida coastal forests. Climatic Change, 107(1-2), 81-108. doi:10.1007/s10584-011-0082-0

Schedlbauer, J. L., Oberbauer, S. F., Starr, G., \& Jimenez, K. L. (2010). Seasonal differences in the $\mathrm{CO}(2)$ exchange of a short-hydroperiod Florida Everglades marsh. Agricultural and Forest Meteorology, 150(7-8), 994-1006. doi:10.1016/j.agrformet.2010.03.005 
Smith, S. M. (2009). Multi-decadal Changes in Salt Marshes of Cape Cod, MA: Photographic Analyses of Vegetation Loss, Species Shifts, and Geomorphic Change. Northeastern Naturalist, 16(2), 183-208. doi:10.1656/045.016.0203

Spivak, A. C., Gosselin, K., Howard, E., Mariotti, G., Forbrich, I., Stanley, R., \& Sylva, S. P. (2017). Shallow ponds are heterogeneous habitats within a temperate salt marsh ecosystem. Journal of Geophysical Research-Biogeosciences, 122(6), 1371-1384. doi:10.1002/2017jg003780

Stagg, C. L., Schoolmaster, D. R., Krauss, K. W., Cormier, N., \& Conner, W. H. (2017). Causal mechanisms of soil organic matter decomposition: deconstructing salinity and flooding impacts in coastal wetlands. Ecology, 98(8), 2003-2018. doi:10.1002/ecy.1890

United States Government Accountability Office (GAO). (2007). Coastal Wetlands: Lessons Learned from Past Efforts in Louisiana Could Help Guide Future Restoration and Protection; Washington, DC, http://www.gao.gov/new.items/d08130.pdf

Valentine, D. L. (2002). Biogeochemistry and microbial ecology of methane oxidation in anoxic environments: a review. Antonie Van Leeuwenhoek International Journal of General and Molecular Microbiology, 81(1-4), 271-282. doi:10.1023/a:1020587206351

Vartapetian, B. B., \& Jackson, M. B. (1997). Plant adaptations to anaerobic stress. Annals of Botany, 79, 3-20.

Voss, C. M., Christian, R. R., \& Morris, J. T. (2013). Marsh macrophyte responses to inundation anticipate impacts of sea-level rise and indicate ongoing drowning of North Carolina marshes. Marine Biology, 160(1), 181-194. doi:10.1007/s00227012-2076-5

Wang, W., Guo, J. X., Feng, J., \& Oikawa, T. (2006). Contribution of root respiration to total soil respiration in a Leymus chinensis (Trin.) Tzvel. grassland of northeast China. Journal of Integrative Plant Biology, 48(4), 409-414. doi:10.1111/j.17447909.2006.00241.x

Wanless, H. R., \& Vlaswinkel, B. M. (2005). Coastal landscape and channel evolution affecting critical habitats at Cape Sable, Everglades National Park, Florida. Report to Everglades National Park. 197 pp.

Wdowinski, S., Bray, R., Kirtman, B. P., \& Wu, Z. H. (2016). Increasing flooding hazard in coastal communities due to rising sea level: Case study of Miami Beach, Florida. Ocean \& Coastal Management, 126, 1-8. doi:10.1016/j.ocecoaman.2016.03.002 
Weston, N. B., Dixon, R. E., \& Joye, S. B. (2006). Ramifications of increased salinity in tidal freshwater sediments: Geochemistry and microbial pathways of organic matter mineralization. Journal of Geophysical Research-Biogeosciences, 111, doi: 10.1029/2005JG000071. doi:10.1029/2005jg000071

Weston, N. B., Neubauer, S. C., Velinsky, D. J., \& Vile, M. A. (2014). Net ecosystem carbon exchange and the greenhouse gas balance of tidal marshes along an estuarine salinity gradient. Biogeochemistry, 120, 163-189.

Weston, N. B., Vile, M. A., Neubauer, S. C., \& Velinsky, D. J. (2011). Accelerated microbial organic matter mineralization following salt-water intrusion into tidal freshwater marsh soils. Biogeochemistry, 102(1-3), 135-151. doi:10.1007/s10533010-9427-4

Whalen, S. C. (2005). Biogeochemistry of methane exchange between natural wetlands and the atmosphere. Environmental Engineering Science, 22(1), 73-94. doi:10.1089/ees.2005.22.73

Whiting, G. J., \& Chanton, J. P. (1993). Primary production control of methane emissions from wetlands Nature, 364(6440), 794-795. doi:10.1038/364794a0

Whittle, A., \& Gallego-Sala, A. V. (2016). Vulnerability of the peatland carbon sink to sea-level rise. Scientific Reports, 6. doi:10.1038/srep28758

Wichern, J., Wichern, F., \& Joergensen, R. G. (2006). Impact of salinity on soil microbial communities and the decomposition of maize in acidic soils. Geoderma, 137(1-2), 100-108. doi:10.1016/j.geoderma.2006.08.001

Wilson, B. J., Mortazavi, B., \& Kiene, R. P. (2015). Spatial and temporal variability in carbon dioxide and methane exchange at three coastal marshes along a salinity gradient in a northern Gulf of Mexico estuary. Biogeochemistry, 123(3), 329-347. doi:10.1007/s 10533-015-0085-4

Wright, A. L., \& Reddy, K. R. (2001). Heterotrophic microbial activity in northern Everglades wetland soils. Soil Science Society of America Journal, 65(6), 18561864.

Yan, N., Marschner, P., Cao, W., Zuo, C., \& Qin, W. (2015). Influence of salinity and water content on soil microorganisms. International Soil and Water Conservation Research, 3, 316-323. 
TABLES

Table 1. Porewater salinity, $\mathrm{pH}$, redox, and dissolved constituents for the soil-only experiment. Data represents mean $\pm 1 \mathrm{SE}(n=6$ replicates); see linear mixed model results (Table S2) for significant differences between the two experiments. $\mathrm{DOC}^{-\mathrm{NH}_{4}}{ }^{+}, \mathrm{TDN}^{2}$ and $\mathrm{SO}_{4}{ }^{2-}$ are in $\mathrm{mg} \mathrm{L}^{-1}, \mathrm{HS}^{-}$is in $\mathrm{mM}$, TDP and SRP are $\mu \mathrm{M} \mathrm{L}^{-1}$, and redox potential is in $\mathrm{mV}$. Amb $=$ Ambient salinity, Salt $=$ Elevated Salinity, Sub $=$ Submerged, Exp $=$ Exposed.

\begin{tabular}{|c|c|c|c|c|c|c|c|c|c|}
\hline & & \multicolumn{3}{|c|}{3 month Means: Sep to Dec } & \multicolumn{4}{|c|}{18 month Means } & \multirow[b]{2}{*}{ Salt.Exp } \\
\hline & & Amb.Sub & Amb.Exp & Salt.Sub & Salt.Exp & Amb.Sub & Amb.Exp & Salt.Sub & \\
\hline \multirow[t]{2}{*}{ Salinity } & Soil-Only & $10.3 \pm 0.5$ & $10.3 \pm 0.3$ & $20.2 \pm 0.6$ & $20.3 \pm 0.4$ & & & & \\
\hline & Plant-Soil & $9.5 \pm 0.2$ & $9.4 \pm 0.2$ & $19.0 \pm 0.3$ & $18.9 \pm 0.3$ & $9.5 \pm 0.2$ & $9.8 \pm 0.3$ & $18.9 \pm 0.5$ & $19 \pm 0.6$ \\
\hline \multirow[t]{2}{*}{ pH } & Soil-Only & $6.7 \pm 0.2$ & $6.9 \pm 0.2$ & $6.7 \pm 0.2$ & $6.6 \pm 0.2$ & & & & \\
\hline & Plant-Soil & $7.02 \pm 0.06$ & $7.01 \pm 0.04$ & $7.02 \pm 0.02$ & $7.04 \pm 0.04$ & $7.07 \pm 0.03$ & $7.07 \pm 0.03$ & $7.09 \pm 0.03$ & $7.09 \pm 0.03$ \\
\hline \multirow[t]{2}{*}{ DOC } & Soil-Only & $21.4 \pm 3.3$ & $15.7 \pm 2.7$ & $17.1 \pm 1.9$ & $18.9 \pm 1.3$ & & & & \\
\hline & Plant-Soil & $33.7 \pm 3$ & $30.9 \pm 1.9$ & $30.8 \pm 2.9$ & $31.5 \pm 2.3$ & $25.7 \pm 1.7$ & $26.6 \pm 1.8$ & $22.5 \pm 1.1$ & $26.4 \pm 1.5$ \\
\hline \multirow[t]{2}{*}{$\mathbf{N H}_{4}^{+}$} & Soil-Only & $0.41 \pm 0.08$ & $0.26 \pm 0.07$ & $0.53 \pm 0.09$ & $0.52 \pm 0.08$ & & & & \\
\hline & Plant-Soil & $0.85 \pm 0.12$ & $0.60 \pm 0.13$ & $0.67 \pm 0.08$ & $0.91 \pm 0.15$ & $0.56 \pm 0.05$ & $0.39 \pm 0.06$ & $0.55 \pm 0.03$ & $0.65 \pm 0.04$ \\
\hline \multirow[t]{2}{*}{ TDN } & Soil-Only & $1.12 \pm 0.22$ & $0.85 \pm 0.12$ & $1.14 \pm 0.12$ & $1.17 \pm 0.13$ & & & & \\
\hline & Plant-Soil & $2.02 \pm 0.18$ & $1.70 \pm 0.16$ & $1.80 \pm 0.10$ & $2.12 \pm 0.19$ & $1.64 \pm 0.09$ & $1.45 \pm 0.1$ & $1.59 \pm 0.08$ & $1.75 \pm 0.09$ \\
\hline \multirow[t]{2}{*}{$\mathrm{SO}_{4}{ }^{2-}$} & Soil-Only & $774 \pm 68$ & $782 \pm 65$ & $1617 \pm 118$ & $1643 \pm 129$ & & & & \\
\hline & Plant-Soil & $600 \pm 31$ & $630 \pm 29$ & $1457 \pm 33$ & $1390 \pm 38$ & $616 \pm 31$ & $641 \pm 28$ & $1380 \pm 46$ & $1362 \pm 52$ \\
\hline \multirow[t]{2}{*}{ TDP } & Soil-Only & $0.80 \pm 0.12$ & $0.42 \pm 0.07$ & $0.87 \pm 0.08$ & $0.66 \pm 0.02$ & & & & \\
\hline & Plant-Soil & $1.73 \pm 0.29$ & $1.42 \pm 0.25$ & $0.92 \pm 0.14$ & $1.61 \pm 0.30$ & $1.00 \pm 0.09$ & $0.78 \pm 0.08$ & $0.78 \pm 0.04$ & $1.14 \pm 0.08$ \\
\hline \multirow[t]{2}{*}{ SRP } & Soil-Only & $0.25 \pm 0.07$ & $0.09 \pm 0.03$ & $0.57 \pm 0.09$ & $0.34 \pm 0.12$ & & & & \\
\hline & Plant-Soil & $1.05 \pm 0.24$ & $0.88 \pm 0.22$ & $0.65 \pm 0.06$ & $1.32 \pm 0.29$ & $0.56 \pm 0.08$ & $0.43 \pm 0.07$ & $0.53 \pm 0.06$ & $0.71 \pm 0.06$ \\
\hline Redox & Plant-Soil & & & & & $170.0 \pm 16.0$ & $162.7 \pm 14.5$ & $168.3 \pm 18.2$ & $181.9 \pm 16.7$ \\
\hline $\mathbf{H S}^{-}$ & Plant-Soil & & & & & $0.41 \pm 0.11$ & $0.34 \pm 0.1$ & $0.43 \pm 0.09$ & $0.48 \pm 0.09$ \\
\hline
\end{tabular}


Table 2. Full statistical results for the linear mixed model run with time as an independent variable for $\mathrm{C}$ flux and aboveground net primary productivity (ANPP). Results with $\alpha<0.05$ are in bold. Data presented as $F$ (numerator degrees of freedom,denominator degrees of freedom $)=F$ value, $p=P$ value.

$G E P$ gross ecosystem productivity, $E R_{C O 2}$ ecosystem respiration of $\mathrm{CO}_{2}, N E P$ net ecosystem productivity.

\begin{tabular}{|c|c|c|c|c|c|c|c|c|}
\hline $\begin{array}{l}\text { Experime } \\
\text { nt }\end{array}$ & & Salinity & Inundation & Time & $\begin{array}{l}\text { Salinity* } \\
\text { Inundation }\end{array}$ & Salinity*Time & $\begin{array}{l}\text { Inundation* } \\
\text { Time }\end{array}$ & $\begin{array}{l}\text { Salinity* } \\
\text { Inundation* } \\
\text { Time }\end{array}$ \\
\hline \multirow[t]{3}{*}{ Soil Only } & $\begin{array}{l}\text { Soil } \mathrm{CO}_{2} \\
\text { ramp-up }\end{array}$ & $\begin{array}{l}F(1,4)=7.78 \\
p=0.049\end{array}$ & $\begin{array}{l}F(1,4)= \\
25.75 \\
p=0.007\end{array}$ & $\begin{array}{l}F(7,151)=4.22 \\
p=0.003\end{array}$ & $\begin{array}{l}F(1,4)= \\
2.22 \\
p=0.210\end{array}$ & $\begin{array}{l}F(7,151)=2.24 \\
p=0.033\end{array}$ & $\begin{array}{l}F(7,151)=3.34 \\
p=0.002\end{array}$ & $\begin{array}{l}F(7,151)=1.76 \\
p=0.099\end{array}$ \\
\hline & $\begin{array}{l}\text { Soil } \mathrm{CO}_{2} \\
\text { press }\end{array}$ & $\begin{array}{l}F(1,4)=0.47 \\
p=0.528\end{array}$ & $\begin{array}{l}F(1,4)=0.20 \\
p=0.671\end{array}$ & $\begin{array}{l}F(8,172)=2.75 \\
p=0.007\end{array}$ & $\begin{array}{l}F(1,4)= \\
1.14 \\
p=0.344\end{array}$ & $\begin{array}{l}F(8,172)=0.28 \\
p=0.971\end{array}$ & $\begin{array}{l}F(8,172)=2.26 \\
p=0.025\end{array}$ & $\begin{array}{l}F(8,172)=1.81 \\
p=0.076\end{array}$ \\
\hline & $\begin{array}{l}\text { Soil } \mathrm{CH}_{4} \\
\text { press }\end{array}$ & $\begin{array}{l}F(1,4)=0.20 \\
p=0.677\end{array}$ & $\begin{array}{l}F(1,3)=3.49 \\
p=0.158\end{array}$ & $\begin{array}{l}F(5,62)=1.99 \\
p=0.091\end{array}$ & $\begin{array}{l}F(1,3)= \\
0.15 \\
p=0.723\end{array}$ & $\begin{array}{l}F(5,62)=1.66 \\
p=0.155\end{array}$ & $\begin{array}{l}F(5,62)=1.15 \\
p=0.341\end{array}$ & $\begin{array}{l}F(5,62)=1.85 \\
p=0.115\end{array}$ \\
\hline \multirow[t]{6}{*}{ Plant-Soil } & Soil $\mathrm{CO}_{2}$ & $\begin{array}{l}F(1,4)=0.04 \\
p=0.834\end{array}$ & $\begin{array}{l}F(1,4)= \\
35.33 \\
p=0.004\end{array}$ & $\begin{array}{l}F(13,268)= \\
17.00 \\
P<0.001\end{array}$ & $\begin{array}{l}F(1,4)= \\
0.18 \\
p=0.692\end{array}$ & $\begin{array}{l}F(13,268)= \\
1.22 \\
p=0.260\end{array}$ & $\begin{array}{l}F(13,268)=8.67 \\
P<0.001\end{array}$ & $\begin{array}{l}F(13,268)=0.77 \\
p=0.682\end{array}$ \\
\hline & Soil $\mathrm{CH}_{4}$ & $\begin{array}{l}F(1,4)=1.10 \\
p=0.352\end{array}$ & $\begin{array}{l}F(1,4)=0.48 \\
p=0.523\end{array}$ & $\begin{array}{l}F(9,101)=0.60 \\
p=0.786\end{array}$ & $\begin{array}{l}F(1,4)= \\
0.24 \\
p=0.643\end{array}$ & $\begin{array}{l}F(9,101)=1.00 \\
p=0.443\end{array}$ & $\begin{array}{l}F(9,101)=0.65 \\
p=0.749\end{array}$ & $\begin{array}{l}F(9,101)=1.35 \\
p=0.221\end{array}$ \\
\hline & GEP & $\begin{array}{l}F(1,4)=37.43 \\
p=0.003\end{array}$ & $\begin{array}{l}F(1,4)=3.28 \\
p=0.143\end{array}$ & $\begin{array}{l}F(12,142)= \\
21.16 \\
P<0.001\end{array}$ & $\begin{array}{l}F(1,4)= \\
0.42 \\
p=0.550\end{array}$ & $\begin{array}{l}F(12,142)= \\
8.06 \\
P<0.001\end{array}$ & $\begin{array}{l}F(12,142)=8.81 \\
P<0.001\end{array}$ & $\begin{array}{l}F(12,142)=2.41 \\
p=0.007\end{array}$ \\
\hline & $\mathrm{ER}_{\mathrm{CO} 2}$ & $\begin{array}{l}F(1,4)=20.97 \\
p=0.010\end{array}$ & $\begin{array}{l}F(1,4)= \\
23.31 \\
p=0.008\end{array}$ & $\begin{array}{l}F(12,142)=8.36 \\
P<0.001\end{array}$ & $\begin{array}{l}F(1,4)= \\
0.03 \\
p=0.865\end{array}$ & $\begin{array}{l}F(12,142)= \\
9.26 \\
P<0.001\end{array}$ & $\begin{array}{l}F(12,142)=2.53 \\
p=0.004\end{array}$ & $\begin{array}{l}F(12,142)=1.07 \\
p=0.384\end{array}$ \\
\hline & NEP & $\begin{array}{l}F(1,4)=40.29 \\
p=0.003\end{array}$ & $\begin{array}{l}F(1,4)=1.35 \\
p=0.308\end{array}$ & $\begin{array}{l}F(13,155)= \\
33.73 \\
P<0.001\end{array}$ & $\begin{array}{l}F(1,4)= \\
0.98 \\
p=0.376\end{array}$ & $\begin{array}{l}F(13,155)= \\
7.71 \\
P<0.001\end{array}$ & $\begin{array}{l}F(13,155)=8.10 \\
P<0.001\end{array}$ & $\begin{array}{l}F(13,155)=1.92 \\
p=0.030\end{array}$ \\
\hline & ANPP & $\begin{array}{l}F(1,4)=9.27 \\
p=0.038\end{array}$ & $\begin{array}{l}F(1,4)=2.35 \\
p=0.199\end{array}$ & $\begin{array}{l}F(6,126)=11.44 \\
P<0.001\end{array}$ & $\begin{array}{l}F(1,4)= \\
2.23 \\
p=0.209\end{array}$ & $\begin{array}{l}F(6,126)=2.32 \\
p=0.036\end{array}$ & $\begin{array}{l}F(6,126)=0.91 \\
p=0.485\end{array}$ & $\begin{array}{l}F(6,126)=1.66 \\
p=0.134\end{array}$ \\
\hline
\end{tabular}


Table 3. Flux rates from the plant-soil experiment. Values represent the mean $\left(\mu\right.$ mol $\mathrm{CO}_{2}$ or $\left.\mathrm{CH}_{4} \mathrm{~m}^{-2} \mathrm{~s}^{-1}\right) \pm 1 \mathrm{SE}$ for soil $\mathrm{CO}_{2}(n=90)$, soil $\mathrm{CH}_{4}(n=36)$, gross ecosystem productivity (GEP), ecosystem respiration of $\mathrm{CO}_{2}\left(\mathrm{ER}_{\mathrm{CO} 2}\right)$, and net ecosystem productivity (NEP; $n=52$ ) compared over the entire experiment for each treatment for the plant-soil experiment. See mixed model results (Table 2) for significant differences. $\mathrm{Amb}=$ Ambient salinity, Salt $=$ Elevated Salinity, Sub $=$ Submerged, Exp $=$ Exposed.

\begin{tabular}{lrrrr}
\hline Flux & Amb.Sub & Amb.Exp & Salt.Sub & Salt.Exp \\
\hline Soil CO & $0.20 \pm 0.04$ & $0.79 \pm 0.12$ & $0.24 \pm 0.05$ & $0.72 \pm 0.14$ \\
Soil CH & $0.0032 \pm 0.0021$ & $0.0061 \pm 0.0018$ & $-0.0008 \pm 0.0018$ & $0.0034 \pm 0.0023$ \\
GEP & $6.13 \pm 0.44$ & $7.88 \pm 1.09$ & $1.61 \pm 0.13$ & $2.34 \pm 0.42$ \\
ER $_{\text {CO2 }}$ & $2.09 \pm 0.15$ & $2.97 \pm 0.22$ & $1.11 \pm 0.07$ & $1.88 \pm 0.10$ \\
NEP & $4.41 \pm 0.52$ & $5.70 \pm 1.16$ & $0.64 \pm 0.19$ & $0.70 \pm 0.49$ \\
\hline
\end{tabular}


Table 4. Coefficient of determination for linear relationships between Cladium jamaicense aboveground biomass and ecosystem $\mathrm{CO}_{2}$ exchange [gross ecosystem productivity (GEP), net ecosystem productivity (NEP), and ecosystem respiration $\left.\left(\mathrm{ER}_{\mathrm{CO} 2}\right)\right] . n s=$ non-significant $(p>0.05),{ }^{*} p \leq 0.05, * * p<0.01$

$\mathrm{Amb}=$ Ambient salinity, Salt $=$ Elevated Salinity, $\mathrm{Sub}=$ Submerged, $\mathrm{Exp}=$ Exposed.

\begin{tabular}{lrrrr}
\hline & $\begin{array}{c}\text { GEP vs. } \\
\text { Biomass }\end{array}$ & $\begin{array}{l}\text { NEP vs. } \\
\text { Biomass }\end{array}$ & $\begin{array}{c}\text { ER } \\
\text { Co2 } \\
\text { vs. } \\
\text { Biomass }\end{array}$ & $\begin{array}{c}\text { GEP vs. } \\
\text { ER }_{\text {CO2 }}\end{array}$ \\
\hline Treatment & $r^{2}$ & $r^{2}$ & $r^{2}$ & $r^{2}$ \\
Amb.Sub & $0.35^{* *}$ & $0.22^{*}$ & $0.22^{*}$ & $0.02 n s$ \\
Amb.Exp & $0.46^{* *}$ & $0.47^{* *}$ & $0.06 n s$ & $0.27^{* *}$ \\
Salt.Sub & $0.48^{* *}$ & $0.27^{*}$ & $0.24^{*}$ & $0.05 n s$ \\
Salt.Exp & $0.55^{* *}$ & $0.50^{* *}$ & $0.07 n s$ & $0.04 n s$ \\
\hline
\end{tabular}


Table 5. Soil $\mathrm{CO}_{2}$ and $\mathrm{CH}_{4}$ efflux compared across similar time periods and treatments for each experiment. Values represent the mean $\left(\mu \mathrm{mol} \mathrm{CO} \mathrm{Cr}_{2} \mathrm{CH}_{4} \mathrm{~m}^{-2} \mathrm{~s}^{-1}\right) \pm 1 \mathrm{SE}$. See mixed model results for significant differences between treatments (Table 2) and experiments (Table S3).

$\mathrm{Amb}=$ Ambient salinity, Salt $=$ Elevated Salinity, $\mathrm{Sub}=$ Submerged, Exp $=$ Exposed

\begin{tabular}{|c|c|c|c|}
\hline & & $\begin{array}{l}\text { Sep 1 - Nov } 30 \\
2014\end{array}$ & $\begin{array}{l}\text { Sep 1 - Nov } 30 \\
2015\end{array}$ \\
\hline & & Soil-only & Plant-soil \\
\hline Flux & Treatment & \multicolumn{2}{|c|}{ Rate $\left(\mu \mathrm{mol} \mathrm{m} \mathrm{m}^{-2} \mathrm{~s}^{-1}\right)$} \\
\hline \multirow[t]{4}{*}{ Soil $\mathrm{CO}_{2}$} & Amb.Sub & $0.32 \pm 0.04$ & $0.18 \pm 0.04$ \\
\hline & Amb.Exp & $0.25 \pm 0.04$ & $1.41 \pm 0.22$ \\
\hline & Salt.Sub & $0.34 \pm 0.05$ & $0.19 \pm 0.07$ \\
\hline & Salt.Exp & $0.35 \pm 0.03$ & $0.94 \pm 0.20$ \\
\hline \multirow[t]{4}{*}{ Soil $\mathrm{CH}_{4}$} & Amb.Sub & $0.0030 \pm 0.0019$ & $0.0009 \pm 0.0016$ \\
\hline & Amb.Exp & $0.0007 \pm 0.0003$ & $0.0027 \pm 0.0003$ \\
\hline & Salt.Sub & $0.0048 \pm 0.0028$ & $0.0002 \pm 0.0003$ \\
\hline & Salt.Exp & $0.0010 \pm 0.0007$ & $0.0007 \pm 0.0001$ \\
\hline
\end{tabular}




\section{FIGURES}

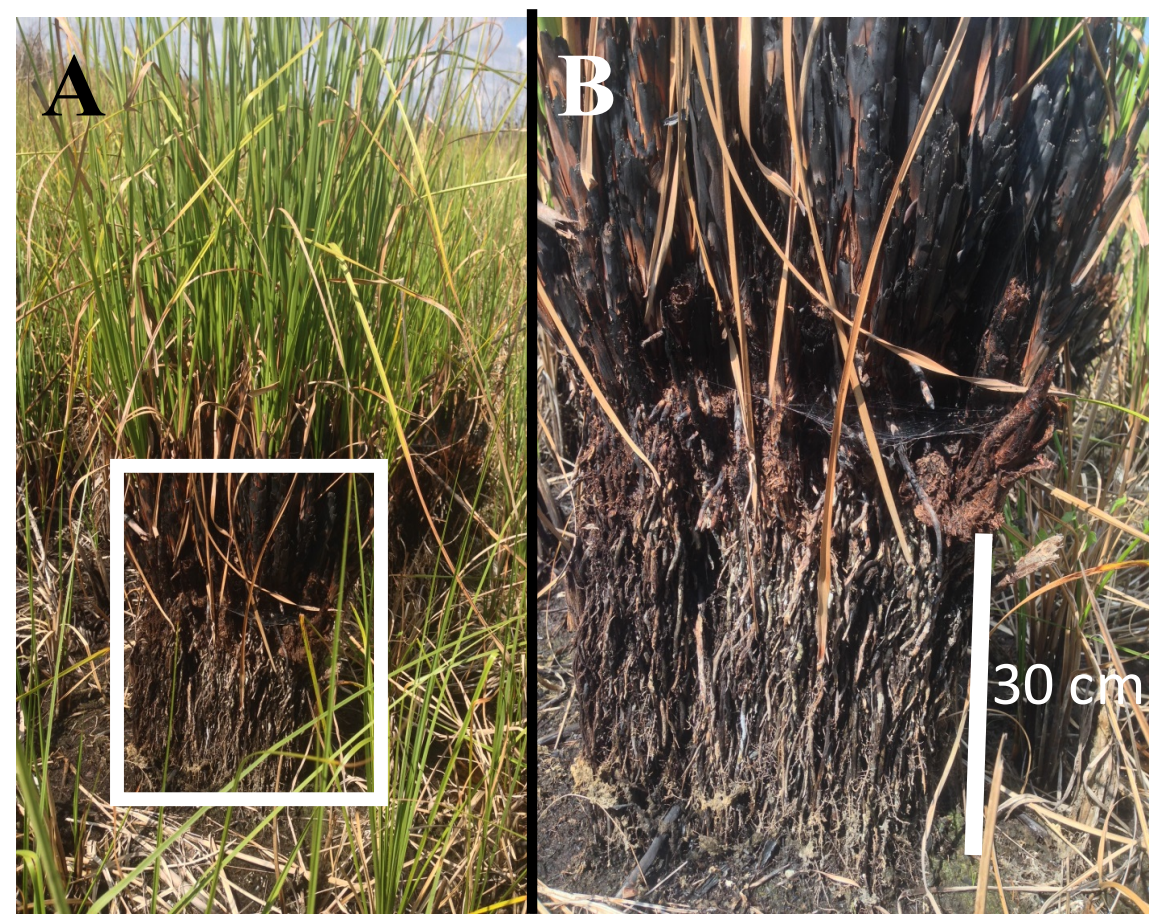

Figure 1. Photographs taken in March 2015 in the brackish water portion of Everglades National Park showing (A) a group of sawgrass culms forming a "pedestal" and (B) a close up of the culms and exposed roots. The delineation between the bottom of the culms and the exposed roots indicates that the surface of the soil has collapsed about 30 $\mathrm{cm}$ (distance from bottom of the culm to current soil surface) over an unknown period of time. 


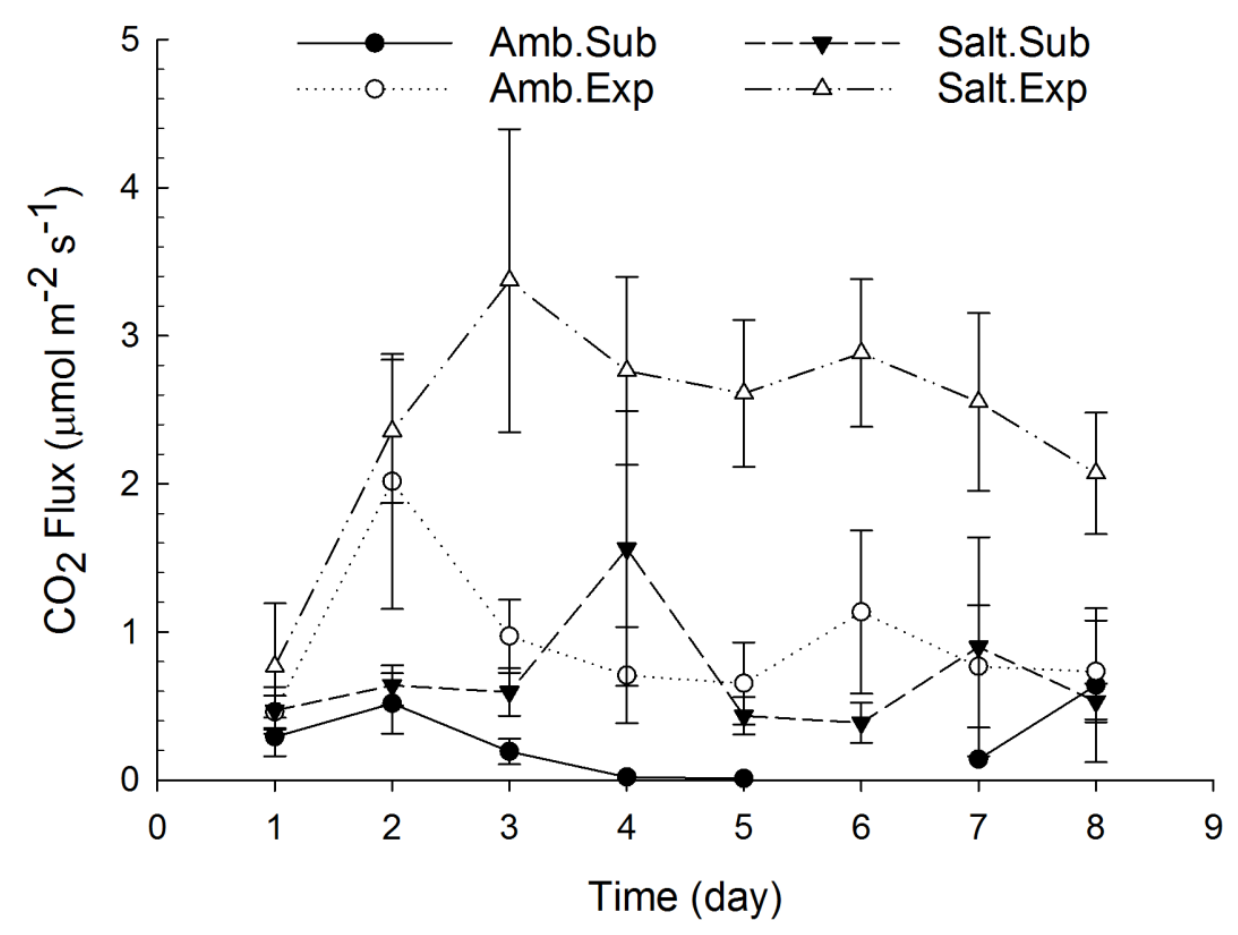

Figure 2. Daily soil $\mathrm{CO}_{2}$ efflux during the 8-day "ramp-up" period of the soil-only experiment in which salinity was raised by $\sim 1$ ppt every day in the elevated salinity monoliths from an ambient salinity of 10 to an elevated salinity of $20 \mathrm{ppt}$. Salinity in the ambient salinity tanks remained relatively constant during this same period. Points represent the mean $(n=6$ replicates $) \pm 1 \mathrm{SE}$. Amb $=$ Ambient salinity, Salt $=$ Elevated Salinity, Sub $=$ Submerged, Exp $=$ Exposed. 

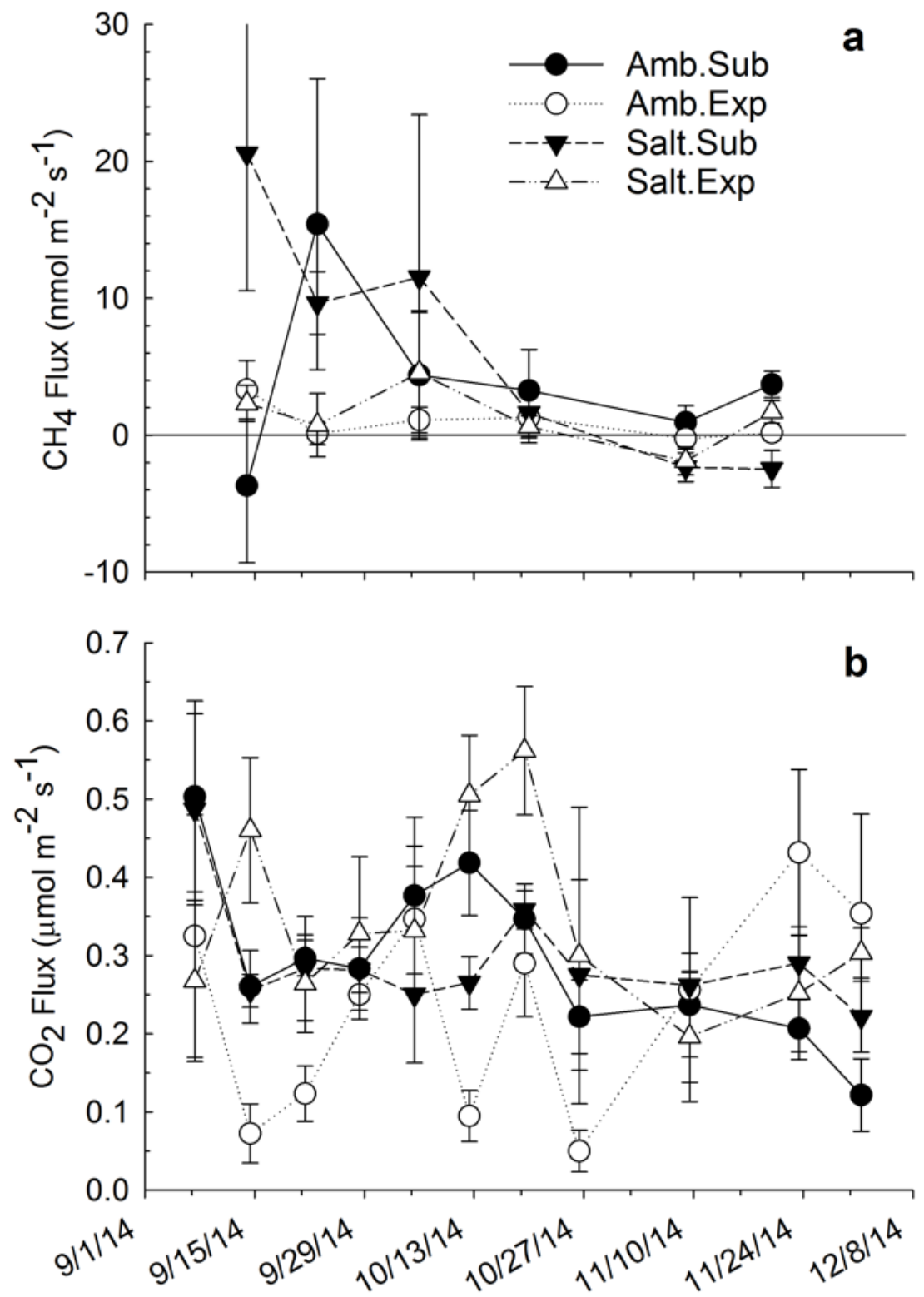

Figure 3. Soil $\mathrm{CH}_{4}$ ( $n=4$ replicates) and $\mathrm{CO}_{2}$ efflux ( $n=6$ replicates) over time for the soil-only experiment. Points represent means $\pm 1 \mathrm{SE}$. Amb $=$ Ambient salinity, Salt $=$ Elevated Salinity, Sub $=$ Submerged, Exp $=$ Exposed 

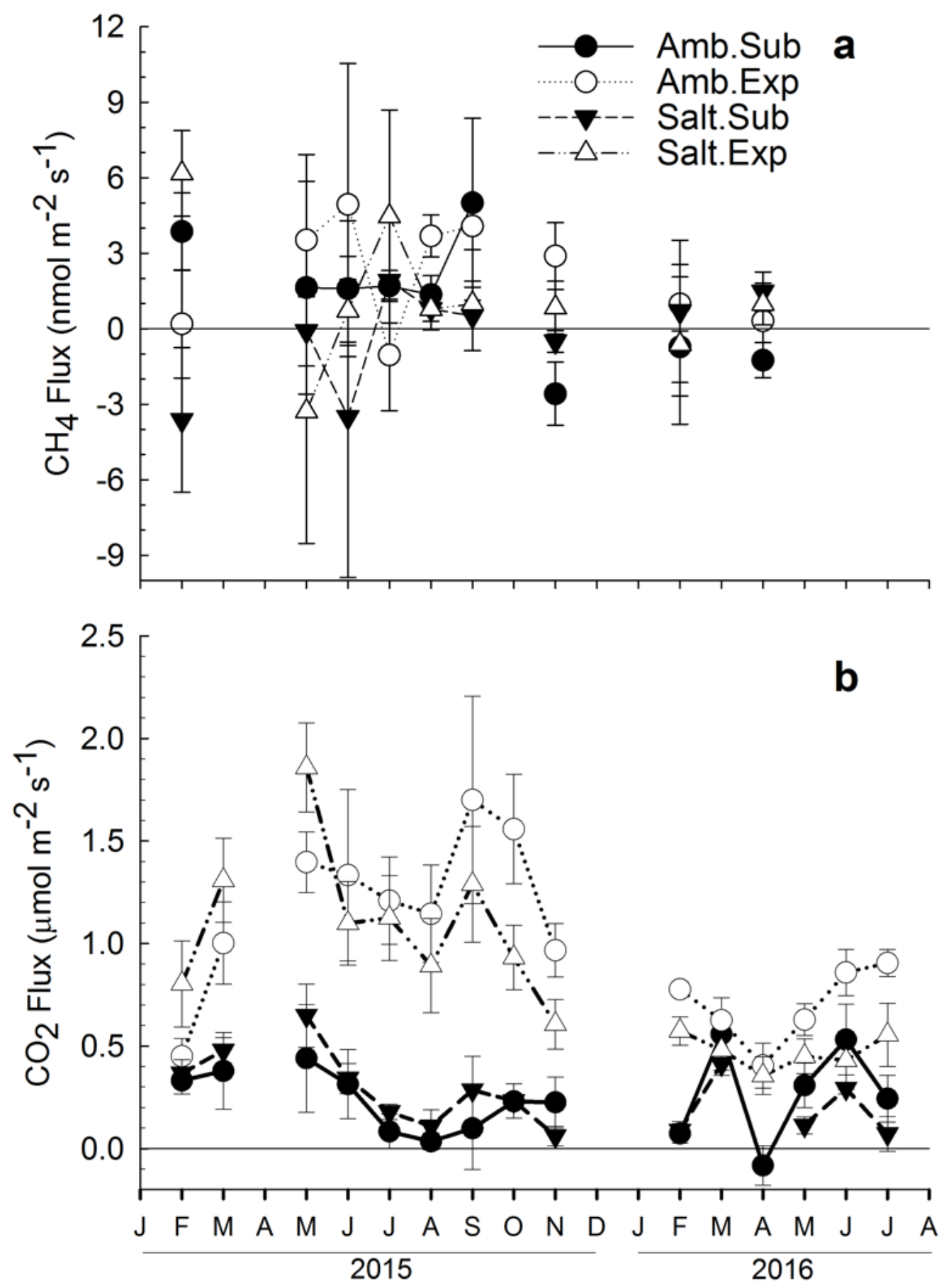

Figure 4. Soil $\mathrm{CH}_{4}$ ( $n=4$ replicates) and $\mathrm{CO}_{2}$ efflux ( $n=6$ replicates) over time for the plant-soil experiment. Points represent mean $\pm 1 \mathrm{SE}$. Amb $=$ Ambient salinity, Salt $=$ Elevated Salinity, Sub $=$ Submerged, Exp $=$ Exposed. 

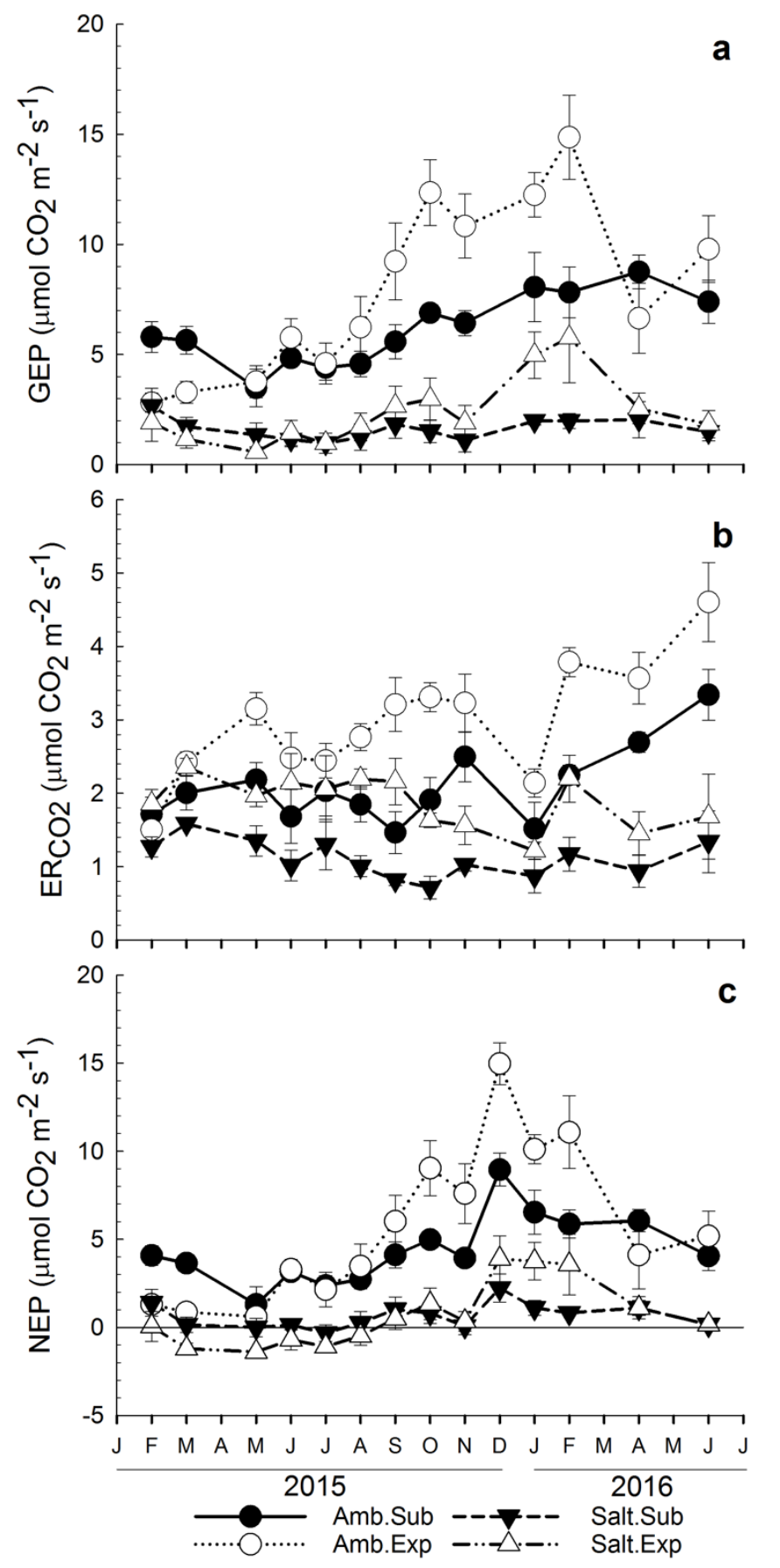

Figure 5. Monthly instantaneous gross ecosystem productivity (GEP) (a), ecosystem respiration of $\mathrm{CO}_{2}\left(\mathrm{ER}_{\mathrm{CO} 2}\right)(\mathrm{b})$, and net ecosystem productivity (NEP) (c) in micromoles of $\mathrm{CO}_{2}$ per meter squared per second over the experimental period for plant-soil experiment. A negative value indicates a flux of $\mathrm{CO}_{2}$ from the marsh to the atmosphere. Points represent means $(n=6$ replicates $) \pm 1 \mathrm{SE} . \mathrm{Amb}=$ Ambient salinity, Salt $=$ Elevated Salinity, Sub $=$ Submerged, Exp $=$ Exposed. 


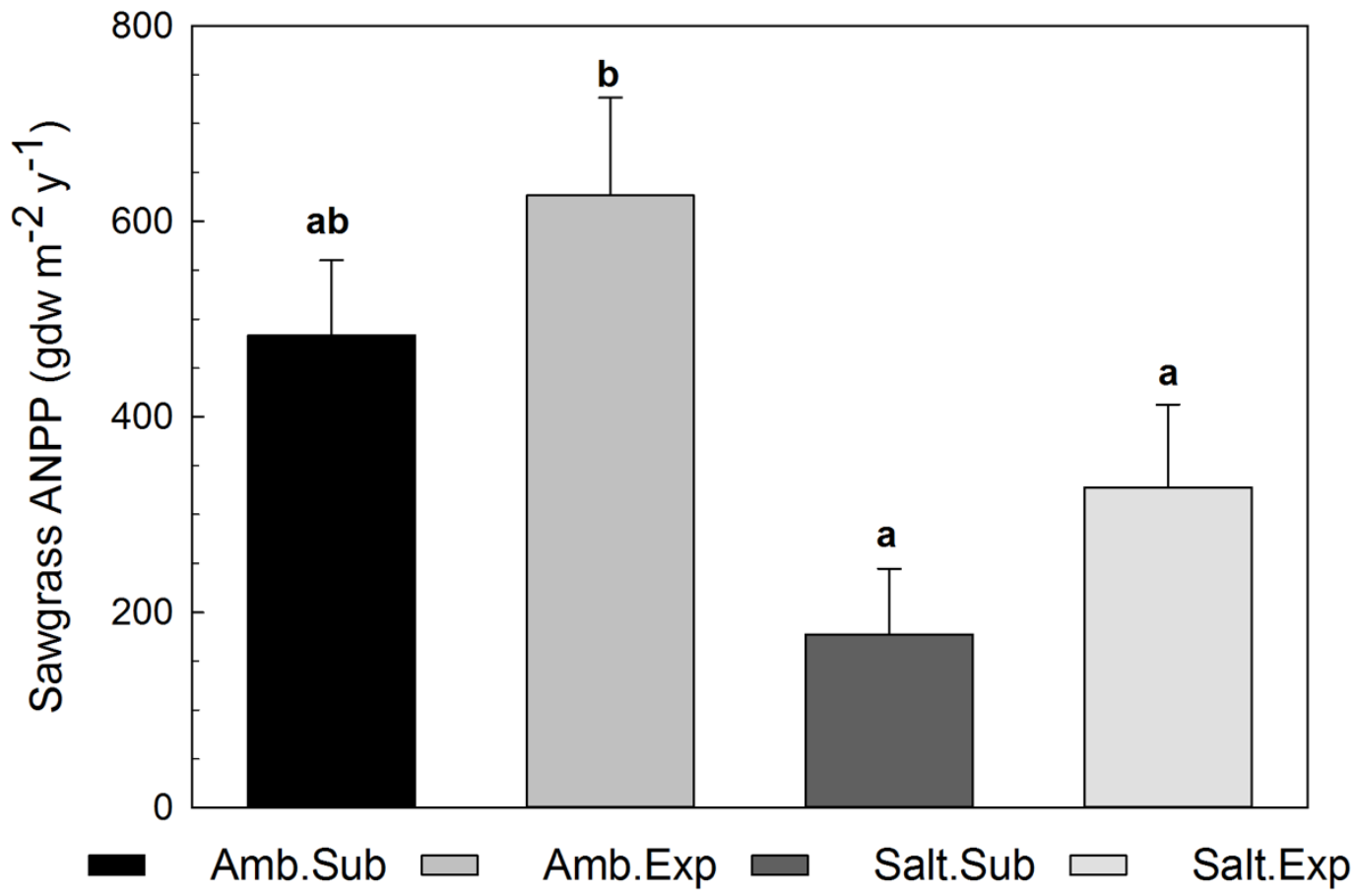

Figure 6. Mean $(n=6) \pm 1$ standard error of Cladium jamaicense (sawgrass) aboveground net primary productivity (ANPP) across the four treatments. Amb = Ambient salinity, Salt $=$ Elevated Salinity, $\mathrm{Sub}=$ Submerged, Exp $=$ Exposed. 


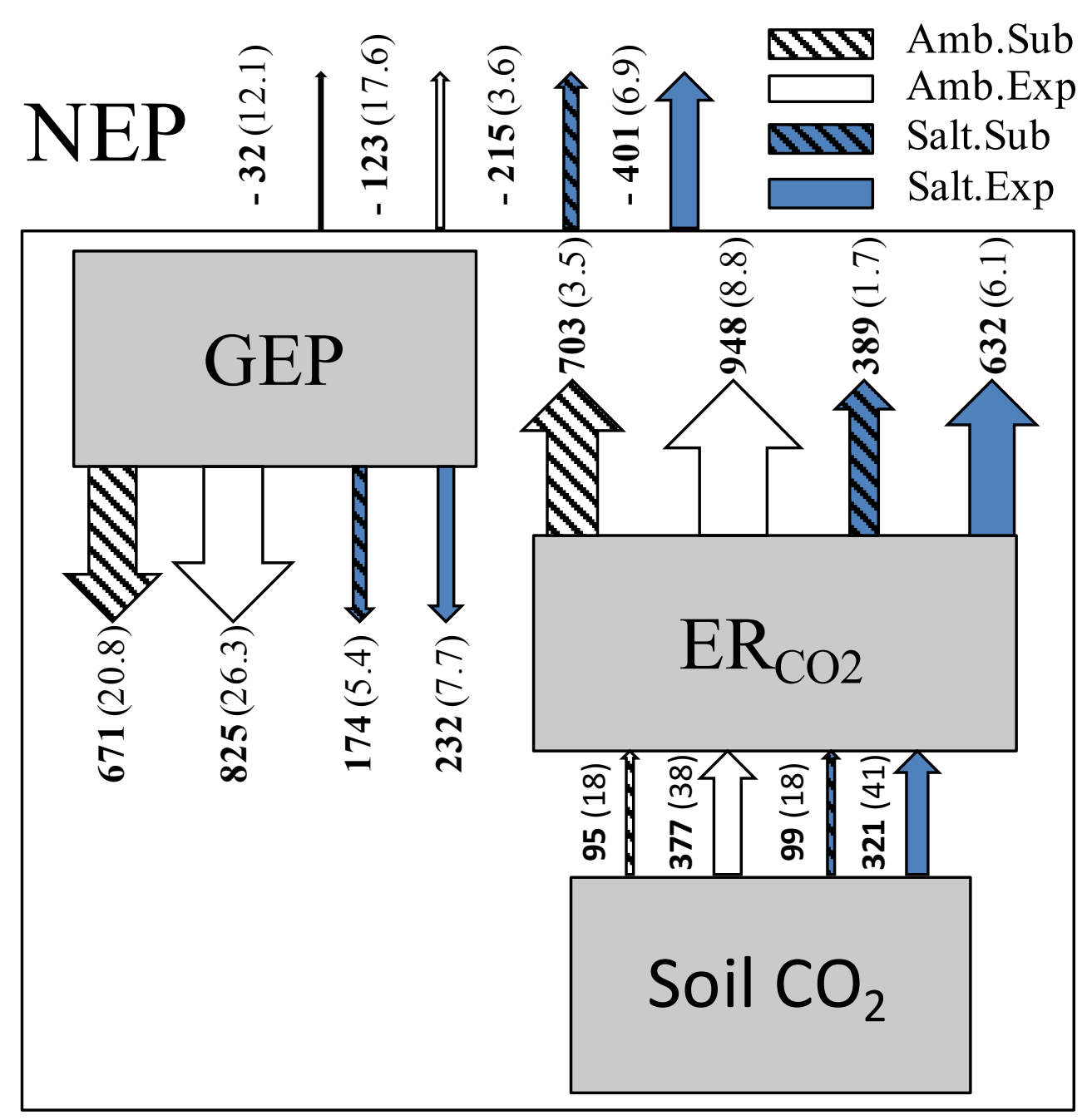

Figure 7. Schematic of estimated ecosystem $\mathrm{C}$ cycling for net ecosystem productivity (NEP), gross ecosystem productivity (GEP), ecosystem respiration of $\mathrm{CO}_{2}\left(\mathrm{ER}_{\mathrm{CO} 2}\right)$, and soil $\mathrm{CO}_{2}$ efflux from the plant-soil experiment and how it changes with elevated salinity and/or water depth. Arrows pointing down indicate $\mathrm{C}$ entering the marsh, while upward pointing arrows indicate $\mathrm{C}$ leaving the marsh to the atmosphere. Values represent mean $(n=6) \pm 1$ SE flux over the experimental timeframe in $\mathrm{g} \mathrm{C} \mathrm{m}^{-2} \mathrm{y}^{-1}$, and the width of the arrows is scaled to the overall flux. Annual flux was calculated using established methods and previously derived light response curves for a $C$. jamaicense brackish water marsh (Neubauer, 2013; Wilson et al., 2015). Amb = Ambient salinity (10 ppt), Salt = Elevated salinity $(20 \mathrm{ppt}), \mathrm{Exp}=$ Soil surface exposed $4-\mathrm{cm}, \mathrm{Sub}=$ Soil surface submerged. 


\section{SUPPLEMENTAL INFORMATION}

Table S1. Temperature, salinity, $\mathrm{pH}$, and dissolved surface water constituents averaged across all monoliths and the experimental duration for both the soil-only and plant-soil experiments $(n=6)$. DOC, $\mathrm{NH}_{4}^{+}$, TDN, and $\mathrm{SO}_{4}{ }^{2-}$ are in $\mathrm{mg} \mathrm{L}^{-1}, \mathrm{HS}^{-}$is in mM, and TDP and SRP are $\mu \mathrm{M} \mathrm{L}^{-1}$. Error is given as \pm 1 standard error

\begin{tabular}{|c|c|c|c|c|c|c|c|c|c|}
\hline & & \multicolumn{4}{|c|}{ 3-mo Means (Sep to Dec) } & \multicolumn{4}{|c|}{ 18-mo means } \\
\hline & & $\begin{array}{l}\text { Freshwater } \\
\text { source }\end{array}$ & $\begin{array}{l}\text { Saltwater } \\
\text { source }\end{array}$ & $\begin{array}{l}\text { Ambient } \\
\text { surface } \\
\text { water }\end{array}$ & $\begin{array}{l}\text { Elevated } \\
\text { surface } \\
\text { water }\end{array}$ & $\begin{array}{l}\text { Freshwater } \\
\text { source }\end{array}$ & $\begin{array}{l}\text { Saltwater } \\
\text { source }\end{array}$ & $\begin{array}{l}\text { Ambient } \\
\text { surface } \\
\text { water }\end{array}$ & $\begin{array}{l}\text { Elevated } \\
\text { surface } \\
\text { water }\end{array}$ \\
\hline \multirow[t]{2}{*}{ Temp } & Soil-Only & $25.9 \pm 3.0$ & $25.4 \pm 3.1$ & $25.8 \pm 4.0$ & $25.9 \pm 3.9$ & & & & \\
\hline & Plant-Soil & NA & NA & $28.5 \pm 1.2$ & $28.9 \pm 1.5$ & $27.9 \pm 0.8$ & $27.9 \pm 0.8$ & $27.6 \pm 1$ & $27.8 \pm 1.1$ \\
\hline \multirow[t]{2}{*}{ Salinity } & Soil-Only & $0.4 \pm 0.2$ & $37.7 \pm 1.5$ & $10.3 \pm 0.2$ & $20.5 \pm 0.8$ & & & & \\
\hline & Plant-Soil & NA & NA & $9.6 \pm 0.7$ & $19.5 \pm 0.7$ & $0.5 \pm 0.1$ & $36.9 \pm 1.7$ & $9.6 \pm 0.3$ & $19.2 \pm 0.5$ \\
\hline \multirow[t]{2}{*}{$\mathbf{p H}$} & Soil-Only & $8.07 \pm 0.23$ & $7.85 \pm 0.22$ & $8.03 \pm 0.38$ & $7.96 \pm 0.13$ & & & & \\
\hline & Plant-Soil & NA & NA & $8.07 \pm 0.12$ & $8.24 \pm 0.11$ & $8.3 \pm 0.05$ & $8.03 \pm 0.08$ & $7.98 \pm 0.06$ & $8 \pm 0.06$ \\
\hline \multirow[t]{2}{*}{ SO42- } & Soil-Only & $9.0 \pm 0.3$ & $3065 \pm 97$ & $805 \pm 27$ & $1520 \pm 38$ & & & & \\
\hline & Plant-Soil & NA & NA & $634 \pm 69$ & $1206 \pm 164$ & $58 \pm 41$ & $2828 \pm 125$ & $629 \pm 37$ & $1302 \pm 75$ \\
\hline TDP & Soil-Only & $0.27 \pm 0.02$ & $0.56 \pm 0.04$ & $0.36 \pm 0.04$ & $0.29 \pm 0.03$ & & & & \\
\hline \multirow[t]{2}{*}{ SRP } & Soil-Only & $0.10 \pm 0.01$ & $0.02 \pm 0.01$ & $0.09 \pm 0.01$ & $0.05 \pm 0.01$ & & & & \\
\hline & Plant-Soil & $0.09 \pm 0.01$ & $0.04 \pm 0.01$ & $0.06 \pm 0.01$ & $0.05 \pm 0.01$ & $0.09 \pm 0.01$ & $0.04 \pm 0.01$ & $0.06 \pm 0.01$ & $0.05 \pm 0.01$ \\
\hline DOC & Plant-Soil & $10.2 \pm 0.7$ & $9.7 \pm 0.6$ & $14.9 \pm 0.7$ & $14.7 \pm 0.6$ & $10.2 \pm 0.7$ & $9.7 \pm 0.6$ & $14.9 \pm 0.7$ & $14.7 \pm 0.6$ \\
\hline NH4+ & Plant-Soil & $0.03 \pm 0.01$ & $0.03 \pm 0.00$ & $0.05 \pm 0.01$ & $0.04 \pm 0.00$ & $0.03 \pm 0.01$ & $0.03 \pm 0.00$ & $0.05 \pm 0.01$ & $0.04 \pm 0.00$ \\
\hline TDN & Plant-Soil & $0.59 \pm 0.03$ & $0.80 \pm 0.05$ & $0.96 \pm 0.04$ & $1.01 \pm 0.04$ & $0.59 \pm 0.03$ & $0.80 \pm 0.05$ & $0.96 \pm 0.04$ & $1.01 \pm 0.04$ \\
\hline
\end{tabular}


Table S2. Full statistical results of porewater chemistry for the linear mixed model run with time as an independent variable for both experiments. Interpreted results in bold. Data presented as $F$ (numerator degrees of freedom,denominator degrees of freedom) $=F$ value, $p=P$ value. $D O C$ dissolved organic carbon, $\mathrm{NH}_{4}{ }^{+}$ammonium, $T D N$ total dissolved nitrogen, $\mathrm{SO}_{4}{ }^{2-}$ sulfate, $\mathrm{TDP}$ total dissolved phosphorus, $S R P$ soluble reactive phosphorus, $H S$ sulfide

\begin{tabular}{|c|c|c|c|c|c|c|c|c|}
\hline $\begin{array}{l}\text { Experi- } \\
\text { ment }\end{array}$ & & Salinity & Inundation & Time & $\begin{array}{l}\text { Salinity* } \\
\text { Inundation }\end{array}$ & Salinity*Time & $\begin{array}{l}\text { Inundation* } \\
\text { Time }\end{array}$ & $\begin{array}{l}\text { Salinity* } \\
\text { Inundation* } \\
\text { Time }\end{array}$ \\
\hline \multirow[t]{7}{*}{$\begin{array}{l}\text { Soil } \\
\text { Only }\end{array}$} & $\mathrm{pH}$ & $\begin{array}{l}F(1,4)=6.82 \\
p=0.059\end{array}$ & $\begin{array}{l}F(1,4)=0.80 \\
p=0.421\end{array}$ & $\begin{array}{l}F(11,207)=17.28 \\
P<0.001\end{array}$ & $\begin{array}{l}F(1,4)=6.24 \\
p=0.066\end{array}$ & $\begin{array}{l}F(11,207)=0.50 \\
p=0.904\end{array}$ & $\begin{array}{l}F(11,207)=0.32 \\
p=0.981\end{array}$ & $\begin{array}{l}F(11,207)=0.78 \\
p=0.664\end{array}$ \\
\hline & DOC & $\begin{array}{l}F(1,4)=1.64 \\
p=0.200\end{array}$ & $\begin{array}{l}F(1,4)=2.00 \\
p=0.216\end{array}$ & $\begin{array}{l}F(11,221)=3.78 \\
P<0.001\end{array}$ & $\begin{array}{l}F(1,4)=3.19 \\
p=0.075\end{array}$ & $\begin{array}{l}F(11,221)=3.44 \\
P<0.001\end{array}$ & $\begin{array}{l}F(11,221)=1.18 \\
P=0.296\end{array}$ & $\begin{array}{l}F(11,221)=1.07 \\
p=0.384\end{array}$ \\
\hline & $\mathrm{NH}_{4}^{+}$ & $\begin{array}{l}F(1,4)=2.12 \\
p=0.146\end{array}$ & $\begin{array}{l}F(1,4)=3.12 \\
p=0.137\end{array}$ & $\begin{array}{l}F(11,221)=2.42 \\
p=0.007\end{array}$ & $\begin{array}{l}F(1,4)=3.31 \\
p=0.069\end{array}$ & $\begin{array}{l}F(11,221)=1.04 \\
p=0.411\end{array}$ & $\begin{array}{l}F(11,221)=0.63 \\
p=0.797\end{array}$ & $\begin{array}{l}F(11,221)=0.49 \\
p=0.906\end{array}$ \\
\hline & TDN & $\begin{array}{l}F(1,4)=0.45 \\
p=0.498\end{array}$ & $\begin{array}{l}F(1,4)=2.70 \\
p=0.160\end{array}$ & $\begin{array}{l}F(11,221)=8.69 \\
P<0.001\end{array}$ & $\begin{array}{l}F(1,4)=4.84 \\
p=0.028\end{array}$ & $\begin{array}{l}F(11,221)=1.83 \\
p=0.049\end{array}$ & $\begin{array}{l}F(11,221)=0.96 \\
p=0.476\end{array}$ & $\begin{array}{l}F(11,221)=0.78 \\
p=0.652\end{array}$ \\
\hline & $\mathrm{SO}_{4}{ }^{2-}$ & $\begin{array}{l}F(1,4)=5.42 \\
p=0.028\end{array}$ & $\begin{array}{l}F(1,4)=1.57 \\
p=0.264\end{array}$ & $\begin{array}{l}F(11,221)=21.12 \\
P<0.001\end{array}$ & $\begin{array}{l}F(1,4)=0.15 \\
p=0.691\end{array}$ & $\begin{array}{l}F(11,221)=5.54 \\
P<0.001\end{array}$ & $\begin{array}{l}F(11,221)=1.93 \\
p=0.035\end{array}$ & $\begin{array}{l}F(11,221)=0.84 \\
p=0.599\end{array}$ \\
\hline & TDP & $\begin{array}{l}F(1,4)=1.58 \\
p=0.276\end{array}$ & $\begin{array}{l}F(1,4)=5.54 \\
p=0.079\end{array}$ & $\begin{array}{l}F(2,52)=0.81 \\
p=0.447\end{array}$ & $\begin{array}{l}F(1,4)=0.50 \\
p=0.517\end{array}$ & $\begin{array}{l}F(2,52)=0.56 \\
p=0.571\end{array}$ & $\begin{array}{l}F(2,52)=0.28 \\
p=0.750\end{array}$ & $\begin{array}{l}F(2,52)=0.05 \\
p=0.964\end{array}$ \\
\hline & SRP & $\begin{array}{l}F(1,4)=10.18 \\
P=0.033\end{array}$ & $\begin{array}{l}F(1,4)=6.24 \\
p=0.066\end{array}$ & $\begin{array}{l}F(2,52)=2.61 \\
p=0.082\end{array}$ & $\begin{array}{l}F(1,4)=0.25 \\
p=0.640\end{array}$ & $\begin{array}{l}F(2,52)=0.54 \\
p=0.581\end{array}$ & $\begin{array}{l}F(2,52)=0.06 \\
p=0.933\end{array}$ & $\begin{array}{l}F(2,52)=0.43 \\
p=0.648\end{array}$ \\
\hline \multirow[t]{9}{*}{$\begin{array}{l}\text { Plant- } \\
\text { Soil }\end{array}$} & $\mathrm{pH}$ & $\begin{array}{l}F(1,4)=0.12 \\
p=0.747\end{array}$ & $\begin{array}{l}F(1,4)=0.04 \\
p=0.860\end{array}$ & $\begin{array}{l}F(17,338)=21.92 \\
P<0.001\end{array}$ & $\begin{array}{l}F(1,4)=0.23 \\
p=0.657\end{array}$ & $\begin{array}{l}F(17,338)=0.54 \\
p=0.932\end{array}$ & $\begin{array}{l}F(17,338)=0.55 \\
p=0.924\end{array}$ & $\begin{array}{l}F(17,338)=0.46 \\
p=0.970\end{array}$ \\
\hline & DOC & $\begin{array}{l}F(1,4)=0.13 \\
p=0.732\end{array}$ & $\begin{array}{l}F(1,4)=1.40 \\
p=0.301\end{array}$ & $\begin{array}{l}F(17,340)=18.64 \\
P<0.001\end{array}$ & $\begin{array}{l}F(1,4)=1.47 \\
p=0.291\end{array}$ & $\begin{array}{l}F(17,340)=0.69 \\
p=0.810\end{array}$ & $\begin{array}{l}F(17,340)=0.65 \\
p=0.845\end{array}$ & $\begin{array}{l}F(17,340)=0.30 \\
p=0.996\end{array}$ \\
\hline & $\mathrm{NH}_{4}^{+}$ & $\begin{array}{l}F(1,4)=0.37 \\
p=0.574\end{array}$ & $\begin{array}{l}F(1,4)=0.07 \\
p=0.794\end{array}$ & $\begin{array}{l}F(17,340)=7.73 \\
P<0.001\end{array}$ & $\begin{array}{l}F(1,4)=0.90 \\
p=0.395\end{array}$ & $\begin{array}{l}F(17,340)=1.37 \\
p=0.144\end{array}$ & $\begin{array}{l}F(17,340)=0.74 \\
p=0.758\end{array}$ & $\begin{array}{l}F(17,340)=0.27 \\
p=0.998\end{array}$ \\
\hline & TDN & $\begin{array}{l}F(1,4)=0.31 \\
p=0.606\end{array}$ & $\begin{array}{l}F(1,4)=0.14 \\
p=0.725\end{array}$ & $\begin{array}{l}F(17,340)=15.84 \\
P<0.001\end{array}$ & $\begin{array}{l}F(1,4)=1.13 \\
p=0.346\end{array}$ & $\begin{array}{l}F(17,340)=1.34 \\
p=0.346\end{array}$ & $\begin{array}{l}F(17,340)=0.75 \\
p=0.741\end{array}$ & $\begin{array}{l}F(17,340)=0.81 \\
p=0.674\end{array}$ \\
\hline & $\mathrm{SO}_{4}{ }^{2-}$ & $\begin{array}{l}F(1,4)=204.97 \\
P<0.001\end{array}$ & $\begin{array}{l}F(1,4)=0.00 \\
p=0.940\end{array}$ & $\begin{array}{l}F(17,333)=42.98 \\
P<0.001\end{array}$ & $\begin{array}{l}F(1,4)=1.50 \\
p=0.286\end{array}$ & $\begin{array}{l}F(17,333)=6.27 \\
P<0.001\end{array}$ & $\begin{array}{l}F(17,333)=0.44 \\
p=0.974\end{array}$ & $\begin{array}{l}F(17,333)=1.15 \\
p=0.297\end{array}$ \\
\hline & TDP & $\begin{array}{l}F(1,4)=0.00 \\
p=0.980\end{array}$ & $\begin{array}{l}F(1,4)=0.43 \\
p=0.545\end{array}$ & $\begin{array}{l}F(16,319)=5.66 \\
P<0.001\end{array}$ & $\begin{array}{l}F(1,4)=1.26 \\
p=0.323\end{array}$ & $\begin{array}{l}F(16,319)=1.38 \\
p=0.147\end{array}$ & $\begin{array}{l}F(16,319)=0.50 \\
p=0.945\end{array}$ & $\begin{array}{l}F(16,319)=0.68 \\
p=0.804\end{array}$ \\
\hline & SRP & $\begin{array}{l}F(1,4)=0.09 \\
p=0.776\end{array}$ & $\begin{array}{l}F(1,4)=0.44 \\
p=0.539\end{array}$ & $\begin{array}{l}F(16,278)=6.00 \\
P<0.001\end{array}$ & $\begin{array}{l}F(1,4)=0.80 \\
p=0.420\end{array}$ & $\begin{array}{l}F(16,278)=0.93 \\
p=0.531\end{array}$ & $\begin{array}{l}F(16,278)=0.16 \\
p=0.999\end{array}$ & $\begin{array}{l}F(16,278)=0.74 \\
p=0.742\end{array}$ \\
\hline & $\mathrm{HS}^{-}$ & $\begin{array}{l}F(1,4)=0.27 \\
p=0.628\end{array}$ & $\begin{array}{l}F(1,4)=0.00 \\
p=0.944\end{array}$ & $\begin{array}{l}F(12,237)=30.56 \\
P<0.001\end{array}$ & $\begin{array}{l}F(1,4)=0.27 \\
p=0.628\end{array}$ & $\begin{array}{l}F(12,237)=1.74 \\
p=0.058\end{array}$ & $\begin{array}{l}F(12,237)=0.20 \\
p=0.998\end{array}$ & $\begin{array}{l}F(12,237)=0.32 \\
p=0.985\end{array}$ \\
\hline & Redox & $\begin{array}{l}F(1,4)=0.18 \\
p=0.689\end{array}$ & $\begin{array}{l}F(1,4)=2.82 \\
p=0.168\end{array}$ & $\begin{array}{l}F(14,286)=43.25 \\
P<0.001\end{array}$ & $\begin{array}{l}F(1,4)=6.16 \\
p=0.068\end{array}$ & $\begin{array}{l}F(14,286)=1.24 \\
p=0.242\end{array}$ & $\begin{array}{l}F(14,286)=1.57 \\
p=0.084\end{array}$ & $\begin{array}{l}F(14,286)=1.24 \\
p=0.241\end{array}$ \\
\hline
\end{tabular}


Table S3. Full statistical results for the linear mixed model run with experiment as an independent variable for all parameters measured in both experiments. Results with $\alpha<0.05$ are in bold. Data presented as $F$ (numerator degrees of freedom,denominator degrees of freedom) $=F$ value, $p=P$ value.

$D O C$ dissolved organic carbon, $\mathrm{NH}_{4}^{+}$ammonium, $T D N$ total dissolved nitrogen, $\mathrm{SO}_{4}{ }^{2-}$ sulfate, $\mathrm{TDP}$ total dissolved phosphorus, $S R P$ soluble reactive phosphorus, $H S$ sulfide

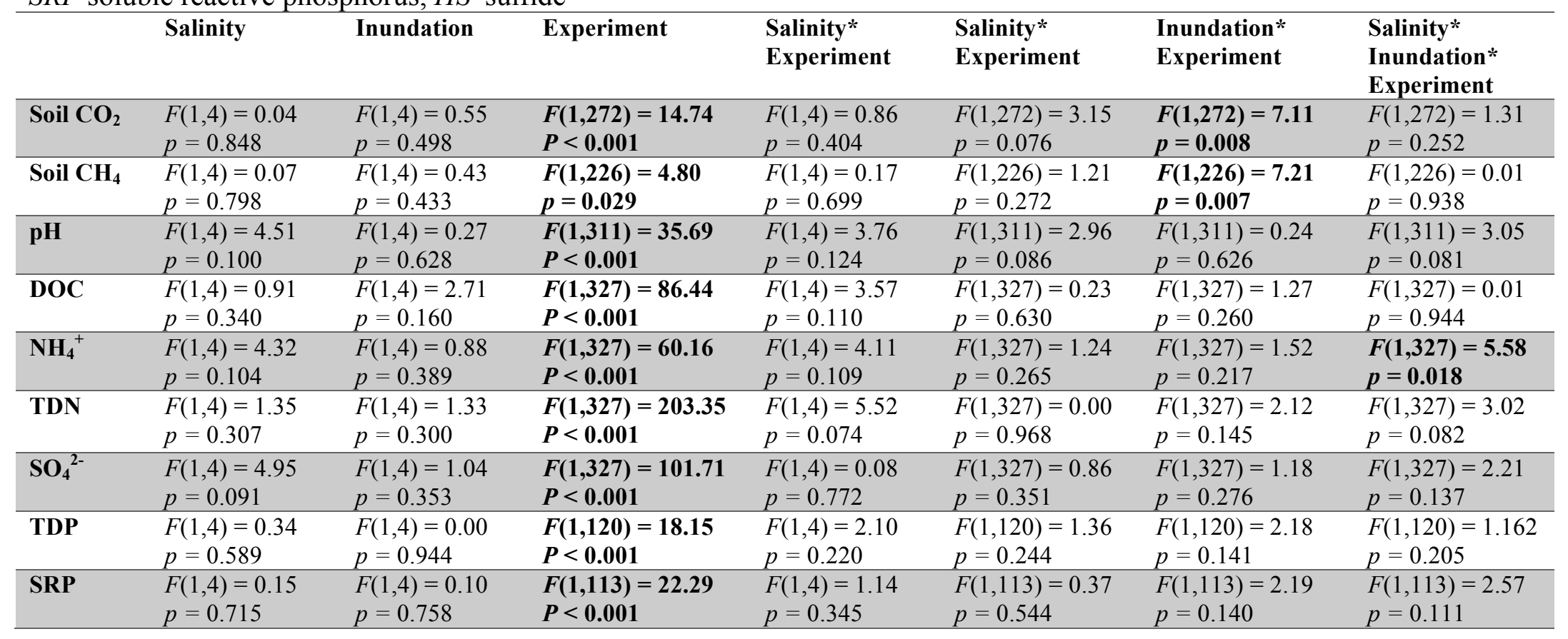




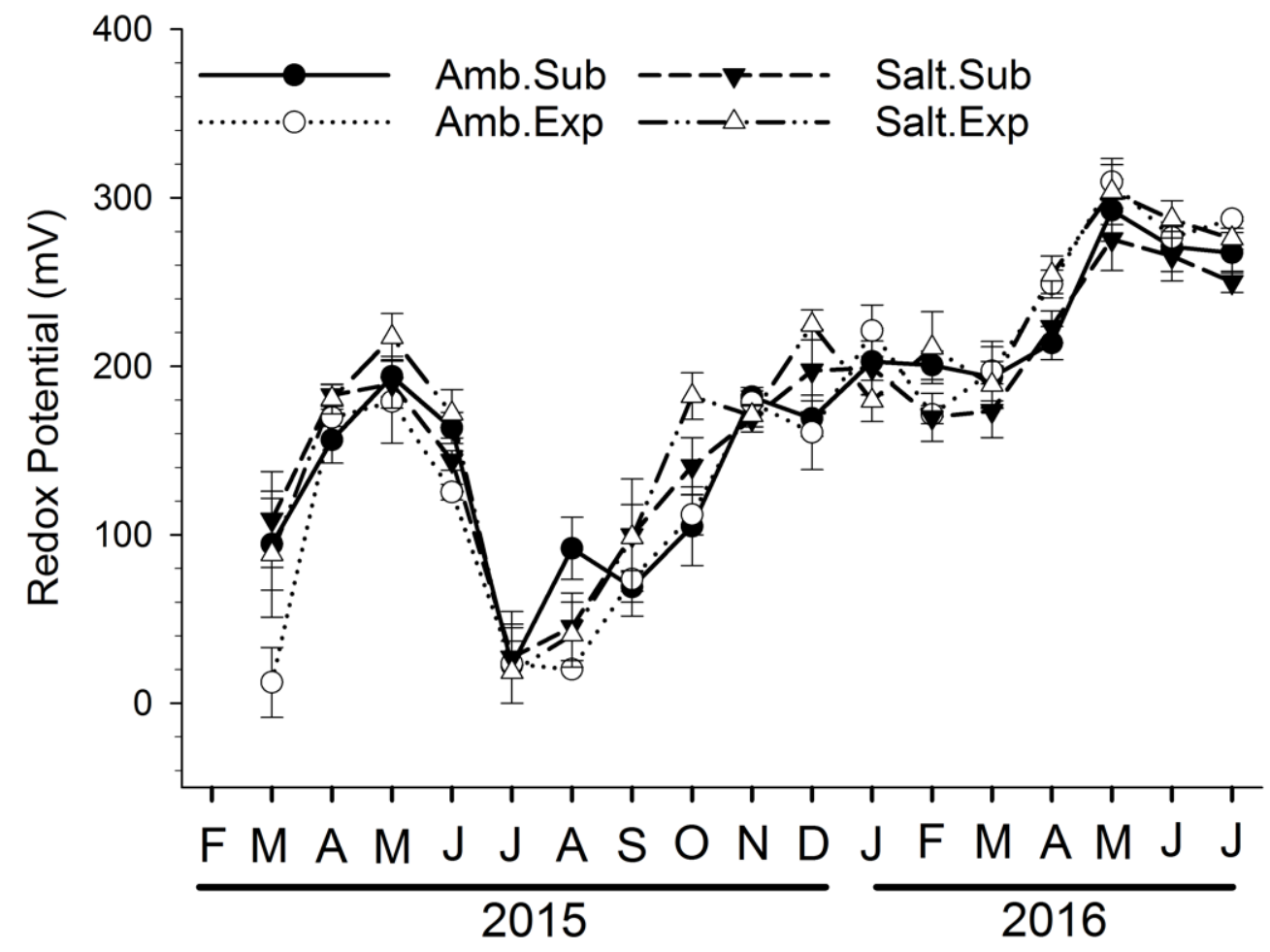

Fig S1. Redox potential for each treatment measured monthly at 5-cm depth over the duration of the experiment. Points represent the mean $(n=6) \pm 1$ standard error. 


\section{CHAPTER IV}

SALTWATER INTRUSION AND DROUGHT DRIVE PEAT COLLAPSE IN A COASTAL PEATLAND 
Saltwater intrusion and drought drive peat collapse in a coastal peatland

Authors: Benjamin J. Wilson ${ }^{1}$, Tiffany G. Troxler ${ }^{1}$, Sean Charles ${ }^{1}$, Shelby Servais ${ }^{1}$, Viviana Mazzei ${ }^{1}$, Stephen E. Davis ${ }^{2}$, Evelyn Gaiser ${ }^{1}$, John S. Kominoski ${ }^{1}$, Jennifer Richards ${ }^{1}$, David Rudnick ${ }^{4}$, and Fred Sklar ${ }^{3}$

${ }^{1}$ Florida International University, Dept. of Biological Sciences and Southeast

Environmental Research Center, Miami, FL 33199

${ }^{2}$ Everglades Foundation, Palmetto Bay, FL 33157

${ }^{3}$ South Florida Water Management District, West Palm Beach, FL 33406

${ }^{4}$ Everglades National Park, Homestead, FL 33034 


\begin{abstract}
Climate change threatens globally important carbon stores found in coastal peatlands. Sea level rise and drought intensify saltwater intrusion which elevates salinity and triggers biogeochemical changes that affect wetland carbon storage. However, little work has been done investigating the combined effects of elevated salinity and drought in coastal peatlands. Here, we combined long-term mesocosm experiments and in situ field measurements in brackish peatlands to examine the impact of elevated salinity and drought on carbon loss in the Florida Everglades. In our mesocosm experiment, elevated salinity reduced gross ecosystem productivity and belowground root growth, while drought stimulated organic matter mineralization and carbon dioxide loss from the marsh. Soil elevation declined $\sim 2.9 \mathrm{~cm}$ in one year under brackish water conditions and by $\sim 4.4$ cm when elevated salinity was coupled with drought. Results from our field research revealed seasonal dry-down patterns which led to increased porewater salinity concentration. We suggest that saltwater intrusion initially destabilizes peat soils by reducing organic matter inputs and that seasonal dry-down exacerbates peat collapse.
\end{abstract}

\title{
MAIN
}

Although peatlands occupy only $\sim 3 \%$ of the Earth's surface, they store $15-30 \%$ of the world's soil carbon (C) as peat ${ }^{1}$. In most peatlands, hydrology drives the flow of C through the ecosystem ${ }^{2}$. Under waterlogged conditions, production outpaces decomposition and $\mathrm{C}$ accumulates in soils over millennia. However, a shift in hydrology towards drier conditions, caused by either drought or drainage, can cause extensive vegetation dieback ${ }^{3}$ and large amounts of stored $\mathrm{C}$ to be released to the atmosphere 
through enhanced decomposition and can shift the ecosystem from a net $\mathrm{C}$ sink to a $\mathrm{C}$ source $^{4-6}$. As stored C effluxes to the atmosphere, degradation of the soil structure can lead to a loss of soil elevation and even a sudden (within a year) collapse of the peat ${ }^{7}$. Although the effects of drought on temperate inland peat soil C have been well studied ${ }^{4-}$ ${ }^{6,8}$, less is known about coastal peatlands ${ }^{9,10}$

The Everglades is the largest subtropical peatland in the world and has accumulated peat soils for the past $\sim 5,000$ years ${ }^{11}$. However, modification and compartmentalization of the landscape in the early to mid-1900s shifted water flows away from the southern coastal Everglades, leaving the area vulnerable not only to drought but also to more saltwater intrusion. Saltwater intrusion into coastal wetlands has been shown to strongly change ecosystem $\mathrm{C}$ cycling ${ }^{12-17}$. In coastal peatlands, elevated salinity can lead to decreased plant production and gross ecosystem productivity ${ }^{18,19}$, which in turn decreases organic matter inputs to the soil through declines in root productivity and biomass ${ }^{20}$, switches the marsh from an annual net $\mathrm{C}$ sink to a net $\mathrm{C}$ source $^{18,19}$, and destabilizes peat, leaving it vulnerable to collapse ${ }^{21,22}$. Peat collapse has been observed in numerous coastal peatlands ${ }^{7,21,23}$, including the Everglades (Fig. 1). In mangrove systems, peat collapse has been attributed to tree death following hurricanes ${ }^{7}$. In inland marshes, saltwater intrusion is hypothesized to be the driving force behind peat collapse $^{18,19,23,24}$; however, it is unclear how saltwater intrusion interacts with seasonal hydrology and drought to influence peat collapse.

Previous work has shown that elevated salinity pulses in a brackish peatland did not affect net ecosystem productivity (NEP) when water covered the soil surface; however, when water fell below the soil surface, as in periods of prolonged drought, 
elevated salinity enhanced $\mathrm{CO}_{2}$ loss from the peatland ${ }^{19}$. We conducted an experiment to mimic this coupled saltwater intrusion and drought event in a controlled mesocosm setting to determine how salinity and drought interact to affect the net ecosystem C balance (NECB). We harvested plant-peat soil monoliths from a brackish marsh in Everglades National Park, FL, USA and conducted a year-long mesocosm experiment in which monoliths were subjected to either ambient (10 ppt) or elevated (20 ppt) salinity coupled with a drought treatment (continually inundated or seasonal dry-down; Supplementary Table S1). We measured changes in the NECB which included measurements of $\mathrm{CO}_{2}$ gas exchange, aboveground and root productivity, root and litter decomposition, and soil elevation change. 


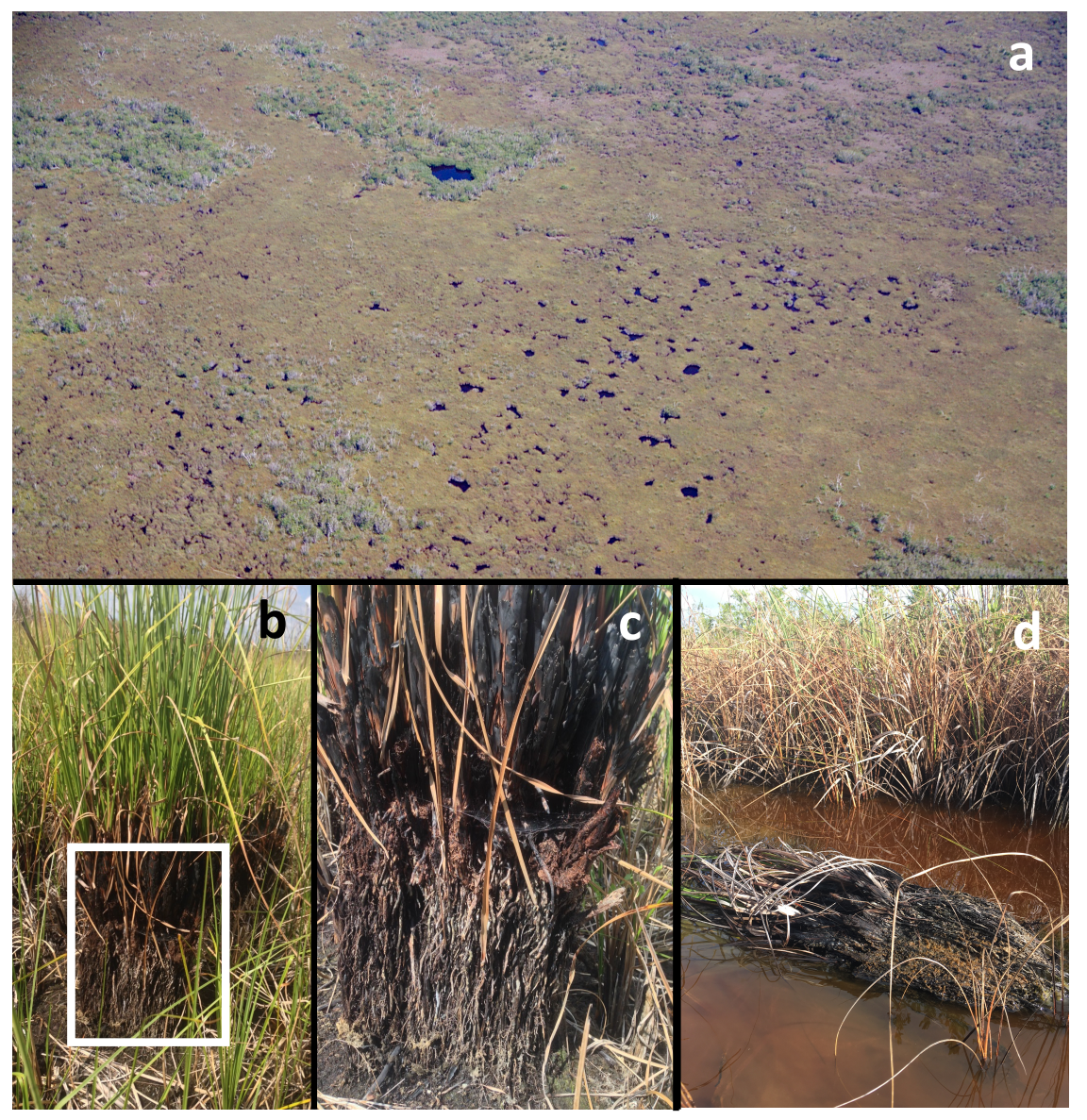

Figure 1. Photos showing peat collapse in the coastal Everglades $5 \mathrm{~km}$ inland. a, aerial photography showing open water ponds dotting the landscape. $\mathbf{b}$, a group of sawgrass culms at ground level within this marsh. c, zoomed-in portion of photo b showing the delineation between the bottom of the culms and exposed roots. d, a recently collapsed sawgrass pedestal. Photo credits: a, S.E.D.; b-d, B.J.W.

The balance between productivity and decomposition controls peat accretion and stability in peatlands that do not have an external supply of sediments ${ }^{25-27}$. Elevated salinity in coastal wetlands can significantly influence soil C inputs by stressing vegetation and decreasing productivity ${ }^{15,28}$. We found that elevated salinity reduced GEP $(P=0.064)$ and aboveground biomass $(P=0.001)$ in both inundated and exposed monoliths (Table S2). A reduction in GEP with elevated salinity subsequently led to a significant 
reduction in root production of $83 \pm 38 \%$ and $85 \pm 24 \%$ in the submerged and drought treatments, respectively (Table 1). Root growth and aboveground biomass turnover are the dominant forms of organic matter inputs into coastal peat marshes and contribute the most to vertical accretion ${ }^{27}$. A decline in these organic matter sources can lead to reduced soil accretion rates and compromise the integrity of peat soils ${ }^{7,18}$. Delaune et al. (1994) hypothesized that peat collapse in a brackish Louisiana marsh was caused by the loss of live roots and their turgor pressure when exposed to elevated salinity; as roots lose turgor pressure, large air spaces within the roots may collapse. 
Table 1. Net ecosystem carbon balance of a brackish water marsh.

\begin{tabular}{|c|c|c|c|c|c|c|c|c|}
\hline Treatment & NEP & GEP & $\mathbf{E R}_{\mathrm{CO} 2}$ & $\mathrm{Soil} \mathrm{CO}_{2}$ & ANPP & $\begin{array}{r}\text { Root } \\
\text { ingrowth }\end{array}$ & $\begin{array}{r}\text { Root } \\
\text { Decomp }\end{array}$ & $\begin{array}{r}\text { Leaf } \\
\text { Decomp }\end{array}$ \\
\hline Amb.Sub & $-136 \pm 70$ & $585 \pm 115$ & $-721 \pm 25$ & $-161 \pm 23$ & $265 \pm 36$ & $94 \pm 22$ & $-80 \pm 6$ & $-38 \pm 3$ \\
\hline Amb.Exp & $-698 \pm 127$ & $953 \pm 189$ & $-1651 \pm 64$ & $-385 \pm 66$ & $275 \pm 65$ & $106 \pm 15$ & $-72 \pm 9$ & $-27 \pm 1$ \\
\hline Salt.Sub & $-322 \pm 41$ & $279 \pm 55$ & $-602 \pm 28$ & $-251 \pm 80$ & $189 \pm 34$ & $16 \pm 8$ & $-52 \pm 5$ & $-33 \pm 2$ \\
\hline Salt.Exp & $-633 \pm 67$ & $298 \pm 58$ & $-931 \pm 77$ & $-414 \pm 73$ & $247 \pm 42$ & $15 \pm 5$ & $-65 \pm 8$ & $-20 \pm 1$ \\
\hline
\end{tabular}

Mean $\pm 1 \mathrm{SE}$ of the net annual ecosystem carbon (C) balance $\left(\mathrm{g} \mathrm{C} \mathrm{m}^{-2} \mathrm{yr}^{-1}\right)$ for a brackish water marsh. A positive number indicates an input of $\mathrm{C}$ to the marsh, while a negative number indicates a net output of $\mathrm{C}$ from the marsh. Statistical information regarding the influence of elevated salinity, drought, and their combined effects can be found in Table S2. Amb = Ambient salinity, Salt $=$ Elevated Salinity, Sub $=$ Submerged, Exp $=$ Exposed.

$n=4$ for NEP, GEP, ER $\mathrm{CO}_{2} ; n=6$ for Soil $\mathrm{CO}_{2}$, ANPP, Root ingrowth, Root Decomp, and Leaf Decomp.

$N E P$ net ecosystem productivity, GEP gross ecosystem productivity, $E R_{C O 2}$ ecosystem respiration of $\mathrm{CO}_{2}, A N P P$ aboveground net primary productivity, Decomp decomposition 
Soil $\mathrm{CO}_{2}$ efflux responded differently to elevated salinity over short- and longterms (Supplemental Fig. S1). Two weeks after raising salinity from $\sim 10$ to $15 \mathrm{ppt}$, there was a significant spike in soil $\mathrm{CO}_{2}$ efflux from the elevated salinity treatments $(P=0.014)$. However, this response diminished as salinity was raised from $\sim 15$ to $20 \mathrm{ppt}$ with no overall difference in soil $\mathrm{CO}_{2}$ efflux with elevated salinity for the duration of the experiment (Table 1, $P=0.509$ ). Results documenting changes in wetland organic matter mineralization with saltwater intrusion have been mixed, with some studies showing long-term acceleration ${ }^{13}$, short-term acceleration ${ }^{29}$, and deceleration ${ }^{15}$ (this study), though the effect is dependent on the salinity concentration and duration of exposure. With exposure to a wide range of salinities, A recent study found that there are thresholds for greenhouse gas production in tidal freshwater wetlands, with moderate amounts of elevated salinity (5-7.5 ppt) stimulating soil $\mathrm{CO}_{2}$ efflux and higher concentrations ( $>15$ ppt) reducing it $^{30}$.

Drought, and the subsequent dry-down of water below the soil surface, has been shown to have strong effects on ecosystem $\mathrm{C}$ cycling in wetlands as soil oxidation accelerates organic matter breakdown and soil $\mathrm{CO}_{2}$ efflux to the atmosphere ${ }^{5}$. We found that drought strongly stimulated soil $\mathrm{CO}_{2}$ efflux ( $\left.P=0.017\right)$, but, contrary to our expectations, drought did not affect root breakdown in the top $0-7.5-\mathrm{cm}$ of the soil column $\left(F_{(1,19)}=0.28, P=0.599\right)$ and slowed root breakdown in the $7.5-15-\mathrm{cm}$ depth range $\left(F_{(1,19)}=7.65, P=0.012\right)$. This could potentially be a result of changes in peat chemistry during short-term drought conditions. In Sphagnum peatlands, the build-up of phenolics in the soil during short-term drought can inhibit soil $\mathrm{CO}_{2}$ efflux and preserve stored $\mathrm{C}^{6}$. Another possible factor is that the amount of surface area exposed to oxygen 
was likely different at the soil surface compared to roots buried in the soil. Although water fell below the lowest depth of the roots, residual water within the rooting zone could have kept oxygen levels low ${ }^{31,32}$. Drought-induced stimulation of soil $\mathrm{CO}_{2}$ efflux ( $\left.194 \mathrm{~g} \mathrm{C} \mathrm{m}^{-2} \mathrm{yr}^{-1}\right)$ was much greater than the decline in overall root (no change) and leaf $\operatorname{litter}\left(\sim 12 \mathrm{~g} \mathrm{C} \mathrm{m}^{-2} \mathrm{yr}^{-1}\right)$ decomposition, indicating that decomposition is not a significant factor driving $\mathrm{C}$ loss from the ecosystem (Table 1).

Combined, elevated salinity and drought treatments shifted NEP from a small to large $\mathrm{CO}_{2}$ source compared to the control monoliths $(P<0.001$; Table 1$)$. This result was expected, given the physiological salt stress to vegetation ${ }^{33}$ and strong soil oxidation under drought ${ }^{4}$. Even under ambient salinity and completely inundated conditions, the brackish marsh in our study was also a net source of $\mathrm{C}$ to the atmosphere (Table 1), supporting other studies that found this same conclusion ${ }^{18,19}$. This may help explain why peat collapse is already being observed in brackish wetlands of the Everglades (Fig. 1). As marshes transition from freshwater to brackish, a decline in GEP leads to a subsequent decline in organic matter inputs and shifts the marsh from a net $\mathrm{CO}_{2}$ sink to source ${ }^{19}$.

\section{IMPLICATIONS FOR PEAT COLLAPSE}

Although many coastal wetlands around the world are experiencing ecosystem alterations as the result of changing climate conditions and accelerated $\mathrm{SLR}^{34}$, the rate of ecosystem change and peat collapse observed in the coastal Everglades is unprecedented $^{23}$. While we found that both root and litter decomposition slowed with elevated salinity, the overall impact of decomposition on the NECB was minimal compared to the reduction in GEP and organic matter inputs (Table 1). Although soil 
bulk density in our study was unaffected by elevated salinity, soil organic matter, C, and $\mathrm{N}$ content all declined (Table S4). Under inundated conditions, we measured a substantial amount of soil elevation loss $(\sim 3.0 \mathrm{~cm})$ with elevated salinity over only a one-year period (Fig. 2). We attribute this elevation loss to the sharp reduction in organic matter inputs with elevated salinity and a net release of $\mathrm{CO}_{2}$ to the atmosphere. To put this in perspective, coastal marshes accrete slowly over time, usually at or near the same pace as SLR $\left(\sim 2 \text { to } 10 \mathrm{~mm} \mathrm{yr}^{-1}\right)^{34-38}$. The peat marshes within the interior Everglades, those which do not receive sedimentation from tidal flushing, have been accreting even slower $\left(\sim 0.5 \text { to } 2 \mathrm{~mm} \mathrm{yr}^{-1}\right)^{39,40}$.

Surprisingly, even under ambient salinity and inundated conditions, we saw a $\sim 2.9 \mathrm{~cm}$ soil elevation loss over the same period, indicating that the mechanisms that drive peat collapse in the coastal Everglades begin before the marsh fully transitions to brackish conditions $(\sim 10 \mathrm{ppt})$. Soil elevation loss under brackish conditions $(\sim 10 \mathrm{ppt})$ is further supported in a related mesocosm experiment with freshwater sawgrass-peat monoliths that measured $\mathrm{a} \sim 2.8 \mathrm{~cm}$ decrease in soil elevation after one year of exposure to elevated salinity of $\sim 9$ ppt (Fig. 3$)^{24}$. In the same study, Wilson et al. (in prep) saw that, although NEP was unaffected by elevated salinity, there was a decrease in the quantity of live roots in the soil, the same result found in this study. Therefore, a decrease in root production and/or an increase in root mortality is one of the primary mechanisms causing peat collapse. 


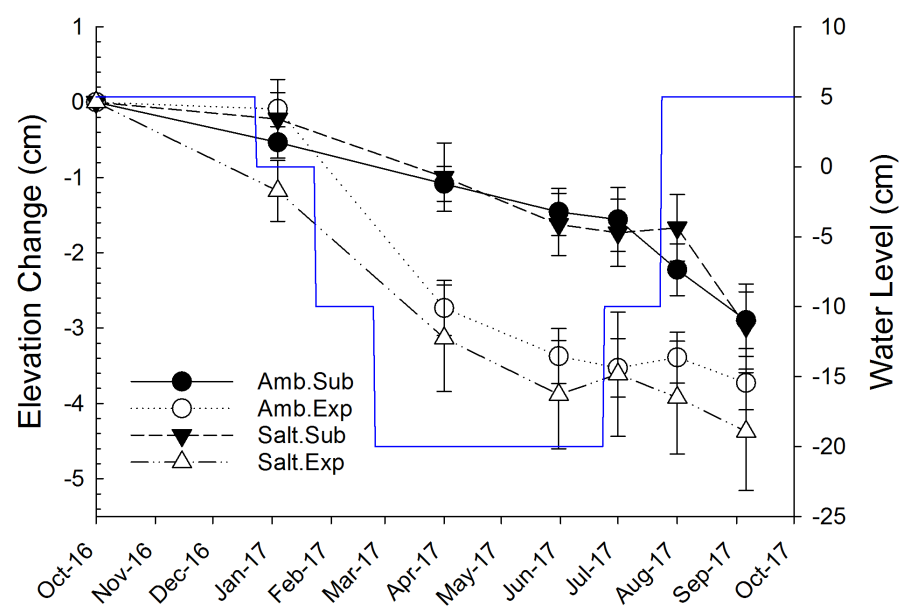

Figure 2. Soil elevation change relative to the elevation at the start of the experiment. Also plotted is water depth relative to the soil surface (blue line). Points represent mean $(n=6) \pm 1$ SE. Amb = Ambient salinity, Salt = Elevated Salinity, Sub = Submerged, Exp $=$ Exposed.

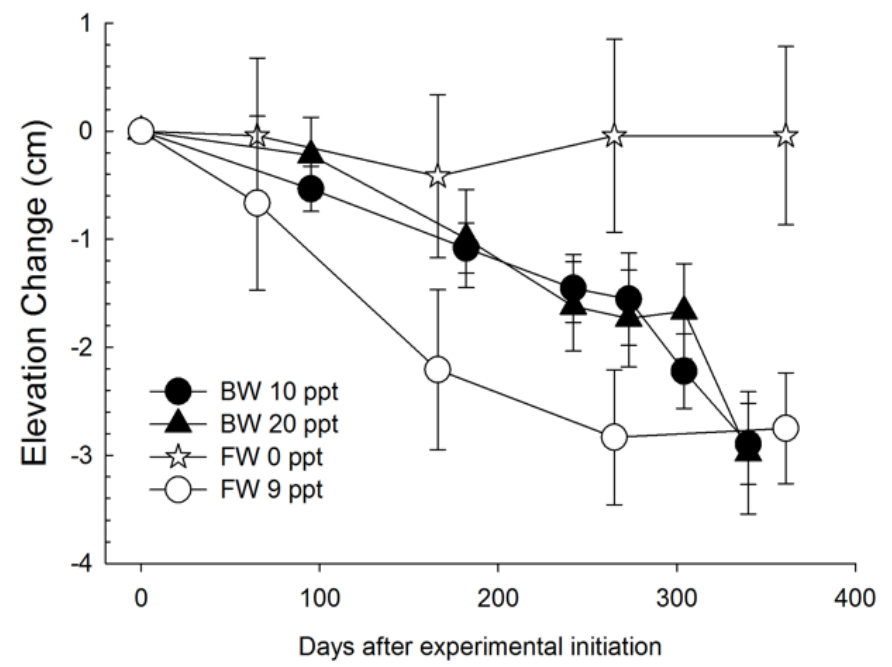

Figure 3. Soil elevation change relative to the elevation at the start of two separate experiments. The data plotted come from this experiment (filled symbols) and from a similar mesocosm experiment on freshwater sawgrass peat monoliths (open symbols) ${ }^{24}$. All treatments were not subjected to drought and were completely inundated for the entire experimental period. Points represent mean $(n=6) \pm 1 \mathrm{SE} . \mathrm{BW}=$ brackish water, $\mathrm{FW}=$ freshwater, $\mathrm{ppt}=$ parts per thousand salinity. 
Peat collapse in the coastal Everglades is not only a function of elevated salinity, but appears to be accelerated by seasonal dry-down. Surface water dry-down during the drought period in our experiment accelerated peat collapse; we measured 3 to $4 \mathrm{~cm}$ of peat collapse from this brackish water marsh over the course of only one year, with most of the collapse occurring during the onset of dry-down (Fig. 1). It is important to note that, although we only continued to measure elevation change for two months after water was brought back above the soil surface in the drought treatments, the elevation lost during drought did not return. When we conducted this experiment, we mimicked our drought water level regime based on field data from 2015 when the region was experiencing "exceptional" drought. We thought water falling 20 -cm below the soil surface was not common and represented an anomalous year. However, when we looked at long-term water level data near the brackish water site where we collected our monoliths (EDEN gauge NP6, USGS), dating back to 2001, dry-down occurred every year, to an average depth of $29.7 \mathrm{~cm}$, and an average duration of 3.9 months (Fig. 4). Therefore, although we expected drought to strongly impact the NECB and elevation, we did not expect that our "drought" treatment was a near-annual occurrence for this marsh.

Further alarming is how seasonal dry-down caused porewater salinity within the soil to increase in a step-wise function at the brackish water site. Three years of monthly ambient porewater salinity from the site shows strong change-points (Fig. 5). Every instance in which water fell below the soil surface coincided with a spike in salinity. This is likely caused by strong groundwater upwelling of brackish water when surface water disappears ${ }^{19,41,42}$. Additionally, porewater salinity at the marsh stayed elevated during wet periods despite much lower salinity in the surface water, and when the next dry-down 
event occurred, porewater salinity spiked (Fig. 5). Because these dry-down events occur annually in these brackish marshes of the Everglades, it is likely that porewater salinity in these marshes will continue to rise, leading to further reductions in the NECB and organic matter inputs, further driving peat collapse.
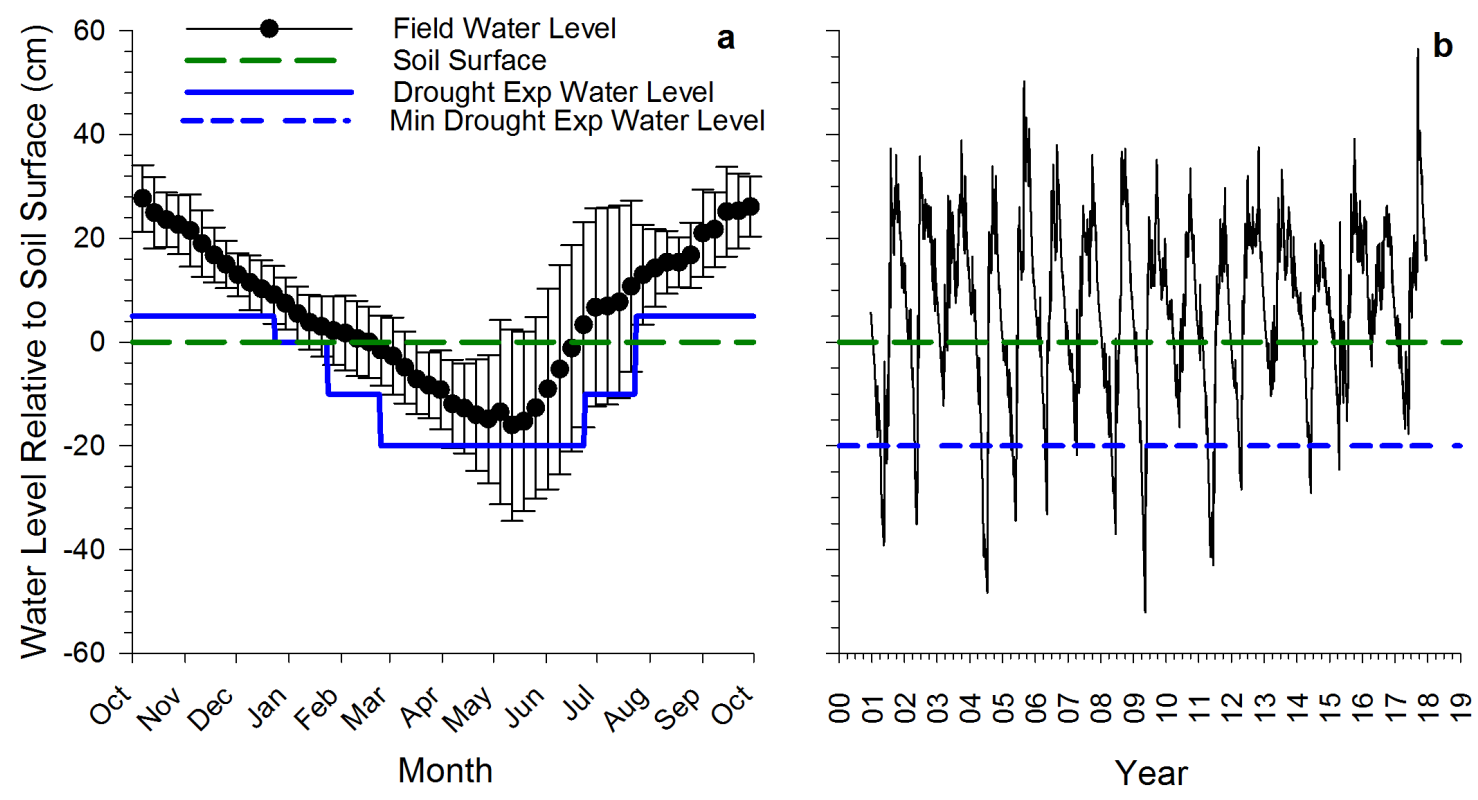

Figure 4. Historical water level from a brackish water site in the Everglades. (a) Weekly mean $(n=7) \pm 1 \mathrm{SD}$ water level at the brackish water site relative to the soil surface from 2001 to 2017. (b) Daily water level at the brackish water site from 2001 to 2017. The dashed line represents the soil surface, while the blue line represents either the water level during our one year mesocosm experiment (a) or the minimum water level in our drought experiment $(-20 \mathrm{~cm} ; \mathrm{b})$. Water level data comes from the USGS EDEN gauge NP6. 


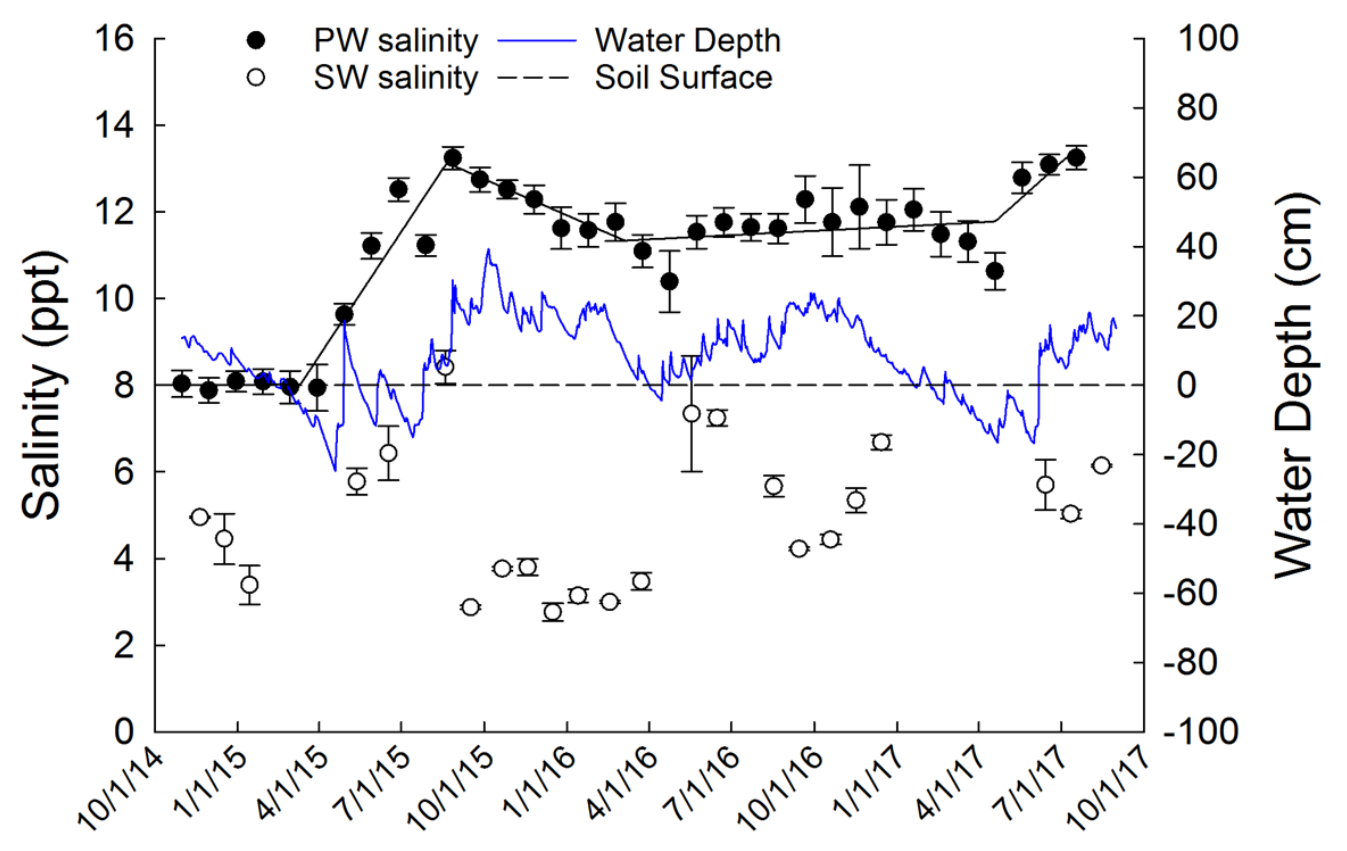

Figure 5. Ambient porewater and surface water salinity at the brackish water marsh. Mean $(n=6) \pm 1$ SE of monthly porewater (PW) and surface water (SW) salinity (ppt) and daily water depth relative to the soil surface from the brackish water site within the + ambient-water plots ${ }^{19}$. Soil surface is plotted as the $0-\mathrm{cm}$ water mark (dashed line) to show its relation to water depth. Solid black lines show the results of a piecewise regression with relevant change-points for PW salinity.

Historical water management practices in the Everglades have significantly altered the water balance and hydroperiod of southern, coastal wetlands by diverting upstream freshwater flows into Biscayne Bay and the Gulf of Mexico, thereby starving southern marshes of freshwater ${ }^{11,43,44}$. Because seasonal dry-down can accelerate peat collapse (Fig. 2), the restoration of flow regimes to the coastal Everglades has the potential to mitigate peat collapse. Increased water flows can mitigate peat collapse in two ways. First, enahnced freshwater delivery to coastal areas recharges aquifers and creates a stronger freshwater head that helps hold back saltwater intrusion ${ }^{42,45}$. Second, longer periods of inundation, even with brackish water, can prevent strong, seasonal dry- 
down events from occurring ${ }^{46}$. This would greatly reduce groundwater intrusion of marine water into the coastal marshes (Fig. 5) and prevent the acceleration of peat collapse. While it is unlikely that these marshes will ever recover to pre-collapsed conditions in the near future, enhanced water delivery has the potential to slow down collapse and allow for the recruitment and establishment of mangroves that help stabilize the soil ${ }^{47}$. However, given accelerating SLR and delays in the implementation of Comprehensive Everglades Restoration Plan projects ${ }^{48}$, further collapse of peat marshes within the coastal Everglades can be expected. Understanding the drivers and mechanisms behind this collapse is urgently needed to inform management practices aimed at preventing peat collapse and the transformation of marsh habitat to open water ponds in the Everglades and other coastal peatlands ${ }^{7,21,49}$.

\section{ACKNOWLEDGEMENTS}

Funding for research was supported by a National Science Foundation Doctoral Dissertation Improvement Grant (DEB- 1701763). Additional funding came from Florida Sea Grant R/C-S-56, including cooperative agreements with the South Florida Water Management District, the Everglades Foundation, and Everglades National Park, and the National Science Foundation's Florida Coastal Everglades Long Term Ecological Research Program (DEB-1237517). We thank Lauran Bauman and Ryan Stolee for help in the field. Benjamin Wilson was supported by a Florida International University Teaching Assistantship, Florida Sea Grant, FCE LTER, and FIU Dissertation Year Fellowship. This is contribution xxxx of the Southeast Environmental Research Center. 


\section{LITERATURE CITED}

1 Limpens, J. et al. Peatlands and the carbon cycle: from local processes to global implications - a synthesis. Biogeosciences 5, 1475-1491 (2008).

2 Newman, S. et al. Drivers of landscape evolution: multiple regimes and their influence on carbon sequestration in a sub-tropical peatland. Ecological Monographs 87, 578-599, doi:10.1002/ecm.1269 (2017).

3 Malone, S. L., Starr, G., Staudhammer, C. L. \& Ryan, M. G. Effects of simulated drought on the carbon balance of Everglades short-hydroperiod marsh. Global Change Biology 19, 2511-2523, doi:10.1111/gcb.12211 (2013).

4 Ise, T., Dunn, A. L., Wofsy, S. C. \& Moorcroft, P. R. High sensitivity of peat decomposition to climate change through water-table feedback. Nature Geoscience 1, 763-766, doi:10.1038/ngeo331 (2008).

5 Fenner, N. \& Freeman, C. Drought-induced carbon loss in peatlands. Nature Geoscience 4, 895-900, doi:10.1038/ngeo1323 (2011).

6 Wang, H. J., Richardson, C. J. \& Ho, M. C. Dual controls on carbon loss during drought in peatlands. Nature Climate Change 5, 584-U145 (2015).

7 Cahoon, D. R. et al. Mass tree mortality leads to mangrove peat collapse at Bay Islands, Honduras after Hurricane Mitch. Journal of Ecology 91, 1093-1105, doi:10.1046/j.1365-2745.2003.00841.x (2003).

8 Laiho, R. Decomposition in peatlands: Reconciling seemingly contrasting results on the impacts of lowered water levels. Soil Biology \& Biochemistry 38, 20112024, doi:10.1016/j.soilbio.2006.02.017 (2006).

9 Henman, J. \& Poulter, B. Inundation of freshwater peatlands by sea level rise: Uncertainty and potential carbon cycle feedbacks. Journal of Geophysical Research-Biogeosciences 113, doi:10.1029/2006jg000395 (2008).

10 Joosten, H. The Global Peatland CO2 Picture. Peatland Status and Drainage Related Emissions in All Countries of The World. (Ede, 2009).

11 McVoy, C. W., Said, W. P., Obeysekera, J., Van Arman, J. \& Dreschel, T. W. Landscapes and Hydrology of the Predrainage Everglades. 576 (University of Florida Press, 2011).

12 Poffenbarger, H. J., Needelman, B. A. \& Megonigal, J. P. Salinity influence on methane emissions from tidal marshes. Wetlands 31, 831-842, doi:10.1007/s13157-011-0197-0 (2011). 
13 Weston, N. B., Vile, M. A., Neubauer, S. C. \& Velinsky, D. J. Accelerated microbial organic matter mineralization following salt-water intrusion into tidal freshwater marsh soils. Biogeochemistry 102, 135-151, doi:10.1007/s10533-0109427-4 (2011).

14 Marton, J. M., Herbert, E. R. \& Craft, C. B. Effects of Salinity on Denitrification and Greenhouse Gas Production from Laboratory-incubated Tidal Forest Soils. Wetlands 32, 347-357, doi:10.1007/s13157-012-0270-3 (2012).

15 Neubauer, S. C. Ecosystem responses of a tidal freshwater marsh experiencing saltwater intrusion and altered hydrology. Estuaries and Coasts 36, 491-507, doi:10.1007/s12237-011-9455-x (2013).

16 Weston, N. B., Neubauer, S. C., Velinsky, D. J. \& Vile, M. A. Net ecosystem carbon exchange and the greenhouse gas balance of tidal marshes along an estuarine salinity gradient. Biogeochemistry 120, 163-189 (2014).

17 Herbert, E. R. et al. A global perspective on wetland salinization: ecological consequences of a growing threat to freshwater wetlands. Ecosphere 6, doi:10.1890/es14-00534.1 (2015).

18 Wilson, B. J. et al. Declines in plant productivity drive carbon loss from coastal wetland mesocosms exposed to saltwater intrusion. Global Change Biology (In Review).

19 Wilson, B. J. et al. Salinity pulses in brackish and freshwater marshes interact with seasonal dry-down to increase ecosystem carbon loss in the Florida Coastal Everglades. Ecological Applications (In Prep).

20 Wilson, B. J. et al. Balancing nutrient subsidy and salinity stress: short- and longterm effects of saltwater intrusion on freshwater wetland ecosystem functions. Ecology (In Prep).

21 Delaune, R. D., Nyman, J. A. \& Patrick, W. H. Peat collapse, ponding and wetland loss in a rapidly submerging coastal marsh. Journal of Coastal Research 10, 1021-1030 (1994).

22 Whittle, A. \& Gallego-Sala, A. V. Vulnerability of the peatland carbon sink to sea-level rise. Scientific Reports 6, doi:10.1038/srep28758 (2016).

23 Wanless, H. R. \& Vlaswinkel, B. M. Coastal landscape and channel evolution affecting critical habitats at Cape Sable, Everglades National Park, Florida. 197 (2005). 
24 Charles, S. P. Quantifying the effects of saltwater intrusion and sea-level rise on carbon storage and elevation change in Everglades coastal marshes. (In prep).

25 Nyman, J. A., Walters, R. J., Delaune, R. D. \& Patrick, W. H., Jr. Marsh vertical accretion via vegetative growth. Estuarine Coastal and Shelf Science 69, 370-380, doi:10.1016/j.ecss.2006.05.041 (2006).

26 McKee, K. L. Biophysical controls on accretion and elevation change in Caribbean mangrove ecosystems. Estuarine Coastal and Shelf Science 91, 475483, doi:10.1016/j.ecss.2010.05.001 (2011).

27 Baustian, J. J., Mendelssohn, I. A. \& Hester, M. W. Vegetation's importance in regulating surface elevation in a coastal salt marsh facing elevated rates of sea level rise. Global Change Biology 18, 3377-3382, doi:10.1111/j.13652486.2012.02792.x (2012).

28 Pezeshki, S. R., Delaune, R. D. \& Patrick, W. H. Assessment of saltwater intrusion impact on gas exchange behavior of Louisiana Gulf Coast wetland species. Wetland Ecology and Management 1, 21-30 (1989).

29 Chambers, L. G., Reddy, K. R. \& Osborne, T. Z. Short-Term Response of Carbon Cycling to Salinity Pulses in a Freshwater Wetland. Soil Science Society of America Journal 75, 2000-2007, doi:10.2136/sssaj2011.0026 (2011).

30 Wang, C., Tong, C., Chambers, L. G. \& Liu, X. Identifying the Salinity Thresholds that Impact Greenhouse Gas Production in Subtropical Tidal Freshwater Marsh Soils. Wetlands 37, 559-571, doi:doi:10.1007/s13157-0170890-8 (2017).

31 Nyman, J. A. \& Delaune, R. D. $\mathrm{CO}_{2}$ emission and soil Eh responses to different hydrological conditions in fresh, brackish, and saline marsh soils. Limnology and Oceanography 36, 1406-1414 (1991).

32 Agosta, K. The effect of tidally induced changes in the creekbank water-table on pore water chemistry. Estuarine Coastal and Shelf Science 21, 389-400, doi:10.1016/0272-7714(85)90019-8 (1985).

33 Munns, R. \& Tester, M. Mechanisms of salinity tolerance. Annual Review of Plant Biology 59, 651-681, doi:10.1146/annurev.arplant.59.032607.092911 (2008).

34 Kirwan, M. L. \& Megonigal, J. P. Tidal wetland stability in the face of human impacts and sea-level rise. Nature 504, 53-60, doi:10.1038/nature12856 (2013). 
35 Morris, J. T., Sundareshwar, P. V., Nietch, C. T., Kjerfve, B. \& Cahoon, D. R. Responses of coastal wetlands to rising sea level. Ecology 83, 2869-2877, doi:10.2307/3072022 (2002).

36 Kirwan, M. L. \& Mudd, S. M. Response of salt-marsh carbon accumulation to climate change. Nature 489, 550-+, doi:10.1038/nature11440 (2012).

37 Kirwan, M. L., Temmerman, S., Skeehan, E. E., Guntenspergen, G. R. \& Fagherazzi, S. Overestimation of marsh vulnerability to sea level rise. Nature Climate Change 6, 253-260, doi:10.1038/nclimate2909 (2016).

38 French, J. Tidal marsh sedimentation and resilience to environmental change: Exploratory modelling of tidal, sea-level and sediment supply forcing in predominantly allochthonous systems. Marine Geology 235, 119-136, doi:10.1016/j.margeo.2006.10.009 (2006).

39 Craft, C. B. \& Richardson, C. J. Peat accretion and N, P, and organic C accumulation in nutrient-enriched and unenriched Everglades peatlands. Ecological Applications 3, 446-458, doi:10.2307/1941914 (1993).

40 Craft, C. B. \& Richardson, C. J. in Everglades Experiments. Soil Characteristics in the Everglades Peatland. p. 59-72 (Springer, 2008).

41 Price, R. M., Swart, P. K. \& Fourqurean, J. W. Coastal groundwater discharge an additional source of phosphorus for the oligotrophic wetlands of the Everglades. Hydrobiologia 569, 23-36, doi:10.1007/s10750-006-0120-5 (2006).

42 Dessu, S. B., Price, R. M., Troxler, T. G. \& Kominoski, J. S. Effects of sea-level rise and freshwater management on long-term water levels and water quality in the Florida Coastal Everglades. Journal of Environmental Management In Press (2018).

43 Light, S. S. \& Dineen, J. W. in Everglades: The Ecosystem and its Restoration. Water control in the Everglades: A historical perspective. (eds S. M. Davis \& J. C. Ogden) p. 47-84 (St. Lucie Press, 1994).

44 Sklar, F. et al. in Everglades Consolidated Report. Hydrological needs-effects of hydrology on the Everglades. (South Florida Water Management District, 2000).

45 Koch, M. S. et al. Climate Change Projected Effects on Coastal Foundation Communities of the Greater Everglades Using a 2060 Scenario: Need for a New Management Paradigm. Environmental Management 55, 857-875, doi:10.1007/s00267-014-0375-y (2015). 
46 Sklar, F. H., Fitz, H. C., Wu, Y., Van Zee, R. \& McVoy, C. The design of ecological landscape models for Everglades restoration. Ecological Economics 37, 379-401, doi:10.1016/s0921-8009(01)00180-х (2001).

47 Jiang, J., DeAngelis, D. L., Anderson, G. H. \& Smith, T. J. Analysis and Simulation of Propagule Dispersal and Salinity Intrusion from Storm Surge on the Movement of a Marsh-Mangrove Ecotone in South Florida. Estuaries and Coasts 37, 24-35, doi:10.1007/s12237-013-9666-4 (2014).

48 National Academies of Sciences, E., and Medicine. Progress Toward Restoring the Everglades: The Sixth Biennial Review - 2016. (The National Academies Press, 2016).

49 Deegan, L. A. et al. Coastal eutrophication as a driver of salt marsh loss. Nature 490, 388-+, doi:10.1038/nature11533 (2012). 


\section{SUPPLEMENTAL INFORMATION}

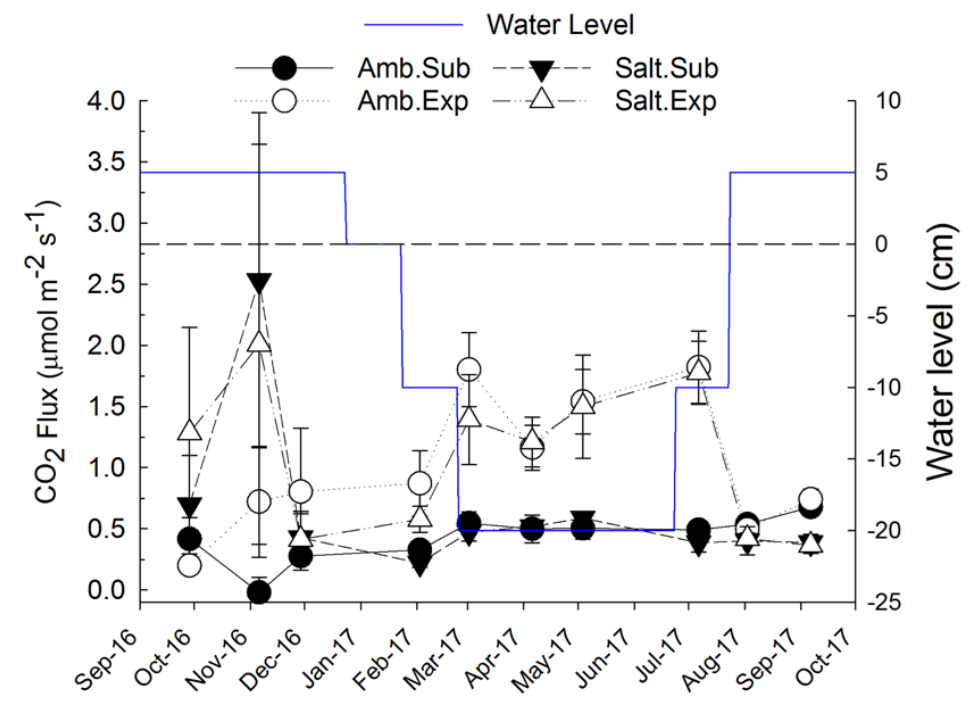

Figure S1. Soil $\mathrm{CO}_{2}$ efflux and water level relative to the soil surface plotted over time. Points represent mean $(n=6) \pm 1 \mathrm{SE}$. Amb = Ambient salinity, Salt = Elevated Salinity, $\mathrm{Sub}=$ Submerged, Exp $=$ Exposed. Also plotted is water depth (blue line) relative to the soil surface (black line). 

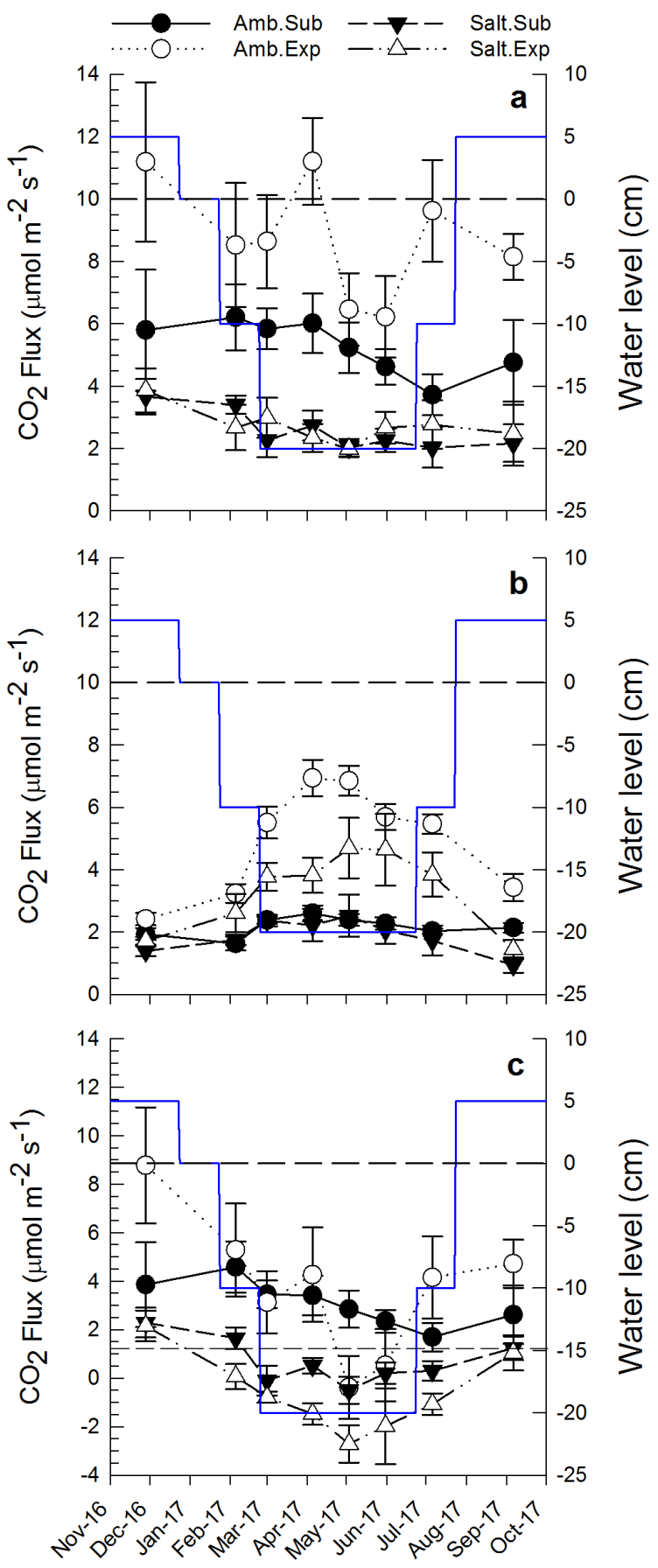

Figure S2. Monthly instantaneous gross ecosystem productivity (GEP) (a), ecosystem respiration of $\mathrm{CO}_{2}\left(\mathrm{ER}_{\mathrm{CO} 2}\right)(\mathrm{b})$, and net ecosystem productivity (NEP) (c) in micromoles of $\mathrm{CO}_{2}$ per meter squared per second over the experimental period. A negative value indicates a flux of $\mathrm{CO}_{2}$ from the marsh to the atmosphere. Also plotted is water depth (blue line) relative to the soil surface (black line). Points represent mean $(n=4) \pm 1 \mathrm{SE}$. $\mathrm{Amb}=$ Ambient salinity, Salt $=$ Elevated Salinity, $\mathrm{Sub}=$ Submerged, Exp $=$ Exposed. 

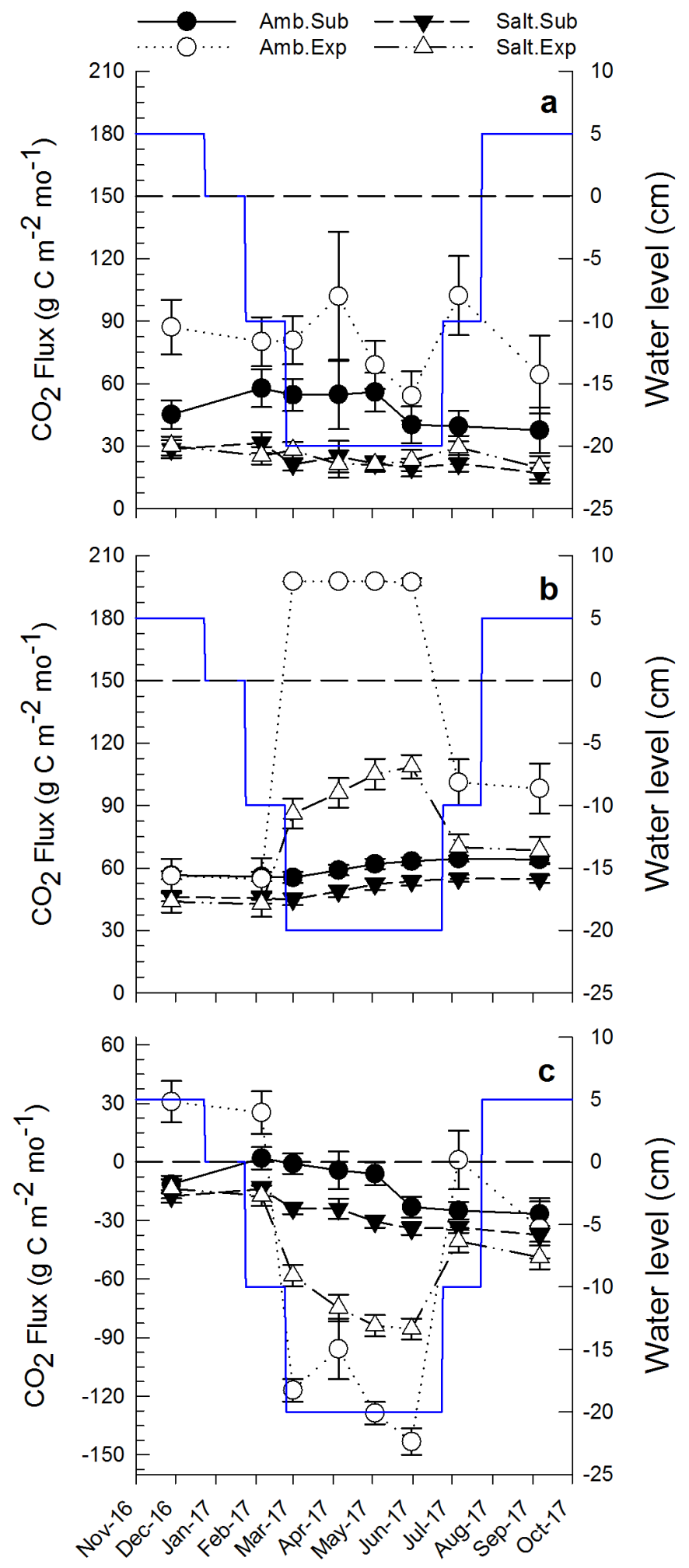
Figure S3. Monthly modeled gross ecosystem productivity (GEP) (a), ecosystem respiration of $\mathrm{CO}_{2}\left(\mathrm{ER}_{\mathrm{CO} 2}\right)(\mathrm{b})$, and net ecosystem productivity (NEP) (c) in g of C per meter squared per month over the experimental period. Fluxes were modeled from instantaneous flux based on empirical relationships between GEP and light and $\mathrm{ER}_{\mathrm{CO} 2}$ and temperature (See Supplemental Methods). A negative value indicates a flux of $\mathrm{CO}_{2}$ from the marsh to the atmosphere. Also plotted is water depth (blue line) relative to the soil surface (black line). Points represent mean $(n=4) \pm 1$ SD. Amb $=$ Ambient salinity, Salt $=$ Elevated Salinity, Sub $=$ Submerged, Exp $=$ Exposed. 
Table S1. Timeline of water level for the control and drought treatment meant to mimic the water level during the 2015 drought at the brackish water marsh where the soil monoliths were collected. Salinity in the ambient salinity monoliths remained at $\sim 10 \mathrm{ppt}$ for the duration of the experiment, while the elevated salinity monoliths were raised to $\sim 15$ ppt in Oct 2016 and $\sim 20$ ppt in Nov 2016 and remained at this level for the duration of the experiment.

\begin{tabular}{rrr}
\hline Date & $\begin{array}{r}\text { Control water } \\
\text { level }\end{array}$ & $\begin{array}{r}\text { Drought water } \\
\text { level }\end{array}$ \\
\hline Sep 2016 & Submerged & $\begin{array}{r}\text { Submerged } \\
\text { Submerged }\end{array}$ \\
Oct 2016 & Submerged & Submerged \\
Nov 2016 & Submerged & Submerged \\
\hline Dec 2016 & Submerged & At Soil Surface \\
Jan 2017 & Submerged & $-10 \mathrm{~cm}$ \\
\hline Feb 2017 & Submerged & $-20 \mathrm{~cm}$ \\
\hline Mar 2017 & Submerged & $-20 \mathrm{~cm}$ \\
\hline Apr 2017 & Submerged & $-20 \mathrm{~cm}$ \\
\hline May 2017 & Submerged & $-20 \mathrm{~cm}$ \\
\hline Jun 2017 & Submerged & $-10 \mathrm{~cm}$ \\
\hline Jul 2017 & Submerged & Submerged \\
\hline Aug 2017 & Submerged & Submerged \\
\hline Sep 2017 & Submerged &
\end{tabular}


Table S2. Full statistical results for the linear mixed model run with time as an independent variable for C flux, change in biomass, and change in elevation. Interpreted results are in bold. Data presented as $F$ (numerator degrees of freedom,denominator degrees of freedom) $=F$ value, $P=P$ value.

$G E P$ gross ecosystem productivity, $E R_{C O 2}$ ecosystem respiration of $\mathrm{CO}_{2}, N E P$ net ecosystem productivity, $A N P P$ aboveground net primary productivity.

\begin{tabular}{|c|c|c|c|c|c|c|c|}
\hline & Salinity & Inundation & Time & $\begin{array}{l}\text { Salinity* } \\
\text { Inundation }\end{array}$ & Salinity*Time & $\begin{array}{l}\text { Inundation* } \\
\text { Time }\end{array}$ & $\begin{array}{l}\text { Salinity* } \\
\text { Inundation* } \\
\text { Time }\end{array}$ \\
\hline Soil $\mathrm{CO}_{2}$ & $\begin{array}{l}F(1,4)=0.52 \\
P=0.509\end{array}$ & $\begin{array}{l}F(1,4)=15.07 \\
P=0.017\end{array}$ & $\begin{array}{l}F(9,186)=2.21 \\
P=0.022\end{array}$ & $\begin{array}{l}F(1,4)=0.37 \\
P=0.574\end{array}$ & $\begin{array}{l}F(9,186)=2.65 \\
P=0.006\end{array}$ & $\begin{array}{l}F(9,186)=1.35 \\
P=0.210\end{array}$ & $\begin{array}{l}F(9,186)=0.39 \\
P=0.935\end{array}$ \\
\hline GEP & $\begin{array}{l}F(1,4)=6.40 \\
P=0.064\end{array}$ & $\begin{array}{l}F(1,4)=9.11 \\
P=0.056\end{array}$ & $\begin{array}{l}F(7,84)=5.06 \\
P<0.001\end{array}$ & $\begin{array}{l}F(1,4)=10.14 \\
P=0.049\end{array}$ & $\begin{array}{l}F(7,84)=1.60 \\
P=0.145\end{array}$ & $\begin{array}{l}F(7,84)=1.80 \\
P=0.097\end{array}$ & $\begin{array}{l}F(7,84)=1.63 \\
P=0.137\end{array}$ \\
\hline $\mathbf{E R}_{\mathrm{CO} 2}$ & $\begin{array}{l}F(1,4)=5.91 \\
P=0.071\end{array}$ & $\begin{array}{l}F(1,4)=14.58 \\
P=0.031\end{array}$ & $\begin{array}{l}F(7,84)=28.21 \\
P<0.001\end{array}$ & $\begin{array}{l}F(1,4)=2.49 \\
P=0.212\end{array}$ & $\begin{array}{l}F(7,84)=2.16 \\
P=0.045\end{array}$ & $\begin{array}{l}F(7,84)=10.21 \\
P<0.001\end{array}$ & $\begin{array}{l}F(7,84)=1.82 \\
P=0.093\end{array}$ \\
\hline NEP & $\begin{array}{l}F(1,4)=3.63 \\
P=0.129\end{array}$ & $\begin{array}{l}F(1,4)=0.07 \\
P=0.801\end{array}$ & $\begin{array}{l}F(7,84)=15.54 \\
P<0.001\end{array}$ & $\begin{array}{l}F(1,4)=2.13 \\
P=0.175\end{array}$ & $\begin{array}{l}F(7,84)=1.31 \\
P=0.251\end{array}$ & $\begin{array}{l}F(7,84)=4.18 \\
P<0.001\end{array}$ & $\begin{array}{l}F(7,84)=1.80 \\
P=0.097\end{array}$ \\
\hline Biomass & $\begin{array}{l}F(1,92)=10.60 \\
P=0.001\end{array}$ & $\begin{array}{l}F(1,4)=1.55 \\
P=0.281\end{array}$ & $\begin{array}{l}F(4,92)=16.74 \\
P<0.001\end{array}$ & $\begin{array}{l}F(1,92)=0.00 \\
P=0.970\end{array}$ & $\begin{array}{l}F(4,92)=1.41 \\
P=0.234\end{array}$ & $\begin{array}{l}F(4,92)=0.33 \\
P=0.855\end{array}$ & $\begin{array}{l}F(4,92)=0.04 \\
P=0.996\end{array}$ \\
\hline $\begin{array}{l}\text { Culm } \\
\text { Density }\end{array}$ & $\begin{array}{l}F(1,92)=0.06 \\
P=0.793\end{array}$ & $\begin{array}{l}F(1,4)=1.89 \\
P=0.240\end{array}$ & $\begin{array}{l}F(4,92)=1.46 \\
P=0.218\end{array}$ & $\begin{array}{l}F(1,92)=27.87 \\
P<0.001\end{array}$ & $\begin{array}{l}F(4,92)=1.91 \\
P=0.114\end{array}$ & $\begin{array}{l}F(4,92)=0.66 \\
P=0.621\end{array}$ & $\begin{array}{l}F(4,92)=0.38 \\
P=0.823\end{array}$ \\
\hline ANPP & $\begin{array}{l}F(1,71)=0.53 \\
P=0.465\end{array}$ & $\begin{array}{l}F(1,4)=0.14 \\
P=0.723\end{array}$ & $\begin{array}{l}F(3,71)=3.76 \\
P=0.014\end{array}$ & $\begin{array}{l}F(1,71)=0.19 \\
P=0.657\end{array}$ & $\begin{array}{l}F(3,71)=4.56 \\
P=0.005\end{array}$ & $\begin{array}{l}F(3,71)=0.92 \\
P=0.432\end{array}$ & $\begin{array}{l}F(3,71)=0.86 \\
P=0.463\end{array}$ \\
\hline Elevation & $\begin{array}{l}F(1,4)=0.10 \\
P=0.758\end{array}$ & $\begin{array}{l}F(1,4)=4.90 \\
P=0.091\end{array}$ & $\begin{array}{l}F(5,400)=22.22 \\
P<0.001\end{array}$ & $\begin{array}{l}F(1,4)=0.21 \\
P=0.665\end{array}$ & $\begin{array}{l}F(5,400)=0.13 \\
P=0.983\end{array}$ & $\begin{array}{l}F(5,400)=2.61 \\
P=0.024\end{array}$ & $\begin{array}{l}F(5,400)=0.38 \\
P=0.858\end{array}$ \\
\hline $\begin{array}{l}\text { Modeled } \\
\text { GEP }\end{array}$ & $\begin{array}{l}F(1,83)=36.95 \\
P<0.001\end{array}$ & $\begin{array}{l}F(1,4)=2.34 \\
P=0.200\end{array}$ & $\begin{array}{l}F(7,83)=4.43 \\
P<0.001\end{array}$ & $\begin{array}{l}F(1,83)=0.00 \\
P=0.940\end{array}$ & $\begin{array}{l}F(7,83)=1.90 \\
P=0.078\end{array}$ & $\begin{array}{l}F(7,83)=2.29 \\
P=0.034\end{array}$ & $\begin{array}{l}F(7,83)=1.90 \\
P=0.078\end{array}$ \\
\hline $\begin{array}{l}\text { Modeled } \\
\text { NEP }\end{array}$ & $\begin{array}{l}F(1,83)=0.00 \\
P=0.948\end{array}$ & $\begin{array}{l}F(1,4)=0.89 \\
P=0.398\end{array}$ & $\begin{array}{l}F(7,83)=21.78 \\
P<0.001\end{array}$ & $\begin{array}{l}F(1,83)=17.97 \\
P<0.001\end{array}$ & $\begin{array}{l}F(7,83)=2.14 \\
P=0.047\end{array}$ & $\begin{array}{l}F(7,83)=5.32 \\
P<0.001\end{array}$ & $\begin{array}{l}F(7,83)=2.18 \\
P=0.043\end{array}$ \\
\hline
\end{tabular}


Table S3. Instantaneous $\mathrm{CO}_{2}$ flux rates taken near solar noon. Values represent the mean $\left(\mu \mathrm{mol} \mathrm{CO}_{2} \mathrm{~m}^{-2} \mathrm{~s}^{-1}\right) \pm 1 \mathrm{SE}_{\text {for soil CO}}$, gross ecosystem productivity (GEP), ecosystem respiration of $\mathrm{CO}_{2}\left(\mathrm{ER}_{\mathrm{CO} 2}\right)$, and net ecosystem productivity (NEP). A negative NEP indicates overall $\mathrm{CO}_{2}$ release from the marsh to the atmosphere. Flux rates for each parameter is plotted for three time periods: Overall (Sep 2016 - Sep 2017), Inundated (Sep 2016 - Jan 2017, Aug - Sep 2017), and Drought (Feb - Jul 2017). See mixed model results (Table S2) for significant differences.

$\mathrm{Amb}=$ Ambient salinity, Salt $=$ Elevated Salinity, $\mathrm{Sub}=$ Submerged, Exp $=$ Exposed.

\begin{tabular}{llllll}
\hline & & Amb.Sub & Amb.Exp & Salt.Sub & Salt.Exp \\
\hline Soil CO2 & Overall & $0.42 \pm 0.06$ & $1.02 \pm 0.17$ & $0.66 \pm 0.21$ & $1.09 \pm 0.19$ \\
\hline & Inundated & $0.38 \pm 0.12$ & $0.59 \pm 0.11$ & $0.89 \pm 0.14$ & $0.89 \pm 0.33$ \\
\hline GEP & Drought & $0.47 \pm 0.04$ & $1.44 \pm 0.18$ & $0.44 \pm 0.06$ & $1.29 \pm 0.20$ \\
\hline & Overall & $5.27 \pm 0.30$ & $8.75 \pm 0.67$ & $2.57 \pm 0.22$ & $2.72 \pm 0.19$ \\
\hline \multirow{2}{*}{ ERCO2 } & Inundated & $5.28 \pm 0.52$ & $9.67 \pm 1.52$ & $2.92 \pm 0.75$ & $3.17 \pm 0.69$ \\
\hline & Drought & $5.27 \pm 0.39$ & $8.45 \pm 0.77$ & $2.45 \pm 0.21$ & $2.57 \pm 0.14$ \\
\hline \multirow{2}{*}{ Overall } & $2.18 \pm 0.11$ & $4.94 \pm 0.60$ & $1.87 \pm 0.19$ & $3.32 \pm 0.44$ \\
\hline & Inundated & $2.04 \pm 0.10$ & $2.93 \pm 0.51$ & $1.16 \pm 0.22$ & $1.58 \pm 0.14$ \\
\hline & Drought & $2.22 \pm 0.14$ & $5.62 \pm 0.54$ & $2.11 \pm 0.13$ & $3.90 \pm 0.31$ \\
\hline & Overall & $3.10 \pm 0.32$ & $3.81 \pm 1.01$ & $0.70 \pm 0.33$ & $-0.60 \pm 0.57$ \\
\hline & Inundated & $3.23 \pm 0.62$ & $6.74 \pm 2.03$ & $1.76 \pm 0.52$ & $1.59 \pm 0.55$ \\
\hline & Drought & $3.05 \pm 0.41$ & $2.83 \pm 0.92$ & $0.34 \pm 0.30$ & $-1.33 \pm 0.39$ \\
\hline
\end{tabular}


Table S4. Soil physicochemical properties (mean $\pm \mathrm{SE}, n=6$ ) measured after 1 -year. Amb = Ambient salinity, Salt $=$ Elevated Salinity, Sub $=$ Submerged, Exp $=$ Exposed.

\begin{tabular}{lllllll}
\hline Treatment & Bulk density & Water (\%) & $\begin{array}{l}\text { Organic } \\
\text { Matter (\%) }\end{array}$ & Total C (\%) & Total N (\%) & Total P (\%) \\
\hline Amb.Sub & $0.23 \pm 0.03$ & $83.3 \pm 0.9$ & $81.3 \pm 1.6$ & $41.69 \pm 1.54$ & $1.91 \pm 0.13$ & TBD \\
\hline Amb.Exp & $0.23 \pm 0.03$ & $83.4 \pm 0.8$ & $82.0 \pm 0.3$ & $40.89 \pm 0.30$ & $2.01 \pm 0.03$ & TBD \\
\hline Salt.Sub & $0.24 \pm 0.04$ & $82.7 \pm 0.5$ & $76.8 \pm 1.3$ & $37.20 \pm 1.15$ & $1.74 \pm 0.07$ & TBD \\
\hline Salt.Exp & $0.20 \pm 0.03$ & $82.5 \pm 0.7$ & $76.9 \pm 1.0$ & $37.64 \pm 0.84$ & $1.73 \pm 0.09$ & TBD \\
\hline
\end{tabular}




\section{Supplementary Methods}

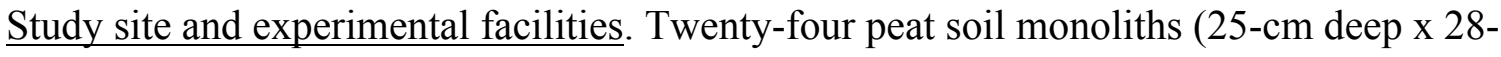
cm diameter) were collected on 3 August 2016 from an oligohaline-mesohaline marsh within Shark River Slough $\left(25^{\circ} 13^{\prime} 13.52^{\prime \prime} \mathrm{N}, 80^{\circ} 50^{\prime} 36.70^{\prime \prime} \mathrm{W}\right)$ of Everglades National Park (ENP), FL, USA. The site was located about $5 \mathrm{~km}$ inland from Florida Bay and was supratidal. The site was dominated by dense sawgrass patches (Cladium jamaicense) interspersed with buttonwood (Conocarpus erectus) and open water ponds with senescing and dead sawgrass plants (Fig. 1). Peat was approximately $1 \mathrm{~m}$ depth to a $\sim 0.5 \mathrm{~m}$ mineral layer overlying limestone bedrock. The soil $\mathrm{C}$ content within the top $10-\mathrm{cm}$ at this site was $42.6 \pm 0.2 \%$ (mean \pm 1 standard error), bulk density was $0.133 \pm 0.008 \mathrm{~g} \mathrm{~cm}^{-3}, 84.5$ $\pm 0.5 \%$ of the soil was organic matter, and water occupied $88.5 \pm 0.8 \%$ of the pore space $^{1}$. At the time of collection, ambient porewater salinity was $\sim 12$ ppt. On site, areas with $\sim 3$ plant culms per $0.06 \mathrm{~m}^{-2}$ were selected for monolith collection We extracted the peat monoliths intact using shovels and placed them into perforated buckets with mesh screen over the perforations that allowed water exchange while minimizing sediment loss

${ }^{2}$. Extracted monoliths were dug out slightly larger than the size of the bucket and were shaved down to a uniform size while being placed into the bucket. Monoliths were transported to an outdoor mesocosm facility at ENP's Florida Bay Interagency Science Center (FBISC) in Key Largo, FL.

We used a randomized split-plot experimental design with repeated measurements. The two manipulated factors were salinity (the whole-plot factor) and inundation (the sub-plot factor), which were both fixed factors. Once on site, monoliths were carefully immersed in six 250-gallon concrete tanks equipped with an adjustable 
inflow spigot, a $30-\mathrm{cm}$ tall standpipe to maintain consistent water level, and an outflow drain; three tanks had elevated salinity (20 ppt), while three had ambient salinity (10 ppt). Within each tank, the water depth for a monolith was controlled by setting it on the bottom of the tank (completely submerged) or by setting it on a shelf in the tank that elevated it to variable depths determined by the experimental timeframe (Table S1). The monoliths were randomly assigned to either an elevated salinity or ambient salinity tank and to either completely submerged or drought-associated water depth.

Salinity was controlled by mixing water weekly to desired experimental salinity concentrations from four 2,000-gallon head tanks, 2 with freshwater and 2 with saltwater, and was pumped at a constant flow $\left(36-\mathrm{ml} \mathrm{min}^{-1}\right)$ into each mesocosm tank. Freshwater was collected from a nearby canal and had similar nutrient concentrations found in

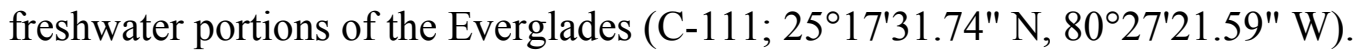
Saltwater head tanks were equipped with a pump to draw water from adjacent Florida Bay.

The monoliths were allowed to acclimate for 74 days under ambient salinity and completely inundated conditions before treatment manipulation and measurements began. At the commencement of the experiment, salinity was gradually raised from 10 to $20 \mathrm{ppt}$ in the elevated salinity tanks over a 2 -week period and maintained at $20 \mathrm{ppt}$ for the remainder of the experiment. The "drought" designated monoliths followed a scheduled regimen in which water level relative to the soil surface was manipulated (Table S1). The drought manipulation was designed to mimic water levels found at the monolith collection site during a drought year ${ }^{3}$. One week prior to each monthly sampling regime, the "drought" monoliths were raised or lowered to the corresponding height for that 
month (Table S1). The monoliths remained at that level until the next water level change. The four treatments were designated as: (1) Amb.Sub, (2) Amb.Exp, (3) Salt.Sub, (4) Salt.Exp, where the salinity treatment was defined as either ambient (Amb) (10 ppt) or elevated (Salt) (20 ppt), and the inundation treatment was defined as either completely submerged (Sub) (water $5 \mathrm{~cm}$ above soil) or subject to the soil surface being exposed because of drought (Exp) (water $20 \mathrm{~cm}$ below soil).

$\underline{\text { Soil } \mathrm{CO}_{2}}$ efflux. Prior to the beginning the experiment, one $10-\mathrm{cm}$ diameter PVC collar was installed 5-cm into the soil of each peat monolith for soil $\mathrm{CO}_{2}$ efflux measurements. Soil $\mathrm{CO}_{2}$ efflux was measured monthly for 120 seconds during the daytime on all 24 monoliths using a portable infrared gas analyzer (Li-Cor 8100, Lincoln, NE, USA) ${ }^{2}$.

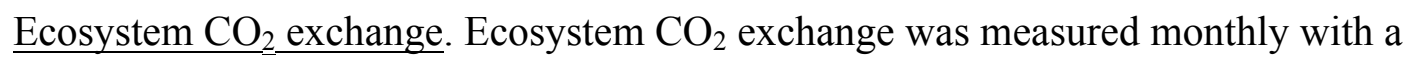
transparent static chamber $(53 \mathrm{~L}$ x $38 \mathrm{~W} \times 150 \mathrm{H} \mathrm{cm})$ placed over the monoliths and sealed $^{4-6}$. The chamber was equipped with two fans to circulate air. Carbon flux measurements were made in full light near solar noon and in the dark. After sealing the chamber, the system was allowed to equilibrate for 2 mins, after which change in $\mathrm{CO}_{2}$ concentration was recorded every second for 3 mins. During flux measurements, air was pumped from the chamber to a calibrated $\mathrm{CO}_{2} / \mathrm{H}_{2} \mathrm{O}$ gas analyzer (LI-COR model LI-840, Lincoln, NE, USA) placed in-line with the chamber. In between light and dark sampling, the chamber top was removed, allowing the chamber to equilibrate with atmospheric conditions. NEP was measured in full light, while ecosystem respiration of $\mathrm{CO}_{2}\left(\mathrm{ER}_{\mathrm{CO} 2}\right)$ 
was measured in the dark immediately after light measurements by covering the chamber with a dark cloth, blocking out all sunlight. GEP was calculated from NEP and $\mathrm{ER}_{\mathrm{CO} 2}$ as: $-G E P=-N E P-E R_{C O 2}$

where NEP is instantaneous $\mathrm{CO}_{2}$ flux $\left(\mu \mathrm{mol} \mathrm{m}{ }^{-2} \mathrm{~s}^{-1}\right)$ in light and $\mathrm{ER}_{\mathrm{CO} 2}$ is the $\mathrm{CO}_{2}$ flux in the dark. Daily integrated $\mathrm{CO}_{2}$ flux was modeled using previously established methods ${ }^{1}$.

Aboveground vegetation. Aboveground net primary productivity (ANPP) was measured non-destructively at bimonthly intervals following standard methods ${ }^{7}$. Briefly, each sawgrass culm was tagged and the number of live and dead leaves, shoot height, and culm diameter measured. Change in ANPP was calculated using previously derived allometric relationships between plant height, culm diameter, and biomass ${ }^{8}$.

Organic matter inputs and breakdown. Root growth was measured using the ingrowth core method ${ }^{9}$. One 1-mm nylon mesh bag (15-cm long, 3-cm diameter) filled with commercially available peat moss was inserted into the middle of each monolith after a core of the same size and depth was removed and was retrieved after one year. Living roots, those which floated to the surface when submerged in water, were separated from the peat material using a sieve and running water, dried at $60^{\circ} \mathrm{C}$ for one week, and weighed for biomass.

Root breakdown was measured on sawgrass roots. Sawgrass roots were collected at the same site as the monolith collection, washed, and dried at $60^{\circ} \mathrm{C}$ until weight stabilized. A weighed amount of root material was placed into a 1-mm 15-cm long nylon mesh bag that was sub-sectioned into $0-7.5-\mathrm{cm}$ and $7.5-15-\mathrm{cm}$ depths prior to inserting 
the root material. One decomposition bag was placed into each monolith and collected after one year. The roots were washed, dried at $60^{\circ} \mathrm{C}$, and weighed. Breakdown was calculated as the difference between the final mass and the initial mass. Leaf litter breakdown was measured similarly. Senescent sawgrass leaves were collected from the same site, dried, inserted into one 1-mm mesh bag per monolith, and placed on the soil surface. Litter bags were collected at the end of one year. The decomposed litter was rinsed, dried, and weighed.

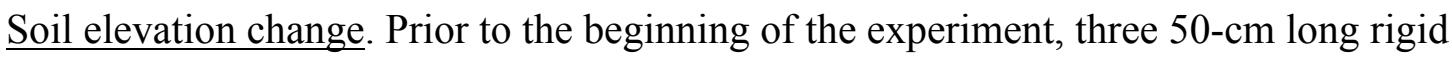
plastic rods were installed into each peat monolith down to the bottom of the bucket and labeled for repeated measurement. A reference soil surface height was recorded from the soil surface to the top of the rod. After the experiment began, the length from the soil surface to the top of each rod was recorded with a $40-\mathrm{cm}$ long ruler. Elevation change was calculated as the difference between the measured rod length and the reference height.

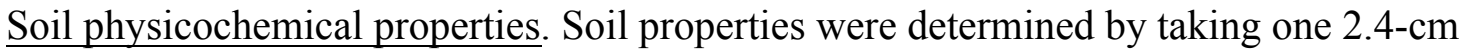
diameter core down to $30-\mathrm{cm}$. Samples were weighed immediately after collection and after one week of drying at $60^{\circ} \mathrm{C}$ to calculate percent water content. Dried samples were also weighed to calculate dry bulk density $\left(\mathrm{g} \mathrm{cm}^{-3}\right)$. The dried samples were subsequently ground, weighed, and analyzed for $\mathrm{C}, \mathrm{N}^{10}$, and $\mathrm{P}^{11}$ content. 
Historic water level. At the brackish water field site, we took water level measurements every 15 min between October 2014 and August 2017 (Aqua TROLL 200, In Situ, Inc., Fort Collins, CO). Water level retrieved from a long-term gauge (USGS EDEN, NP6) was calibrated to water depth at the brackish water site by regressing two years of on-site water level measurements to water level measured on the same day by the EDEN gauge $\left(\mathrm{BW}\right.$ water level $=1.104 * \mathrm{NP6}$ EDEN gauge $\left.+17.778, r^{2}=0.827\right)$. Water level at the BW site was then back-calculated back to 2001 using the equation above.

Field water collection. From October 2014 to August 2017, ambient surface water and porewater were collected monthly from the brackish water site that the monoliths for this experiment were extracted ${ }^{12}$. Briefly, porewater was collected via sippers installed $15-\mathrm{cm}$ into the soil. Porewater was extracted using a $140-\mathrm{mL}$ syringe by placing suction on an airstone via a piece of tubing. Surface water was collected via grab samples. Both porewater and surface water was immediately sampled in the field for salinity (YSI Model 600 XL, Yellow Springs, OH). Detailed methods can be found in Wilson et al. (in prep).

Statistical analyses. Statistical analysis was performed using R (R Core Team 2016). Linear mixed models (Package "nlme"13) were used to examine the relationships among C flux, aboveground biomass, culm density, and elevation and the independent variables of salinity, inundation, and time (fixed factors). All organic matter input and breakdown rates, as well as soil bulk density, percent water, organic matter, $\mathrm{C}, \mathrm{N}$, and $\mathrm{P}$ content, were determined using a two-way ANOVA with salinity and inundation as the fixed 
factors. Because of the split-plot, nested nature of our experimental design, each tank was set as a block (random factor), while inundation was nested within each block. All linear mixed models were assessed for temporal differences using the least squared means (LSMEANS), with date as a model effect (R package $l$ smeans ${ }^{14}$ ). All two-way ANOVAs were sub-tested with Tukey's post-hoc test to examine differences between treatments. Normality and homoscedasticity were tested by visually inspecting plotted residuals, and data was log-transformed in order to increase heteroscedasticity when necessary. Significance for all analyses was determined by an alpha level of 0.10 because of the nested nature of the design, the high variability between the monoliths, and the lack of available space to increase our replication power ${ }^{4}$.

\section{Supplementary Results}

\section{Gas flux and aboveground biomass}

Soil $\mathrm{CO}_{2}$ efflux from the saltwater-amended monoliths increased significantly $(1.69 \pm$ $\left.1.27 \mu \mathrm{mol} \mathrm{m} \mathrm{m}^{-2} \mathrm{~s}^{-1}\right)$ compared to the ambient salinity monoliths $\left(0.35 \pm 0.29 \mu \mathrm{mol} \mathrm{m} \mathrm{m}^{-2} \mathrm{~s}^{-1}\right)$ after salinity was initially raised from 10 to $15 \mathrm{ppt}$ (LSMEANS, $t=-4.17, P=0.014$ ), but this effect diminished during the next month (Dec 2016) after salinity was raised from 15 to $20 \mathrm{ppt}$ (LSMEANS, $t=0.26, P=0.807$; Fig. S1). Overall, elevated salinity had no significant effect on soil $\mathrm{CO}_{2}$ efflux (Table S2). Drought caused significantly higher soil $\mathrm{CO}_{2}$ efflux compared to the inundated monoliths, but there was no interacting effect of elevated salinity and drought (Table S2). When water was raised back to above the soil surface (Aug 2017), there was no difference in soil $\mathrm{CO}_{2}$ efflux between the inundated and drought monoliths (LSMEANS, $t=-0.02, P=0.978$; Fig. S1). 
Across the sampling year, short-term GEP rates ranged from $2.0 \mu \mathrm{mol} \mathrm{m} \mathrm{m}^{-2} \mathrm{~s}^{-1}$ (median for Salt.Exp in May 2017) to $11.2 \mu \mathrm{mol} \mathrm{m} \mathrm{m}^{-2} \mathrm{~s}^{-1}$ (median for Amb.Exp in Apr 2017; Fig. S2a). Rates of GEP were significantly lower with elevated salinity (Tables S2, S3). There was a significant effect of drought on GEP, however, this was only significant when comparing the ambient salinity monoliths, not the elevated salinity monoliths (Tables S2, S3). There was a large drop in GEP during the height of the drought (MayJun) for the Amb.Exp monoliths (Fig. S2a).

Rates of $\mathrm{ER}_{\mathrm{CO} 2}$ ranged from $0.9 \mu \mathrm{mol} \mathrm{m} \mathrm{m}^{-2}$ (median for Salt.Sub in Sep 2017) to $6.9 \mu \mathrm{mol} \mathrm{m} \mathrm{m}^{-2}$ (median for Amb.Exp in Apr 2017; Fig. S2b) and were significantly affected by both elevated salinity and drought (Table S2). Elevated salinity reduced mean $\mathrm{ER}_{\mathrm{CO} 2}$ in both the submerged and drought monoliths, while drought significantly increased $\mathrm{ER}_{\mathrm{CO} 2}$ (Table S3). Based on the difference between soil $\mathrm{CO}_{2}$ efflux and $\mathrm{ER}_{\mathrm{CO} 2}$, plant respiration accounted for $80 \%, 74 \%, 79 \%$, and $68 \%$ of total respiration for the Amb.Sub, Amb.Exp, Salt.Sub, and Salt.Exp monoliths, respectively.

Rates of NEP ranged from $-2.7 \mu \mathrm{mol} \mathrm{m} \mathrm{m}^{-2} \mathrm{~s}^{-1}$ (median for Salt.Exp in May 2017) to $8.8 \mu \mathrm{mol} \mathrm{m} \mathrm{s}^{-2}$ (median for Amb.Exp in Nov 2016; Fig. S2c). Despite much lower mean rates (Table S3), elevated salinity did not significantly affect NEP (Table S2). During the warmest part of the year (summer 2017), all the elevated salinity monoliths shifted from a net $\mathrm{CO}_{2}$ sink to a net $\mathrm{CO}_{2}$ source, with drought accelerating $\mathrm{CO}_{2}$ loss from the marsh (Fig. S2c). Overall, drought did not affect NEP; however, there was an inundation by time effect (Table S2).

Modeled GEP strongly reflected the patterns seen with instantaneous GEP (Fig. S3a). Elevated salinity strongly suppressed GEP, while inundation level had no effect 
(Table S2). Modeled ER $\mathrm{CO}_{\mathrm{C} 2}$ was enhanced with drought and suppressed with elevated salinity (Fig. S3b). Neither elevated salinity nor drought alone significantly affected modeled NEP, but there was a strong salinity by inundation effect (Table S2). When comparing the submerged treatments, elevated salinity caused significantly more $\mathrm{C}$ to be released to the atmosphere (Table 1). Under drought conditions, plant respiration (taken as the difference between soil $\mathrm{CO}_{2}$ efflux and $\mathrm{ER}_{\mathrm{CO} 2}$ ) increased by $706 \mathrm{~g} \mathrm{C} \mathrm{m}^{-2} \mathrm{yr}^{-1}$ with ambient salinity and only by $166 \mathrm{~g} \mathrm{C} \mathrm{m}^{-2} \mathrm{yr}^{-1}$ with elevated salinity. This resulted in no calculated difference in modeled NEP between the ambient and elevated salinity treatments when experiencing drought (Table 1).

Aboveground biomass $\left(\mathrm{g} \mathrm{C} \mathrm{m}^{-2}\right)$ at the conclusion of the experiment was $140.1 \pm$ $11.2,184.0 \pm 36.7,73.1 \pm 25.7$, and $147.3 \pm 17.1$ in the Amb.Sub, Amb.Exp, Salt.Sub, and Salt.Exp treatments, respectively. Elevated salinity led to significantly less biomass, while drought had no effect (Table S2). Culm density within the ambient salinity monoliths increased from $4.0 \pm 0.5$ and $4.7 \pm 1.0$ culms plot $^{-1}$ at the beginning of the

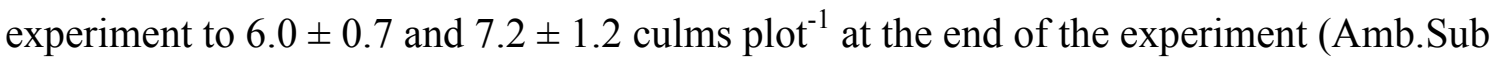
and Amb.Exp, respectively). Culm density within the elevated salinity monoliths remained relatively unchanged from the beginning $\left(4.3 \pm 0.8\right.$ and $7.2 \pm 1.0$ culms plot $\left.^{-1}\right)$ to the end of the experiment $\left(3.0 \pm 1.0\right.$ and $7.8 \pm 1.3$ culms plot $^{-1}$; Salt.Sub and Salt.Exp, respectively). Culm density was not influenced by either elevated salinity or drought (Table S2). Rate of ANPP was also not affected by elevated salinity or drought (Table 1, $\mathrm{S} 2)$. 


\section{Organic matter inputs and breakdown}

We summarized organic matter inputs and breakdown in Table 1. Elevated salinity slowed decomposition in both the top $7.5-\mathrm{cm}$ of soil $\left(F_{(1,19)}=5.29, P=0.032\right)$ and 7.5-15-cm depth $\left(F_{(1,19)}=5.43, P=0.031\right)$. Inundation accelerated breakdown in the 7.515-cm depth horizon $\left(F_{(1,19)}=7.65, P=0.012\right)$ but had no effect in the top 7.5-cm of soil $\left(F_{(1,19)}=0.28, P=0.599\right)$. Both elevated salinity $\left(F_{(1,15)}=8.70, P=0.009\right)$ and increased soil exposure $\left(F_{(1,15)}=65.86, P<0.001\right)$ significantly slowed leaf decomposition. Elevated salinity significantly reduced live root biomass measured at the end of the experiment $\left(F_{(1,19)}=36.52, P<0.001\right)$, but inundation did not have any effect $\left(F_{(1,19)}=0.181, P=\right.$ 0.639). Elevated salinity significantly reduced root ingrowth $\left(F_{(1,120)}=9.29, P=0.006\right)$, but inundation did not have any effect $\left(F_{(1,20)}=1.47, P=0.239\right)$. At the end of the experiment, live root biomass in soil down to 25 -cm was $68.6 \pm 18.2,107.5 \pm 27.8,12.0$ \pm 7.7 , and $26.6 \pm 7.9 \mathrm{~g} \mathrm{C} \mathrm{m}^{-2}$ in the Amb.Sub, Amb.Exp, Salt.Sub, and Salt.Exp treatments, respectively. Elevated salinity significantly reduced live root biomass found at the end of the experiment $\left(F_{(1,19)}=36.52, P<0.001\right)$, but inundation did not have any $\operatorname{effect}\left(F_{(1,19)}=0.181, P=0.639\right)$.

\section{Soil properties}

At the end of the experiment, there was no difference in soil bulk density and percent water among treatments (Table S4). Soil organic matter $\left(F_{(1,19)}=17.69, P<\right.$ $0.001), \mathrm{C}\left(F_{(1,19)}=12.92, P=0.002\right)$, and $\mathrm{N}\left(F_{(1,19)}=6.77, P=0.017\right)$ content were all lower with elevated salinity (Table S4). Inundation had no effect on soil organic matter 
$\left(F_{(1,19)}=0.11, P=0.737\right), \mathrm{C}\left(F_{(1,19)}=0.03, P=0.846\right)$, and $\mathrm{N}\left(F_{(1,19)}=0.30, P=0.501\right)$

content.

\section{Elevation change}

Over the duration of the experiment, soil elevation change was not affected by elevated salinity, but drought significantly increased elevation loss (Table S2). Elevation loss occurred in both the ambient and elevated salinity monoliths (Fig. 5). Over the duration of the experiment, the monoliths lost $2.9 \pm 0.4,3.7 \pm 0.4,3.0 \pm 0.6$, and $4.4 \pm 0.8$ cm of elevation from the Amb.Sub, Amb.Exp, Salt.Sub, and Salt.Exp treatments, respectively.

\section{Literature Cited}

1 Wilson, B. J. et al. Declines in plant productivity drive carbon loss from coastal wetland mesocosms exposed to saltwater intrusion. Global Change Biology (In Review).

2 Chambers, L. G. et al. Biogeochemical effects of simulated sea level rise on carbon loss in an Everglades mangrove peat soil. Hydrobiologia, doi 10.1007/s10750-10013-11764-10756 (2013).

3 Wilson, B. J. et al. Salinity pulses in brackish and freshwater marshes interact with seasonal dry-down to increase ecosystem carbon loss in the Florida Coastal Everglades. Ecological Applications (In Prep).

4 Neubauer, S. C. Ecosystem responses of a tidal freshwater marsh experiencing saltwater intrusion and altered hydrology. Estuaries and Coasts 36, 491-507, doi:10.1007/s12237-011-9455-x (2013).

5 Weston, N. B., Neubauer, S. C., Velinsky, D. J. \& Vile, M. A. Net ecosystem carbon exchange and the greenhouse gas balance of tidal marshes along an estuarine salinity gradient. Biogeochemistry 120, 163-189 (2014). 
6 Wilson, B. J., Mortazavi, B. \& Kiene, R. P. Spatial and temporal variability in carbon dioxide and methane exchange at three coastal marshes along a salinity gradient in a northern Gulf of Mexico estuary. Biogeochemistry 123, 329-347, doi:10.1007/s10533-015-0085-4 (2015).

7 Daoust, R. J. \& Childers, D. L. Quantifying aboveground biomass and estimating net aboveground primary production for wetland macrophytes using a nondestructive phenometric technique. Aquatic Botany 62, 115-133, doi:10.1016/s0304-3770(98)00078-3 (1998).

8 Childers, D. L. et al. Responses of sawgrass and spikerush to variation in hydrologic drivers and salinity in Southern Everglades marshes. Hydrobiologia 569, 273-292, doi:10.1007/s10750-006-0137-9 (2006).

9 Vogt, K. A., Vogt, D. J. \& Bloomfield, J. Analysis of some direct and indirect methods for estimating root biomass and production of forests at an ecosystem level. Plant and Soil 200, 71-89, doi:10.1023/a:1004313515294 (1998).

10 Zimmermann, C. F. \& Keefe, C. W. Method 440.0. Determination of carbon and nitrogen in sediments and particulates of estuarine/coastal waters using elemental analysis. (U.S. Environmental Protection Agency, National Exposure Research Laboratory, Office of Research and Development, 1997).

11 Solorzano, L. \& Sharp, J. H. Determination of total dissolved phosphorus and particulate phosphorus in natural-waters. Limnology and Oceanography 25, 754757 (1980).

12 Wilson, B. J. et al. Balancing nutrient subsidy and salinity stress: short- and longterm effects of saltwater intrusion on freshwater wetland ecosystem functions. Ecology (In Prep).

13 Pinheiro, J., Bates, D., DebRoy, S., Sarkar, D. \& Team, R. C. nlme: Linear and Nonlinear Mixed Effects Models. https://cran.r-project.org/package=nlme (2017).

14 Lenth, R. V. Using lsmeans. https://cran.rproject.org/web/packages/lsmeans/vignettes/using-lsmeans.pdf (2017). 


\section{CONCLUSION}

Coastal wetlands and their capacity to store large amounts of carbon $(\mathrm{C})$ in their soils, are threatened as a result of sea level rise (SLR). Sea level rise will cause saltwater to intrude into marshes, generating several forcing factors including: elevated salinity, greater inundation, and increased nutrients, that all have the potential to affect ecosystem structure and function. In coastal peat marshes such as the Everglades, even small changes in water chemistry or hydroperiod can substantially change the soil $\mathrm{C}$ balance and influence peat collapse. Here, I tested how saltwater intrusion would influence ecosystem structure and function within coastal wetlands, and how changes in ecosystem structure and function influenced peat collapse.

In chapter I, I show that 2 years of monthly pulses of saltwater produced contrasting results that depended on the initial salinity of the marsh. In the freshwater (FW) marsh, elevated salinity ( $\sim 5 \mathrm{ppt})$ did not affect net ecosystem productivity (NEP) but did result in a decline in plant species richness and a decline in live roots found in the soil. At the brackish water (BW) site (ambient salinity $\sim 10 \mathrm{ppt}$ ), I found no effects of elevated pulsed salinity ( $20 \mathrm{ppt})$ on NEP when the marsh was inundated. However, when water fell below the soil surface, the BW marsh shifted from a $\mathrm{C}$ sink to a $\mathrm{C}$ source, and elevated salinity enhanced $\mathrm{CO}_{2}$ efflux from the marsh by 3.6 times. In addition, there was a large loss of live roots in the soil with elevated salinity. Within the control plots, the BW site had significantly fewer live roots in the soil compared to the FW site.

In chapters II-IV, I used mesocosm experiments to test the press effects of saltwater intrusion in FW and BW marshes. In chapter II, I tested the effects of elevated salinity ( 10 ppt) and increased phosphorus (P) loading in a FW marsh. Elevated salinity 
alone had no effect on ecosystem productivity but led to a loss of live root. Elevated P alone significantly increased ecosystem productivity but had no effect on root growth. Because of this, plant biomass allocation shifted towards greater aboveground to belowground biomass. Combined, the effects of elevated salinity and P on ecosystem productivity changed temporally. Overall, elevated $\mathrm{P}$ had a greater subsidy effect on productivity than the stress effect of elevated salinity. However, elevated salinity began to have an inhibitory effect on ecosystem productivity after two years of continual exposure.

In chapter III, after finding that raising salinity to $\sim 10 \mathrm{ppt}$ in a FW marsh had no effect on ecosystem productivity (chapter II), I conducted a mesocosm experiment in which I raised salinity in monoliths from a BW marsh from $\sim 10 \mathrm{ppt}$ (ambient) to $20 \mathrm{ppt}$ and subjected the monoliths to different inundation levels [submerged vs. exposed (water level 4-cm below soil surface)], to see if this would affect ecosystem productivity. Net ecosystem productivity declined by up to 9 times with elevated salinity, while more inundation had no effect on NEP. Soil $\mathrm{CO}_{2}$ efflux was unaffected by elevated salinity and decreased with more inundation.

Finally, in chapter IV, based on results from the field data that showed that NEP was only affected by elevated salinity when water fell below the soil surface during drought (chapter I), I conducted a mesocosm experiment to test the combined effect of elevated salinity and drought on a BW marsh. Like chapter III, elevated salinity led to a significant decrease in NEP. Drought significantly increased soil $\mathrm{CO}_{2}$ efflux. Under ambient salinity conditions ( $\sim 10 \mathrm{ppt})$, I found a $2.9 \pm 0.4 \mathrm{~cm}$ decrease in soil elevation after only one year, while elevating salinity did not significantly affect elevation loss. 
Additionally, I measured elevation loss of $4.4 \pm 0.8 \mathrm{~cm}$ after one year with combined elevated salinity and drought.

Given these findings, I can suggest hypotheses for the drivers and mechanisms of peat collapse. When freshwater marshes are first exposed to elevated salinity, aboveground productivity and NEP may be unaffected by elevated salinity and may actually increase with initial P exposure. Soil structure and integrity, however, are negatively affected by salt through a loss of live roots within the soil profile, leaving the peat vulnerable to collapse. This scenario explains the presence of live sawgrass "pedestals" in the brackish portions of the Everglades, where it appears that the surrounding soil has collapsed despite highly productive sawgrass plants. In fact, I found that soils within the BW portions of the Everglades may be experiencing a large rate $(\sim 3$

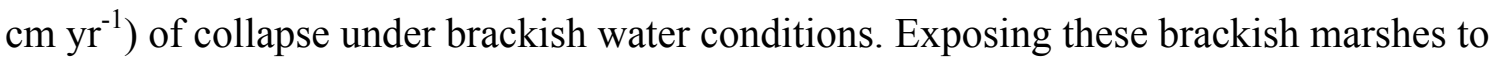
even greater increases in salinity further led to a net decline in soil C storage through reductions in NEP and root growth, but did not negatively affect elevation. Seasonal drydown was a strong driver of elevation loss $\left(\sim 4.4 \mathrm{~cm} \mathrm{yr}^{-1}\right)$ within BW soils and further exacerbated the peat collapse.

Although saltwater intrusion into freshwater wetlands may initially stimulate primary productivity through a P subsidy, the impact of elevated salinity on root and soil structure may ultimately be what matters to the survival or collapse of coastal peat marshes. Because seasonal dry-down can accelerate peat collapse, the restoration of flow regimes to the coastal Everglades has the potential to mitigate peat collapse. Increased water flows can mitigate peat collapse in two ways. First, enhanced freshwater delivery to coastal areas recharges aquifers and creates a stronger freshwater head that helps hold 
back saltwater intrusion (Koch et al. 2015, Dessu et al. 2018). Second, longer periods of inundation, even with brackish water, can prevent strong, seasonal dry-down events from occurring (Sklar et al. 2001). This would greatly reduce groundwater intrusion of marine water into coastal marshes and prevent the acceleration of peat collapse. While it is unlikely that these marshes will ever recover to pre-collapsed conditions in the near future, enhanced water delivery has the potential to slow down collapse and allow for the recruitment and establishment of mangroves that help stabilize the soil (Jiang et al. 2014). However, given accelerating SLR and delays in the implementation of Comprehensive Everglades Restoration Plan projects, further collapse of peat marshes within the coastal Everglades can be expected. Understanding the drivers and mechanisms behind this collapse is urgently needed to inform management practices aimed at preventing peat collapse and the transformation of marsh habitat to open water ponds in the Everglades and other coastal peatlands (Delaune et al. 1994, Cahoon et al. 2003, Deegan et al. 2012).

\section{LITERATURE CITED}

Cahoon, D. R., P. Hensel, J. Rybczyk, K. L. McKee, C. E. Proffitt, and B. C. Perez. 2003. Mass tree mortality leads to mangrove peat collapse at Bay Islands, Honduras after Hurricane Mitch. Journal of Ecology 91:1093-1105.

Deegan, L. A., D. S. Johnson, R. S. Warren, B. J. Peterson, J. W. Fleeger, S. Fagherazzi, and W. M. Wollheim. 2012. Coastal eutrophication as a driver of salt marsh loss. Nature 490:388-+.

Delaune, R. D., J. A. Nyman, and W. H. Patrick. 1994. Peat collapse, ponding and wetland loss in a rapidly submerging coastal marsh. Journal of Coastal Research 10:1021-1030.

Dessu, S. B., R. M. Price, T. G. Troxler, and J. S. Kominoski. 2018. Effects of sea-level rise and freshwater management on long-term water levels and water quality in the Florida Coastal Everglades. Journal of Environmental Management In Press. 
Jiang, J., D. L. DeAngelis, G. H. Anderson, and T. J. Smith. 2014. Analysis and Simulation of Propagule Dispersal and Salinity Intrusion from Storm Surge on the Movement of a Marsh-Mangrove Ecotone in South Florida. Estuaries and Coasts 37:24-35.

Koch, M. S., C. Coronado, M. W. Miller, D. T. Rudnick, E. Stabenau, R. B. Halley, and F. H. Sklar. 2015. Climate Change Projected Effects on Coastal Foundation Communities of the Greater Everglades Using a 2060 Scenario: Need for a New Management Paradigm. Environmental Management 55:857-875.

Sklar, F. H., H. C. Fitz, Y. Wu, R. Van Zee, and C. McVoy. 2001. The design of ecological landscape models for Everglades restoration. Ecological Economics 37:379-401. 
VITA

\section{BENJAMIN J. WILSON}

Born, Omaha, Nebraska

2011

B.S., Biological Sciences

University of Alabama

Tuscaloosa, AL

2013

M.S., Marine Biology

University of Alabama

Dauphin Island Sea Lab

Dauphin Island, AL

2014-2016

2014-2015

2016-2018

2016

2016

2016

2017

2018

2017

2017

2017

2018
President, Biology Graduate Student Association - Florida International University

Science Communication Fellow - Philip and Patricia Frost Science Museum, Miami, FL

Policy Coordinator, Student Workshops on Acidification and Greenhouse Gases - Florida International University

$2^{\text {nd }}$ place Student poster - Florida Coastal Everglades LTER meeting Florida Coastal Everglades LTER Student of the Year $3^{\text {rd }}$ place student poster - Florida International University graduate scholarly forum $2^{\text {nd }}$ place student oral presentation - FIU graduate scholarly forum

$1^{\text {st }}$ place student oral presentation - FIU Biology Department Symposium

Coastal \& Estuarine Research Federation travel award, $\underline{\$ 300}$

National Science Foundation Doctoral Dissertation Improvement Grant. DISSERTATION RESEARCH: How do saltwater intrusion and drought interact to change the soil carbon balance of a brackish water coastal marsh? $\$ 19,045$

Florida International University Dissertation Year Fellowship. $\underline{\$ 16,600}$

Ph.D., Biology

Florida International University Miami, FL 


\section{SELECTED PUBLICATIONS AND PRESENTATIONS}

Hu, M., Wilson, B.J., Sun, Z., Ren, P, and Tong, C. (2017). Effects of the addition of nitrogen and sulfate on $\mathrm{CH}_{4}$ and $\mathrm{CO}_{2}$ emissions, soil, and pore water chemistry in a high marsh of the Min River estuary in southeastern China. Science of the Total Environment. 597: 292:304. https://doi.org/10.1016/j.scitotenv.2016.11.103

Hu, M., Ren, H., Wilson, B.J., Li, J., Tong, C., and Ren, P. (2017). Responses of gaseous carbon emission to low-level salinity increase in tidal marsh ecosystem of the Min River estuary, southeastern China. Journal of Environmental Sciences 52: 210-222. https://doi.org/10.1016/j.jes.2016.05.009

Wilson, B.J., Mortazavi, B, Kiene, R.P. (2015). Spatial and temporal variability in methane and carbon dioxide exchange at three coastal marshes along a salinity gradient in a northern Gulf of Mexico estuary. Biogeochemistry 123(3): 329-347.

https://doi.org/10.1007/s10533-015-0085-4

Mortazavi, B., Wilson, B.J., Bauer, D.S., Feng, D. Gupta, M. (2013). Validation and application of cavity-enhanced, near-infrared tunable diode laser absorption spectrometry for measurements of methane carbon isotopes at ambient concentrations. Environmental Science \& Technology. 47(20): 11676-11684. https://doi.org/10.1021/es402322x

Wilson, B.J., Troxler, T.G., et al. 2018. Saltwater intrusion and drought drive peat collapse in a brackish coastal peatland. Florida International University Biology Department Symposium, Miami, FL. * $1^{\text {st }}$ place*

Wilson, B.J. and Troxler, T.G. 2017. Saltwater intrusion coupled with drought accelerates carbon loss from a brackish coastal wetland. American Geophysical Union, New Orleans, LA.

Wilson, B.J., Servais, S. et al. 2017. Biogeochemical effects of a freshwater marsh experiencing simultaneous saltwater intrusion and nutrient enrichment: A stress-subsidy experiment. Ecological Society of America, Portland, OR.

Wilson, B.J., Servais, S. et al. 2017. Changes in Everglades carbon cycling in the face of sea level rise: press vs. pulse responses. Society for Wetland Scientists, San Juan, Puerto Rico.

Wilson, B.J., Servais, S. et al. 2016. Simulated saltwater intrusion decreases net ecosystem exchange in coastal marshes, dampening their capacity to store carbon. Ecological Society of America, Fort Lauderdale, FL.

Wilson, B.J., Servais, S. et al. 2016. Biogeochemical and physiological effects of simulated sea level rise in the coastal Florida Everglades. Association for the Sciences of Limnology and Oceanography, Santa Fe, NM. 